\title{
Mechanism-Based Design of an Amide-Directed Ni-Catalyzed Arylboration of Cyclopentene Derivatives
}

Alison L. Lambright, Yanyao Liu, Isaac A. Joyner, Kaitlyn M. Logan, M. Kevin Brown* Department of Chemistry, Indiana University, 800 E. Kirkwood Ave, Bloomington, IN 47405

\section{Supporting Information}

\section{Contents}

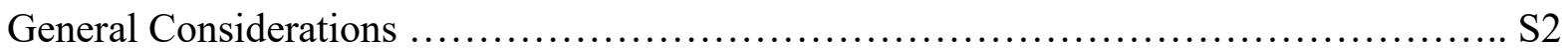

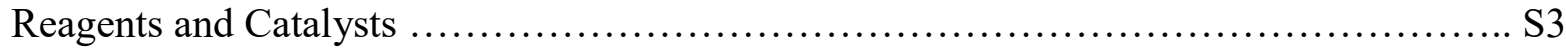

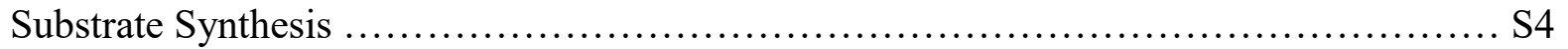

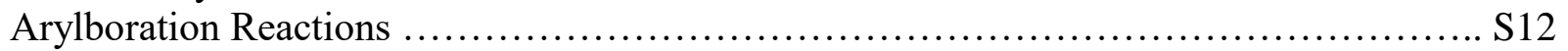

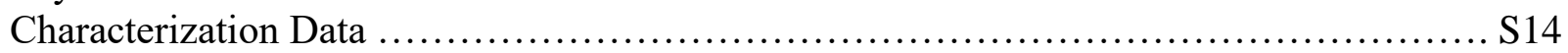

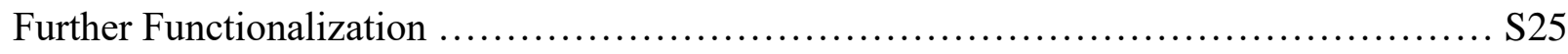

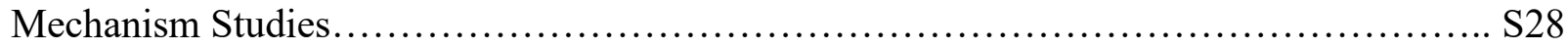

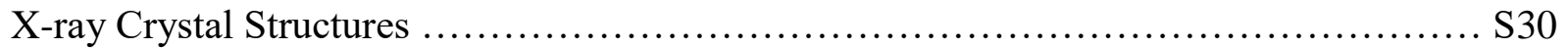

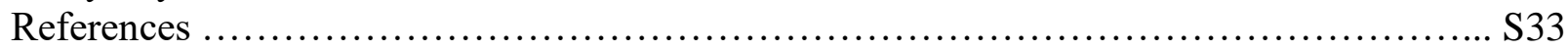

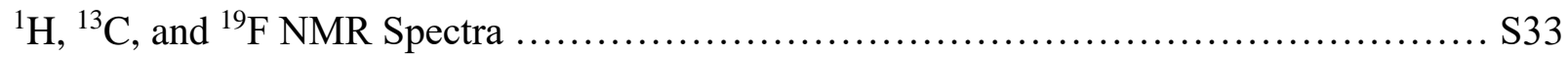


General Considerations: Infrared (IR) spectra were recorded on a Bruker Tensor II FTIR Spectrometer, $v_{\max }$ in $\mathrm{cm}^{-1}$. Bands are characterized as broad (br), strong (s), medium (m), and weak (w). ${ }^{1} \mathrm{H}$ NMR spectra were recorded at room temperature unless otherwise noted on a Varian I400 (400 MHz), Varian VXR400 (400 MHz), Varian I500 (500 MHz), or a Varian I600 (600 $\mathrm{MHz}$ ) spectrometer. Chemical shifts are reported in ppm from tetramethylsilane with the residual solvent resonance as the internal standard $\left(\mathrm{CHCl}_{3}: \delta 7.26 \mathrm{ppm}\right)$. Data are reported as follows: chemical shift, multiplicity $(\mathrm{s}=$ singlet, $\mathrm{d}=$ doublet, $\mathrm{t}=$ triplet, $\mathrm{q}=$ quartet, $\mathrm{br}=$ broad, $\mathrm{m}=$ multiplet), coupling constants (Hz), and integration. ${ }^{13} \mathrm{C}$ NMR spectra were recorded on a Varian I400 (100 MHz), Varian VXR400 (100 MHz), Varian I500 (125 MHz), or a Varian I600 (150 $\mathrm{MHz}$ ) spectrometer with complete proton decoupling. Chemical shifts are reported in ppm from tetramethylsilane with the solvent resonance as the internal standard $\left(\mathrm{CDCl}_{3}: \delta 77.16 \mathrm{ppm}\right) .{ }^{19} \mathrm{~F}$ NMR spectra were recorded on Varian VXR400 (375 MHz) spectrometer. High Resolution Mass Spectrometry (HRMS) analysis was obtained using Electron Impact Ionization (EI), Chemical Ionization (CI), Atmospheric Pressure Chemical Ionization (APCI) or Electrospray Ionization (ESI) and reported as $\mathrm{m} / \mathrm{z}$ (relative intensity). ESI was acquired using a Waters/Micromass LCT Classic (ESI-TOF). The diastereomeric and regioisomeric ratios were determined using NMR or GC analysis of unpurified reaction mixtures. GC analyses were performed by means of Agilent 6850 Gas Chromatograph equipped with Agilent 19091Z-413E, $30 \mathrm{~m}$ x $320 \mu \mathrm{m}$ x $0.25 \mu \mathrm{m}$ column. Helium was used as the GC carrier gas and maintained at a constant flow rate of $25.0 \mathrm{~mL} / \mathrm{min}$. The capillary column was held for 1.0 minutes at the initial temperature $\left(60{ }^{\circ} \mathrm{C}\right)$ and subsequently ramped at a rate of $25^{\circ} \mathrm{C} / \mathrm{min}$ to a final temperature of $300^{\circ} \mathrm{C}$. Total run time was $9.60 \mathrm{~min}$. Unless otherwise noted, all reactions have been carried out with distilled and degassed solvents under an atmosphere of dry $\mathrm{N}_{2}$ in oven- $\left(150{ }^{\circ} \mathrm{C}\right)$ or flame-dried glassware with standard vacuumline techniques. Dichloromethane (DCM), tetrahydrofuran (THF), diethyl ether $\left(\mathrm{Et}_{2} \mathrm{O}\right)$, dioxane and dimethylformamide (DMF) were purified under a positive pressure of dry argon by passage through two columns of activated alumina. Toluene ( $\mathrm{PhMe}$ ) was purified under a positive pressure of dry argon by passage through columns of activated alumina and Q5 (Grubbs apparatus). All work-up and purification procedures were carried out with reagent grade solvents (purchased from Sigma-Aldrich) in air. Standard column chromatography techniques using ZEOprep 60/40-63 $\mu \mathrm{m}$ silica gel or a CombiFlash Rf 150 with pre-packed silica cartridges were used for purification. 
- Reagents and Catalysts

Allylbromide was purchased from Sigma Aldrich and used as received.

Benzylamine was purchased from Fluka and used as received.

Bis(pinacolato)diboron was purchased from Oakwood Chemical and recrystallized in pentane prior to use.

Bromobenzene was purchased from Sigma Aldrich and purified via neat filtration through a $2 \mathrm{~cm}$ pad of dry silica in a 5.75-inch pipet prior to use.

a-(Bromomethyl)styrene was synthesized in accordance with literature procedure. ${ }^{1}$

4-Bromoanisol was purchased from Combi-Blocks and purified via neat filtration through a $2 \mathrm{~cm}$ pad of dry silica in a 5.75-inch pipet prior to use.

4-(4-bromobenzyl)morpholine was synthesized in accordance with literature procedure. ${ }^{2}$

1-Bromo-4-chlorobenzene was purchased from Sigma Aldrich and recrystallized in pentane prior to use.

4-Bromofluorobenzene was purchased from TCI Chemicals and purified via neat filtration through a $2 \mathrm{~cm}$ pad of dry silica in a 5.75 -inch pipet prior to use.

3-bromofuran was purchased from Combi-Blocks and purified via neat filtration through a $2 \mathrm{~cm}$ pad of dry silica in a 5.75-inch pipet prior to use.

5-Bromo-2-methoxypyridine was purchased from Combi-Blocks and purified via neat filtration through a $2 \mathrm{~cm}$ pad of dry silica in a 5.75 -inch pipet prior to use.

5-Bromo-1-methyl-1H-indole was synthesized in accordance with literature procedure. ${ }^{3}$

1-Bromo-2-methylprop-1-ene was purchased from Combi-Blocks and purified via neat filtration through a $2 \mathrm{~cm}$ pad of dry silica in a 5.75 -inch pipet prior to use.

1-Bromonaphthalene was purchased from Oakwood Chemical and purified via neat filtration through a $2 \mathrm{~cm}$ pad of dry silica in a 5.75-inch pipet prior to use.

2-Bromoprop-1-ene was purchased from Oakwood Chemical and purified via neat filtration through a $2 \mathrm{~cm}$ pad of dry silica in a 5.75-inch pipet prior to use.

2-Bromotoluene was purchased from Oakwood Chemical and purified via neat filtration through a $2 \mathrm{~cm}$ pad of dry silica in a 5.75-inch pipet prior to use.

3-Chloro- $N$-methylaniline was purchased from TCI Chemicals and was distilled on a Kugelröhr distillation apparatus before use.

Citric acid was purchased from Oakwood Chemical and used as received.

Cyclohex-3-ene-1-carboxylic acid was purchased from Oakwood Chemical and used as received. Cyclopent-3-ene-1-carboxylic acid was purchased from Combi-Blocks and used as received.

Dibromomethane was purchased from Alfa Aesar and purified via neat filtration through a $2 \mathrm{~cm}$ pad of dry silica in a 5.75-inch pipet prior to use.

Diethyl allylmalonate was purchased from Alfa Aesar and used as received.

Diisobutylaluminium hydride (1.0 M in hexanes) was purchased from Sigma Aldrich and used as received.

Diisopropylamine was purchased from Sigma Aldrich and distilled over calcium hydride immediately prior to use.

Dimethylamine hydrochloride solution ( 2 M in THF) was purchased from Sigma Aldrich and used as received.

4-Dimethylaminopyridine was purchased from Oakwood Chemical and used as received.

1-Ethyl-3-(3-dimethylaminopropyl)carbodiimide was purchased from AK Scientific and used as received. 
Hydrogen peroxide solution (30\% in water) was purchased from Macron Chemicals and used as received.

Indoline was purchased from Sigma Aldrich and used as received.

4-Methoxy- $N$-methylaniline was purchased from Combi-Blocks and was distilled on a Kugelröhr distillation apparatus before use.

1-Methylcyclopent-3-ene-1-carboxylic acid was synthesized in accordance with literature procedure. $^{4}$

3-Methylcyclopent-3-ene-1-carboxylic acid was synthesized in accordance with literature procedure. $^{4}$

n-Butyllithium solution (2.5 M in hexanes) was purchased from Sigma Aldrich and titrated before use.

Nickel (II) chloride, dimethoxyethane adduct was purchased from Strem Chemicals and used as received.

N,2-Dimethylaniline was purchased from Combi-Blocks and was distilled on a Kugelröhr distillation apparatus before use.

$N$-Ethylaniline was purchased from Combi-Blocks and was distilled on a Kugelröhr distillation apparatus before use.

$N$-Methylaniline was purchased from Combi-Blocks and was distilled on a Kugelröhr distillation apparatus before use.

N,N-Dimethylacetamide (DMA) was purchased from Sigma Aldrich in a Sure-Seal ${ }^{\text {TM }}$ bottle and used as received.

$\boldsymbol{N}, \boldsymbol{O}$-Dimethylhydroxylamine hydrochloride was purchased from Oakwood Chemical and used as received.

1-Phenylpyrrolidin-2-one was purchased from Combi-Blocks and used as received.

Potassium hydroxide was purchased from Macron Chemicals and used as received.

Potassium tert-butoxide was purchased from Strem Chemicals and used as received.

Sodium hydride (60 wt\% in mineral oil) was purchased from Sigma Aldrich and used as received.

Sodium tert-butoxide was purchased from Strem Chemicals and used as received.

Sodium thiosulfate was purchased from Oakwood Chemical and used as received.

tert-Butyl (4-bromophenyl)(methyl)carbamate was synthesized in accordance with literature procedure. 5

tert-Butyllithium (2.5 $\mathrm{M}$ in pentane) was purchased from Sigma Aldrich and titrated before use. 1,3,5-Trimethylbenzene was purchased from Sigma-Aldrich and purified via column chromatography (100\% pentane) and stored over activated $4 \AA$ molecular sieves.

Zhan-1B catalyst was purchased from Strem Chemicals and used as received.

\section{Substrate Synthesis}

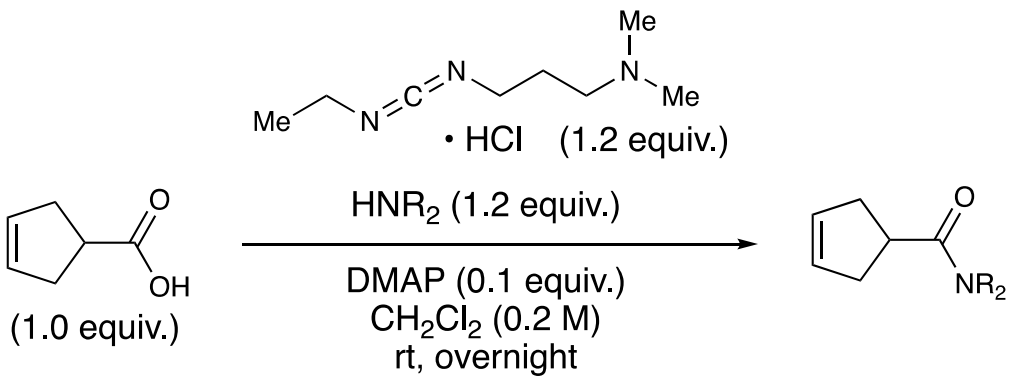




\section{General Procedure A: Amidation}

To a flame-dried round-bottom flask equipped with a stir bar was added 4-dimethylaminopyridine (0.1 equiv) and 1-ethyl-3-(3-dimethylaminopropyl)carbodiimide (1.2 equiv). The flask was evacuated/backfilled with $\mathrm{N}_{2}(3 \mathrm{x})$ and $\mathrm{CH}_{2} \mathrm{Cl}_{2}(0.2 \mathrm{M})$, carboxylic acid (1.0 equiv), and amine (1.2 equiv) were added. After stirring at room temperature overnight, the reaction was quenched with citric acid $\left(0.08 \mathrm{M}\right.$ in $\left.\mathrm{H}_{2} \mathrm{O}\right)$. The organic layers were collected and washed with citric acid $(2 \mathrm{x}$, $0.08 \mathrm{M}$ in $\mathrm{H}_{2} \mathrm{O}$ ), saturated $\mathrm{NaHCO}_{3}$, and brine, then dried over $\mathrm{MgSO}_{4}$, gravity filtered, and concentrated under reduced pressure.

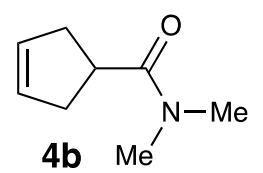

$\mathrm{N}, \mathrm{N}$-dimethylcyclopent-3-ene-1-carboxamide (4b): The title compound was synthesized via General Procedure A with cyclopent-3-ene-1-carboxylic acid and dimethylamine hydrochloride solution (2 M in THF). Purification via silica gel column chromatography (2:1 hexanes:diethyl ether) and Kugelröhr short path distillation yielded product as a colorless oil $(0.95 \mathrm{~g}, 57 \%)$.

IR (neat): 3054 (w), 2925 (m), 2849 (m), 1632 (s), 1396 (m), 1140 (m), $728(\mathrm{~m}) \mathrm{cm}^{-1} ;{ }^{\mathbf{1}} \mathbf{H}$ NMR (400 MHz, CDCl 3 ): $\delta 5.62(\mathrm{~s}, 2 \mathrm{H}), 3.30(\mathrm{tt}, J=9.4,6.8 \mathrm{~Hz}, 1 \mathrm{H}), 3.03(\mathrm{~s}, 3 \mathrm{H}), 2.94(\mathrm{~s}, 3 \mathrm{H}), 2.72$ - 2.49 (m, 4H); ${ }^{13} \mathbf{C}$ NMR (101 MHz, $\left.\mathbf{C D C l} 3\right): \delta 175.5,128.8,39.3,37.2,36.6,35.7$; HRMS (ESI) $\mathrm{m} / \mathrm{z}:[\mathrm{M}+\mathrm{Na}]^{+}$Calcd for $\mathrm{C}_{8} \mathrm{H}_{13} \mathrm{NONa}$ 162.0889; Found 162.0889 .

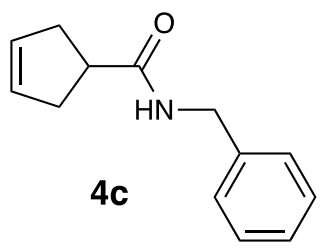

$N$-benzylcyclopent-3-ene-1-carboxamide (4c): The title compound was synthesized via General Procedure A with cyclopent-3-ene-1-carboxylic acid and benzylamine. Purification via silica gel column chromatography ( $4: 1$ hexanes:ethyl acetate) yielded product as a white solid $(0.69 \mathrm{~g}, 68 \%)$. Spectral data was in accordance with that of the literature. ${ }^{4}$

IR (neat): 3271 (s), 3053 (m), 2898 (m), 1636 (s), 1544 (s), 693 (s) cm ${ }^{-1} ;{ }^{1} \mathbf{H}$ NMR (600 MHz, $\left.\mathbf{C D C l}_{3}\right): \delta 7.56-6.90(\mathrm{~m}, 5 \mathrm{H}), 5.74(\mathrm{br} \mathrm{s}, 1 \mathrm{H}), 5.69(\mathrm{~s}, 2 \mathrm{H}), 4.46(\mathrm{~d}, J=5.7 \mathrm{~Hz}, 2 \mathrm{H}), 2.98(\mathrm{td}, J$ $=8.9,4.6 \mathrm{~Hz}, 1 \mathrm{H}), 2.75-2.46(\mathrm{~m}, 4 \mathrm{H}) ;{ }^{13} \mathbf{C}$ NMR (126 MHz, $\left.\mathbf{C D C l}_{3}\right): \delta 175.8,138.6,129.3$, $128.7,127.8,127.5,43.6,43.5,37.0$.

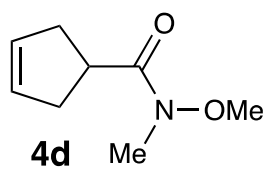

$N$-methoxy- $N$-methylcyclopent-3-ene-1-carboxamide (4d): The title compound was synthesized via General Procedure A with cyclopent-3-ene-1-carboxylic acid and $\mathrm{N}, \mathrm{O}$ dimethylhydroxylamine hydrochloride. Purification via silica gel column chromatography (1:1 hexanes:diethyl ether) yielded product as a colorless oil $(1.3 \mathrm{~g}, 71 \%)$. Spectral data was in accordance with that of the literature. ${ }^{6}$

${ }^{1}$ H NMR (600 MHz, CDCl $): \delta 5.65$ (s, 2H), 3.70 (s, 3H), 3.48 (s, 1H), 3.20 (s, 3H), $2.70-2.55$ $(\mathrm{m}, 4 \mathrm{H})$. 


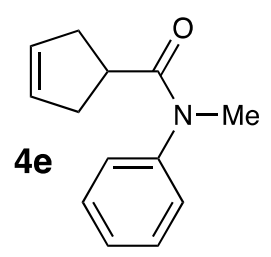

$N$-methyl- $N$-phenylcyclopent-3-ene-1-carboxamide (4e): The title compound was synthesized via General Procedure A with cyclopent-3-ene-1-carboxylic acid and $N$-methylaniline. Purification via silica gel column chromatography (3:1 hexanes:diethyl ether) and Kugelröhr short path distillation yielded product as a colorless oil (4.3 g, 71\%).

IR (neat): 3054 (w), 2916 (w), 1737 (m), 1650 (s), 1593 (s), 729 (s) cm ${ }^{-1}$; ${ }^{\mathbf{H}} \mathbf{H}$ NMR (600 MHz, CDCl3): $\delta 7.40(\mathrm{td}, J=7.8,1.9 \mathrm{~Hz}, 2 \mathrm{H}), 7.34-7.29(\mathrm{~m}, 1 \mathrm{H}), 7.20-7.15(\mathrm{~m}, 2 \mathrm{H}), 5.55-5.52(\mathrm{~m}$, $2 \mathrm{H}), 3.26(\mathrm{~d}, J=2.2 \mathrm{~Hz}, 3 \mathrm{H}), 3.01-2.93(\mathrm{~m}, 1 \mathrm{H}), 2.65(\mathrm{dd}, J=14.9,7.3 \mathrm{~Hz}, 2 \mathrm{H}), 2.28(\mathrm{dd}, J=$

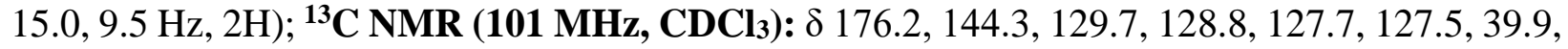
37.7, 27.1; LRMS (ESI) m/z: [M+H] $]^{+}$Calcd for $\mathrm{C}_{13} \mathrm{H}_{16} \mathrm{NO} 202.1$; Found 202.2.

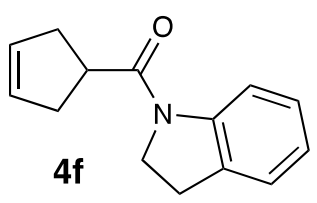

cyclopent-3-en-1-yl(indolin-1-yl)methanone (4f): The title compound was synthesized via General Procedure A with cyclopent-3-ene-1-carboxylic acid and indoline. Purification via silica gel column chromatography (10:1 hexanes:diethyl ether) and recrystallization in hexanes:EtOAc yielded product as a purple solid $(0.48 \mathrm{~g}, 45 \%)$.

IR (neat): 2938 (w), 2846 (w), 1646 (s), 1597 (m), 1459 (s), 765 (s) cm ${ }^{-1} ;{ }^{1}$ H NMR (600 MHz, CDCl$\left._{3}\right): \delta 8.27(\mathrm{~d}, J=8.1 \mathrm{~Hz}, 1 \mathrm{H}), 7.19(\mathrm{t}, J=8.3 \mathrm{~Hz}, 2 \mathrm{H}), 7.01(\mathrm{t}, J=7.4 \mathrm{~Hz}, 1 \mathrm{H}), 5.71(\mathrm{~s}, 2 \mathrm{H})$, $4.15(\mathrm{t}, J=8.5 \mathrm{~Hz}, 2 \mathrm{H}), 3.35(\mathrm{td}, J=9.3,4.7 \mathrm{~Hz}, 1 \mathrm{H}), 3.21(\mathrm{t}, J=8.6 \mathrm{~Hz}, 2 \mathrm{H}), 2.81(\mathrm{dt}, J=10.9$, $5.3 \mathrm{~Hz}, 2 \mathrm{H}), 2.69$ (dd, $J=15.0,9.3 \mathrm{~Hz}, 2 \mathrm{H}) ;{ }^{13} \mathbf{C ~ N M R}\left(\mathbf{1 2 6} \mathbf{M H z}, \mathbf{C D C l}_{3}\right): \delta 174.1,143.4,131.2$, 128.8, 127.6, 124.5, 123.5, 117.3, 48.1, 41.9, 36.5, 30.9, 28.1; LRMS (ESI) m/z: $[\mathrm{M}+\mathrm{H}]^{+} \mathrm{Calcd}$ for $\mathrm{C}_{14} \mathrm{H}_{16} \mathrm{NO} 214.1$; Found 214.2.

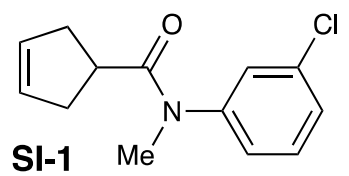

$N$-(3-chlorophenyl)- $N$-methylcyclopent-3-ene-1-carboxamide (SI-1): The title compound was synthesized via General Procedure A with cyclopent-3-ene-1-carboxylic acid and 3-chloro- $N$ methylaniline. Purification via silica gel column chromatography (75:23:2 hexanes:diethyl ether:triethylamine) and Kugelröhr short path distillation yielded product as a colorless oil (1.9 g, $68 \%)$.

IR (neat): 3057 (w), 2919 (w), 2850 (w), 1651 (s), 1589 (s), 726 (s) cm ${ }^{-1} ;{ }^{\mathbf{1}} \mathbf{H}$ NMR (500 MHz, $\left.\mathbf{C D C l}_{3}\right): \delta 7.41-7.32(\mathrm{~m}, 2 \mathrm{H}), 7.24(\mathrm{t}, J=2.0 \mathrm{~Hz}, 1 \mathrm{H}), 7.12(\mathrm{dt}, J=7.4,1.8 \mathrm{~Hz}, 1 \mathrm{H}), 5.59(\mathrm{~s}$, 2H), 3.29 (s, 3H), 2.99 (s, 1H), 2.69 (dd, $J=14.2,7.2 \mathrm{~Hz}, 2 \mathrm{H}), 2.39-2.31(\mathrm{~m}, 2 \mathrm{H}) ;{ }^{13} \mathbf{C}$ NMR (126 MHz, CDCl $): ~ \delta 176.0,145.5,135.1,130.7,128.8,128.1,127.9,125.9,77.2,40.1,37.7$; LRMS (ESI) m/z: [M+H] ${ }^{+}$Calcd for $\mathrm{C}_{13} \mathrm{H}_{15} \mathrm{ClNO} 236.1$; Found 236.0. 


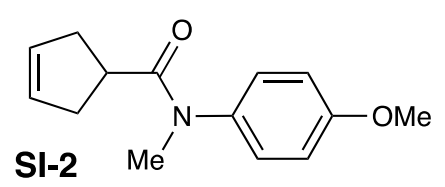

$N$-(4-methoxyphenyl)- $N$-methylcyclopent-3-ene-1-carboxamide (SI-2): The title compound was synthesized via General Procedure A with cyclopent-3-ene-1-carboxylic acid and 4-methoxy$N$-methylaniline. Purification via silica gel column chromatography (75:23:2 hexanes:diethyl ether:triethylamine) and recrystallization $\left(\mathrm{CH}_{2} \mathrm{Cl}_{2}\right.$ /pentane) yielded product as a colorless oil (2.2 $\mathrm{g}, 79 \%)$.

IR (neat): 3052 (w), 2914 (w), 2840 (w), 1645 (s), 1508 (s), 1244 (s), 727 (s) cm ${ }^{-1} ;{ }^{\mathbf{1}} \mathbf{H}$ NMR (500 MHz, CDCl $): \delta 7.16-7.09(\mathrm{~m}, 2 \mathrm{H}), 6.97-6.90(\mathrm{~m}, 2 \mathrm{H}), 5.57(\mathrm{~s}, 2 \mathrm{H}), 3.85(\mathrm{~s}, 3 \mathrm{H}), 3.26(\mathrm{~s}, 3 \mathrm{H})$, $3.01(\mathrm{tt}, J=9.5,7.4 \mathrm{~Hz}, 1 \mathrm{H}), 2.72-2.62(\mathrm{~m}, 2 \mathrm{H}), 2.36-2.26(\mathrm{~m}, 2 \mathrm{H}) ;{ }^{13} \mathbf{C}$ NMR (126 MHz, CDCl$\left._{3}\right): \delta 176.5,158.9,137.1,128.9,128.6,114.8,55.5,40.0,37.8,37.6 ;$ LRMS (ESI) m/z: $[\mathrm{M}+\mathrm{H}]^{+}$Calcd for $\mathrm{C}_{14} \mathrm{H}_{18} \mathrm{NO}_{2} 232.1$; Found 232.2.

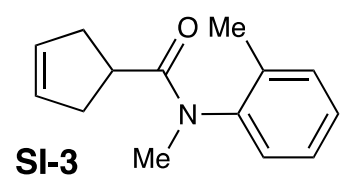

$\boldsymbol{N}$-methyl- $\boldsymbol{N}$-(o-tolyl)cyclopent-3-ene-1-carboxamide (SI-3): The title compound was synthesized via General Procedure A with cyclopent-3-ene-1-carboxylic acid and N,2dimethylaniline. Purification via silica gel column chromatography (3:1 hexanes:diethyl ether) and Kugelröhr short path distillation yielded product as a white solid (0.66 g, 61\%).

IR (neat): 3054 (w), 2918 (w), 2849 (w), 1737 (w), 1646 (s), $1384(\mathrm{~m}), 1101$ (m), 725 (s) cm ; $^{-1}$ ${ }^{1}$ H NMR (500 MHz, CDCl 3$): \delta 7.34-7.22(\mathrm{~m}, 3 \mathrm{H}), 7.13(\mathrm{dd}, J=7.1,1.9 \mathrm{~Hz}, 1 \mathrm{H}), 5.62-5.51$ $(\mathrm{m}, 2 \mathrm{H}), 3.22(\mathrm{~s}, 3 \mathrm{H}), 2.84(\mathrm{tt}, J=9.2,7.6 \mathrm{~Hz}, 1 \mathrm{H}), 2.75(\mathrm{ddp}, J=15.7,7.9,2.8 \mathrm{~Hz}, 1 \mathrm{H}), 2.60$ $(\mathrm{ddp}, J=15.6,7.8,2.7 \mathrm{~Hz}, 1 \mathrm{H}), 2.36-2.26(\mathrm{~m}, 2 \mathrm{H}), 2.25(\mathrm{~s}, 3 \mathrm{H}) ;{ }^{13} \mathbf{C}$ NMR (126 MHz, CDCl3, mix of rotomers ): $\delta 176.5,142.8,135.6,131.4,129.2,128.5,128.3,128.3,127.3,40.1,38.0,37.0$, 36.2, 17.4; LRMS (ESI) m/z: [M+H] ${ }^{+}$Calcd for $\mathrm{C}_{14} \mathrm{H}_{18} \mathrm{NO} 216.1$; Found 216.2.

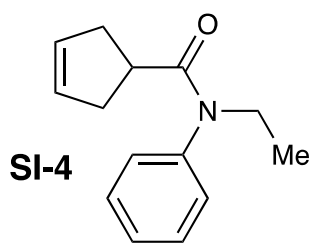

$N$-ethyl- $N$-phenylcyclopent-3-ene-1-carboxamide (SI-4): The title compound was synthesized via General Procedure A with cyclopent-3-ene-1-carboxylic acid and $N$-ethylaniline. Purification via silica gel column chromatography (75:23:2 hexanes:diethyl ether:triethylamine) and Kugelröhr short path distillation yielded product as a colorless oil $(2.2 \mathrm{~g}, 83 \%)$.

IR (neat): 3055 (w), 2970 (w), 2931 (w), 1649 (s), 1594 (m), 1246 (s), 698 (s) cm ${ }^{-1}$; ${ }^{\mathbf{1}} \mathbf{H}$ NMR (400 MHz, CDCl3): $\delta 7.40(\mathrm{dd}, J=8.3,6.7 \mathrm{~Hz}, 2 \mathrm{H}), 7.36-7.28(\mathrm{~m}, 1 \mathrm{H}), 7.18-7.11(\mathrm{~m}, 2 \mathrm{H})$, $5.52(\mathrm{~s}, 2 \mathrm{H}), 3.74(\mathrm{q}, J=7.1 \mathrm{~Hz}, 2 \mathrm{H}), 2.88(\mathrm{tt}, J=9.5,7.4 \mathrm{~Hz}, 1 \mathrm{H}), 2.63(\mathrm{dd}, J=14.4,7.3 \mathrm{~Hz}$, 2H), $2.26(\mathrm{dt}, J=14.1,6.6 \mathrm{~Hz}, 2 \mathrm{H}), 1.09(\mathrm{t}, J=7.2 \mathrm{~Hz}, 3 \mathrm{H}) ;{ }^{13} \mathbf{C}$ NMR (101 MHz, CDCl $): \delta$ 175.5, 142.5, 129.5, 128.8, 128.7, 127.8, 44.2, 40.3, 37.6, 13.0; LRMS (ESI) m/z: $[\mathrm{M}+\mathrm{H}]^{+} \mathrm{Calcd}$ for $\mathrm{C}_{14} \mathrm{H}_{18} \mathrm{NO} 216.1$; Found 216.2. 


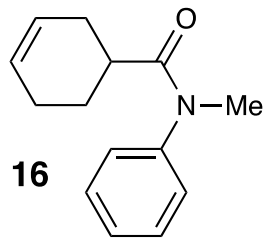

$N$-methyl- $N$-phenylcyclohex-3-ene-1-carboxamide (16): The title compound was synthesized via General Procedure A with cyclohex-3-ene-1-carboxylic acid and $N$-methylaniline. Purification via silica gel column chromatography (3:1 hexanes:diethyl ether) and Kugelröhr short path distillation yielded product as a colorless oil $(1.3 \mathrm{~g}, 60 \%)$.

IR (neat): 3023 (w), 2910 (w), 2838 (w), 1645 (s), 1594 (m), 1494 (m), 1386 (m), 1118 (m), 719 (s) $\mathrm{cm}^{-1} ;{ }^{1} \mathbf{H}$ NMR (400 MHz, CDCl3): $\delta 7.39(\mathrm{dd}, J=8.3,6.7 \mathrm{~Hz}, 2 \mathrm{H}), 7.31(\mathrm{t}, J=7.3 \mathrm{~Hz}, 1 \mathrm{H})$, $7.20-7.12(\mathrm{~m}, 2 \mathrm{H}), 5.54(\mathrm{~h}, J=9.6 \mathrm{~Hz}, 2 \mathrm{H}), 3.24(\mathrm{~s}, 3 \mathrm{H}), 2.42(\mathrm{dq}, J=12.1,5.8 \mathrm{~Hz}, 1 \mathrm{H}), 2.31$ $(\mathrm{ddq}, J=15.1,11.1,2.2 \mathrm{~Hz}, 1 \mathrm{H}), 2.01-1.87(\mathrm{~m}, 2 \mathrm{H}), 1.72(\mathrm{~d}, J=6.1 \mathrm{~Hz}, 3 \mathrm{H}) ;{ }^{13} \mathbf{C}$ NMR $(\mathbf{1 0 1}$ MHz, CDCl3): $\delta$ 176.2, 144.1, 129.8, 127.7, 127.2, 126.1, 125.7, 37.5, 37.2, 28.2, 25.8, 24.6; LRMS (ESI) m/z: [M+H] ${ }^{+}$Calcd for $\mathrm{C}_{14} \mathrm{H}_{18} \mathrm{NO} 216.1$; Found 216.2.

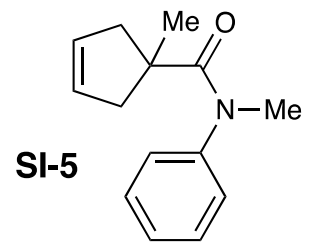

$\boldsymbol{N}$,1-dimethyl- $\boldsymbol{N}$-phenylcyclopent-3-ene-1-carboxamide (SI-5): The title compound was synthesized via General Procedure A with 1-methylcyclopent-3-ene-1-carboxylic acid ${ }^{4}$ and $N$ methylaniline. Purification via silica gel column chromatography (4:1 hexanes:diethyl ether) and recrystallization (hexanes) yielded product as a white solid $(1.7 \mathrm{~g}, 57 \%)$.

IR (neat): 3052 (w), 2930 (w), 1635 (s), 1592 (s), 1493 (m), 1354 (m), 701 (s), 574 (s) cm ${ }^{-1} ;{ }^{1} \mathbf{H}$ NMR (500 MHz, CDCl $): \delta 7.45-7.38(\mathrm{~m}, 2 \mathrm{H}), 7.38-7.31(\mathrm{~m}, 1 \mathrm{H}), 7.30-7.23(\mathrm{~m}, 2 \mathrm{H}), 5.50$ $(\mathrm{s}, 2 \mathrm{H}), 3.27(\mathrm{~s}, 3 \mathrm{H}), 2.82(\mathrm{~d}, J=15.1 \mathrm{~Hz}, 2 \mathrm{H}), 1.83(\mathrm{~d}, J=15.9 \mathrm{~Hz}, 2 \mathrm{H}), 1.21(\mathrm{~s}, 3 \mathrm{H}) ;{ }^{13} \mathbf{C}$ NMR (101 MHz, CDCl3): $\delta$ 177.6, 144.6, 129.1, 128.7, 128.0, 127.6, 50.3, 45.2, 40.4, 27.9; LRMS (ESI) m/z: $[\mathrm{M}+\mathrm{H}]^{+}$Calcd for $\mathrm{C}_{14} \mathrm{H}_{18} \mathrm{NO} 216.1$; Found 216.2.

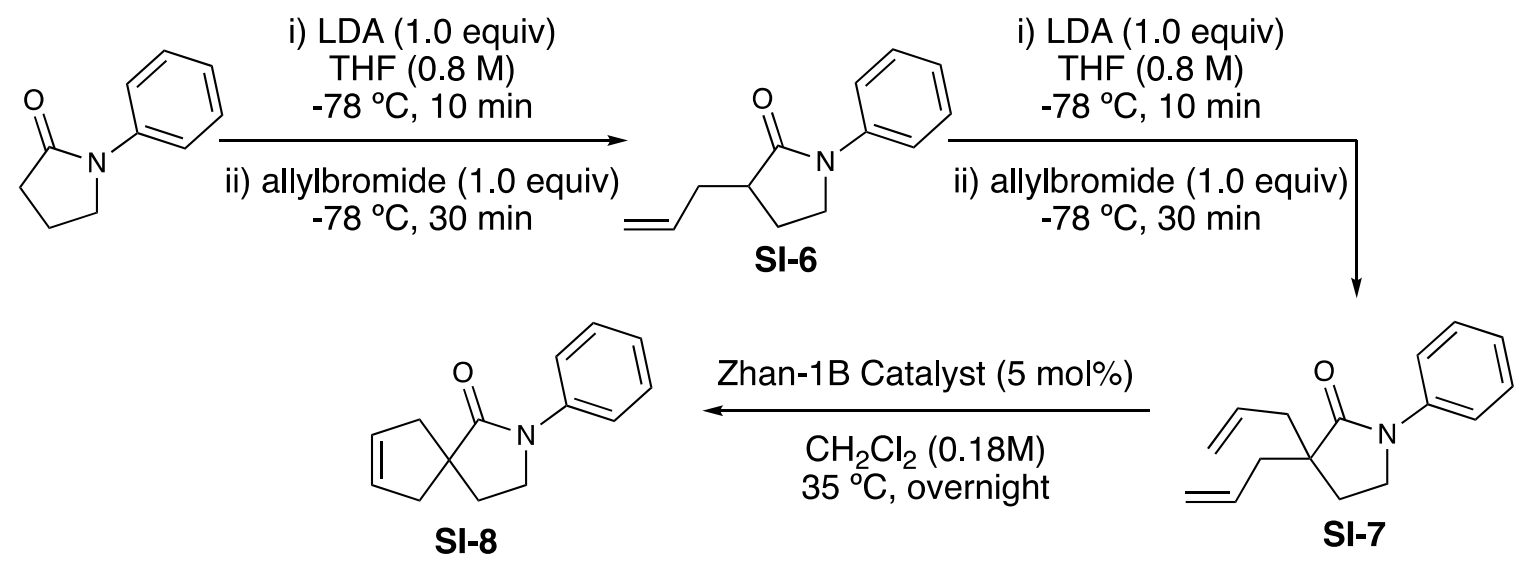

3-allyl-1-phenylpyrrolidin-2-one (SI-6): To a flame-dried round-bottom flask equipped with a stir bar was added diisopropylamine (2.8 mL, $20 \mathrm{mmol}, 1.0$ equiv.) and THF $(10 \mathrm{~mL})$ and the contents were cooled to $-78^{\circ} \mathrm{C}$ in a dry ice/acetone bath. $n$-Butyllithium solution $(1.9 \mathrm{M}$ in hexanes, $10.6 \mathrm{~mL}, 20 \mathrm{mmol}, 1.0$ equiv.) was added slowly and the reaction contents were stirred for $15 \mathrm{~min}$ 
at $-78^{\circ} \mathrm{C}$. A second flame-dried round-bottom flask equipped with a stir bar was charged with 1phenylpyrrolidin-2-one $\left(3.2 \mathrm{~g}, 20 \mathrm{mmol}, 1.0\right.$ equiv.) then evacuated/backfilled with $\mathrm{N}_{2}(3 \mathrm{x})$. THF $(15 \mathrm{~mL})$ was added, and this solution was transferred via syringe to the lithium diisopropylamide solution slowly. After stirring for $10 \mathrm{~min}$ at $-78^{\circ} \mathrm{C}$, allylbromide (1.7 mL, $20 \mathrm{mmol}, 1.0$ equiv.) was added and reaction stirs for an additional $30 \mathrm{~min}$ at $-78{ }^{\circ} \mathrm{C}$. The reaction was quenched with sat. ammonium chloride $(20 \mathrm{~mL})$ and product was extracted with $\mathrm{CH}_{2} \mathrm{Cl}_{2}(3 \times 20 \mathrm{~mL})$. Combined organics were dried over $\mathrm{MgSO}_{4}$, gravity filtered, and concentrated under reduced pressure. Purification via silica gel column chromatography (10:1 hexanes:diethyl ether) and recrystallization $\left(\mathrm{CH}_{2} \mathrm{Cl}_{2}\right.$ /pentane) yielded product as a white solid (2.6 g, 64\%). Spectral data was in accordance with that of the literature. ${ }^{7}$

IR (neat): 3057 (w), 2967 (w), 1686 (s), 1596 (m), 1401 (s), 1318 (s), 906 (s), 760 (s) cm ${ }^{-1} ;{ }^{1} \mathbf{H}$ NMR (400 MHz, CDCl3): $\delta 7.65-7.58$ (m, 2H), $7.39-7.30(\mathrm{~m}, 2 \mathrm{H}), 7.16-7.08$ (m, 1H), 5.82 $(\mathrm{ddt}, J=17.1,10.2,7.0 \mathrm{~Hz}, 1 \mathrm{H}), 5.12(\mathrm{dq}, J=17.0,1.5 \mathrm{~Hz}, 1 \mathrm{H}), 5.11-5.03(\mathrm{~m}, 1 \mathrm{H}), 3.83-3.70$ $(\mathrm{m}, 2 \mathrm{H}), 2.76-2.61(\mathrm{~m}, 2 \mathrm{H}), 2.34-2.21(\mathrm{~m}, 2 \mathrm{H}), 1.85(\mathrm{dq}, J=12.8,8.6 \mathrm{~Hz}, 1 \mathrm{H}) ;{ }^{13} \mathbf{C}$ NMR (101 MHz, CDCl3): $\delta 175.2,139.5,135.4,128.8,124.4,119.7,117.1,46.7,42.9,35.4,23.9$.

3,3-diallyl-1-phenylpyrrolidin-2-one (SI-7): To a flame-dried round-bottom flask equipped with a stir bar was added diisopropylamine $(0.85 \mathrm{~mL}, 6.1 \mathrm{mmol}, 1.0$ equiv. $)$ and THF $(5 \mathrm{~mL})$ and the contents were cooled to $-78^{\circ} \mathrm{C}$ in a dry ice/acetone bath. $n$-Butyllithium solution (1.9 M in hexanes, $3.2 \mathrm{~mL}, 6.1 \mathrm{mmol}, 1.0$ equiv.) was added slowly and the reaction contents are stirred for $15 \mathrm{~min}$ at $-78{ }^{\circ} \mathrm{C}$. A second flame-dried round-bottom flask equipped with a stir bar was charged with 3allyl-1-phenylpyrrolidin-2-one (1.2 g, $6.1 \mathrm{mmol}, 1.0$ equiv.) then evacuated/backfilled with $\mathrm{N}_{2}$ $(3 \mathrm{x})$. THF $(10 \mathrm{~mL})$ was added, and this solution was transferred via syringe to the lithium diisopropylamide solution slowly. After stirring for $10 \mathrm{~min}$ at $-78{ }^{\circ} \mathrm{C}$, allylbromide $(0.53 \mathrm{~mL}, 6.1$ mmol, 1.0 equiv.) was added and reaction was stirred for an additional $30 \mathrm{~min}$ at $-78{ }^{\circ} \mathrm{C}$. The reaction was quenched with sat. ammonium chloride $(10 \mathrm{~mL})$ solution and product was extracted with $\mathrm{CH}_{2} \mathrm{Cl}_{2}$ (3x $\left.10 \mathrm{~mL}\right)$. Combined organics were dried over $\mathrm{MgSO}_{4}$, gravity filtered, and concentrated under reduced pressure. Purification via silica gel column chromatography (20:1 hexanes:diethyl ether) yielded product as a colorless oil $(0.53 \mathrm{~g}, 22 \%)$. Spectral data was in accordance with that of the literature. ${ }^{7}$

IR (neat): 3051 (w), 2897 (w), 1686 (s), 1638 (m), 1488 (s), 1392 (s), 1223 (m), 914 (s), 757 (s), 689 (s) cm ${ }^{-1}$; ${ }^{1} \mathbf{H}$ NMR (500 MHz, CDCl 3$): \delta 7.70-7.64(\mathrm{~m}, 2 \mathrm{H}), 7.43-7.35(\mathrm{~m}, 2 \mathrm{H}), 7.17$ (td, $J=7.4,1.2 \mathrm{~Hz}, 1 \mathrm{H}), 5.82(\mathrm{dddd}, J=16.9,10.1,8.3,6.5 \mathrm{~Hz}, 2 \mathrm{H}), 5.21-5.10(\mathrm{~m}, 4 \mathrm{H}), 3.77-3.70$ $(\mathrm{m}, 2 \mathrm{H}), 2.48(\mathrm{ddt}, J=13.6,6.4,1.4 \mathrm{~Hz}, 2 \mathrm{H}), 2.30(\mathrm{dd}, J=13.7,8.3 \mathrm{~Hz}, 2 \mathrm{H}), 2.12-2.06(\mathrm{~m}, 2 \mathrm{H})$; ${ }^{13}$ C NMR (126 MHz, CDCl3): $\delta$ 176.8, 139.5, 133.7, 128.8, 124.5, 120.0, 118.8, 49.0, 45.7, 41.7, 26.4 .

2-phenyl-2-azaspiro[4.4]non-7-en-1-one (SI-8): Procedure adapted from literature procedure. ${ }^{8}$ To a flame-dried round-bottom flask equipped with a stir bar was added Zhan-1B catalyst (29 mg, 0.040 mmol, 0.050 equiv.) in a $\mathrm{N}_{2}$ filled glovebox. The flask was capped with a septum and removed from the glovebox. $\mathrm{CH}_{2} \mathrm{Cl}_{2}(5 \mathrm{~mL})$ was added to make a catalyst solution. A second flame-dried round-bottom flask equipped with a stir bar was charged with 3,3-diallyl-1phenylpyrrolidin-2-one (1.9 g, $7.9 \mathrm{mmol}, 1.0$ equiv.) then evacuated/backfilled with $\mathrm{N}_{2}(3 \mathrm{x})$. $\mathrm{CH}_{2} \mathrm{Cl}_{2}$ (40 mL) was added, followed by transferring the catalyst solution via syringe. The reaction was heated in an oil bath to $35^{\circ} \mathrm{C}$ and stirred overnight. Solvent was concentrated under reduced 
pressure. Purification via silica gel column chromatography (3:1 hexanes:diethyl ether) and recrystallization (hexanes/diethyl ether) yielded product as a white crystal (791 $\mathrm{mg}, 47 \%)$.

IR (neat): 3094 (w), 2966 (w), 2871 (w), 1674 (s), 1596 (m), 1486 (s), 1391 (s), 1224 (s), 756 (s), 688 (s), 672 (s) cm ${ }^{-1} ;{ }^{1} \mathbf{H}$ NMR (400 MHz, CDCl $): \delta 7.70-7.63(\mathrm{~m}, 2 \mathrm{H}), 7.40-7.31$ (m, 2H), $7.12(\mathrm{tt}, J=7.2,1.2 \mathrm{~Hz}, 1 \mathrm{H}), 5.66(\mathrm{~s}, 2 \mathrm{H}), 3.77(\mathrm{t}, J=6.7 \mathrm{~Hz}, 2 \mathrm{H}), 2.92(\mathrm{dd}, J=4.3,1.6 \mathrm{~Hz}, 1 \mathrm{H})$, $2.87(\mathrm{~s}, 1 \mathrm{H}), 2.41-2.36(\mathrm{~m}, 1 \mathrm{H}), 2.34(\mathrm{~s}, 1 \mathrm{H}), 2.12(\mathrm{t}, J=6.7 \mathrm{~Hz}, 2 \mathrm{H}) ;{ }^{13} \mathrm{C}$ NMR (101 MHz, CDCl$\left._{3}\right): \delta 178.4,139.8,128.8,128.3,124.2,119.5,51.4,45.5,43.6,35.0 ;$ LRMS (ESI) m/z: $[\mathrm{M}+\mathrm{H}]^{+}$Calcd for $\mathrm{C}_{14} \mathrm{H}_{16} \mathrm{NO} 214.1$; Found 214.2.

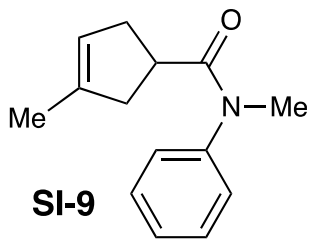

$\boldsymbol{N}, 3$-dimethyl- $\boldsymbol{N}$-phenylcyclopent-3-ene-1-carboxamide (SI-9): The title compound was synthesized via General Procedure A with 3-methylcyclopent-3-ene-1-carboxylic acid ${ }^{4}$ and $N$ methylaniline. Purification via silica gel column chromatography (4:1 hexanes:diethyl ether) and Kugelröhr short path distillation yielded product as a colorless oil (1.2 g, 69\%).

IR (neat): 3040 (w), 2912 (w), 1737 (s), 1594 (m), 1494 (m), 1422 (m), 1120 (m), 773 (s), 727 (s) $\mathrm{cm}^{-1} ;{ }^{1} \mathbf{H}$ NMR $\left(\mathbf{5 0 0} \mathbf{M H z}, \mathbf{C D C l}_{3}\right): \delta 7.43(\mathrm{dd}, J=8.4,7.0 \mathrm{~Hz}, 2 \mathrm{H}), 7.35(\mathrm{t}, J=7.4 \mathrm{~Hz}, 1 \mathrm{H}), 7.23$ $-7.17(\mathrm{~m}, 2 \mathrm{H}), 5.14(\mathrm{~d}, J=3.4 \mathrm{~Hz}, 1 \mathrm{H}), 3.29$ (s, 3H), 3.06 (ddd, $J=16.8,9.5,7.4 \mathrm{~Hz}, 1 \mathrm{H}), 2.69$ $-2.59(\mathrm{~m}, 2 \mathrm{H}), 2.17(\mathrm{td}, J=12.3,10.8,4.7 \mathrm{~Hz}, 1 \mathrm{H}), 1.66(\mathrm{~s}, 3 \mathrm{H}) ;{ }^{13} \mathbf{C}$ NMR (126 MHz, CDCl$)$ : $\delta 176.4,144.4,138.5,129.7,127.7,127.5,122.4,41.7,40.8,37.9,37.6,16.2 ;$ LRMS (ESI) m/z: $[\mathrm{M}+\mathrm{H}]^{+}$Calcd for $\mathrm{C}_{14} \mathrm{H}_{18} \mathrm{NO} 216.1$; Found 216.2.
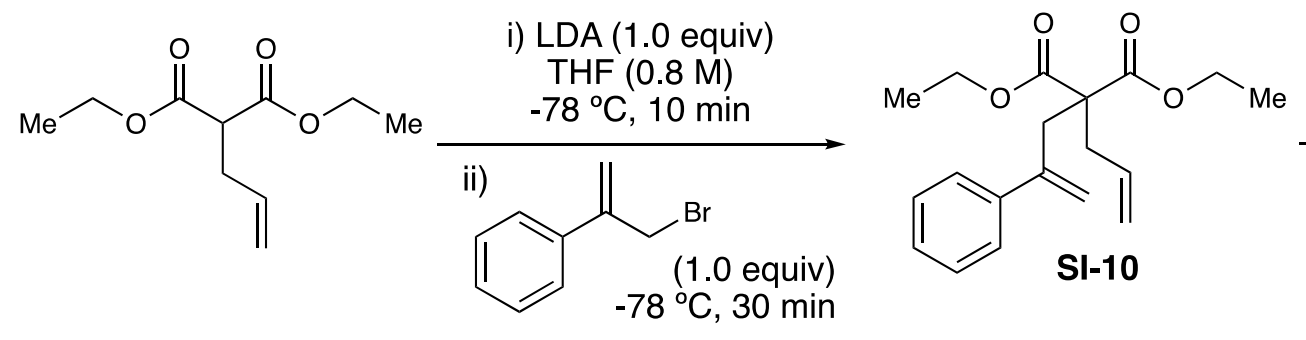

Zhan-1B Catalyst

$(5 \mathrm{~mol} \%)$

$\mathrm{CH}_{2} \mathrm{Cl}_{2}(0.18 \mathrm{M})$

$35^{\circ} \mathrm{C}$, overnight

1) $\mathrm{KOH}$ (3.2 equiv)
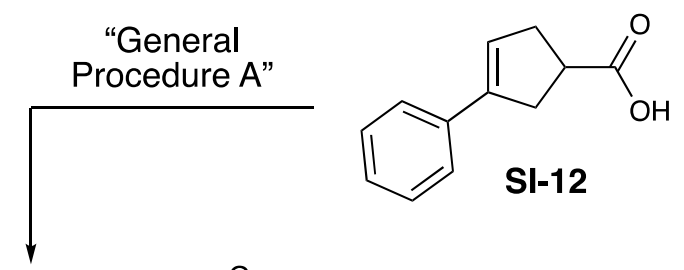

4:1 EtOH: $\mathrm{H}_{2} \mathrm{O}(0.34 \mathrm{M})$

$45^{\circ} \mathrm{C}$, overnight

2) $180^{\circ} \mathrm{C}, 1 \mathrm{~h}$

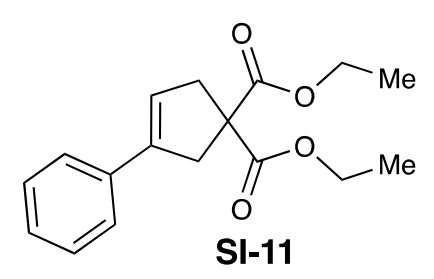<smiles>CN(C(=O)C1CC=C(c2ccccc2)C1)c1ccccc1</smiles>

diethyl 2-allyl-2-(2-phenylallyl)malonate (SI-10): To a flame-dried round-bottom flask equipped with a stir bar was added sodium hydride (60 wt\% in mineral oil, $0.40 \mathrm{~g}, 10 \mathrm{mmol}, 1.2$ equiv.) then evacuated/backfilled with $\mathrm{N}_{2}(3 \mathrm{x})$. THF $(60 \mathrm{~mL})$ was added and the solution was 
cooled to $0{ }^{\circ} \mathrm{C}$ in an ice bath. Diethyl allylmalonate $(1.6 \mathrm{~mL}, 8.5 \mathrm{mmol}, 1.0$ equiv.) was added dropwise and after gas evolution ceased, a-(bromomethyl)styrene ${ }^{9}$ (2.0 g, 10 mmol, 1.2 equiv.) was added dropwise. Reaction was allowed to slowly warm to rt over $1 \mathrm{~h}$ then was heated in an oil bath to $60{ }^{\circ} \mathrm{C}$ overnight. After cooling to $\mathrm{rt}$, the reaction is quenched with sat. ammonium chloride $(60 \mathrm{~mL})$. Product was extracted with diethyl ether $(3 \mathrm{x} 50 \mathrm{~mL})$ and combined organics were washed with brine, dried over $\mathrm{MgSO}_{4}$, gravity filtered, and concentrated under reduced pressure. Purification via silica gel column chromatography (20:1 hexanes:diethyl ether) yielded product as a colorless oil $(2.3 \mathrm{~g}, 84 \%)$. Spectral data was in accordance with that of the literature. ${ }^{10}$

${ }^{1}$ H NMR (600 MHz, CDCl3): $\delta 7.32-7.25$ (m, 4H), $7.25-7.19$ (m, 1H), 5.60 (ddt, $J=17.4$, $10.2,7.3 \mathrm{~Hz}, 1 \mathrm{H}), 5.25(\mathrm{~d}, J=1.7 \mathrm{~Hz}, 1 \mathrm{H}), 5.14(\mathrm{~d}, J=1.6 \mathrm{~Hz}, 1 \mathrm{H}), 5.05(\mathrm{ddt}, J=10.3,2.1,1.1$ $\mathrm{Hz}, 1 \mathrm{H}), 4.98(\mathrm{dq}, J=17.0,1.6 \mathrm{~Hz}, 1 \mathrm{H}), 3.93(\mathrm{dq}, J=10.7,7.1 \mathrm{~Hz}, 2 \mathrm{H}), 3.79(\mathrm{dq}, J=10.7,7.1$ $\mathrm{Hz}, 2 \mathrm{H}), 3.15(\mathrm{~d}, J=0.9 \mathrm{~Hz}, 2 \mathrm{H}), 2.57(\mathrm{dt}, J=7.3,1.3 \mathrm{~Hz}, 2 \mathrm{H}), 1.13(\mathrm{t}, J=7.1 \mathrm{~Hz}, 6 \mathrm{H}),-1.95$ (s, $1 \mathrm{H})$.

diethyl 3-phenylcyclopent-3-ene-1,1-dicarboxylate (SI-11): To a flame-dried round-bottom flask equipped with a stir bar was added Zhan-1B catalyst (26 mg, $0.36 \mathrm{mmol}, 0.050$ equiv.) in a $\mathrm{N}_{2}$ filled glovebox. The flask was capped with a septum and removed from the glovebox. $\mathrm{CH}_{2} \mathrm{Cl}_{2}$ $(5 \mathrm{~mL})$ was added to make a catalyst solution. A second flame-dried round-bottom flask equipped with a stir bar was charged with diethyl 2-allyl-2-(2-phenylallyl)malonate $(2.3 \mathrm{~g}, 7.2 \mathrm{mmol}, 1.0$ equiv.) then evacuated/backfilled with $\mathrm{N}_{2}(3 \mathrm{x}) \cdot \mathrm{CH}_{2} \mathrm{Cl}_{2}(30 \mathrm{~mL})$ was added, followed by transferring the catalyst solution via syringe. The reaction was heated to $35^{\circ} \mathrm{C}$ in an oil bath and stirred overnight. Solvent was concentrated under reduced pressure. Purification via silica gel column chromatography (3:1 hexanes:diethyl ether) yielded product as a colorless oil (2.0 g, 95\%). Spectral data was in accordance with that of the literature. ${ }^{10}$

${ }^{1}$ H NMR (600 MHz, CDCl3): $\delta 7.43-7.38(\mathrm{~m}, 2 \mathrm{H}), 7.31(\mathrm{dd}, J=8.4,7.0 \mathrm{~Hz}, 2 \mathrm{H}), 7.26-7.20$ $(\mathrm{m}, 1 \mathrm{H}), 6.01(\mathrm{p}, J=2.3 \mathrm{~Hz}, 1 \mathrm{H}), 4.21(\mathrm{q}, J=7.2 \mathrm{~Hz}, 4 \mathrm{H}), 3.41(\mathrm{q}, J=2.1 \mathrm{~Hz}, 2 \mathrm{H}), 3.20(\mathrm{q}, J=$ $2.3 \mathrm{~Hz}, 2 \mathrm{H}), 1.26(\mathrm{t}, J=7.1 \mathrm{~Hz}, 6 \mathrm{H})$.

3-phenylcyclopent-3-ene-1-carboxylic acid (SI-12): Procedure adapted from literature procedure. Error! Bookmark not defined. To a round-bottom flask equipped with a stir bar was added diethyl 3-phenylcyclopent-3-ene-1,1-dicarboxylate ( $2.0 \mathrm{~g}, 6.8 \mathrm{mmol}, 1.0$ equiv.), ethanol (16 mL), water ( $4 \mathrm{~mL})$, and potassium hydroxide ( $1.3 \mathrm{~g}, 22 \mathrm{mmol}, 3.2$ equiv.). Reaction contents were heated to $45^{\circ} \mathrm{C}$ in an oil bath and stirred overnight then concentrated under reduced pressure. Diethyl ether $(10 \mathrm{~mL})$, hexanes $(5 \mathrm{~mL})$, and water $(15 \mathrm{~mL})$ were added to the resulting oil. The mixture was acidified with conc. sulfuric acid until $\mathrm{pH}$ is 1 . The mixture was extracted with ethyl acetate $(3 \times 15 \mathrm{~mL})$ and combined organics were dried over $\mathrm{MgSO}_{4}$, gravity filtered, and concentrated under reduced pressure. The resulting solid was heated to $180^{\circ} \mathrm{C}$ for $1 \mathrm{~h}$ and then returned to rt. Purification via silica gel column chromatography (3:1 hexanes:acetone) yielded product as an orange oil $(0.73 \mathrm{~g}, 57 \%)$. Spectral data was in accordance with that of the literature. ${ }^{11}$ ${ }^{1}$ H NMR (400 MHz, CDCl3): $\delta 7.49-7.37(\mathrm{~m}, 2 \mathrm{H}), 7.30(\mathrm{dd}, J=8.5,6.8 \mathrm{~Hz}, 2 \mathrm{H}), 7.25-7.18$ $(\mathrm{m}, 1 \mathrm{H}), 6.08(\mathrm{p}, J=2.3 \mathrm{~Hz}, 1 \mathrm{H}), 3.34(\mathrm{tt}, J=9.2,7.1 \mathrm{~Hz}, 1 \mathrm{H}), 3.17-2.97(\mathrm{~m}, 2 \mathrm{H}), 2.88(\mathrm{dq}, J=$ 9.2, $2.2 \mathrm{~Hz}, 2 \mathrm{H})$.

$N$-methyl- $N, 3$-diphenylcyclopent-3-ene-1-carboxamide (SI-13): The title compound was synthesized via General Procedure A with 3-phenylcyclopent-3-ene-1-carboxylic acid and $N$ - 
methylaniline. Purification via silica gel column chromatography (4:1 hexanes:diethyl ether) and recrystallization (ethyl acetate) yielded product as a white crystal $(0.17 \mathrm{~g}, 16 \%)$.

IR (neat): 3020(m), 2970 (m), 1738 (s), 1652 (s),1594 (s), 1380 (m) cm ${ }^{-1} ;{ }^{\mathbf{1}} \mathbf{H}$ NMR (400 MHz, CDCl3): $\delta 7.42(\mathrm{t}, J=7.6 \mathrm{~Hz}, 2 \mathrm{H}), 7.37-7.30(\mathrm{~m}, 3 \mathrm{H}), 7.26(\mathrm{t}, J=6.7 \mathrm{~Hz}, 2 \mathrm{H}), 7.26-7.15(\mathrm{~m}$, $3 \mathrm{H}), 5.95$ (s, 1H), $3.30(\mathrm{~s}, 3 \mathrm{H}), 3.13(\mathrm{ddd}, J=26.2,13.9,8.3 \mathrm{~Hz}, 2 \mathrm{H}), 2.91-2.80(\mathrm{~m}, 1 \mathrm{H}), 2.64$ $(\mathrm{dd}, J=15.2,9.2 \mathrm{~Hz}, 1 \mathrm{H}), 2.45(\mathrm{dd}, J=17.2,9.1 \mathrm{~Hz}, 1 \mathrm{H}) ;{ }^{13} \mathbf{C ~ N M R}\left(\mathbf{1 0 1} \mathbf{M H z}, \mathbf{C D C l}_{3}\right): \delta 175.8$, 144.2, 140.6, 136.1, 129.8, 128.2, 127.8, 127.5, 127.0, 125.5, 123.8, 40.6, 38.2, 37.7, 27.1; LRMS (ESI) m/z: $[\mathrm{M}+\mathrm{H}]^{+}$Calcd for $\mathrm{C}_{19} \mathrm{H}_{20} \mathrm{NO} 278.2$; Found 278.2.

\section{Arylboration Reactions}

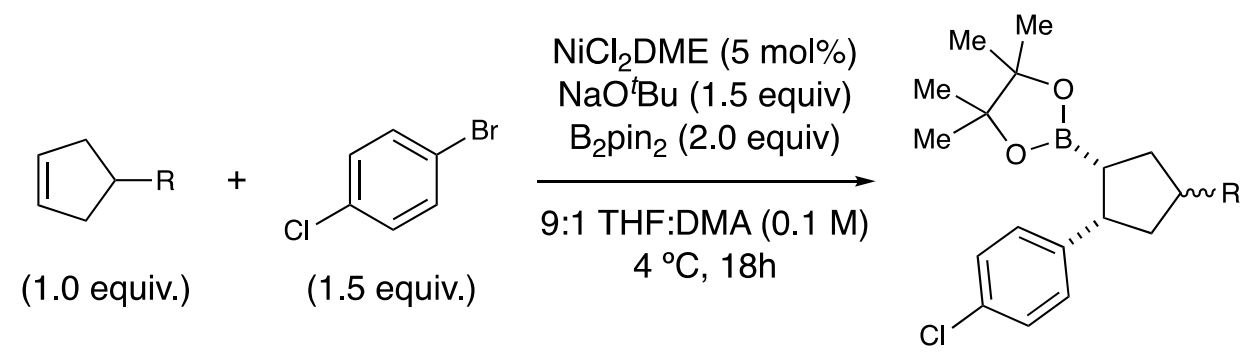

General Procedure B: Ni-Catalyzed Arylboration of Alkenes Optimization With Varied Directing Groups (Used in Scheme 2)

In an $\mathrm{N}_{2}$-filled glovebox, to an oven-dried 16 x $100 \mathrm{~mm}$ screw-capped vial was added bis(pinacolato)diboron (254 mg, $1.00 \mathrm{mmol}, 2.00$ equiv.), 1-bromo-4-chlorobenzene (144 mg, $0.750 \mathrm{mmol}, 1.50$ equiv.), and $\mathrm{NaO} t$-Bu (72 mg, $0.75 \mathrm{mmol}, 1.5$ equiv.). Note: if the alkene $(0.5$ mmol, 1.0 equiv) is a solid, it was added to the vial in the glovebox. A separate oven-dried 2-dram vial was charged with $\mathrm{Ni}(\mathrm{DME}) \mathrm{Cl}_{2}$ ( $8.2 \mathrm{mg}, 0.038 \mathrm{mmol}, 0.075$ equiv.) in an $\mathrm{N}_{2}$-filled glovebox. Both vials were sealed with a septum and removed from the glovebox. THF $(4.5 \mathrm{~mL})$ was added to the reaction vial followed by alkene $\left(0.5 \mathrm{mmol}, 1.0\right.$ equiv) and the contents were cooled to $0{ }^{\circ} \mathrm{C}$ in an ice bath. DMA $(0.75 \mathrm{~mL})$ was added to the vial containing $\mathrm{Ni}(\mathrm{DME}) \mathrm{Cl}_{2}$ to prepare the catalyst solution. The catalyst solution $\left(0.50 \mathrm{~mL}, 0.050\right.$ equiv of $\left.\mathrm{Ni}(\mathrm{DME}) \mathrm{Cl}_{2}\right)$ was transferred to the reaction vial via syringe. The septum was then quickly replaced by a Teflon-lined screw cap and the reaction was stirred at $4{ }^{\circ} \mathrm{C}$ for $18 \mathrm{~h}$ in a temperature controlled refrigerator. The reaction was quenched upon the addition of $1 \mathrm{M} \mathrm{HCl}(5 \mathrm{~mL})$, and the mixture was extracted with EtOAc (3 $3 \mathrm{~mL}$ ), dried over $\mathrm{MgSO}_{4}$, gravity filtered, and concentrated. 1,3,5-Trimethylbenzene or 1,3,5trimethoxybenzene was added as an internal standard and a small aliquot was analyzed via ${ }^{1} \mathrm{H}$ NMR.

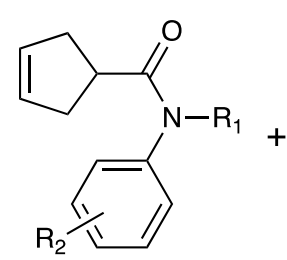

(1.0 equiv.)
$\mathrm{NiCl}_{2} \mathrm{DME}(10 \mathrm{~mol} \%)$

$\mathrm{NaO}{ }^{t} \mathrm{Bu}$ (3.0 equiv)

$\mathrm{B}_{2} \mathrm{pin}_{2}$ (4.0 equiv)

toluene $(0.1 \mathrm{M})$

$50{ }^{\circ} \mathrm{C}, 18 \mathrm{~h}$

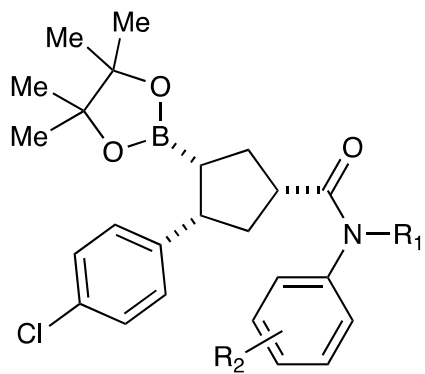

General Procedure C: Ni-Catalyzed Arylboration of Alkenes Optimization with Variation on Methylaniline Directing Group (Used in Scheme 3) 
In an $\mathrm{N}_{2}$-filled glovebox, to an oven-dried 16 x $100 \mathrm{~mm}$ screw-capped vial was added $\mathrm{Ni}(\mathrm{DME}) \mathrm{Cl}_{2}$ (11 mg, $0.050 \mathrm{mmol}, 0.10$ equiv.), bis(pinacolato)diboron (508 mg, $2.00 \mathrm{mmol}, 4.00$ equiv.), 1bromo-4-chlorobenzene (192 mg, $1.00 \mathrm{mmol}, 2.00$ equiv.), and $\mathrm{NaOt}$-Bu (144 mg, $1.50 \mathrm{mmol}$, 3.00 equiv.). Note: if the alkene $(0.5 \mathrm{mmol}, 1$ equiv.) is a solid, it was added to the vial in the glovebox. The vial was sealed with a septum and removed from the glovebox. Toluene $(5.0 \mathrm{~mL})$ was added to the reaction vial immediately followed by alkene ( $0.5 \mathrm{mmol}, 1.0$ equiv.). The septum was then quickly replaced by a Teflon-lined screw cap and the reaction was stirred at $50{ }^{\circ} \mathrm{C}$ for 18 $\mathrm{h}$ in a temperature-controlled aluminum block. The reaction was quenched upon the addition of 1 $\mathrm{M} \mathrm{HCl}(5 \mathrm{~mL})$, and the mixture was extracted with EtOAc $(3 \times 3 \mathrm{~mL})$, washed with $1 \mathrm{M} \mathrm{KOH} \mathrm{(3}$ x $5 \mathrm{~mL}$ ), dried over $\mathrm{MgSO}_{4}$, gravity filtered, and concentrated. 1,3,5-Trimethylbenzene or 1,3,5trimethoxybenzene was added as an internal standard and a small aliquot was analyzed via ${ }^{1} \mathrm{H}$ NMR.

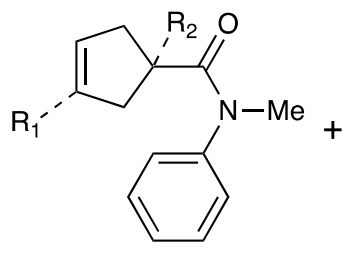

(1.0 equiv.)

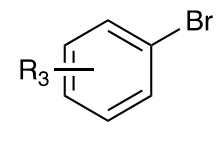

(2.0 equiv.)

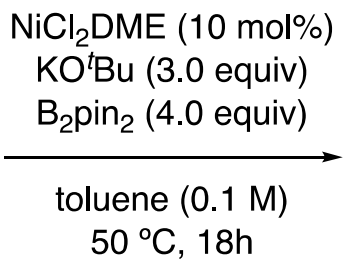

$50^{\circ} \mathrm{C}, 18 \mathrm{~h}$

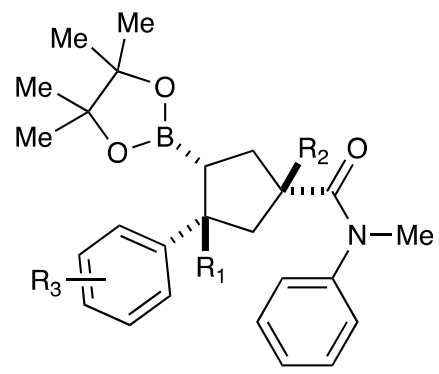

\section{General Procedure D: Ni-Catalyzed Arylboration of Alkenes}

In an $\mathrm{N}_{2}$-filled glovebox, to an oven-dried 16 x $100 \mathrm{~mm}$ screw-capped vial was added $\mathrm{Ni}(\mathrm{DME}) \mathrm{Cl}_{2}$ (11 mg, $0.050 \mathrm{mmol}, 0.10$ equiv.), bis(pinacolato)diboron (508 mg, $2.00 \mathrm{mmol}, 4.00$ equiv.), and $\mathrm{KO} t$-Bu (168 mg, $1.50 \mathrm{mmol}, 3.00$ equiv.). Note: if the alkene ( $0.5 \mathrm{mmol}, 1$ equiv.) or aryl bromide (1.0 mmol, 2.0 equiv.) is a solid, it was added to the vial in the glovebox. The vial was sealed with a septum and removed from the glovebox. Toluene $(5.0 \mathrm{~mL})$ was added to the reaction vial, followed by alkene ( $0.5 \mathrm{mmol}, 1$ equiv.) and arylbromide (1.0 mmol, 2.0 equiv.). The septum was then quickly replaced by a Teflon-lined screw cap and the reaction was stirred at $50{ }^{\circ} \mathrm{C}$ for $18 \mathrm{~h}$ in a temperature-controlled aluminum block. The reaction was quenched upon the addition of $1 \mathrm{M}$ $\mathrm{HCl}(5 \mathrm{~mL})$, and the mixture was extracted with EtOAc $(3 \times 3 \mathrm{~mL})$, washed with $1 \mathrm{M} \mathrm{KOH}(3 \times 5$ $\mathrm{mL}$ ), dried over $\mathrm{MgSO}_{4}$, gravity filtered, and concentrated. 1,3,5-Trimethylbenzene or 1,3,5trimethoxybenzene was added as an internal standard and a small aliquot was analyzed via ${ }^{1} \mathrm{H}$ NMR.

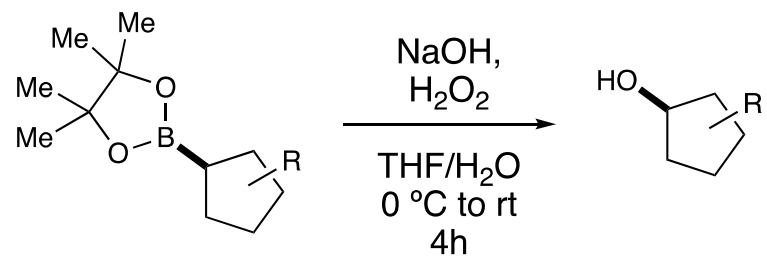

\section{General Procedure E: Oxidation of Alkyl Boronic Esters}

Alkyl boronic ester was dissolved in THF $(3 \mathrm{~mL})$ and cooled to $0{ }^{\circ} \mathrm{C}$ before $\mathrm{NaOH}(2 \mathrm{M}$ aq., $3 \mathrm{~mL})$ and hydrogen peroxide (30\% aq., $3 \mathrm{~mL}$ ) were added. The reaction was allowed to stir at $0{ }^{\circ} \mathrm{C}$ for $4 \mathrm{~h}$. before being carefully quenched with saturated $\mathrm{Na}_{2} \mathrm{~S}_{2} \mathrm{O}_{3}(3 \mathrm{~mL})$. The aqueous layer was extracted with ethyl acetate $(3 \times 5 \mathrm{~mL})$ and the combined organic extracts were dried over $\mathrm{MgSO}_{4}$, 
gravity filtered, and the solvent removed under reduced pressure. The crude material was then purified via silica gel chromatography.

In cases where separation from pinacol is problematic: The crude mixture was dissolved in acetone/ $\mathrm{H}_{2} \mathrm{O}(1: 1,5 \mathrm{~mL})$ before $\mathrm{NaIO}_{4}\left(545 \mathrm{mg}, 2.50 \mathrm{mmol}, 5.00\right.$ equiv.) and $\mathrm{NH}_{4} \mathrm{OAc}$ (197 mg, $2.60 \mathrm{mmol}, 5.20$ equiv.) were added. The mixture was stirred for $2 \mathrm{~h}$. before being quenched with $\mathrm{H}_{2} \mathrm{O}(5 \mathrm{~mL})$. The aqueous layer was extracted with EtOAc $(3 \times 5 \mathrm{~mL})$. The combined organic extracts were dried over $\mathrm{MgSO}_{4}$ and gravity filtered. The solvent was then removed under reduced pressure, and the crude material was then purified via silica gel chromatography.

\section{Characterization Data}

In ${ }^{13} \mathrm{C}$ NMR spectra, signals of carbons directly bonded to boron were not detected because of quadrupolar relaxation.

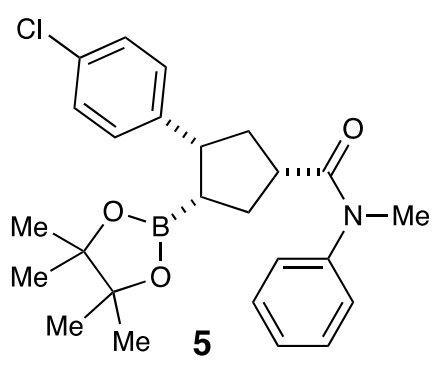

3-(4-chlorophenyl)- $N$-methyl- $N$-phenyl-4-(4,4,5,5-tetramethyl-1,3,2-dioxaborolan-2yl)cyclopentane-1-carboxamide (5): The title compound was prepared according to General Procedure D. NMR yield of the unpurified reaction mixture was determined using 1,3,5trimethylbenzene as an NMR standard. Purification by silica gel column chromatography (Gradient: toluene to 20:1 toluene: acetone) yielded $\mathbf{5}$ as a white solid. Crystals suitable for X-ray analysis were prepared by slow diffusion of pentane into a concentrated solution of $\mathbf{5}$ in dichloromethane.

Average over 2 runs: $151 \mathrm{mg}, 68 \%$ isolated yield

IR (neat): 3065 (w), 2976 (w), 2949 (w), 1647 (s), 1595 (m), 1493 (m), 1413 (s), 1323 (s), 1142 (s) $\mathrm{cm}^{-1}$; ${ }^{1} \mathbf{H}$ NMR (500 MHz, CDCl $): \delta 7.45(\mathrm{t}, J=7.6 \mathrm{~Hz}, 2 \mathrm{H}), 7.37(\mathrm{t}, J=7.4 \mathrm{~Hz}, 1 \mathrm{H}), 7.34-$ $7.28(\mathrm{~m}, 2 \mathrm{H}), 7.27-7.18(\mathrm{~m}, 4 \mathrm{H}), 3.30(\mathrm{~s}, 3 \mathrm{H}), 3.28-3.21(\mathrm{~m}, 1 \mathrm{H}), 2.75-2.64(\mathrm{~m}, 1 \mathrm{H}), 2.28-$ $2.10(\mathrm{~m}, 3 \mathrm{H}), 1.83(\mathrm{dq}, J=13.0,6.7,6.2 \mathrm{~Hz}, 1 \mathrm{H}), 1.60(\mathrm{td}, J=11.0,7.4 \mathrm{~Hz}, 1 \mathrm{H}), 0.92(\mathrm{~d}, J=4.3$ $\mathrm{Hz}, 12 \mathrm{H}) ;{ }^{13} \mathbf{C}$ NMR (126 MHz, CDCl 3$): ~ \delta 175.3,145.0,144.3,131.4,129.9,129.8,127.9,127.8$, 127.5, 82.9, 45.7, 44.2, 38.8, 37.7, 33.7, 24.6, 24.6; HRMS (APCI) m/z: $[\mathrm{M}+\mathrm{H}]^{+}$Calcd for $\mathrm{C}_{25} \mathrm{H}_{32} \mathrm{BClNO}_{3} 440.2158$; Found 440.2157.

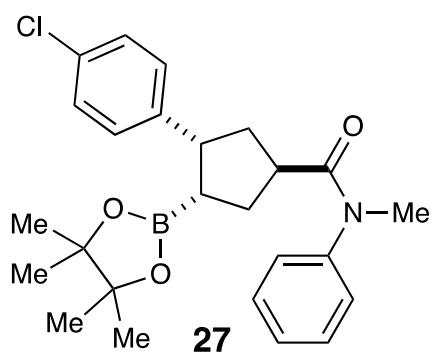

3-(4-chlorophenyl)- $N$-methyl- $N$-phenyl-4-(4,4,5,5-tetramethyl-1,3,2-dioxaborolan-2-

yl)cyclopentane-1-carboxamide (27): The title compound was prepared according to a modified 
version of General Procedure D with DMA as the solvent. NMR yield of the unpurified reaction mixture was determined using 1,3,5-trimethylbenzene as an NMR standard. Purification by silica gel column chromatography (Gradient: toluene to 20:1 toluene: acetone) yielded $\mathbf{3 3}$ as a white solid (48 mg, 22\%, low isolated yield because of difficult separation).

IR (neat): 2976 (m), 2931 (m), 2870 (m), 1650 (s), 1594 (s), 1494 (s), 1371 (s), $1141(\mathrm{~s}) \mathrm{cm}^{-1} ;{ }^{1} \mathbf{H}$ NMR (500 MHz, CDCl $): \delta 7.42(\mathrm{t}, J=7.6 \mathrm{~Hz}, 2 \mathrm{H}), 7.34(\mathrm{t}, J=7.4 \mathrm{~Hz}, 1 \mathrm{H}), 7.21$ (dd, $J=7.4$, $1.7 \mathrm{~Hz}, 2 \mathrm{H}), 7.12(\mathrm{~d}, J=8.1 \mathrm{~Hz}, 2 \mathrm{H}), 7.02(\mathrm{~d}, J=8.1 \mathrm{~Hz}, 2 \mathrm{H}), 3.58(\mathrm{q}, J=7.7 \mathrm{~Hz}, 1 \mathrm{H}), 3.28(\mathrm{~s}$, $3 \mathrm{H}), 3.06(\mathrm{td}, J=9.1,4.6 \mathrm{~Hz}, 1 \mathrm{H}), 2.35(\mathrm{ddd}, J=13.5,8.3,5.7 \mathrm{~Hz}, 1 \mathrm{H}), 2.14-2.00(\mathrm{~m}, 2 \mathrm{H}), 1.91$

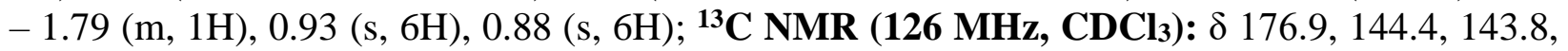
131.2, 129.6, 129.0, 127.8, 127.6, 127.6, 82.8, 46.8, 41.1, 37.6, 37.2, 33.4, 24.6, 24.5; HRMS (+EI) $\mathrm{m} / \mathrm{z}:[\mathrm{M}]^{+}$Calcd for $\mathrm{C}_{25} \mathrm{H}_{31} \mathrm{BClNO}_{3}$ 439.2085; Found 439.2088.

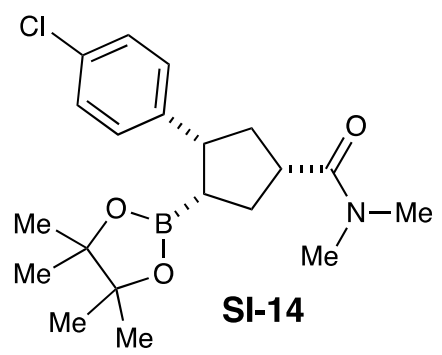

3-(4-chlorophenyl)- $N, N$-dimethyl-4-(4,4,5,5-tetramethyl-1,3,2-dioxaborolan-2-

yl)cyclopentane-1-carboxamide (SI-14): The title compound was prepared according to General Procedure B. NMR yield of the unpurified reaction mixture was determined using 1,3,5trimethylbenzene as an NMR standard. Purification by silica gel column chromatography (Gradient: hexane to 10:1 hexanes: acetone) yielded product as a white solid (81 $\mathrm{mg}, 43 \%$ ).

IR (neat): 2929 (m), 1738 (m), 1646 (s), 1377 (s), 1322 (m), 1139 (s) cm ${ }^{-1} ;{ }^{1}$ H NMR (500 MHz, CDCl $): \delta 7.30-7.25(\mathrm{~m}, 2 \mathrm{H}), 7.21-7.15(\mathrm{~m}, 2 \mathrm{H}), 3.43(\mathrm{dt}, J=9.9,8.0 \mathrm{~Hz}, 1 \mathrm{H}), 3.07(\mathrm{~s}, 3 \mathrm{H})$, 3.02 (ddd, $J=18.2,10.5,7.6 \mathrm{~Hz}, 1 \mathrm{H}), 2.96(\mathrm{~s}, 3 \mathrm{H}), 2.32(\mathrm{dt}, J=13.2,8.0 \mathrm{~Hz}, 1 \mathrm{H}), 2.26-2.09(\mathrm{~m}$, 2H), $2.02(\mathrm{dt}, J=13.3,7.1 \mathrm{~Hz}, 1 \mathrm{H}), 1.82(\mathrm{ddd}, J=11.7,10.2,7.3 \mathrm{~Hz}, 1 \mathrm{H}), 0.91(\mathrm{~d}, J=8.7 \mathrm{~Hz}$, 12H); ${ }^{13} \mathbf{C}$ NMR (126 MHz, CDCl 3$): \delta$ 174.6, 144.8, 131.5, 129.8, 127.9, 82.9, 45.6, 43.5, 37.7, 37.1, 35.7, 32.6, 24.6, 24.6; HRMS (APCI) m/z: $[\mathrm{M}+\mathrm{H}]^{+}$Calcd for $\mathrm{C}_{20} \mathrm{H}_{30} \mathrm{BClNO}_{3}$ 378.2005; Found 378.2012.

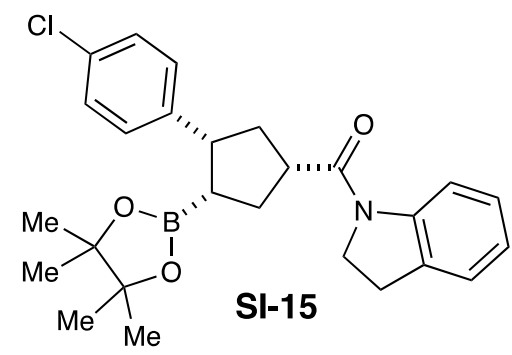

(3-(4-chlorophenyl)-4-(4,4,5,5-tetramethyl-1,3,2-dioxaborolan-2-yl)cyclopentyl)(indolin-1yl)methanone (SI-15): The title compound was prepared according to General Procedure B. NMR yield of the unpurified reaction mixture was determined using 1,3,5-trimethylbenzene as an NMR standard. Purification by silica gel column chromatography (Gradient: hexanes to 50:1 hexanes: acetone) yielded product as a white solid (79 $\mathrm{mg}, 35 \%)$.

IR (neat): 2971 (w), 1738 (m), 1650 (s), 1486 (m), 1408 (s), 1319 (s), 1141 (s), 752 (s) cm ${ }^{-1}$; ${ }^{\mathbf{1}} \mathbf{H}$ NMR (500 MHz, CDCl $): \delta 8.28(\mathrm{~d}, J=8.1 \mathrm{~Hz}, 1 \mathrm{H}), 7.22(\mathrm{dt}, J=13.5,6.8 \mathrm{~Hz}, 6 \mathrm{H}), 7.03(\mathrm{td}, J$ 
$=7.4,1.1 \mathrm{~Hz}, 1 \mathrm{H}), 4.18(\mathrm{td}, J=8.9,5.6 \mathrm{~Hz}, 2 \mathrm{H}), 3.67(\mathrm{q}, J=7.5 \mathrm{~Hz}, 1 \mathrm{H}), 3.36(\mathrm{p}, J=7.7 \mathrm{~Hz}$, $1 \mathrm{H}), 3.22(\mathrm{t}, J=8.5 \mathrm{~Hz}, 2 \mathrm{H}), 2.53(\mathrm{ddd}, J=13.0,7.8,5.3 \mathrm{~Hz}, 1 \mathrm{H}), 2.31-2.21(\mathrm{~m}, 2 \mathrm{H}), 2.18$ (ddd, $J=13.0,8.9,6.8 \mathrm{~Hz}, 1 \mathrm{H}), 2.11(\mathrm{q}, J=8.0 \mathrm{~Hz}, 1 \mathrm{H}), 1.03(\mathrm{~d}, J=18.3 \mathrm{~Hz}, 12 \mathrm{H}) ;{ }^{13} \mathbf{C}$ NMR $(126$ MHz, CDCl 3$): \delta 174.7,143.7,143.4,131.5,131.2,129.2,128.0,127.6,124.5,123.5,117.2,83.0$, 48.1, 46.7, 43.4, 36.6, 31.9, 28.1, 24.7, 24.6; HRMS (ESI) m/z: $[\mathrm{M}+\mathrm{Na}]^{+}$Calcd for $\mathrm{C}_{26} \mathrm{H}_{31} \mathrm{BClNO} 3 \mathrm{Na} 474.1978$; Found 474.1977.

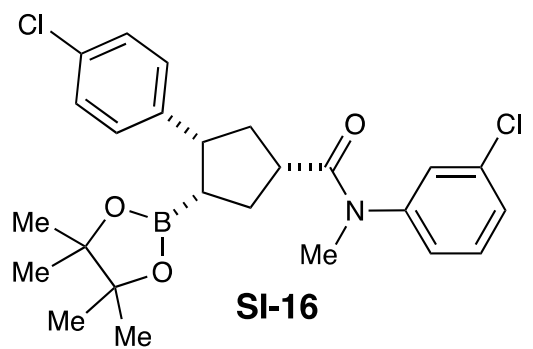

$N$-(3-chlorophenyl)-3-(4-chlorophenyl)- $N$-methyl-4-(4,4,5,5-tetramethyl-1,3,2-

dioxaborolan-2-yl)cyclopentane-1-carboxamide (SI-16): The title compound was prepared according to General Procedure C. NMR yield of the unpurified reaction mixture was determined using 1,3,5-trimethylbenzene as an NMR standard. Purification by silica gel column chromatography (Gradient: hexanes to 10:1 hexanes: acetone) yielded product as a white solid (104 mg, 44\%).

IR (neat): 2971 (w), 1714 (m), 1654 (s), 1589 (m), 1371 (s), 1323 (m), $1141(\mathrm{~m}) \mathrm{cm}^{-1}$; ${ }^{\mathbf{1}} \mathbf{H}$ NMR (500 MHz, CDCl3): $\delta 7.42-7.33(\mathrm{~m}, 2 \mathrm{H}), 7.33-7.27(\mathrm{~m}, 2 \mathrm{H}), 7.25(\mathrm{~d}, J=1.9 \mathrm{~Hz}, 1 \mathrm{H}), 7.23-$ $7.17(\mathrm{~m}, 2 \mathrm{H}), 7.13(\mathrm{dt}, J=7.2,1.9 \mathrm{~Hz}, 1 \mathrm{H}), 3.28(\mathrm{~s}, 3 \mathrm{H}), 2.68(\mathrm{~s}, 1 \mathrm{H}), 2.27-2.09(\mathrm{~m}, 3 \mathrm{H}), 1.93-$ $1.78(\mathrm{~m}, 1 \mathrm{H}), 1.68-1.56(\mathrm{~m}, 1 \mathrm{H}), 1.34-1.23(\mathrm{~m}, 1 \mathrm{H}), 0.92(\mathrm{~d}, J=5.1 \mathrm{~Hz}, 12 \mathrm{H}) ;{ }^{13} \mathbf{C}$ NMR (126 MHz, CDCl3): $\delta 175.1,145.5,144.9,135.1,131.5,130.7,129.9,128.1,127.9,127.8,125.8,82.9$, 45.7, 44.2, 38.8, 37.7, 33.7, 24.6; HRMS (APCI) m/z: $[\mathrm{M}+\mathrm{H}]^{+}$Calcd for $\mathrm{C}_{25} \mathrm{H}_{31} \mathrm{BCl}_{2} \mathrm{NO}_{3}$ 474.1773; Found 474.1778.

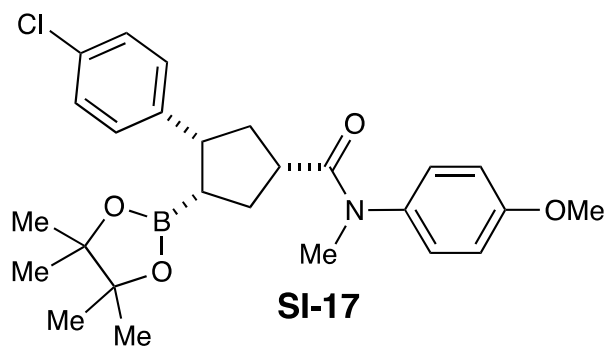

3-(4-chlorophenyl)- $N$-(4-methoxyphenyl)- $N$-methyl-4-(4,4,5,5-tetramethyl-1,3,2-

dioxaborolan-2-yl)cyclopentane-1-carboxamide (SI-17): The title compound was prepared according to General Procedure C. NMR yield of the unpurified reaction mixture was determined using 1,3,5-trimethylbenzene as an NMR standard. Purification by silica gel column chromatography (Gradient: hexanes to 10:1 hexanes: acetone) yielded product as a white solid (134 mg, 57\%).

IR (neat): 2971 (m), 1738 (s), 1650 (s), 1509 (s), 1377 (s), 1247 (s), 837 (m) cm ${ }^{-1} ;{ }^{1}$ H NMR (500 MHz, CDCl3): $\delta 7.29(\mathrm{~d}, J=8.3 \mathrm{~Hz}, 2 \mathrm{H}), 7.23-7.16(\mathrm{~m}, 2 \mathrm{H}), 7.15-7.08(\mathrm{~m}, 2 \mathrm{H}), 6.96-6.89$ $(\mathrm{m}, 2 \mathrm{H}), 3.84(\mathrm{~s}, 3 \mathrm{H}), 3.29-3.20(\mathrm{~m}, 4 \mathrm{H}), 2.74-2.63(\mathrm{~m}, 1 \mathrm{H}), 2.24-2.08(\mathrm{~m}, 3 \mathrm{H}), 1.81(\mathrm{dt}, J=$ 13.4, 7.1 Hz, 1H), 1.59 (ddd, $J=12.0,10.2,7.4 \mathrm{~Hz}, 1 \mathrm{H}), 0.90(\mathrm{~d}, J=4.2 \mathrm{~Hz}, 12 \mathrm{H})$; ${ }^{13} \mathbf{C ~ N M R}$ (126 MHz, CDCl3): $\delta 175.5,158.9,145.1,137.1,131.4,129.9,128.5,127.9,114.8,82.9,55.5$, 
45.7, 44.0, 38.7, 37.8, 33.7, 24.6, 24.6; HRMS (APCI) m/z: $[\mathrm{M}+\mathrm{H}]^{+}$Calcd for $\mathrm{C}_{26} \mathrm{H}_{34} \mathrm{BClNO}_{4}$ 470.2269; Found 470.2274.

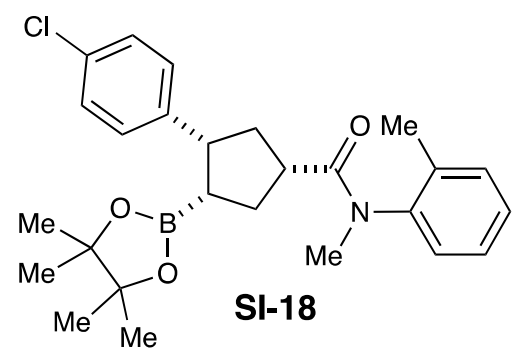

3-(4-chlorophenyl)- $N$-methyl-4-(4,4,5,5-tetramethyl-1,3,2-dioxaborolan-2-yl)- $N$-(otolyl)cyclopentane-1-carboxamide (SI-18): The title compound was prepared according to General Procedure C. NMR yield of the unpurified reaction mixture was determined using 1,3,5trimethylbenzene as an NMR standard. Purification by silica gel column chromatography (Gradient: hexanes to 10:1 hexanes: acetone) yielded product as a white solid (117 $\mathrm{mg}, 51 \%)$.

IR (neat): 2970 (w), 1738 (s), 1650 (s), 1372 (s), 1321 (m), 1216 (s), 1143 (m) cm ${ }^{-1} ;{ }^{1} \mathbf{H}$ NMR $\left(\mathbf{5 0 0} \mathbf{~ M H z}, \mathbf{C D C l}_{3}\right): \delta 7.33-7.20(\mathrm{~m}, 5 \mathrm{H}), 7.18(\mathrm{dd}, J=8.4,1.6 \mathrm{~Hz}, 2 \mathrm{H}), 7.12(\mathrm{ddd}, J=23.4,7.4$, $1.7 \mathrm{~Hz}, 1 \mathrm{H}), 3.28-3.16(\mathrm{~m}, 1 \mathrm{H}), 3.20(\mathrm{~s}, 3 \mathrm{H}), 2.55-2.45(\mathrm{~m}, 1 \mathrm{H}), 2.32-2.21(\mathrm{~m}, 4 \mathrm{H}), 2.12$ (dqd, $J=17.0,12.2,8.0 \mathrm{~Hz}, 2 \mathrm{H}), 1.79$ (ddt, $J=24.2,13.4,7.1 \mathrm{~Hz}, 1 \mathrm{H}$ ), 1.57 (dtd, $J=11.9,9.5$, $7.2 \mathrm{~Hz}, 1 \mathrm{H}), 0.94-0.81(\mathrm{~m}, 12 \mathrm{H}) ;{ }^{13} \mathbf{C}$ NMR (126 MHz, CDCl3, mix of rotomers $): \delta 175.5,175.5$, $145.1,145.0,142.8,142.8,135.6,135.6,131.4,131.4,129.9,129.9,128.3,128.2,127.9,127.4$, 127.3, 82.9, 82.8, 45.8, 45.7, 44.2, 44.0, 39.2, 38.4, 36.2, 36.1, 34.0, 33.2, 24.6, 24.6, 17.5; HRMS (APCI) m/z: $[\mathrm{M}+\mathrm{H}]^{+}$Calcd for $\mathrm{C}_{26} \mathrm{H}_{34} \mathrm{BClNO}_{3} 454.2319$; Found 454.2326.

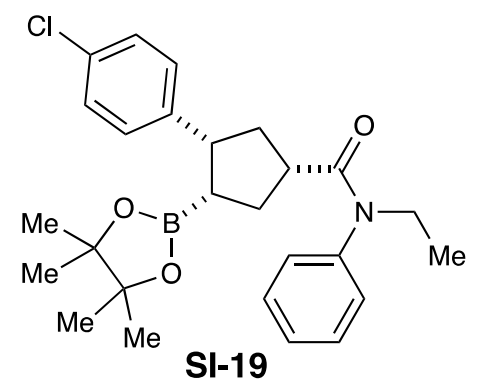

3-(4-chlorophenyl)- $N$-ethyl- $N$-phenyl-4-(4,4,5,5-tetramethyl-1,3,2-dioxaborolan-2-

yl)cyclopentane-1-carboxamide (SI-19): The title compound was prepared according to General Procedure C. NMR yield of the unpurified reaction mixture was determined using 1,3,5trimethylbenzene as an NMR standard. Purification by silica gel column chromatography (Gradient: hexanes to 20:1 hexanes: acetone) yielded product as a white solid (97 $\mathrm{mg}, 43 \%)$.

IR (neat): 2975 (w), 1647 (s), 1594 (m), 1493 (s), 1372 (s), 1258 (s), 1142 (s), 728 (s), 700 (s) $\mathrm{cm}^{-1} ;{ }^{1} \mathbf{H}$ NMR (500 MHz, CDCl$): \delta 7.44(\mathrm{t}, J=7.5 \mathrm{~Hz}, 2 \mathrm{H}), 7.38(\mathrm{t}, J=7.4 \mathrm{~Hz}, 1 \mathrm{H}), 7.31(\mathrm{~d}, J$ $=8.2 \mathrm{~Hz}, 2 \mathrm{H}), 7.22-7.17(\mathrm{~m}, 4 \mathrm{H}), 3.78(\mathrm{qq}, J=13.9,7.2 \mathrm{~Hz}, 2 \mathrm{H}), 3.24(\mathrm{dt}, J=10.2,7.9 \mathrm{~Hz}, 1 \mathrm{H})$, $2.60(\mathrm{tt}, J=10.2,7.4 \mathrm{~Hz}, 1 \mathrm{H}), 2.27-2.09(\mathrm{~m}, 3 \mathrm{H}), 1.82(\mathrm{dt}, J=13.3,7.1 \mathrm{~Hz}, 1 \mathrm{H}), 1.58(\mathrm{ddd}, J=$ 12.1, 10.2, 7.3 Hz, 1H), 1.13 (t, $J=7.1 \mathrm{~Hz}, 3 \mathrm{H}), 0.91(\mathrm{~d}, J=2.7 \mathrm{~Hz}, 12 \mathrm{H}) ;{ }^{13} \mathbf{C}$ NMR (126 MHz, $\left.\mathbf{C D C l}_{3}\right): \delta 174.6,145.1,142.6,131.4,129.9,129.6,128.5,127.9,127.8,82.9,45.7,44.5,44.3$, 38.8, 33.8, 24.6, 24.6, 13.1; HRMS (APCI) m/z: $[\mathrm{M}+\mathrm{H}]^{+}$Calcd for $\mathrm{C}_{26} \mathrm{H}_{34} \mathrm{BClNO}_{3} 454.2319$; Found 454.2326. 


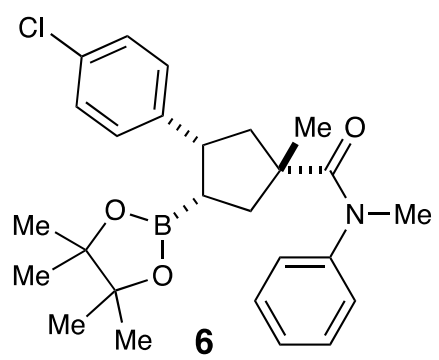

3-(4-chlorophenyl)- $N, 1$-dimethyl- $N$-phenyl-4-(4,4,5,5-tetramethyl-1,3,2-dioxaborolan-2yl)cyclopentane-1-carboxamide (6): The title compound was prepared according to General Procedure D. Purification by silica gel column chromatography (Gradient: toluene to 20:1 toluene: acetone) yielded 6 as a white solid.

Average over 2 runs: $156 \mathrm{mg}, 69 \%$ isolated yield

IR (neat): 2970 (w), 1738 (w), 1628 (s), 1594 (m), 1492 (s), 1356 (s), 1318 (s), 1141 (s) cm ${ }^{-1} ;{ }^{1} \mathbf{H}$ NMR (500 MHz, CDCl3): $\delta 7.40(\mathrm{dd}, J=8.2,6.8 \mathrm{~Hz}, 2 \mathrm{H}), 7.37-7.30(\mathrm{~m}, 1 \mathrm{H}), 7.28-7.22(\mathrm{~m}$, 2H), $7.22-7.16(\mathrm{~m}, 2 \mathrm{H}), 7.15-7.08(\mathrm{~m}, 2 \mathrm{H}), 3.29(\mathrm{~m}, 4 \mathrm{H}), 2.38(\mathrm{t}, J=12.1 \mathrm{~Hz}, 1 \mathrm{H}), 2.25(\mathrm{dd}, J$ $=13.1,9.9 \mathrm{~Hz}, 1 \mathrm{H}), 1.86(\mathrm{td}, J=11.1,7.9 \mathrm{~Hz}, 1 \mathrm{H}), 1.63-1.58(\mathrm{~m}, 1 \mathrm{H}), 1.49(\mathrm{dd}, J=13.1,7.9$ Hz, 1H), 1.23 (s, 3H), 0.96 (s, 6H), 0.87 (s, 6H); ${ }^{13}$ C NMR (126 MHz, CDCl $): \delta$ 177.8, 144.8, 144.3, 131.4, 129.6, 129.2, 128.9, 127.9, 127.7, 82.8, 52.3, 45.7, 44.0, 40.8, 40.6, 25.4, 24.8, 24.4; HRMS (APCI) m/z: [M+H] ${ }^{+}$Calcd for $\mathrm{C}_{26} \mathrm{H}_{34} \mathrm{BCINO}_{3}$ 454.2315; Found 454.2317.

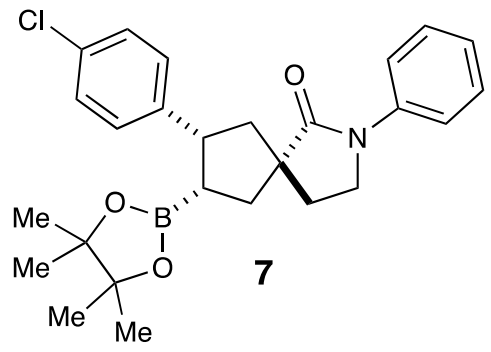

7-(4-chlorophenyl)-2-phenyl-8-(4,4,5,5-tetramethyl-1,3,2-dioxaborolan-2-yl)-2-

azaspiro[4.4]nonan-1-one (7): The title compound was prepared according to General Procedure D. Purification by silica gel column chromatography (Gradient: toluene to 50:1 toluene: acetone) yielded 7 as a white solid.

Average over 2 runs: $53 \mathrm{mg}, 58 \%$ isolated yield

IR (neat): 2972 (w), 2869 (w), 1688 (s), 1490 (m), 1370 (s), 1323 (s), 1141 (s) cm ${ }^{-1}$; ${ }^{\mathbf{1}} \mathbf{H}$ NMR (400 MHz, CDCl3): $\delta 7.65-7.58(\mathrm{~m}, 2 \mathrm{H}), 7.35-7.25(\mathrm{~m}, 4 \mathrm{H}), 7.17-7.12(\mathrm{~m}, 2 \mathrm{H}), 7.07(\mathrm{t}, J=$ $7.4 \mathrm{~Hz}, 1 \mathrm{H}), 3.73(\mathrm{td}, J=6.4,5.7,1.8 \mathrm{~Hz}, 2 \mathrm{H}), 3.54-3.43(\mathrm{~m}, 1 \mathrm{H}), 2.40(\mathrm{dd}, J=13.4,7.9 \mathrm{~Hz}$, $1 \mathrm{H}), 2.31(\mathrm{t}, J=12.6 \mathrm{~Hz}, 1 \mathrm{H}), 2.13-1.95(\mathrm{~m}, 3 \mathrm{H}), 1.92(\mathrm{td}, J=11.2,7.0 \mathrm{~Hz}, 1 \mathrm{H}), 1.76(\mathrm{dd}, J=$ 13.0, $6.8 \mathrm{~Hz}, 1 \mathrm{H}), 0.85(\mathrm{~d}, J=10.0 \mathrm{~Hz}, 12 \mathrm{H}) ;{ }^{13} \mathbf{C}$ NMR (101 MHz, CDCl $): \delta 177.6,144.4$, 139.8, 131.7, 129.9, 128.8, 128.0, 124.3, 119.6, 83.0, 54.1, 45.5, 45.2, 44.4, 38.3, 32.8, 24.6, 24.6; HRMS (APCI) m/z: $[\mathrm{M}+\mathrm{H}]^{+}$Calcd for $\mathrm{C}_{26} \mathrm{H}_{32} \mathrm{BClNO}_{3} 452.2158$; Found 452.2159.

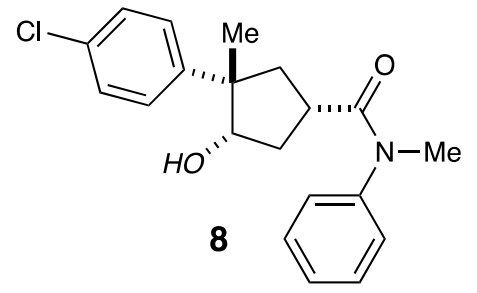


3-(4-chlorophenyl)-4-hydroxy- $N, 3$-dimethyl- $N$-phenylcyclopentane-1-carboxamide (8): The title compound was prepared according to General Procedure D followed by General Procedure E. Purification by silica gel column chromatography (Gradient: toluene to 20:1 toluene: acetone) yielded $\mathbf{8}$ as a white solid.

Average over 2 runs: $91 \mathrm{mg}, 53 \%$ isolated yield (two steps)

IR (neat): 3388 (br), 2969 (w), 1738 (s), 1620 (s), 1591 (s), 1493 (s), 1372 (s), 720 (s) cm ${ }^{-1}$; ${ }^{1} \mathbf{H}$

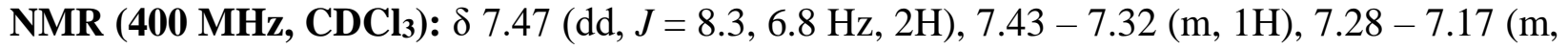
$6 \mathrm{H}), 4.46(\mathrm{~s}, 1 \mathrm{H}, \mathrm{br}), 4.15(\mathrm{~d}, J=4.1 \mathrm{~Hz}, 1 \mathrm{H}), 3.27(\mathrm{~s}, 3 \mathrm{H}), 3.08-2.97(\mathrm{~m}, 1 \mathrm{H}), 2.41(\mathrm{dd}, J=12.7$, $7.3 \mathrm{~Hz}, 1 \mathrm{H}), 2.21(\mathrm{ddd}, J=14.6,10.3,4.2 \mathrm{~Hz}, 1 \mathrm{H}), 2.06-1.90(\mathrm{~m}, 2 \mathrm{H}), 0.96(\mathrm{~s}, 3 \mathrm{H}) ;{ }^{13} \mathbf{C}$ NMR (126 MHz, CDCl3): $\delta$ 178.8, 145.3, 143.9, 131.4, 130.0, 128.5, 128.3, 128.2, 127.2, 79.4, 54.2, 40.3, 38.6, 38.0, 37.0, 28.8; HRMS (APCI) m/z: $[\mathrm{M}+\mathrm{H}]^{+}$Calcd for $\mathrm{C}_{20} \mathrm{H}_{23} \mathrm{ClNO}_{2}$ 344.1412; Found 344.1414.

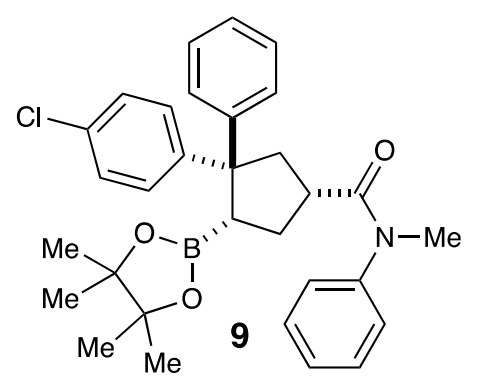

3-(4-chlorophenyl)- $N$-methyl- $N, 3-$ diphenyl-4-(4,4,5,5-tetramethyl-1,3,2-dioxaborolan-2yl)cyclopentane-1-carboxamide (9): The title compound was prepared according to General Procedure D $(0.10 \mathrm{mmol}$ scale). Purification by silica gel column chromatography (Gradient: toluene to 50:1 toluene: acetone) yielded $\mathbf{9}$ as a white solid.

Average over 2 runs: $7.6 \mathrm{mg}, 15 \%$ isolated yield

IR (neat): 2973 (w), 1738 (m), 1651 (s), 1594 (m), 1493 (s), 1363 (s), 1142 (s), 698 (s) cm ${ }^{-1}$; ${ }^{\mathbf{1}} \mathbf{H}$

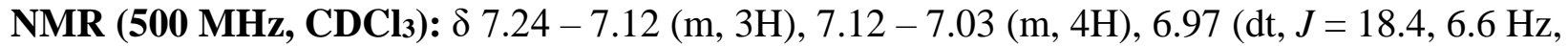
$7 \mathrm{H}), 3.18(\mathrm{~s}, 3 \mathrm{H}), 2.87(\mathrm{t}, J=11.6 \mathrm{~Hz}, 1 \mathrm{H}), 2.50(\mathrm{~s}, 1 \mathrm{H}), 2.22(\mathrm{~s}, 1 \mathrm{H}), 2.17-2.02(\mathrm{~m}, 1 \mathrm{H}), 1.47$ (s, 2H), 0.91 (s, 6H), $0.84(\mathrm{~s}, 6 \mathrm{H}) ;{ }^{13} \mathbf{C}$ NMR (126 MHz, CDCl $)$ : $\delta$ 175.0, 149.1, 147.6, 143.9, 131.3, 129.6, 129.5, 127.8, 127.6, 127.5, 127.2, 126.7, 125.5, 83.0, 57.4, 43.8, 41.1, 37.5, 31.2, 24.5, 24.4; HRMS (APCI) m/z: $[\mathrm{M}+\mathrm{H}]^{+}$Calcd for $\mathrm{C}_{31} \mathrm{H}_{36} \mathrm{BClNO}_{3}$ 516.2477; Found 516.2482.

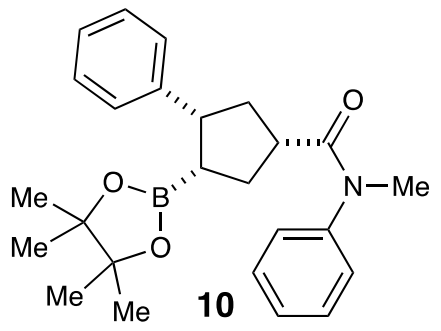

$N$-methyl- $N, 3$-diphenyl-4-(4,4,5,5-tetramethyl-1,3,2-dioxaborolan-2-yl)cyclopentane-1carboxamide (10): The title compound was prepared according to General Procedure D. Purification by silica gel column chromatography (Gradient: toluene to 20:1 toluene: acetone) yielded $\mathbf{1 0}$ as a white solid.

Average over 2 runs: $120 \mathrm{mg}, 59 \%$ isolated yield

IR (neat): 2976 (w), 2872 (w), 1737 (m), 1650 (s), 1593 (m), 1492 (m), 1413 (s), 1379 (s), 1144 (s), $696(\mathrm{~s}) \mathrm{cm}^{-1} ;{ }^{1} \mathbf{H}$ NMR (400 MHz, CDCl$): ~ \delta 7.41(\mathrm{dd}, J=8.3,6.8 \mathrm{~Hz}, 2 \mathrm{H}), 7.37-7.28(\mathrm{~m}$, 
3H), $7.24-7.15(\mathrm{~m}, 4 \mathrm{H}), 7.15-7.04(\mathrm{~m}, 1 \mathrm{H}), 3.27(\mathrm{~m}, 4 \mathrm{H}), 2.69-2.61(\mathrm{~m}, 1 \mathrm{H}), 2.31-2.16(\mathrm{~m}$, $2 \mathrm{H}), 2.11(\mathrm{dt}, J=13.9,7.9 \mathrm{~Hz}, 1 \mathrm{H}), 1.80(\mathrm{dt}, J=13.1,7.1 \mathrm{~Hz}, 1 \mathrm{H}), 1.58(\mathrm{dd}, J=19.4,10.5 \mathrm{~Hz}$, 1H), $0.84(\mathrm{~d}, J=9.4 \mathrm{~Hz}, 12 \mathrm{H}) ;{ }^{13} \mathbf{C}$ NMR (101 MHz, CDCl $): \delta 175.3,146.3,144.3,129.7,127.9$, 127.7, 127.6, 127.5, 125.7, 82.7, 46.3, 44.3, 38.8, 37.6, 33.7, 24.6, 24.6; HRMS (ESI) m/z: $[\mathrm{M}+\mathrm{Na}]^{+}$Calcd for $\mathrm{C}_{25} \mathrm{H}_{32} \mathrm{BNO}_{3} \mathrm{Na} 428.2367$; Found 428.2370.

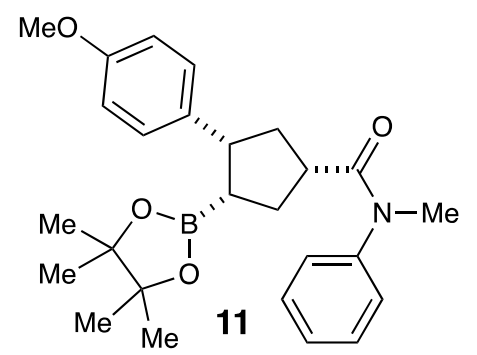

3-(4-methoxyphenyl)- $N$-methyl- $N$-phenyl-4-(4,4,5,5-tetramethyl-1,3,2-dioxaborolan-2yl)cyclopentane-1-carboxamide (11): The title compound was prepared according to General Procedure D. Purification by silica gel column chromatography (Gradient: toluene to 20:1 toluene: acetone) yielded $\mathbf{1 1}$ as a white solid.

Average over 2 runs: $113 \mathrm{mg}, 52 \%$ isolated yield

IR (neat): 2971 (m), 2951 (m), 1738 (m), 1649 (s), $1511(\mathrm{~m}), 1378(\mathrm{~s}), 1248(\mathrm{~s}) \mathrm{cm}^{-1}$; ${ }^{\mathbf{1}} \mathbf{H}$ NMR (400 MHz, CDCls): $\delta 7.40(\mathrm{dd}, J=8.3,6.7 \mathrm{~Hz}, 2 \mathrm{H}), 7.32(\mathrm{t}, J=7.4 \mathrm{~Hz}, 1 \mathrm{H}), 7.28-7.11(\mathrm{~m}, 4 \mathrm{H})$, $6.79-6.71(\mathrm{~m}, 2 \mathrm{H}), 3.72(\mathrm{~s}, 3 \mathrm{H}), 3.26(\mathrm{~s}, 3 \mathrm{H}), 3.24-3.15(\mathrm{~m}, 1 \mathrm{H}), 2.64(\mathrm{dd}, J=12.8,5.7 \mathrm{~Hz}$, $1 \mathrm{H}), 2.31-2.14(\mathrm{~m}, 2 \mathrm{H}), 2.09(\mathrm{dt}, J=13.4,8.1 \mathrm{~Hz}, 1 \mathrm{H}), 1.77(\mathrm{dt}, J=13.2,7.1 \mathrm{~Hz}, 1 \mathrm{H}), 1.54$ (td,

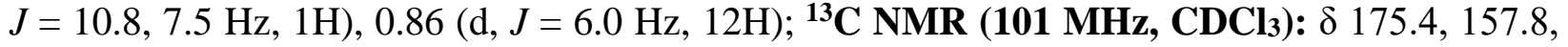
144.4, 138.7, 129.7, 129.4, 127.7, 127.5, 113.3, 82.7, 55.3, 45.5, 44.3, 38.9, 37.6, 33.6, 27.1, 24.6, 24.6; HRMS (ESI) m/z: [M+Na] $]^{+}$Calcd for $\mathrm{C}_{26} \mathrm{H}_{34} \mathrm{BNO}_{4} \mathrm{Na}$ 458.2473; Found 458.2475.

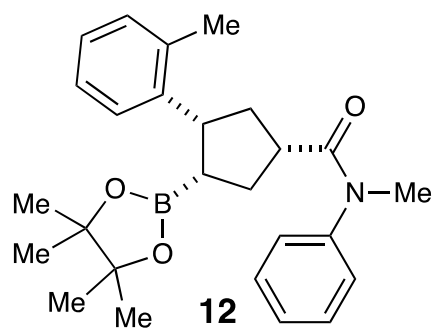

$N$-methyl- $N$-phenyl-3-(4,4,5,5-tetramethyl-1,3,2-dioxaborolan-2-yl)-4-(o-tolyl)cyclopentane1-carboxamide (12): The title compound was prepared according to General Procedure D Purification by silica gel column chromatography (Gradient: toluene to 20:1 toluene: acetone) yielded $\mathbf{1 2}$ as a white solid.

Average over 2 runs: $83 \mathrm{mg}, 40 \%$ isolated yield

IR (neat): 2971 (w), 1738 (m), 1650 (s), 1591 (m), 1374 (s), 1140 (s), 669 (s) cm ${ }^{-1} ;{ }^{\mathbf{1}}$ H NMR (400 MHz, CDCl3): $\delta 7.45(\mathrm{~d}, J=7.8 \mathrm{~Hz}, 1 \mathrm{H}), 7.40(\mathrm{dd}, J=8.3,6.7 \mathrm{~Hz}, 2 \mathrm{H}), 7.37-7.29(\mathrm{~m}, 1 \mathrm{H}), 7.27$ - $7.04(\mathrm{~m}, 3 \mathrm{H}), 7.02-6.93(\mathrm{~m}, 2 \mathrm{H}), 3.36(\mathrm{q}, J=9.5 \mathrm{~Hz}, 1 \mathrm{H}), 3.27(\mathrm{~s}, 3 \mathrm{H}), 2.64(\mathrm{~s}, 1 \mathrm{H}), 2.42-$ $2.29(\mathrm{~m}, 1 \mathrm{H}), 2.24(\mathrm{~s}, 3 \mathrm{H}), 2.23-2.17(\mathrm{~m}, 1 \mathrm{H}), 2.14(\mathrm{~s}, 3 \mathrm{H}), 2.06-1.91(\mathrm{~m}, 1 \mathrm{H}), 1.80(\mathrm{dt}, J=$ 12.9, $7.4 \mathrm{~Hz}, 1 \mathrm{H}), 1.67(\mathrm{q}, J=10.5 \mathrm{~Hz}, 1 \mathrm{H}), 0.84(\mathrm{~s}, 6 \mathrm{H}), 0.77(\mathrm{~s}, 6 \mathrm{H}) ;{ }^{13} \mathrm{C}$ NMR (126 MHz, CDCl$\left._{3}\right): \delta 175.2,144.4,143.6,136.4,129.7,129.6,127.7,127.5,127.4,125.8,125.6,82.7,44.3$, 41.9, 38.1, 37.7, 33.6, 24.7, 24.4, 20.2; HRMS (APCI) m/z: $[\mathrm{M}+\mathrm{H}]^{+}$Calcd for $\mathrm{C}_{26} \mathrm{H}_{35} \mathrm{BNO}_{3}$ 420.2705; Found 420.2703. 


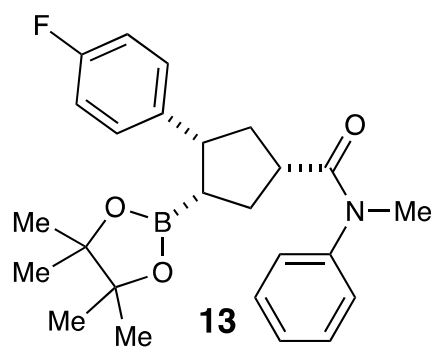

3-(4-fluorophenyl)- $N$-methyl- $N$-phenyl-4-(4,4,5,5-tetramethyl-1,3,2-dioxaborolan-2-

yl)cyclopentane-1-carboxamide (13): The title compound was prepared according to General Procedure D. Purification by silica gel column chromatography (Gradient: toluene to 20:1 toluene: acetone) yielded $\mathbf{1 3}$ as a white solid.

Average over 2 runs: $124 \mathrm{mg}, 59 \%$ isolated yield

IR (neat): 2948 (w), 1646 (s), 1594 (m), 1508 (m), 1372 (s), 1221 (s), 841 (s), 776 (s) cm ${ }^{-1}{ }^{1} \mathbf{H}$ NMR (400 MHz, CDCl3): $\delta 7.40(\mathrm{dd}, J=8.3,6.8 \mathrm{~Hz}, 2 \mathrm{H}), 7.36-7.25(\mathrm{~m}, 3 \mathrm{H}), 7.22-7.14(\mathrm{~m}$, $2 \mathrm{H}), 6.93-6.82(\mathrm{~m}, 2 \mathrm{H}), 3.25(\mathrm{~s}, 3 \mathrm{H}), 3.21(\mathrm{t}, J=8.7 \mathrm{~Hz}, 1 \mathrm{H}), 2.64(\mathrm{p}, J=9.3 \mathrm{~Hz}, 1 \mathrm{H}), 2.25-$ $2.05(\mathrm{~m}, 3 \mathrm{H}), 1.78(\mathrm{dt}, J=13.2,7.1 \mathrm{~Hz}, 1 \mathrm{H}), 1.54(\mathrm{ddd}, J=12.2,9.9,7.2 \mathrm{~Hz}, 1 \mathrm{H}), 0.86(\mathrm{~d}, J=3.2$ $\mathrm{Hz}, 12 \mathrm{H}) ;{ }^{13} \mathbf{C}$ NMR (101 MHz, CDCl $): \delta 175.3,161.3\left(\mathrm{C}-\mathrm{F},{ }^{1} \mathrm{~J}_{\mathrm{C}-\mathrm{F}}=242 \mathrm{~Hz}\right), 144.3,142.2$, $129.85\left(\mathrm{C}-\mathrm{F},{ }^{3} \mathrm{~J}_{\mathrm{C}-\mathrm{F}}=7.7 \mathrm{~Hz}\right), 129.7,127.7,127.4,114.4\left(\mathrm{C}-\mathrm{F},{ }^{2} \mathrm{~J}_{\mathrm{C}-\mathrm{F}}=20.9 \mathrm{~Hz}\right), 82.8,45.5,44.1$, 39.0, 37.6, 33.6, 24.6; ${ }^{19} \mathbf{F}$ NMR (376 MHz, CDCl3): $\delta-118.23(\mathrm{td}, J=8.9,4.4 \mathrm{~Hz})$; HRMS (APCI) m/z: $[\mathrm{M}+\mathrm{H}]^{+}$Calcd for $\mathrm{C}_{25} \mathrm{H}_{32} \mathrm{BFNO}_{3} 424.2458$; Found 424.2464.

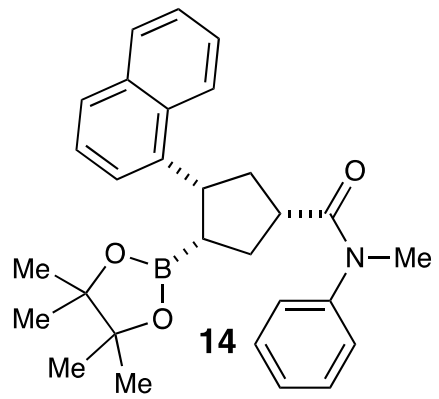

$N$-methyl-3-(naphthalen-1-yl)- $N$-phenyl-4-(4,4,5,5-tetramethyl-1,3,2-dioxaborolan-2-

yl)cyclopentane-1-carboxamide (14): The title compound was prepared according to General Procedure D. NMR yield of the unpurified reaction mixture was determined using 1,3,5trimethylbenzene as an NMR standard. Purification by silica gel column chromatography (10:1 hexanes: acetone) yielded $\mathbf{1 4}$ as a white solid.

Average over 2 runs: $116 \mathrm{mg}, 51 \%$ isolated yield

IR (neat): 3050 (s), 2974 (s), 1647 (s), 1370 (s), 1140 (s), 779 (s), 669 (s) cm ${ }^{-1}$; ${ }^{1}$ H NMR (600 MHz, CDCl3): $\delta 8.00(\mathrm{~d}, J=8.5 \mathrm{~Hz}, 1 \mathrm{H}), 7.76(\mathrm{dd}, J=7.9,1.5 \mathrm{~Hz}, 1 \mathrm{H}), 7.67(\mathrm{~d}, J=7.2 \mathrm{~Hz}, 1 \mathrm{H})$, $7.63(\mathrm{~d}, J=8.1 \mathrm{~Hz}, 1 \mathrm{H}), 7.47-7.34(\mathrm{~m}, 7 \mathrm{H}), 7.24(\mathrm{t}, J=1.2 \mathrm{~Hz}, 1 \mathrm{H}), 3.98(\mathrm{q}, J=9.2 \mathrm{~Hz}, 1 \mathrm{H})$, $3.31(\mathrm{~s}, 3 \mathrm{H}), 2.82-2.76(\mathrm{~m}, 1 \mathrm{H}), 2.60(\mathrm{q}, J=11.0 \mathrm{~Hz}, 1 \mathrm{H}), 2.30-2.21(\mathrm{~m}, 1 \mathrm{H}), 2.13(\mathrm{p}, J=6.7$ $\mathrm{Hz}, 1 \mathrm{H}), 1.90(\mathrm{~h}, J=7.9 \mathrm{~Hz}, 2 \mathrm{H}), 0.67(\mathrm{~s}, 6 \mathrm{H}), 0.52(\mathrm{~s}, 6 \mathrm{H}) ;{ }^{13} \mathrm{C}$ NMR (151 MHz, CDCl $): \delta$ $175.2,144.3,140.9,133.7,132.3,129.8,128.4,127.8,127.5,126.3,125.4,125.4,125.0,124.4$, 124.3, 82.5, 44.0, 41.4, 37.8, 37.7, 33.7, 24.3, 24.2; HRMS (APCI) m/z: $[\mathrm{M}+\mathrm{H}]^{+}$Calcd for $\mathrm{C}_{29} \mathrm{H}_{35} \mathrm{BNO}_{3} 456.2705$; Found 456.2704. 


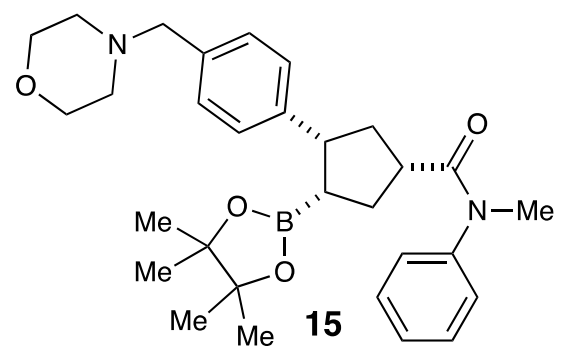

$N$-methyl-3-(4-(morpholinomethyl)phenyl)- $N$-phenyl-4-(4,4,5,5-tetramethyl-1,3,2-

dioxaborolan-2-yl)cyclopentane-1-carboxamide (15): The title compound was prepared according to General Procedure D. NMR yield of the unpurified reaction mixture was determined using 1,3,5-trimethylbenzene as an NMR standard. Purification by silica gel column chromatography (Gradient: 2:1 to 1.5:1 DCM: acetone) yielded 15 as a white solid.

Average over 2 runs: $161 \mathrm{mg}, 64 \%$ isolated yield

IR (neat): 2972 (m), 2762 (s), 1651 (s), 1372 (s), 1115 (s), 700 (s) cm ${ }^{-1} ;{ }^{\mathbf{1}} \mathbf{H}$ NMR (600 MHz, CDCl3): $\delta 7.40(\mathrm{t}, J=7.6 \mathrm{~Hz}, 2 \mathrm{H}), 7.33(\mathrm{t}, J=7.4 \mathrm{~Hz}, 1 \mathrm{H}), 7.27(\mathrm{~d}, J=7.8 \mathrm{~Hz}, 2 \mathrm{H}), 7.21-7.18$ $(\mathrm{m}, 2 \mathrm{H}), 7.15(\mathrm{~d}, J=7.8 \mathrm{~Hz}, 2 \mathrm{H}), 3.65(\mathrm{t}, J=4.6 \mathrm{~Hz}, 4 \mathrm{H}), 3.41(\mathrm{~s}, 2 \mathrm{H}), 3.27(\mathrm{~s}, 3 \mathrm{H}), 3.23(\mathrm{q}, J=$ $8.8 \mathrm{~Hz}, 1 \mathrm{H}), 2.64(\mathrm{dq}, J=10.5,7.3,5.1 \mathrm{~Hz}, 1 \mathrm{H}), 2.39$ (q, $J=8.2,4.7 \mathrm{~Hz}, 4 \mathrm{H}), 2.27-2.17(\mathrm{~m}$, 2H), $2.10(\mathrm{dt}, J=13.6,7.9 \mathrm{~Hz}, 1 \mathrm{H}), 1.80(\mathrm{dt}, J=13.2,6.9 \mathrm{~Hz}, 1 \mathrm{H}), 1.58(\mathrm{td}, J=11.1,7.6 \mathrm{~Hz}, 1 \mathrm{H})$, $0.85(\mathrm{~d}, J=14.7 \mathrm{~Hz}, 12 \mathrm{H}) ;{ }^{13} \mathbf{C}$ NMR (126 MHz, CDCl3): $\delta 175.3,145.3,144.4,134.8,129.7$, $128.9,128.4,127.7,127.5,82.7,66.9,63.1,53.4,46.0,44.3,38.8,37.7,33.7,24.6,24.6$; HRMS (APCI) m/z: $[\mathrm{M}+\mathrm{H}]^{+}$Calcd for $\mathrm{C}_{30} \mathrm{H}_{42} \mathrm{BN}_{2} \mathrm{O}_{4}$ 505.3232; Found 505.3227.

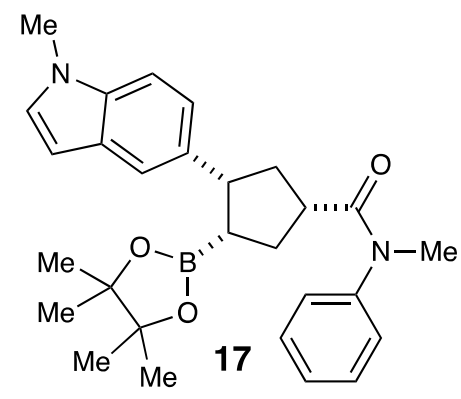

$N$-methyl-3-(1-methyl-1H-indol-5-yl)- $N$-phenyl-4-(4,4,5,5-tetramethyl-1,3,2-dioxaborolan2-yl)cyclopentane-1-carboxamide (17): The title compound was prepared according to General Procedure D. NMR yield of the unpurified reaction mixture was determined using 1,3,5trimethylbenzene as an NMR standard. Purification by silica gel column chromatography (6:1 hexanes: acetone) yielded $\mathbf{1 7}$ as a white solid.

Average over 2 runs: $167 \mathrm{mg}, 73 \%$ isolated yield

IR (neat): 2973 (s), 1650 (s), 1372 (s), 1142 (s), 701 (s) $\mathrm{cm}^{-1} ;{ }^{\mathbf{1}} \mathbf{H}$ NMR (600 MHz, CDCl 3$): \delta$ $7.53(\mathrm{~d}, J=1.6 \mathrm{~Hz}, 1 \mathrm{H}), 7.42(\mathrm{t}, J=7.7 \mathrm{~Hz}, 2 \mathrm{H}), 7.34(\mathrm{t}, J=7.5 \mathrm{~Hz}, 1 \mathrm{H}), 7.21$ (ddd, $J=10.4,7.8$, $1.6 \mathrm{~Hz}, 3 \mathrm{H}), 7.15(\mathrm{~d}, J=8.4 \mathrm{~Hz}, 1 \mathrm{H}), 6.95(\mathrm{~d}, J=2.9 \mathrm{~Hz}, 1 \mathrm{H}), 6.36(\mathrm{~d}, J=3.0 \mathrm{~Hz}, 1 \mathrm{H}), 3.72(\mathrm{~s}$, $3 \mathrm{H}), 3.40-3.32(\mathrm{~m}, 1 \mathrm{H}), 3.29(\mathrm{~s}, 3 \mathrm{H}), 2.66(\mathrm{~d}, J=7.3 \mathrm{~Hz}, 1 \mathrm{H}), 2.40-2.25(\mathrm{~m}, 2 \mathrm{H}), 2.15(\mathrm{dt}, J=$ 14.0, 7.6 Hz, 1H), 1.82 (dt, $J=13.4,7.4 \mathrm{~Hz}, 1 \mathrm{H}), 1.72-1.55(\mathrm{~m}, 1 \mathrm{H}), 0.78(\mathrm{~s}, 6 \mathrm{H}), 0.71(\mathrm{~s}, 6 \mathrm{H})$; ${ }^{13}$ C NMR (151 MHz, CDCl3): $\delta$ 175.4, 144.4, 137.0, 135.6, 129.7, 128.5, 128.4, 127.6, 127.5, 122.6, 120.0, 108.4 100.7, 82.5, 46.4, 44.5, 39.5, 37.7, 33.8, 32.8, 24.6, 24.5; HRMS (APCI) m/z: $[\mathrm{M}+\mathrm{H}]^{+}$Calcd for $\mathrm{C}_{28} \mathrm{H}_{36} \mathrm{BN}_{2} \mathrm{O}_{3} 459.2813$; Found 459.2821. 


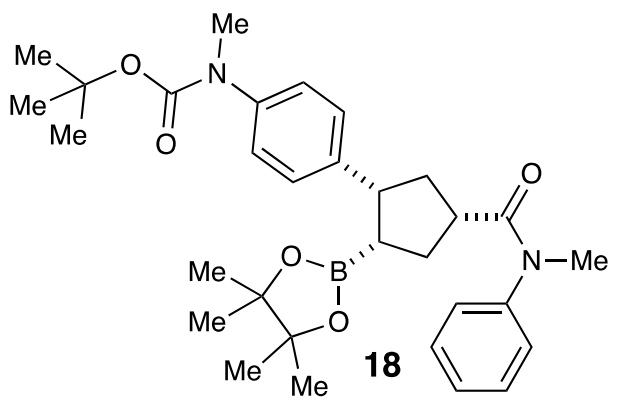

tert-butyl

methyl(4-(4-(methyl(phenyl)carbamoyl)-2-(4,4,5,5-tetramethyl-1,3,2dioxaborolan-2-yl)cyclopentyl)phenyl)carbamate (18): The title compound was prepared according to General Procedure D. NMR yield of the unpurified reaction mixture was determined using 1,3,5-trimethylbenzene as an NMR standard. Purification by silica gel column chromatography (6:1 hexanes: acetone) yielded 18 as a white solid.

Average over 2 runs: $171 \mathrm{mg}, 64 \%$ isolated yield

IR (neat): 2976 (s), 2872 (s), 1698 (s), 1652 (s), 1365 (s), 704 (s) cm ${ }^{-1}$; ${ }^{1}$ H NMR (600 MHz, CDCl $): \delta 7.38(\mathrm{t}, J=7.7 \mathrm{~Hz}, 2 \mathrm{H}), 7.30(\mathrm{t}, J=7.5 \mathrm{~Hz}, 1 \mathrm{H}), 7.24(\mathrm{~d}, J=8.3 \mathrm{~Hz}, 2 \mathrm{H}), 7.19-7.11$ $(\mathrm{m}, 2 \mathrm{H}), 7.02(\mathrm{~d}, J=8.0 \mathrm{~Hz}, 2 \mathrm{H}), 3.24(\mathrm{~s}, 3 \mathrm{H}), 3.20(\mathrm{~d}, J=9.2 \mathrm{~Hz}, 1 \mathrm{H}), 3.13(\mathrm{~s}, 3 \mathrm{H}), 2.62(\mathrm{td}, J=$ $10.5,5.3 \mathrm{~Hz}, 1 \mathrm{H}), 2.19(\mathrm{qd}, J=11.9,10.3,4.6 \mathrm{~Hz}, 2 \mathrm{H}), 2.08(\mathrm{dt}, J=13.4,8.1 \mathrm{~Hz}, 1 \mathrm{H}), 1.77(\mathrm{dt}, J$ $=13.6,7.2 \mathrm{~Hz}, 1 \mathrm{H}), 1.55(\mathrm{td}, J=11.2,7.6 \mathrm{~Hz}, 1 \mathrm{H}), 1.38(\mathrm{~s}, 9 \mathrm{H}), 0.85(\mathrm{~d}, J=7.6 \mathrm{~Hz}, 12 \mathrm{H}) ;{ }^{13} \mathbf{C}$ NMR (151 MHz, CDCl $)$ : $\delta$ 218.0, 175.3, 154.7, 144.3, 143.4, 141.6, 129.7, 128.5, 127.4, 124.8, 82.7 79.9, 45.7, 44.2 , 38.7 , 37.6, 37.4, 33.6, 28.3, 28.3, 24.6; HRMS (APCI) m/z: [M+H] ${ }^{+}$Calcd for $\mathrm{C}_{31} \mathrm{H}_{44} \mathrm{BN}_{2} \mathrm{O}_{5}$ 535.3338; Found 535.3339.

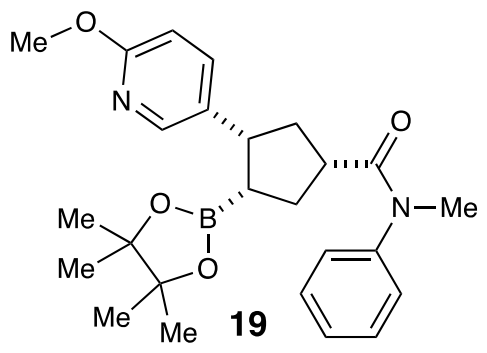

3-(6-methoxypyridin-3-yl)- $N$-methyl- $N$-phenyl-4-(4,4,5,5-tetramethyl-1,3,2-dioxaborolan-2yl)cyclopentane-1-carboxamide (19): The title compound was prepared according to General Procedure D. NMR yield of the unpurified reaction mixture was determined using 1,3,5trimethylbenzene as an NMR standard. Purification by silica gel column chromatography (6:1 hexanes: acetone) yielded $\mathbf{1 9}$ as a white solid.

Average over 2 runs: $188 \mathrm{mg}, 68 \%$ isolated yield

IR (neat): 2975 (s), 1650 (s), 1493 (s), 1142 (s), 699 (s) cm ${ }^{-1} ;{ }^{\mathbf{1}} \mathbf{H}$ NMR (400 MHz, CDCl $): \delta$ $7.95(\mathrm{~d}, J=2.5 \mathrm{~Hz}, 1 \mathrm{H}), 7.72(\mathrm{dd}, J=8.6,2.5 \mathrm{~Hz}, 1 \mathrm{H}), 7.37(\mathrm{t}, J=7.5 \mathrm{~Hz}, 2 \mathrm{H}), 7.31(\mathrm{~d}, J=7.2$ $\mathrm{Hz}, 1 \mathrm{H}), 7.16(\mathrm{~d}, J=7.6 \mathrm{~Hz}, 2 \mathrm{H}), 6.62(\mathrm{~d}, J=8.6 \mathrm{~Hz}, 1 \mathrm{H}), 3.81(\mathrm{~s}, 3 \mathrm{H}), 3.23(\mathrm{~s}, 3 \mathrm{H}), 3.18(\mathrm{~d}, J=$ $8.7 \mathrm{~Hz}, 1 \mathrm{H}), 2.67-2.56(\mathrm{~m}, 1 \mathrm{H}), 2.26(\mathrm{~s}, 1 \mathrm{H}), 2.13-2.03(\mathrm{~m}, 2 \mathrm{H}), 1.77(\mathrm{dt}, J=13.3,7.0 \mathrm{~Hz}, 1 \mathrm{H})$, $1.52(\mathrm{td}, J=10.9,7.4 \mathrm{~Hz}, 1 \mathrm{H}), 0.86(\mathrm{~d}, J=2.9 \mathrm{~Hz}, 12 \mathrm{H}) ;{ }^{13} \mathbf{C}$ NMR (101 MHz, CDCl 3$): \delta 175.3$, $162.6,146.1,144.2,138.9,134.5,129.7,127.7,127.3,110.0,82.9,53.3,44.0,42.8,38.5,37.6$, 33.6, 24.6, 24.5; HRMS (ESI+) m/z: $[\mathrm{M}+\mathrm{H}]^{+}$Calcd for $\mathrm{C}_{25} \mathrm{H}_{34} \mathrm{BN}_{2} \mathrm{O}_{4}$ 437.2606; Found 437.2612. 


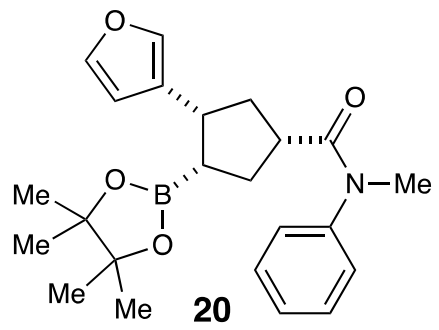

3-(furan-3-yl)- $N$-methyl- $N$-phenyl-4-(4,4,5,5-tetramethyl-1,3,2-dioxaborolan-2-

yl)cyclopentane-1-carboxamide (20): The title compound was prepared according to General Procedure D. NMR yield of the unpurified reaction mixture was determined using 1,3,5trimethylbenzene as an NMR standard. Purification by silica gel column chromatography (6:1 hexanes: acetone) yielded $\mathbf{2 0}$ as a clear oil.

Average over 2 runs: $158 \mathrm{mg}, 80 \%$ isolated yield

IR (neat): 2950 (s), 1649 (s), 1373 (s), 1142 (s), 708 (s) cm ${ }^{-1} ;{ }^{1} \mathbf{H}$ NMR (600 MHz, CDCl3): $\delta$ $7.38(\mathrm{t}, J=7.7 \mathrm{~Hz}, 2 \mathrm{H}), 7.31(\mathrm{dd}, J=7.2,4.4 \mathrm{~Hz}, 2 \mathrm{H}), 7.22(\mathrm{t}, J=1.7 \mathrm{~Hz}, 1 \mathrm{H}), 7.21-7.14(\mathrm{~m}$, $2 \mathrm{H}), 6.48(\mathrm{~d}, J=1.7 \mathrm{~Hz}, 1 \mathrm{H}), 3.24(\mathrm{~s}, 3 \mathrm{H}), 3.15(\mathrm{q}, J=8.0 \mathrm{~Hz}, 1 \mathrm{H}), 2.65-2.56(\mathrm{~m}, 1 \mathrm{H}), 2.11(\mathrm{q}$, $J=12.0 \mathrm{~Hz}, 1 \mathrm{H}), 2.03(\mathrm{dq}, J=9.0,4.2,2.3 \mathrm{~Hz}, 2 \mathrm{H}), 1.75(\mathrm{dt}, J=13.2,7.0 \mathrm{~Hz}, 1 \mathrm{H}), 1.44-1.37$

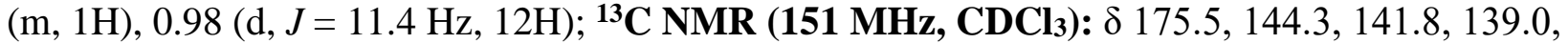
129.7, 129.3, 127.7, 127.4, 111.5, 82.8, 77.3, 77.1, 76.9, 43.7, 38.4, 37.6, 36.6, 33.2, 24.7, 24.6; HRMS (APCI) m/z: $[\mathrm{M}+\mathrm{H}]^{+}$Calcd for $\mathrm{C}_{23} \mathrm{H}_{31} \mathrm{BNO}_{4}$ 396.2341; Found 396.2345.

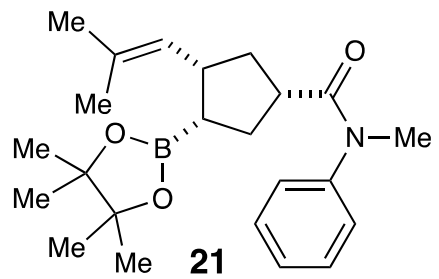

$N$-methyl-3-(2-methylprop-1-en-1-yl)- $N$-phenyl-4-(4,4,5,5-tetramethyl-1,3,2-dioxaborolan2-yl)cyclopentane-1-carboxamide (21): The title compound was prepared according to General Procedure D. NMR yield of the unpurified reaction mixture was determined using 1,3,5trimethylbenzene as an NMR standard. Purification by silica gel column chromatography (8:1 hexanes: acetone) yielded $\mathbf{2 1}$ as a clear oil.

Average over 2 runs: $157 \mathrm{mg}, 82 \%$ isolated yield

IR (neat): 2976 (s), 1647 (s), 1373 (s), 1142 (s), 750 (s) cm ${ }^{-1} ;{ }^{\mathbf{1}} \mathbf{H}$ NMR (600 MHz, CDCl $): \delta$ $7.39(\mathrm{t}, J=7.5 \mathrm{~Hz}, 2 \mathrm{H}), 7.31(\mathrm{t}, J=7.4 \mathrm{~Hz}, 1 \mathrm{H}), 7.20-7.14(\mathrm{~m}, 2 \mathrm{H}), 5.28(\mathrm{dd}, J=10.4,2.3 \mathrm{~Hz}$, $1 \mathrm{H}), 3.23(\mathrm{~s}, 3 \mathrm{H}), 2.86(\mathrm{p}, J=7.9 \mathrm{~Hz}, 1 \mathrm{H}), 2.53(\mathrm{p}, J=8.7 \mathrm{~Hz}, 1 \mathrm{H}), 2.00(\mathrm{q}, J=11.8 \mathrm{~Hz}, 1 \mathrm{H})$, 1.80 (dt, $J=15.7,8.2 \mathrm{~Hz}, 1 \mathrm{H}), 1.69$ (ddt, $J=20.6,13.2,7.2 \mathrm{~Hz}, 2 \mathrm{H}), 1.61$ (s, 3H), 1.53 (s, 3H), $1.32-1.24(\mathrm{~m}, 1 \mathrm{H}), 1.16(\mathrm{~d}, J=5.3 \mathrm{~Hz}, 12 \mathrm{H}) ;{ }^{13} \mathbf{C}$ NMR (151 MHz, CDCl $): \delta$ 175.8, 144.4, 129.6, 129.5, 129.2, 127.6, 127.5, 82.9, 44.0, 39.6, 38.6, 37.7, 33.2, 25.8, 24.9, 24.8, 18.0; HRMS (APCI) $\mathrm{m} / \mathrm{z}$ : $[\mathrm{M}+\mathrm{H}]^{+}$Calcd for $\mathrm{C}_{23} \mathrm{H}_{35} \mathrm{BNO}_{3}$ 384.2705; Found 384.2705. 


\section{- Further Functionalization:}

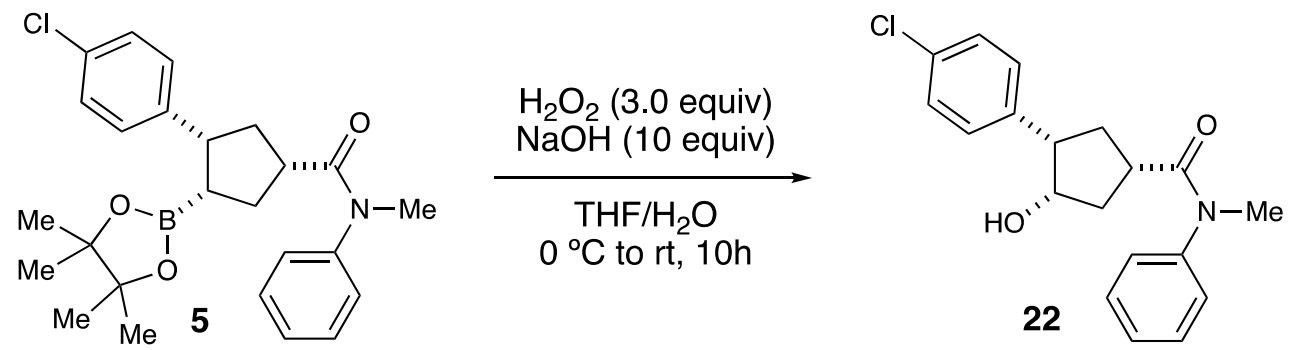

3-(4-chlorophenyl)-4-hydroxy- $N$-methyl- $N$-phenylcyclopentane-1-carboxamide (22): A $25 \mathrm{~mL}$ round-bottom flask was charged with 5 (220 mg, $0.50 \mathrm{mmol}, 1.0$ equiv.), THF (5.0 mL) and $\mathrm{NaOH}$ (2.5 mL, 2.0 M aqueous solution, $5.0 \mathrm{mmol}, 10$ equiv.). The reaction flask was placed in an ice bath and cooled to $0{ }^{\circ} \mathrm{C}$, then, $\mathrm{H}_{2} \mathrm{O}_{2}(0.150 \mathrm{~mL}, 30 \%$ aqueous solution, $1.35 \mathrm{mmol}, 3.00$ equiv.) was added via syringe. The ice bath was removed and the solution was stirred at room temperature for 10 hours then quenched upon the addition of water $(5 \mathrm{~mL})$. The aqueous layer was extracted with EtOAc $(3 \times 10 \mathrm{~mL})$ and the combined organic layers were dried over anhydrous $\mathrm{MgSO}_{4}$, gravity filtered, and concentrated under reduced pressure. Purification by silica gel column chromatography $(2: 1$ hexanes:EtOAc) yielded a clear oil. To remove the small amount of pinacol mixed in the product, the mixture was reacted with $\mathrm{NaIO}_{4}(107 \mathrm{mg}, 0.5 \mathrm{mmol}, 1.0$ equiv.) and $\mathrm{NH}_{4} \mathrm{OAc}(39 \mathrm{mg}, 0.5 \mathrm{mmol}, 1.0$ equiv.) in acetone $(2 \mathrm{~mL})$ and water $(2 \mathrm{~mL})$ at room temperature for $15 \mathrm{~min}$. The resulting mixture was washed with water $(2 \mathrm{~mL})$ and extracted with EtOAc $(3 \times 10 \mathrm{~mL})$, the combined organic layers were dried over anhydrous $\mathrm{MgSO}_{4}$, gravity filtered, concentrated under reduced pressure to yield 22 as a white solid (148 $\mathrm{mg}, 90 \%$ yield).

IR (neat): 3256 (br), 2931 (s), 1622 (s), 1493 (s), 670 (s) cm ${ }^{-1} ;{ }^{1} \mathbf{H}$ NMR (400 MHz, CDCl3): $\delta$ $7.48-7.40(\mathrm{~m}, 2 \mathrm{H}), 7.40-7.32(\mathrm{~m}, 1 \mathrm{H}), 7.29-7.15(\mathrm{~m}, 6 \mathrm{H}), 4.67-4.19(\mathrm{~m}, 1 \mathrm{H}), 4.16(\mathrm{t}, J=$ $3.7 \mathrm{~Hz}, 1 \mathrm{H}), 3.29(\mathrm{~s}, 3 \mathrm{H}), 3.02-2.90(\mathrm{~m}, 1 \mathrm{H}), 2.83(\mathrm{ddd}, J=12.0,8.3,3.2 \mathrm{~Hz}, 1 \mathrm{H}), 2.24-2.02$ $(\mathrm{m}, 3 \mathrm{H}), 1.92$ (ddd, $J=14.2,10.2,4.1 \mathrm{~Hz}, 1 \mathrm{H}) ;{ }^{13} \mathbf{C}$ NMR (101 MHz, CDCl 3$): \delta 178.9,143.8$, 138.4, 132.0, 130.0, 130.0, 128.2, 128.1, 127.2, 75.6, 52.1, 39.2, 39.0, 37.9, 34.9; HRMS (APCI+) $\mathrm{m} / \mathrm{z}:[\mathrm{M}+\mathrm{H}]^{+}$Calcd for $\mathrm{C}_{19} \mathrm{H}_{21} \mathrm{O}_{2} \mathrm{NCl} 330.1255$; Found 330.1254 .
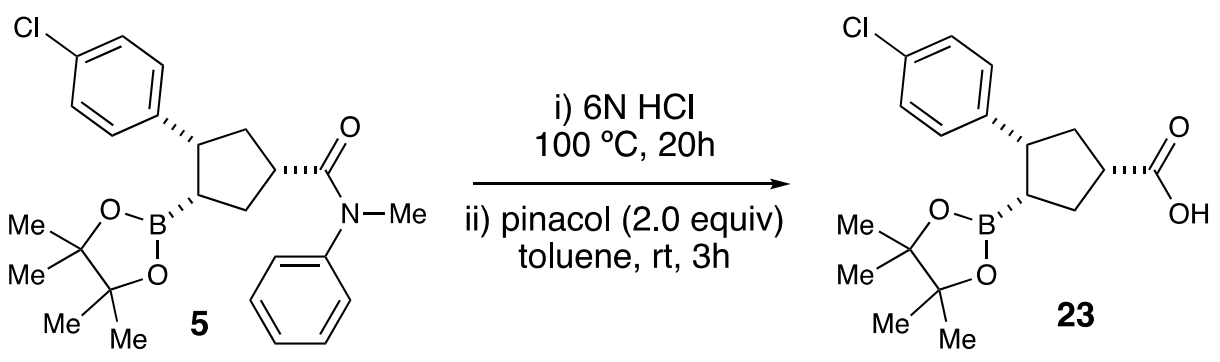

3-(4-chlorophenyl)-4-(4,4,5,5-tetramethyl-1,3,2-dioxaborolan-2-yl)cyclopentane-1-

carboxylic acid (23): To a 16 x $100 \mathrm{~mm}$ screw-capped vial was added $\mathbf{5}$ (130 mg, $0.30 \mathrm{mmol}, 1.0$ equiv.) and $\mathrm{HCl}(2.0 \mathrm{~mL}, 6 \mathrm{M}$ aqueous solution) The vial was capped and stirred vigorously in a preheated oil bath at $100{ }^{\circ} \mathrm{C}$ for $20 \mathrm{~h}$. The reaction mixture was then allowed to cool to room temperature, diluted with $\mathrm{H}_{2} \mathrm{O}(10 \mathrm{~mL})$ and extracted with ethyl acetate $(3 \times 5 \mathrm{~mL})$. The combined organic fractions were washed with brine $(10 \mathrm{~mL})$, dried over $\mathrm{MgSO}_{4}$ and concentrated under reduced pressure. To the resulting oil was added pinacol $(71 \mathrm{mg}, 0.60 \mathrm{mmol}, 2.00$ equiv.) and toluene $(3.0 \mathrm{~mL})$. The mixture was stirred at room temperature for $3 \mathrm{~h}$. Volatile components were 
removed under reduced pressure and purified via silica gel column chromatography (10:3 hexanes: acetone) to provide 23 as a white solid (73 mg, 69\%). Crystals suitable for X-ray analysis were prepared by slow diffusion of pentane into a concentrated solution of $\mathbf{2 3}$ in dichloromethane.

IR (neat): 3052 (br), 2978 (s), 1702 (s), 1379 (s), 1142 (s), 737 (s) cm ${ }^{-1}$; ${ }^{\mathbf{1}}$ H NMR (600 MHz, CDCl$\left._{3}\right): \delta 7.23-7.20(\mathrm{~m}, 4 \mathrm{H}), 3.41(\mathrm{q}, J=8.9 \mathrm{~Hz}, 1 \mathrm{H}), 2.94(\mathrm{p}, J=9.2 \mathrm{~Hz}, 1 \mathrm{H}), 2.46(\mathrm{dt}, J=$ $11.9,8.0 \mathrm{~Hz}, 1 \mathrm{H}), 2.24-2.15(\mathrm{~m}, 3 \mathrm{H}), 1.89(\mathrm{q}, J=9.1 \mathrm{~Hz}, 1 \mathrm{H}), 0.96(\mathrm{~s}, 6 \mathrm{H}), 0.91(\mathrm{~s}, 6 \mathrm{H}) ;{ }^{13} \mathrm{C}$ NMR (126 MHz, CDCl3): $\delta$ 180.9, 143.6, 131.8, 129.5, 128.1, 83.2, 46.0, 45.0, 36.8, 32.2, 24.6, 24.5; HRMS (APCI+) m/z: [M+H $]^{+}$Calcd for $\mathrm{C}_{18} \mathrm{H}_{25} \mathrm{O}_{4} \mathrm{BCl} 351.1529$; Found 351.1534.
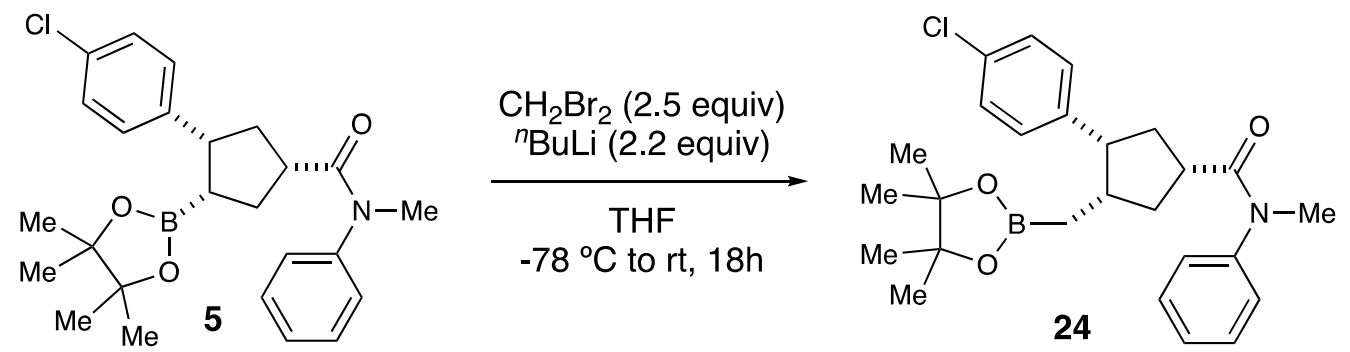

3-(4-chlorophenyl)- $N$-methyl- $N$-phenyl-4-((4,4,5,5-tetramethyl-1,3,2-dioxaborolan-2yl)methyl)cyclopentane-1-carboxamide (24): To an oven-dried 13 x $100 \mathrm{~mm}$ screw-cap vial was added boronic ester 5 ( $88 \mathrm{mg}, 0.20 \mathrm{mmol}, 1.0$ equiv.). The vial was evacuated/backfilled with $\mathrm{N}_{2}$ (3x) and sealed with a septum. THF $(2 \mathrm{~mL})$ and $\mathrm{CH}_{2} \mathrm{Br}_{2}(35 \mu \mathrm{L}, 0.50 \mathrm{mmol}, 2.5$ equiv. $)$ were then added via syringe. The solution was cooled to $-78^{\circ} \mathrm{C}$ before the addition of ${ }^{n} \mathrm{BuLi}$ in hexane (1.91 M, $0.23 \mathrm{~mL}, 0.44 \mathrm{mmol}, 2.2$ equiv.) dropwise over $10 \mathrm{~min}$. The reaction was stirred for $5 \mathrm{~min}$. at $-78{ }^{\circ} \mathrm{C}$ before warming to room temperature. The reaction was allowed to stir for $18 \mathrm{~h}$ at room temperature before being quenched upon the addition of $\mathrm{H}_{2} \mathrm{O}(3 \mathrm{~mL})$. The aqueous layer was then extracted with EtOAc ( $3 \times 2 \mathrm{~mL}$ ), and the combined organic layers were dried over $\mathrm{MgSO}_{4}$, filtered, and concentrated under reduced pressure. The crude mixture was purified via silica gel chromatography (6:1 hexanes: acetone) to yield 24 as a white solid (63 $\mathrm{mg}, 69 \%)$.

IR (neat): 2974 (s), 2925 (s), 1650 (s), 1371 (s), 1143 (s), 700 (s) cm ${ }^{-1}$; ${ }^{\mathbf{1}}$ H NMR (500 MHz, CDCl$\left._{3}\right): \delta 7.45-7.39(\mathrm{~m}, 2 \mathrm{H}), 7.35(\mathrm{t}, J=7.3 \mathrm{~Hz}, 1 \mathrm{H}), 7.25-7.16(\mathrm{~m}, 6 \mathrm{H}), 3.29(\mathrm{~s}, 3 \mathrm{H}), 3.05(\mathrm{q}$, $J=8.0 \mathrm{~Hz}, 1 \mathrm{H}), 2.72(\mathrm{p}, J=9.1 \mathrm{~Hz}, 1 \mathrm{H}), 2.20(\mathrm{tdd}, J=12.8,10.8,9.3,4.8 \mathrm{~Hz}, 2 \mathrm{H}), 2.05(\mathrm{dt}, J=$ $13.2,8.2 \mathrm{~Hz}, 1 \mathrm{H}), 1.88-1.71(\mathrm{~m}, 2 \mathrm{H}), 1.16(\mathrm{~d}, J=11.5 \mathrm{~Hz}, 12 \mathrm{H}), 0.45-0.16(\mathrm{~m}, 2 \mathrm{H}) ;{ }^{13} \mathbf{C}$ NMR (126 MHz, CDCl $): \delta 175.7,144.3,142.4,131.5,130.4,129.7,127.9,127.8,127.5,82.8,48.1$, 41.6, 40.1, 38.4, 37.7, 36.6, 25.0, 24.6; HRMS (APCI+) m/z: $[\mathrm{M}+\mathrm{H}]^{+}$Calcd for $\mathrm{C}_{26} \mathrm{H}_{34} \mathrm{O}_{3} \mathrm{NBCl}$ 454.2315; Found 454.2322.
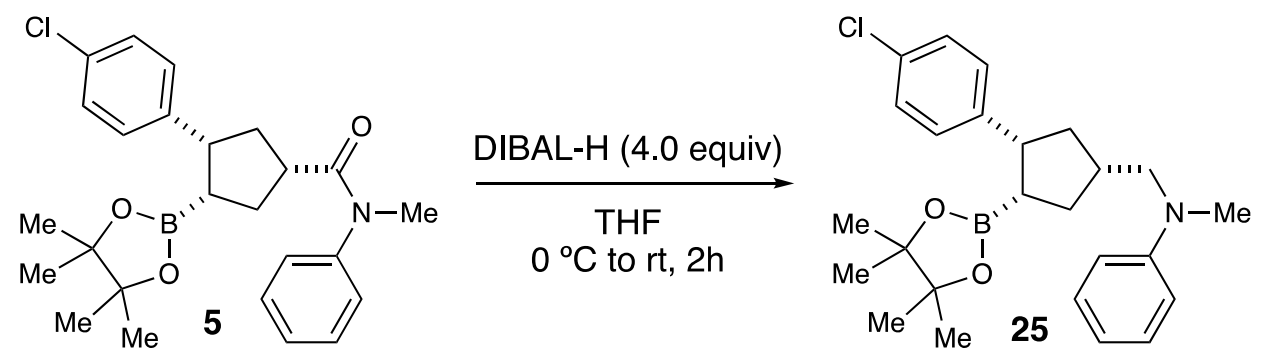

$N$-((3-(4-chlorophenyl)-4-(4,4,5,5-tetramethyl-1,3,2-dioxaborolan-2-yl)cyclopentyl)methyl)$\mathrm{N}$-methylaniline (25): To an oven-dried $25 \mathrm{~mL}$ round bottom flask was added boronic ester 5 (220 mg, $0.50 \mathrm{mmol}, 1.0$ equiv.). The flask was evacuated/backfilled with $\mathrm{N}_{2}(3 \mathrm{x})$ and sealed with a septum. THF $(5 \mathrm{~mL})$ was added and the resulting solution was cooled to $0{ }^{\circ} \mathrm{C}$ in an ice bath. 
DIBAL-H (2.0 mL, 1.0 M in hexanes, 4.0 equiv.) was added dropwise over $5 \mathrm{~min}$. The resulting solution was stirred at $0{ }^{\circ} \mathrm{C}$ for 2 hours. The reaction was quenched upon adding Rochelle's salt solution (sat. solution in $\mathrm{H}_{2} \mathrm{O}, 10 \mathrm{~mL}$ ). The resulting mixture was stirred at room temperature for 1 hour and $\mathrm{NaOH}$ ( $5 \mathrm{~mL}, 2 \mathrm{M}$ aqueous solution) was added. The aqueous layer was extracted with $\mathrm{Et}_{2} \mathrm{O}(3 \times 15 \mathrm{~mL})$, and the combined organic layers were dried over $\mathrm{MgSO}_{4}$, filtered, and concentrated under reduced pressure. The crude mixture was purified via silica gel column chromatography (20:1 hexanes: EtOAc) to yield 25 as a white solid (134 mg, 63\%).

IR (neat): 2974 (s), 2976 (s), 2862 (s), 1598 (s), 1378 (s), 1141 (s), 746 (s) cm ${ }^{-1}$; ${ }^{\mathbf{1}} \mathbf{H}$ NMR (500 MHz, CDCl3): $\delta 7.28-7.19(\mathrm{~m}, 6 \mathrm{H}), 6.77(\mathrm{~d}, J=8.2 \mathrm{~Hz}, 2 \mathrm{H}), 6.71(\mathrm{t}, J=7.3 \mathrm{~Hz}, 1 \mathrm{H}), 3.46(\mathrm{~d}, J$ $=7.0 \mathrm{~Hz}, 2 \mathrm{H}), 3.37(\mathrm{td}, J=10.3,7.2 \mathrm{~Hz}, 1 \mathrm{H}), 3.02(\mathrm{~s}, 3 \mathrm{H}), 2.55-2.42(\mathrm{~m}, 1 \mathrm{H}), 2.25(\mathrm{dt}, J=13.3$, $6.9 \mathrm{~Hz}, 1 \mathrm{H}), 2.06(\mathrm{dt}, J=12.6,7.9 \mathrm{~Hz}, 1 \mathrm{H}), 1.90(\mathrm{dt}, J=10.3,8.5 \mathrm{~Hz}, 1 \mathrm{H}), 1.71-1.53(\mathrm{~m}, 2 \mathrm{H})$, 1.02 (s, 6H), 0.95 (s, 6H); ${ }^{13}$ C NMR (126 MHz, CDCl3): $\delta$ 149.5, 144.5, 131.4, 129.4, 129.1, 128.0, 115.8, 112.0, 82.9, 57.6, 46.0, 40.0, 39.0, 38.9, 33.5, 24.8, 24.5; HRMS (ESI+) m/z: $[\mathrm{M}+\mathrm{H}]^{+}$Calcd for $\mathrm{C}_{25} \mathrm{H}_{34} \mathrm{O}_{2} \mathrm{NBCl} 426.2366$; Found 426.2365.
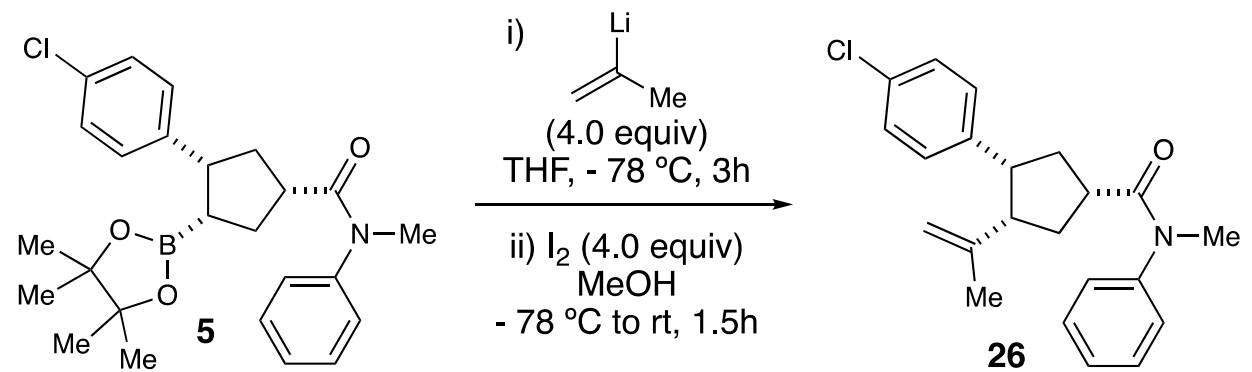

3-(4-chlorophenyl)- $N$-methyl- $N$-phenyl-4-(prop-1-en-2-yl)cyclopentane-1-carboxamide

(26): A flame-dried $25 \mathrm{~mL}$ round bottom flask under $\mathrm{N}_{2}$ was charged with 2-bromoprop-1-ene (71 $\mu \mathrm{L}, 0.80 \mathrm{mmol}, 4.0$ equiv.). THF $(4.0 \mathrm{~mL})$ was added and the solution cooled to $-78{ }^{\circ} \mathrm{C}$ in a dry ice/acetone bath. ${ }^{t} \mathrm{BuLi}(0.60 \mathrm{~mL}, 2.6 \mathrm{M}$ in pentane, $1.6 \mathrm{mmol}, 8.0$ equiv. $)$ was added dropwise and the solution stirred at $-78{ }^{\circ} \mathrm{C}$ for 1 hour. A solution of 5 (88 mg, $0.20 \mathrm{mmol}, 1.0$ equiv.) in THF $(0.8 \mathrm{~mL})$ was added dropwise at $-78{ }^{\circ} \mathrm{C}$ and the mixture was allowed to stir at $-78{ }^{\circ} \mathrm{C}$ for $3 \mathrm{~h}$. A solution of $\mathrm{I}_{2}(200 \mathrm{mg}, 0.80 \mathrm{mmol}, 4.0$ equiv.) in $\mathrm{MeOH}(0.8 \mathrm{~mL})$ was added dropwise down the side of the flask and the reaction was stirred at $-78^{\circ} \mathrm{C}$ for 30 minutes then allowed to warm to room temperature and stirred for $1 \mathrm{~h}$. The reaction was quenched upon the addition of $\mathrm{Na}_{2} \mathrm{~S}_{2} \mathrm{O}_{3}$ (sat. solution in $\mathrm{H}_{2} \mathrm{O}, 10.0 \mathrm{~mL}$ ) and stirred for another $1 \mathrm{~h}$. The organic layer was separated and the aqueous phase extracted with EtOAc $(3 \times 10 \mathrm{~mL})$. The combined organic layers were washed with brine $\left(1 \times 10 \mathrm{~mL}\right.$ ), dried over $\mathrm{MgSO}_{4}$, gravity filtered, and concentrated under reduced pressure. Crude material was purified by silica gel column chromatography (12:1 hexanes: acetone) to yield 26 as a colorless oil (53 $\mathrm{mg}$, 75\% yield).

IR (neat): 2939 (s), 1650 (s), 1493 (s), 1120 (s), 700 (s) cm ${ }^{-1} ;{ }^{1}$ H NMR (500 MHz, CDCl3): $\delta$ $7.45(\mathrm{t}, J=7.6 \mathrm{~Hz}, 2 \mathrm{H}), 7.38(\mathrm{t}, J=7.4 \mathrm{~Hz}, 1 \mathrm{H}), 7.26-7.17(\mathrm{~m}, 6 \mathrm{H}), 4.67(\mathrm{~s}, 1 \mathrm{H}), 4.59(\mathrm{~s}, 1 \mathrm{H})$, $3.32(\mathrm{~s}, 3 \mathrm{H}), 3.21(\mathrm{q}, J=8.1 \mathrm{~Hz}, 1 \mathrm{H}), 2.82-2.71(\mathrm{~m}, 1 \mathrm{H}), 2.65(\mathrm{td}, J=10.3,6.7 \mathrm{~Hz}, 1 \mathrm{H}), 2.35-$ $2.12(\mathrm{~m}, 3 \mathrm{H}), 1.81(\mathrm{dt}, J=13.2,6.8 \mathrm{~Hz}, 1 \mathrm{H}), 1.29(\mathrm{~s}, 3 \mathrm{H}) ;{ }^{13} \mathbf{C}$ NMR (126 MHz, CDCl 3$): \delta 175.4$, 145.1, 144.1, 142.3, 131.5, 130.1, 129.8, 127.9, 127.8, 127.4, 111.8, 51.6, 47.0, 41.3, 37.7, 37.6, 34.9, 22.6; HRMS (ESI+) m/z: [M+H] ${ }^{+}$Calcd for $\mathrm{C}_{22} \mathrm{H}_{25} \mathrm{ONCl} 354.1619$; Found 354.1620.

\section{- Gram Scale Reaction Procedure}




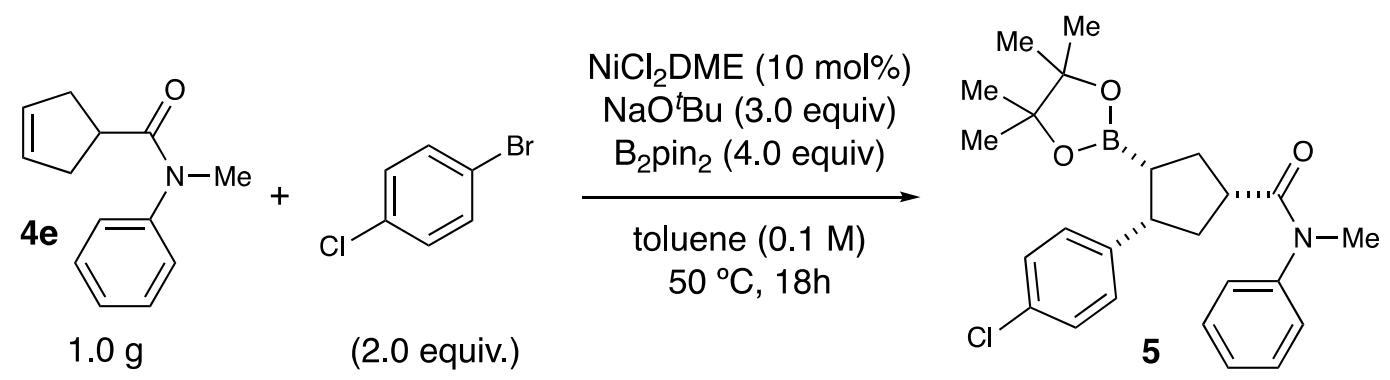

In an $\mathrm{N}_{2}$-filled glovebox, to a flame-dried 100-mL round-bottomed flask equipped with a stir bar was added $\mathrm{Ni}(\mathrm{DME}) \mathrm{Cl}_{2}$ (110 mg, $0.50 \mathrm{mmol}, 0.10$ equiv.), bis(pinacolato)diboron (5.08 $\mathrm{g}, 20.0$ mmol, 4.00 equiv.), 1-bromo-4-chlorobenzene (1.92 g, $10.0 \mathrm{mmol}, 2.00$ equiv.), and $\mathrm{NaO} t-\mathrm{Bu}$ (1.44 g, $15.0 \mathrm{mmol}, 3.00$ equiv.). The flask was sealed with a septum and removed from the glovebox. Toluene $(50 \mathrm{~mL})$ was added to the reaction vial immediately followed by $N$-methyl- $N$ phenylcyclopent-3-ene-1-carboxamide $(4 \mathbf{e})(0.95 \mathrm{~mL}, 1.0 \mathrm{~g}, 5.0 \mathrm{mmol}, 1.0$ equiv.). The reaction was stirred at $50{ }^{\circ} \mathrm{C}$ for $18 \mathrm{~h}$ in an oil bath, then quenched upon the addition of $1 \mathrm{M} \mathrm{HCl}(50 \mathrm{~mL})$, and the mixture was extracted with EtOAc $(3 \times 30 \mathrm{~mL})$, washed with $1 \mathrm{M} \mathrm{KOH}(3 \times 50 \mathrm{~mL})$, dried over $\mathrm{MgSO}_{4}$, gravity filtered, and concentrated. 1,3,5-Trimethylbenzene was added as an internal standard and a small aliquot was analyzed via ${ }^{1} \mathrm{H}$ NMR. Purification by silica gel column chromatography (Gradient: toluene to 20:1 toluene: acetone) yielded product 5 as a white solid $(1.6 \mathrm{~g}, 71 \%)$.

\section{Mechanism Studies:}

\section{Counterion Studies (Scheme 6A):}

In an $\mathrm{N}_{2}$-filled glovebox, to an oven-dried $16 \times 100 \mathrm{~mm}$ screw-capped vial was added $\mathrm{Ni}(\mathrm{DME}) \mathrm{Cl}_{2}$ (11 mg, $0.050 \mathrm{mmol}, 0.10$ equiv.), bis(pinacolato)diboron (508 mg, $2.00 \mathrm{mmol}, 4.00$ equiv.), 1 bromo-4-chlorobenzene (192 mg, $1.00 \mathrm{mmol}, 2.00$ equiv.), and base (1.50 mmol, 3.00 equiv.). The vial was sealed with a septum and removed from the glovebox. The toluene $(5.0 \mathrm{~mL}, 0.1 \mathrm{M})$ was added to the reaction vial, followed by alkene $4 \mathbf{e}(95 \mu \mathrm{L}, 0.50 \mathrm{mmol}, 1.0$ equiv.). The septum was then quickly replaced by a Teflon-lined screw cap and the reaction was stirred at $50{ }^{\circ} \mathrm{C}$ for $18 \mathrm{~h}$ in a temperature-controlled aluminum block. The reaction was quenched upon the addition of $1 \mathrm{M}$ $\mathrm{HCl}(5 \mathrm{~mL})$, and the mixture was extracted with EtOAc $(3 \times 3 \mathrm{~mL})$, washed with $1 \mathrm{M} \mathrm{KOH}(3 \times 5$ $\mathrm{mL})$, dried over $\mathrm{MgSO}_{4}$, gravity filtered, and concentrated. 1,3,5-Trimethylbenzene (28 $\mu \mathrm{L}, 0.2$ mmol) was added as an internal standard and a small aliquot was analyzed via ${ }^{1} \mathrm{H}$ NMR.

Table S1: Counterion effect on diastereoselectivity

\begin{tabular}{|c|c|c|c|c|}
\hline Entry & Base & \% syn (5) & \% anti (27) & dr (syn:anti) \\
\hline $\mathbf{1}$ & $\mathrm{KO}^{t} \mathrm{Bu}$ & 80 & 3 & $23: 1$ \\
\hline $\mathbf{2}$ & $\mathrm{NaO}^{t} \mathrm{Bu}$ & 79 & 6 & $12: 1$ \\
\hline $\mathbf{3}$ & $\mathrm{LiO}^{t} \mathrm{Bu}$ & 39 & 6 & $7: 1$ \\
\hline
\end{tabular}

\section{Counterion Studies with Corresponding Crown Ether (Scheme 6A):}

In an $\mathrm{N}_{2}$-filled glovebox, to an oven-dried 16 x $100 \mathrm{~mm}$ screw-capped vial was added $\mathrm{Ni}(\mathrm{DME}) \mathrm{Cl}_{2}$ (11 mg, $0.050 \mathrm{mmol}, 0.10$ equiv.), bis(pinacolato)diboron (508 mg, $2.00 \mathrm{mmol}, 4.00$ equiv.), 1 bromo-4-chlorobenzene (192 mg, $1.00 \mathrm{mmol}, 2.00$ equiv.), base (1.50 mmol, 3.00 equiv.), and 18crown-6 (396 mg, $1.50 \mathrm{mmol}, 3.0$ equiv.) when applicable. The vial was sealed with a septum and removed from the glovebox. The toluene $(5.0 \mathrm{~mL}, 0.1 \mathrm{M})$ was added to the reaction vial, followed 
by alkene $4 \mathrm{e}(95 \mu \mathrm{L}, 0.50 \mathrm{mmol}, 1.0$ equiv.) and 15-crown-5 (297 $\mu \mathrm{L}, 1.50 \mathrm{mmol}, 3.00$ equiv.) or 12-crown-4 (243 $\mu \mathrm{L}, 1.50 \mathrm{mmol}, 3.00$ equiv.) when applicable. The septum was then quickly replaced by a Teflon-lined screw cap and the reaction was stirred at $50{ }^{\circ} \mathrm{C}$ for $18 \mathrm{~h}$ in a temperaturecontrolled aluminum block. The reaction was quenched upon the addition of $1 \mathrm{M} \mathrm{HCl}(5 \mathrm{~mL})$, and the mixture was extracted with EtOAc $(3 \times 3 \mathrm{~mL})$, washed with $1 \mathrm{M} \mathrm{KOH}(3 \times 5 \mathrm{~mL})$, dried over $\mathrm{MgSO}_{4}$, gravity filtered, and concentrated. 1,3,5-Trimethylbenzene (28 $\left.\mu \mathrm{L}, 0.2 \mathrm{mmol}\right)$ was added as an internal standard and a small aliquot was analyzed via ${ }^{1} \mathrm{H}$ NMR.

Table S2: Crown Ether effect on diastereoselectivity

\begin{tabular}{|c|c|c|c|c|c|}
\hline Entry & Base & Crown Ether & \% syn (5) & \% anti (27) & dr (syn:anti) \\
\hline $\mathbf{1}$ & $\mathrm{KO}^{t} \mathrm{Bu}$ & 18 -crown-6 & 25 & $<1$ & $>30: 1$ \\
\hline $\mathbf{2}$ & $\mathrm{NaO}^{t} \mathrm{Bu}$ & 15 -crown-5 & 81 & $<1$ & $>30: 1$ \\
\hline $\mathbf{3}$ & $\mathrm{LiO}^{t} \mathrm{Bu}$ & 12 -crown-4 & 86 & $<1$ & $>30: 1$ \\
\hline
\end{tabular}

\section{Solvent Ratios Studies (Scheme 6B):}

In an $\mathrm{N}_{2}$-filled glovebox, to an oven-dried 16 x $100 \mathrm{~mm}$ screw-capped vial was added $\mathrm{Ni}(\mathrm{DME}) \mathrm{Cl}_{2}$ (11 mg, $0.050 \mathrm{mmol}, 0.10$ equiv.), bis(pinacolato)diboron (508 mg, $2.00 \mathrm{mmol}, 4.00$ equiv.), 1 bromo-4-chlorobenzene (192 mg, $1.00 \mathrm{mmol}, 2.00$ equiv.), and $\mathrm{KO} t$-Bu (168 mg, $1.50 \mathrm{mmol}, 3.00$ equiv.). The vial was sealed with a septum and removed from the glovebox. The toluene:DMA solvent $(5.0 \mathrm{~mL}, 0.1 \mathrm{M})$ was added to the reaction vial, followed by alkene $4 \mathbf{e}(95 \mu \mathrm{L}, 0.50 \mathrm{mmol}$, 1.0 equiv.). The septum was then quickly replaced by a Teflon-lined screw cap and the reaction was stirred at $50{ }^{\circ} \mathrm{C}$ for $18 \mathrm{~h}$ in a temperature-controlled aluminum block. The reaction was quenched upon the addition of $1 \mathrm{M} \mathrm{HCl}(5 \mathrm{~mL})$, and the mixture was extracted with EtOAc $(3 \times 3$ $\mathrm{mL})$, washed with $1 \mathrm{M} \mathrm{KOH}(3 \times 5 \mathrm{~mL})$, dried over $\mathrm{MgSO}_{4}$, gravity filtered, and concentrated. 1,3,5-Trimethylbenzene $(28 \mu \mathrm{L}, 0.2 \mathrm{mmol})$ was added as an internal standard and a small aliquot was analyzed via ${ }^{1} \mathrm{H}$ NMR.

Table S3: Relating solvent ratio to diastereoselectivity

\begin{tabular}{|c|c|c|c|c|}
\hline Entry & toluene:DMA & \% syn (5) & \% anti (27) & dr (syn:anti) \\
\hline $\mathbf{1}$ & $1: 0$ & 75 & 3 & $23: 1$ \\
\hline $\mathbf{2}$ & $9: 1$ & 77 & 3 & $26: 1$ \\
\hline $\mathbf{3}$ & $4: 1$ & 78 & 5 & $16: 1$ \\
\hline $\mathbf{4}$ & $2: 1$ & 70 & 11 & $6.1: 1$ \\
\hline $\mathbf{5}$ & $1: 1$ & 54 & 24 & $2.2: 1$ \\
\hline $\mathbf{6}$ & $1: 2$ & 39 & 49 & $1: 1.3$ \\
\hline $\mathbf{7}$ & $1: 4$ & 35 & 56 & $1: 1.6$ \\
\hline $\mathbf{8}$ & $1: 9$ & 25 & 61 & $1: 2.4$ \\
\hline $\mathbf{9}$ & $0: 1$ & 23 & 66 & $1: 3.0$ \\
\hline
\end{tabular}




\section{口X-ray Crystal Structures:}

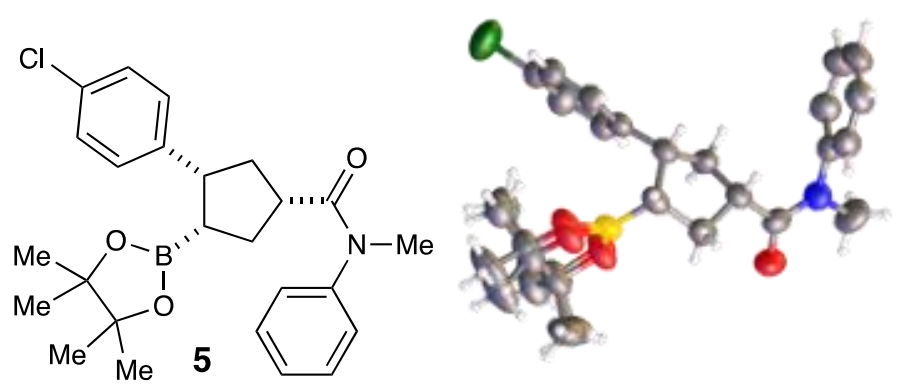

The ellipsoid contour percent probability level is $50 \%$ for the image of the structure.

Table S4. Crystal data and structure refinement for 5.

Empirical formula

Formula weight

Crystal color, shape, size

Temperature

Wavelength

Crystal system, space group

Unit cell dimensions

Volume

$\mathrm{Z}$

Density (calculated)

Absorption coefficient

$\mathrm{F}(000)$

\section{Data collection}

Diffractometer

Theta range for data collection

Index ranges

Reflections collected

Independent reflections

Observed Reflections

Completeness to theta $=25.242^{\circ}$

\section{Solution and Refinement}

Absorption correction

Max. and min. transmission

Solution

Refinement method
C25 H31 B Cl N O3

439.77

colourless plate, $0.25 \times 0.1 \times 0.02 \mathrm{~mm}^{3}$

$100.0 \mathrm{~K}$

$0.71073 \AA$

Monoclinic, P 1 21/c 1

$\mathrm{a}=7.2807(4) \AA$

$\mathrm{b}=37.463(3) \AA$

$\alpha=90^{\circ}$.

$\mathrm{c}=9.2992(6) \AA$

$\beta=112.541(2)^{\circ}$.

2342.7(3) $\AA^{3}$

4

$1.247 \mathrm{~g} / \mathrm{cm}^{3}$

$0.189 \mathrm{~mm}^{-1}$

936

Bruker Venture D8, Photon III

2.174 to $26.372^{\circ}$.

$-9<=\mathrm{h}<=9,-46<=\mathrm{k}<=46,-11<=\mathrm{l}<=11$

29834

4786 [Rint $=0.1008$ ]

2805

$99.8 \%$

Semi-empirical from equivalents

0.7454 and 0.5317

Intrinsic methods

Full-matrix least-squares on $\mathrm{F}^{2}$ 
Weighting scheme

Data / restraints / parameters

Goodness-of-fit on $\mathrm{F}^{2}$

Final $R$ indices $[\mathrm{I}>2 \sigma(\mathrm{I})]$

$\mathrm{R}$ indices (all data)

Extinction coefficient

Largest diff. peak and hole $\mathrm{w}=\left[\sigma^{2} \mathrm{Fo}^{2}+\mathrm{AP}^{2}+\mathrm{BP}\right]^{-1}$, with

$\mathrm{P}=\left(\mathrm{Fo}^{2}+2 \mathrm{Fc}^{2}\right) / 3, \mathrm{~A}=, \mathrm{B}=$

4786 / 359 / 308

1.088

$\mathrm{R} 1=0.0762, \mathrm{wR}_{2}=0.1916$

$\mathrm{R} 1=0.1182, \mathrm{wR} 2=0.2204$

$\mathrm{n} / \mathrm{a}$

0.273 and -0.412 e. $\AA^{-3}$

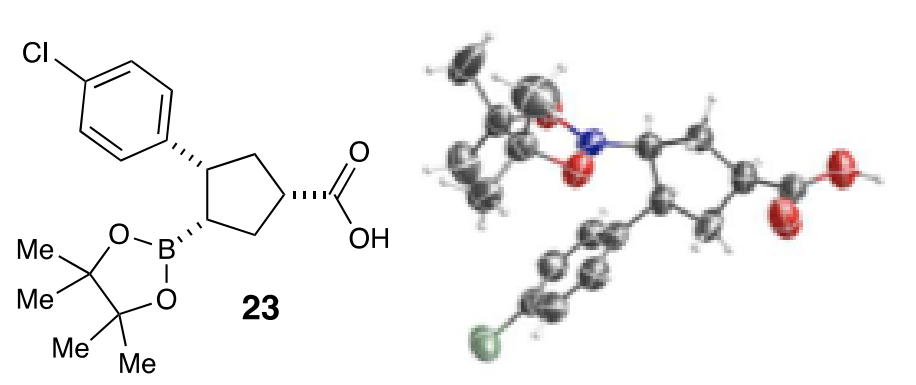

The ellipsoid contour percent probability level is $50 \%$ for the image of the structure.

Table S5. Crystal data and structure refinement for 23.

Empirical formula

Formula weight

Crystal color, shape, size

Temperature

Wavelength

Crystal system, space group

Unit cell dimensions

Volume

$\mathrm{Z}$

Density (calculated)

Absorption coefficient

$\mathrm{F}(000)$

\section{Data collection}

Diffractometer

Source

Detector
$\mathrm{C} 18 \mathrm{H} 24 \mathrm{~B} \mathrm{Cl} \mathrm{O} 4$

350.63

colorless needle, $0.21 \times 0.05 \times 0.05 \mathrm{~mm}^{3}$

253(2) K

$0.71073 \AA$

Triclinic, P-1

$\mathrm{a}=6.6223(5) \AA$

$\mathrm{b}=10.8658(10) \AA$

$\alpha=108.954(3)^{\circ}$.

$\mathrm{c}=13.8513(13) \AA$

$920.16(14) \AA^{3}$

2

$1.266 \mathrm{Mg} / \mathrm{m}^{3}$

$0.225 \mathrm{~mm}^{-1}$

372

Venture D8, Bruker

I $\mu$ S 3.0, Incoatec

Photon III 
Theta range for data collection

Index ranges

Reflections collected

Independent reflections

Observed Reflections

Completeness to theta $=25.242^{\circ}$

\section{Solution and Refinement}

Absorption correction

Max. and min. transmission

Solution

Refinement method

Weighting scheme

Data / restraints / parameters

Goodness-of-fit on $\mathrm{F}^{2}$

Final $R$ indices $[\mathrm{I}>2 \sigma(\mathrm{I})]$

$\mathrm{R}$ indices (all data)

Largest diff. peak and hole
1.991 to $25.715^{\circ}$.

$-8<=\mathrm{h}<=8,-13<=\mathrm{k}<=13,-16<=\mathrm{l}<=16$

44351

3479 [Rint $=0.1211]$

2180

$99.6 \%$

Semi-empirical from equivalents

0.7453 and 0.6822

Intrinsic methods

Full-matrix least-squares on $\mathrm{F}^{2}$

$\mathrm{w}=\left[\sigma^{2} \mathrm{Fo}^{2}+\mathrm{AP}^{2}+\mathrm{BP}\right]^{-1}$, with

$\mathrm{P}=\left(\mathrm{Fo}^{2}+2 \mathrm{Fc}^{2}\right) / 3, \mathrm{~A}=0.0783, \mathrm{~B}=0.7349$

3479 / 212 / 254

1.067

$\mathrm{R} 1=0.0627, \mathrm{wR} 2=0.1508$

$\mathrm{R} 1=0.1055, \mathrm{wR} 2=0.2058$

0.345 and -0.375 e. $\AA^{-3}$ 


\section{References:}

${ }^{1}$ Shin, K.; Joung, S.; Kim, Y.; Chang, S. Adv. Synth. Catal. 2017, 359, 3428-3436.

${ }^{2} \mathrm{Su}$, W.-G.; Deng, W. Substituted Pyridopyrazines as Syk Inhibitors. International Patent WO 2014/086316 A1, June 12, 2014.

${ }^{3}$ Matrinez, A. A.; Espinosa, B. A.; Adamek, R. N.; Thomas, B. A.; Chau, J.; Gonzalex, E.;

Keppetipola, N.; Salzamdeda, N. T. Eur. J. Med. Chem. 2018, 157, 1202-1213.

${ }^{4}$ Hoang, G. L.; Yang, Z.-D.; Smith, S. M.; Pal, R.; Miska, J. L.; Perez, D. E.; Pelter, L. S.; Zeng, X. C.; Takacs, J. M. Org. Lett. 2015, 17, 940-943.

${ }^{5}$ Chen, M.; Ren, Z.-H.; Wang, Y.-Y.; Guan, Z.-H. J. Org. Chem. 2015, 80, 1258-1263.

${ }^{6}$ Wu, H.; Wang, Q.; Zhu, J. Angew. Chem. Int. Ed. 2018, 57, 2721-2725.

${ }^{7}$ Li, L.; Wei, E.; Lin, S.; Liu, B.; Liang, F. SynLett 2014, 25, 2271-2274.

${ }^{8}$ Huang, S.; Bilel, H.; Zagrouba, F.; Hamdi, N.; Bruneau, C.; Fischmeister, C. Catal. Commun. 2015, 63, 31-34.

${ }^{9}$ Shin, K.; Joung, S.; Kim, Y.; Chang, S. Adv. Synth. Catal. 2017, 359, 3428-3436.

${ }^{10}$ Kirkland, T. A.; Grubbs, R. H. J. Org. Chem. 1997, 62, 7310-7318.

${ }^{11}$ Wu, J. W. T.; Thornton, E. R. J. Org. Chem. 1975, 40, 1041-1046.

\section{${ }^{1} \mathrm{H},{ }^{13} \mathrm{C}$, and ${ }^{19} \mathrm{~F}$ NMR Spectra:}


$\mathrm{CDCl} 3,400 \mathrm{MHz}$

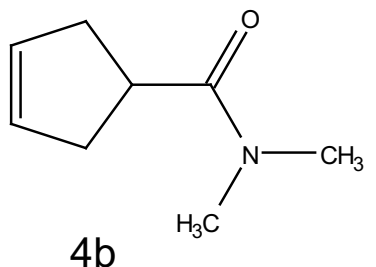

$4 b$

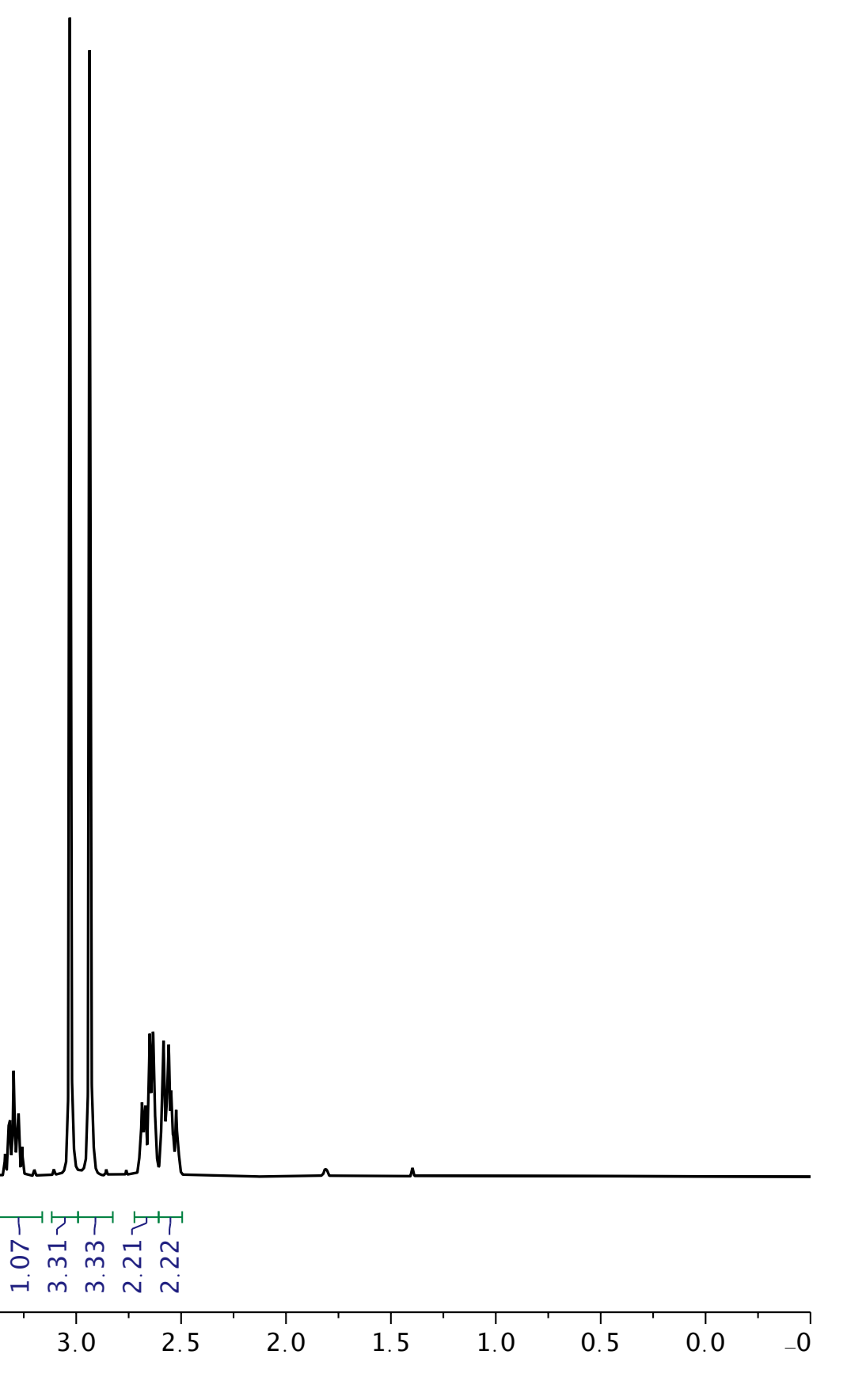




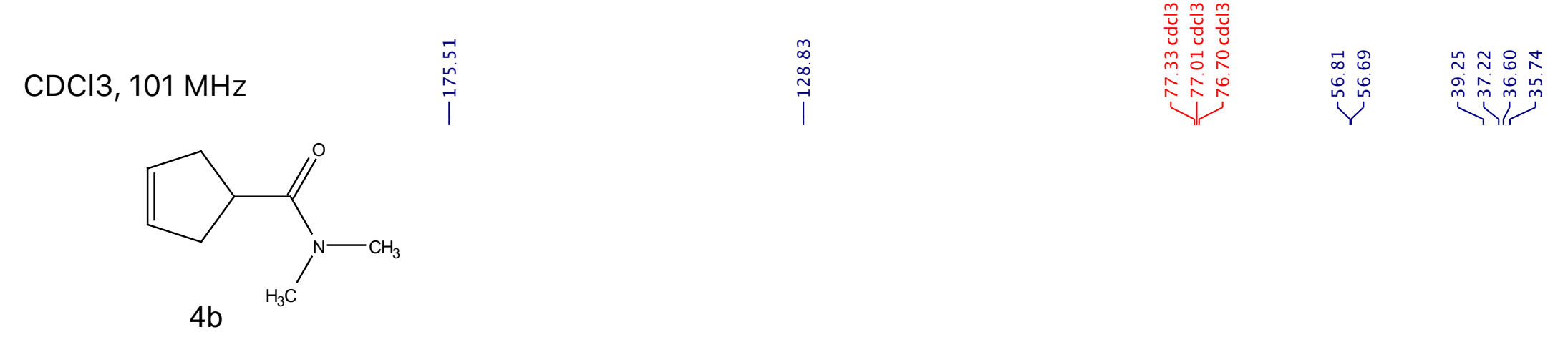




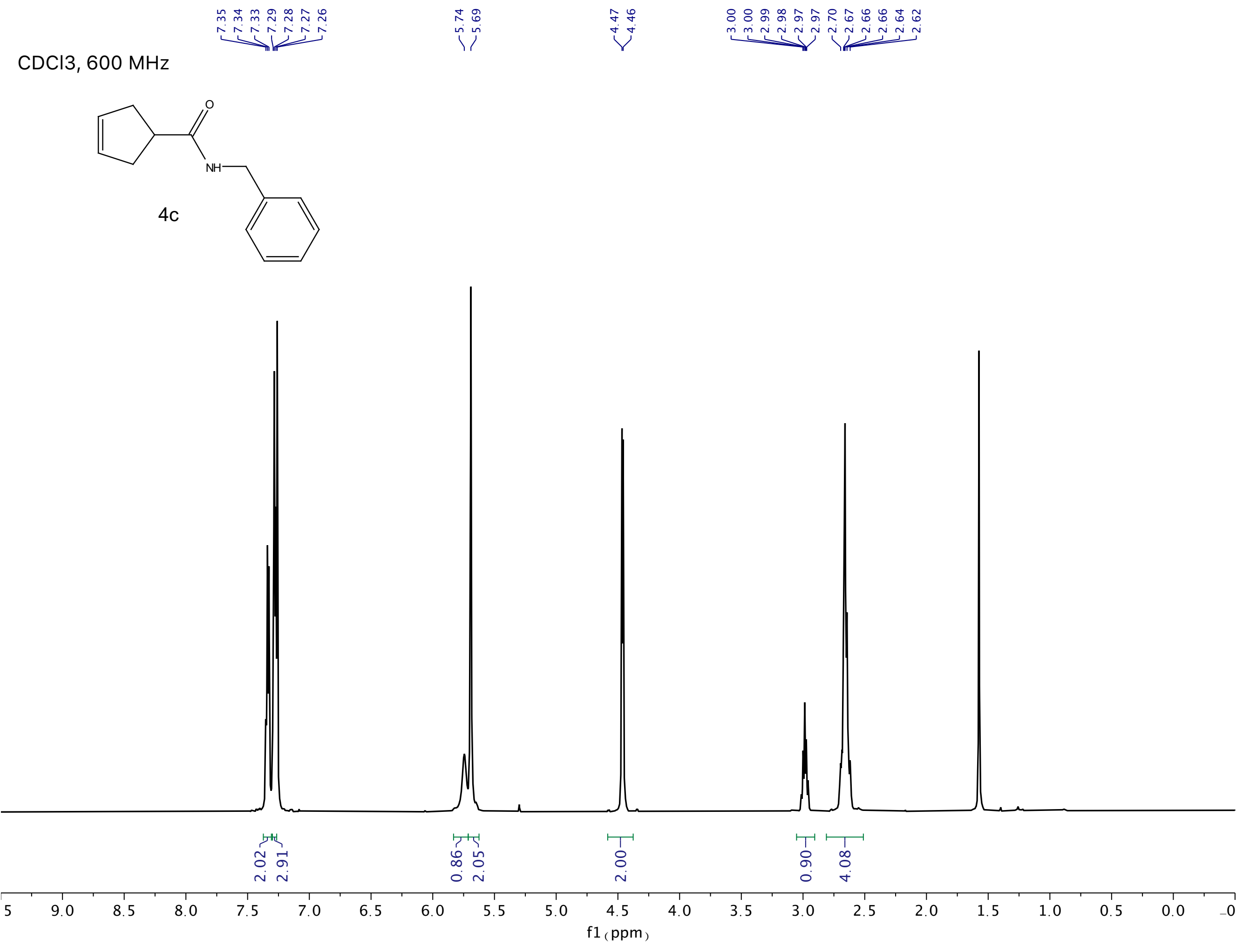




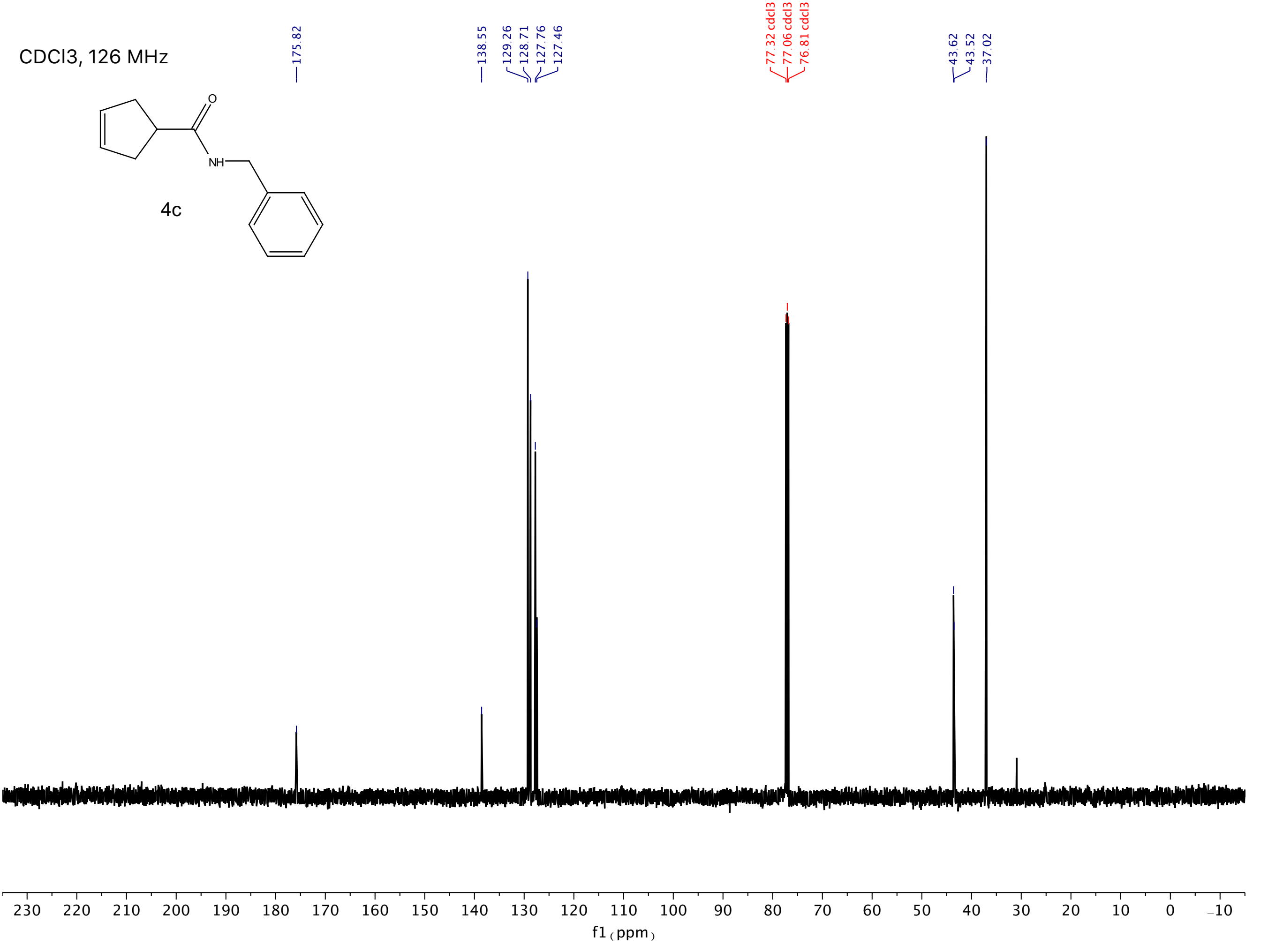


$\mathrm{CDCl} 3,600 \mathrm{MHz}$
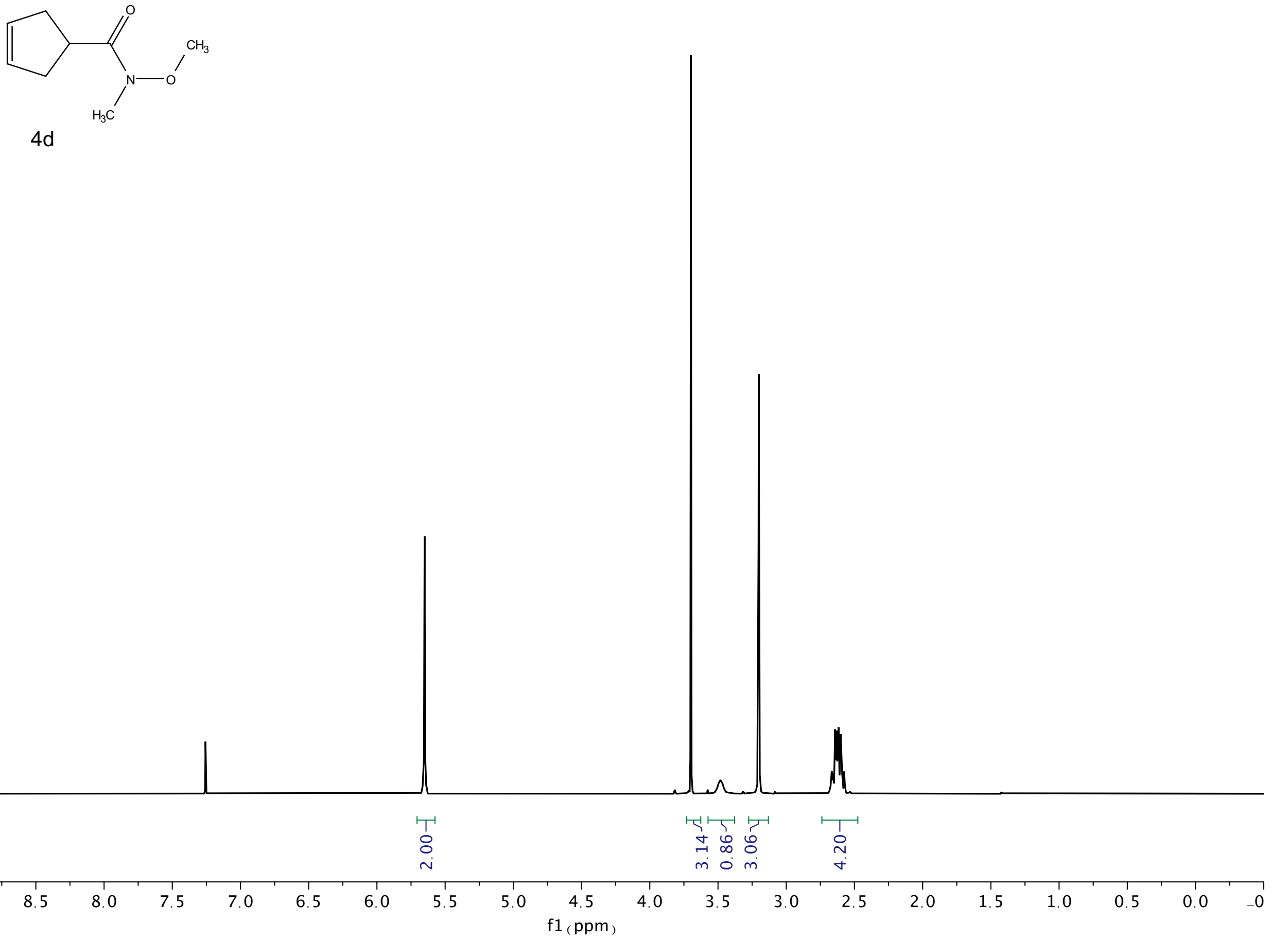
$\mathrm{CDCl} 3,600 \mathrm{MHz}$

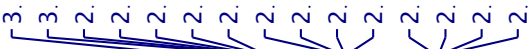
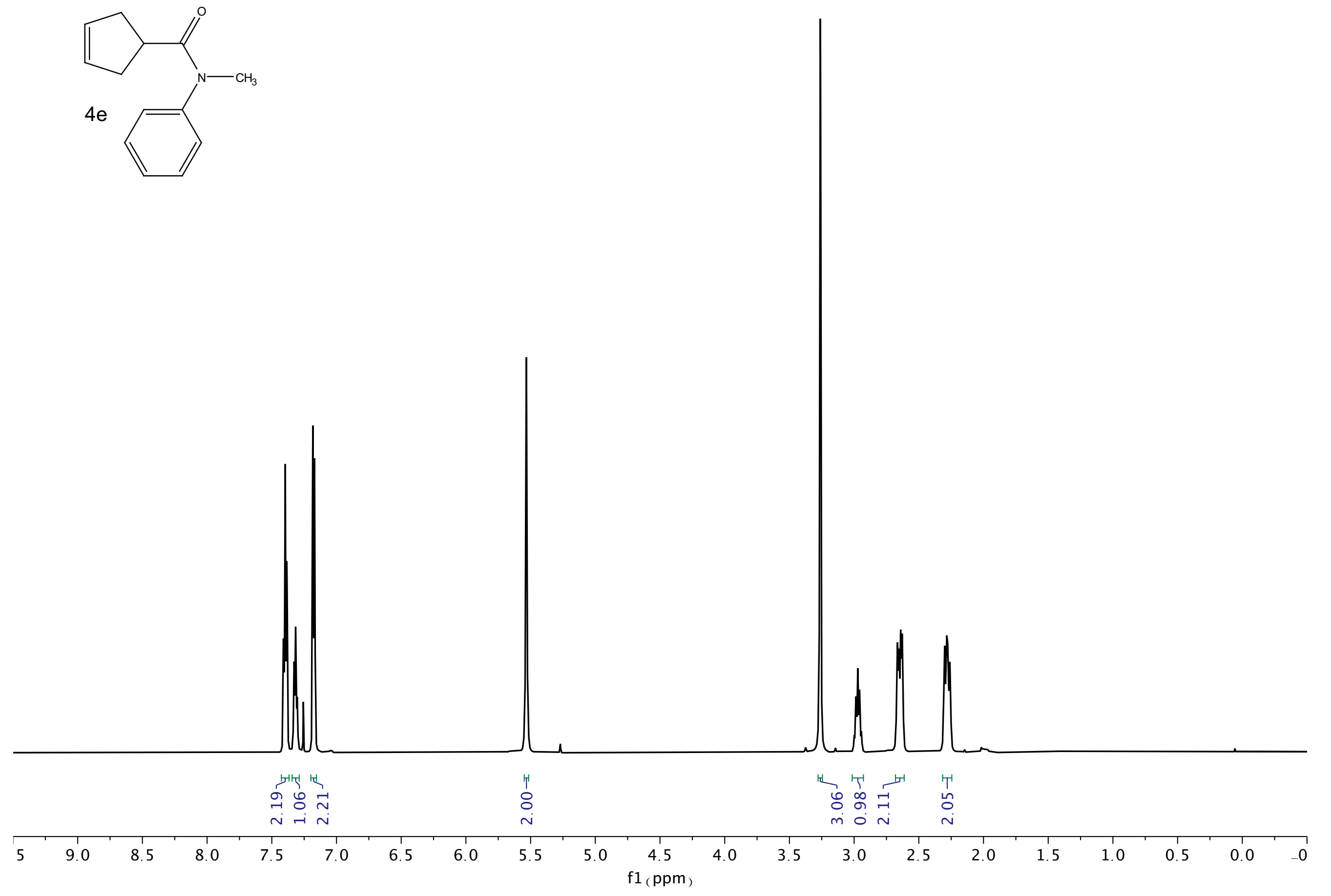


\section{$\mathrm{CDCl} 3,101 \mathrm{MHz}$}

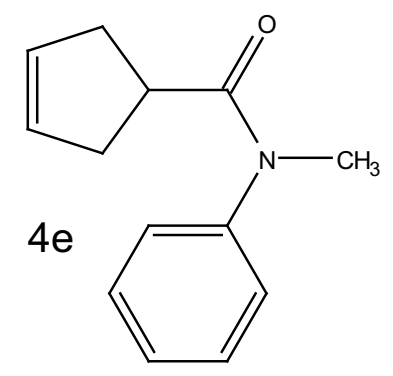

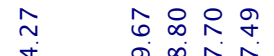

咅
ㅇํㅂำ

$\sum_{n}^{n} \hat{m} \stackrel{\hat{n}}{\hat{n}}$

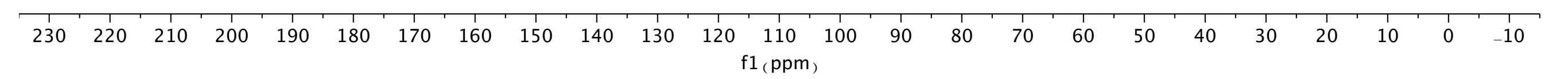


$\mathrm{CDCl}, 600 \mathrm{MHz}$

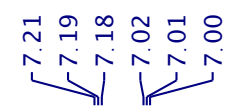

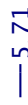

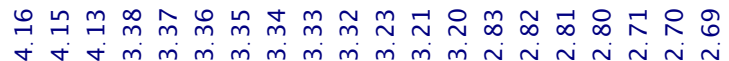
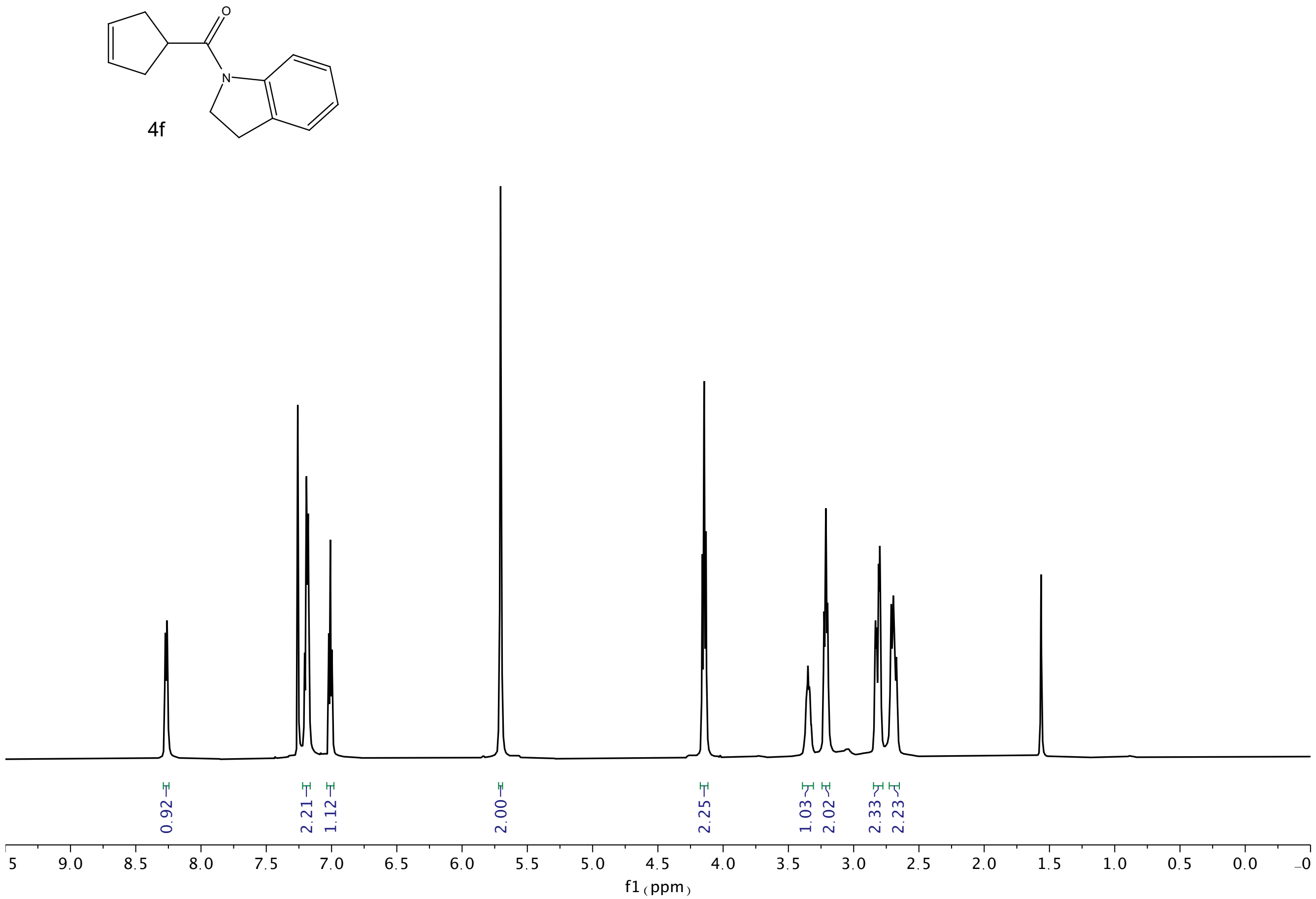


$\mathrm{CDCl}, 126 \mathrm{MHz}$
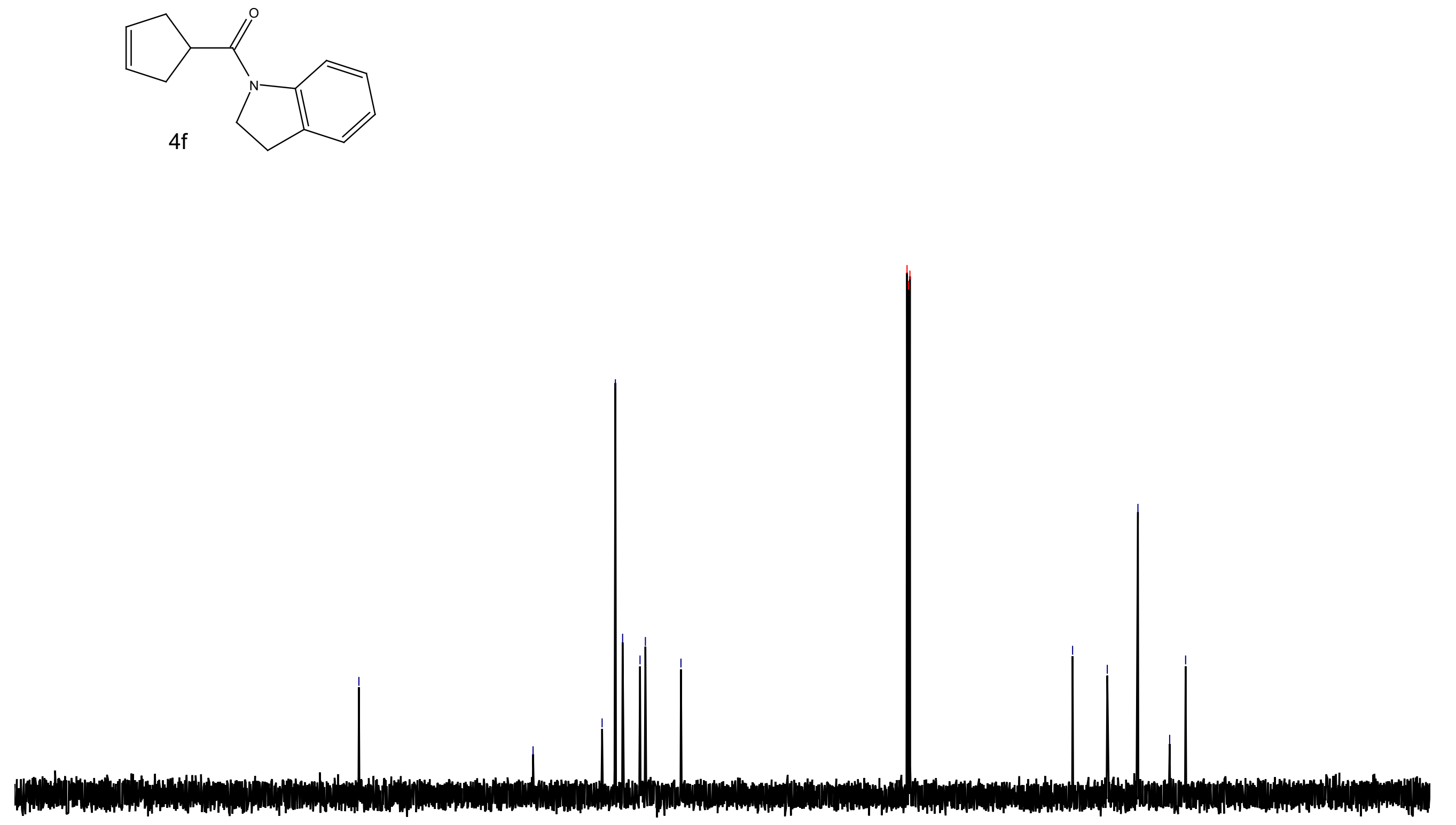

\begin{tabular}{llllllllllllllllllllllllllll}
\hline 230 & 220 & 210 & 200 & 190 & 180 & 170 & 160 & 150 & 140 & 130 & 120 & 110 & 100 & 90 & 80 & 70 & 60 & 50 & 40 & 30 & 20 & 10 & 0 & -10 \\
$\mathrm{f} 1(\mathrm{ppm})$
\end{tabular}


CDCl3, $500 \mathrm{MHz}$

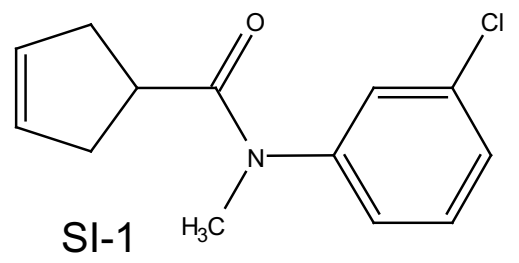

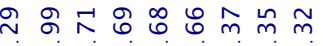

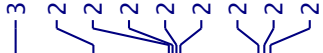

$\mathrm{SI}-1$

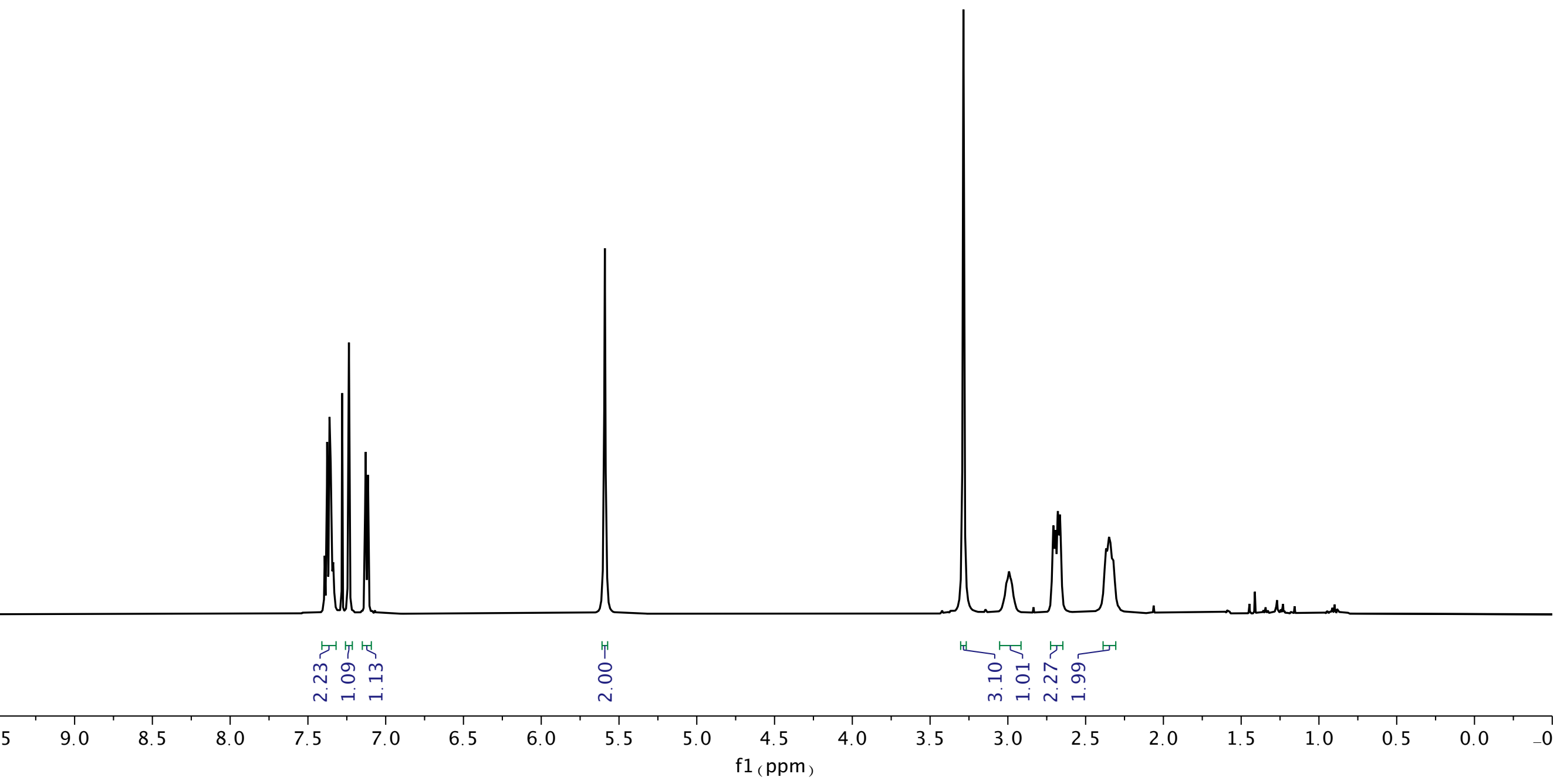



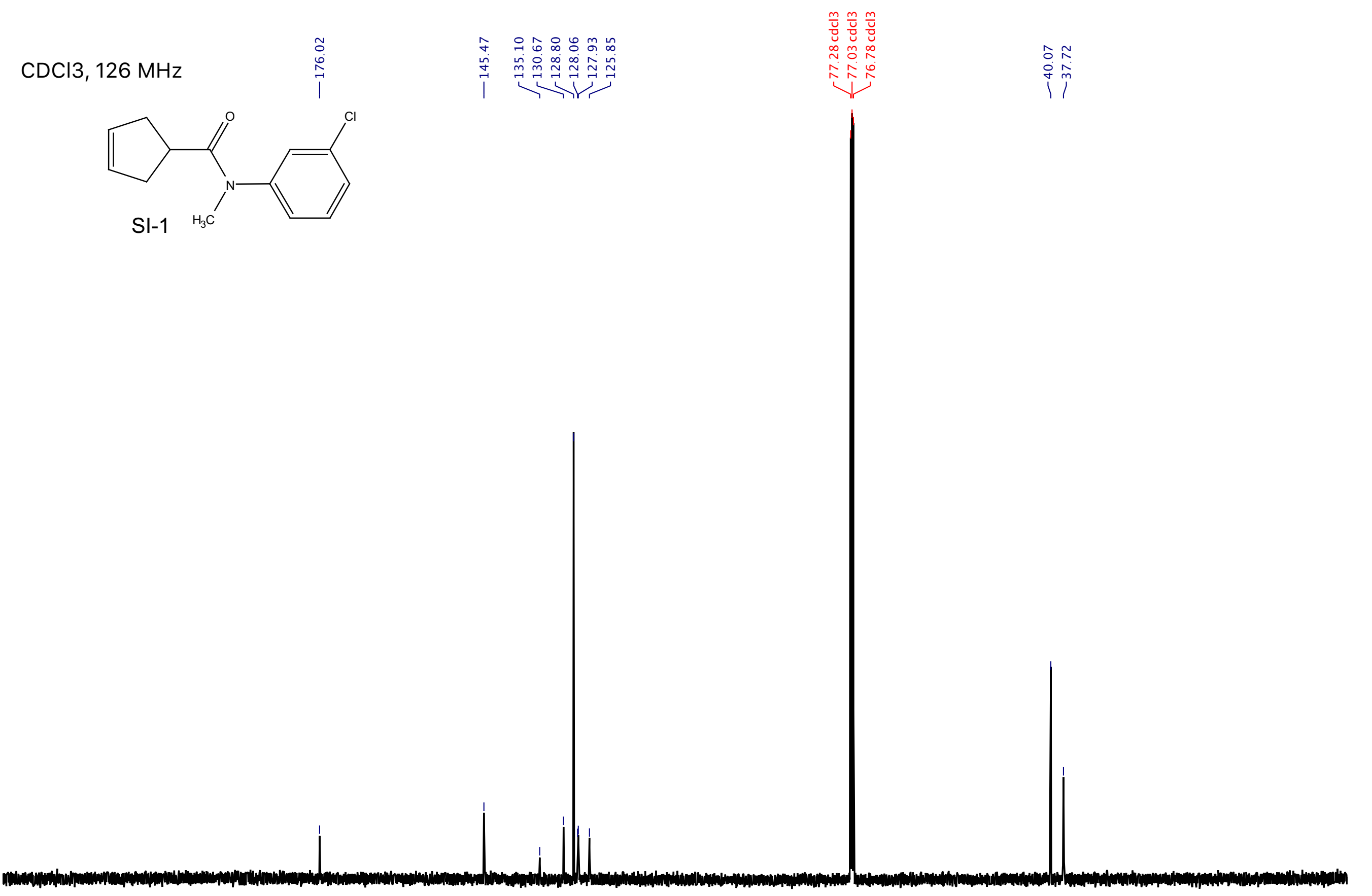

\begin{tabular}{|c|c|c|c|c|c|c|c|c|c|c|c|c|c|c|c|c|c|c|c|c|c|c|c|c|}
\hline 230 & 220 & 210 & 200 & 190 & 180 & 170 & 160 & 150 & 140 & 130 & 120 & $\begin{array}{r}110 \\
\mathrm{f} 1(\mathrm{ppn}\end{array}$ & 100 & 90 & 80 & 70 & 60 & 50 & 40 & 30 & 20 & 10 & 0 & -10 \\
\hline
\end{tabular}


$\mathrm{CDCl} 3,500 \mathrm{MHz}$
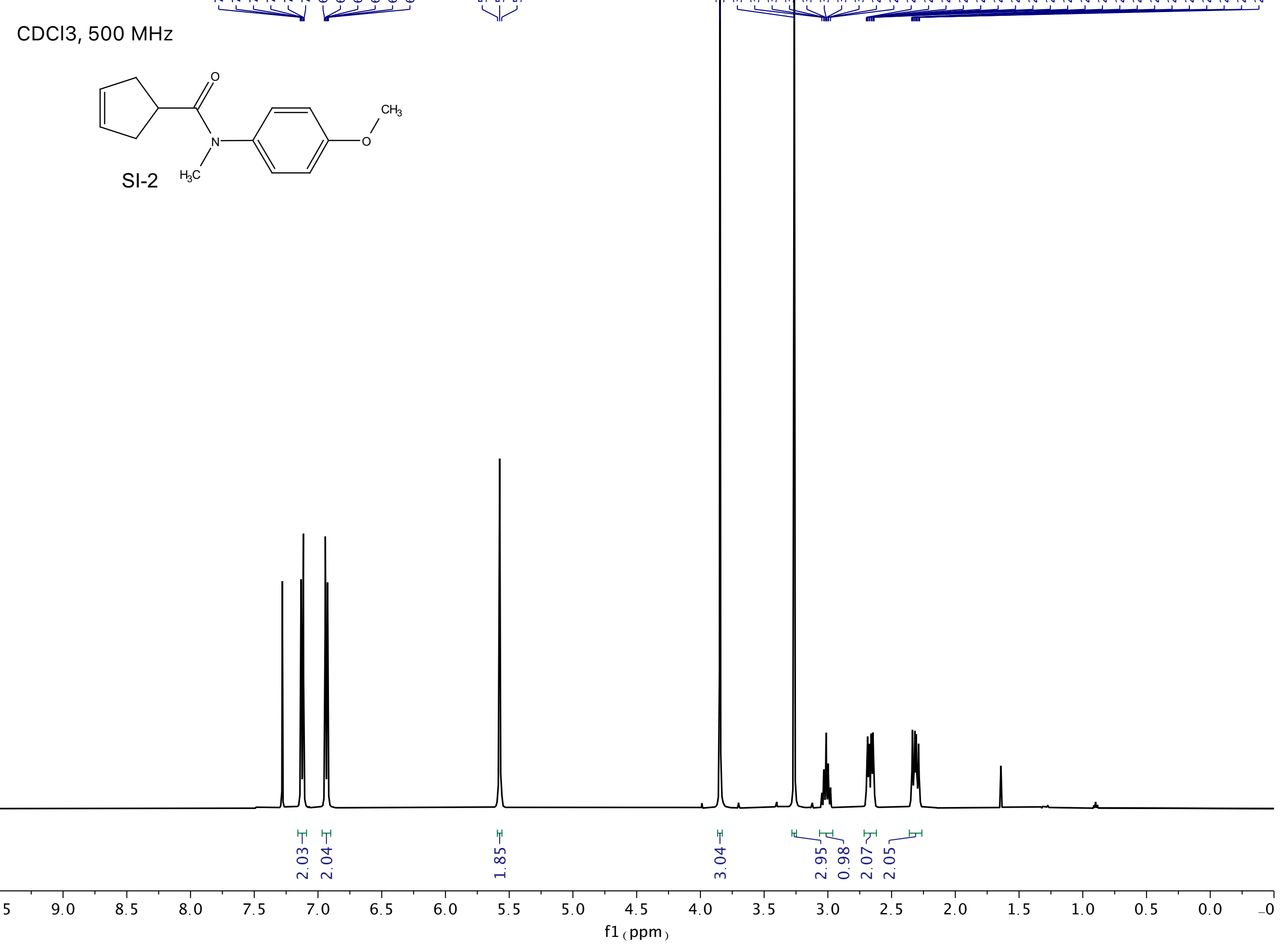


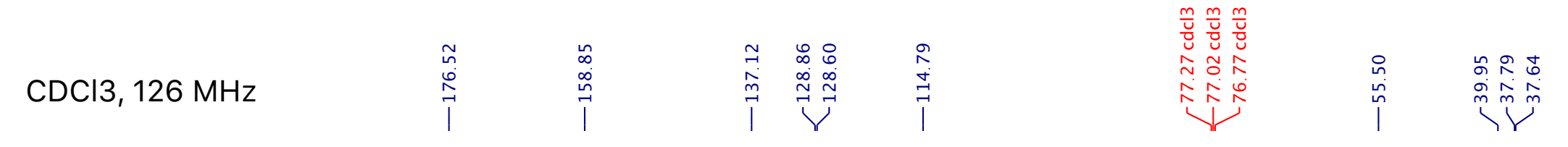
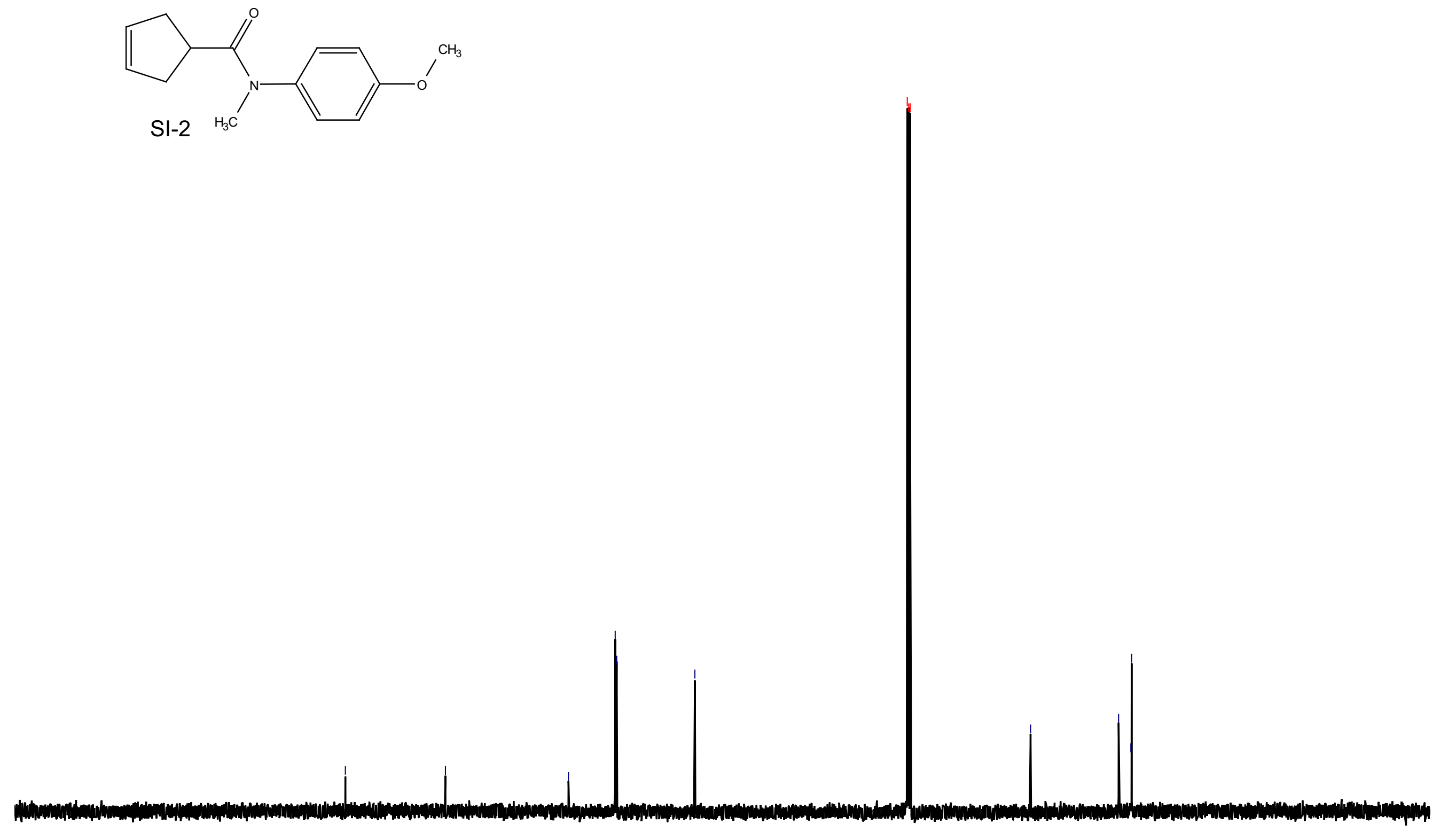

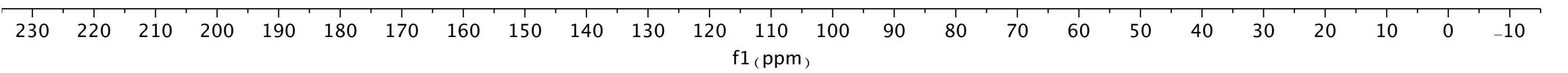




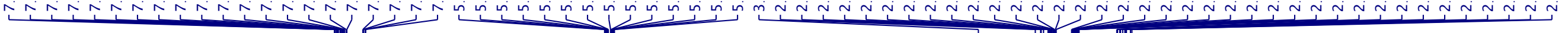
$\mathrm{CDCl} 3,500 \mathrm{MHz}$
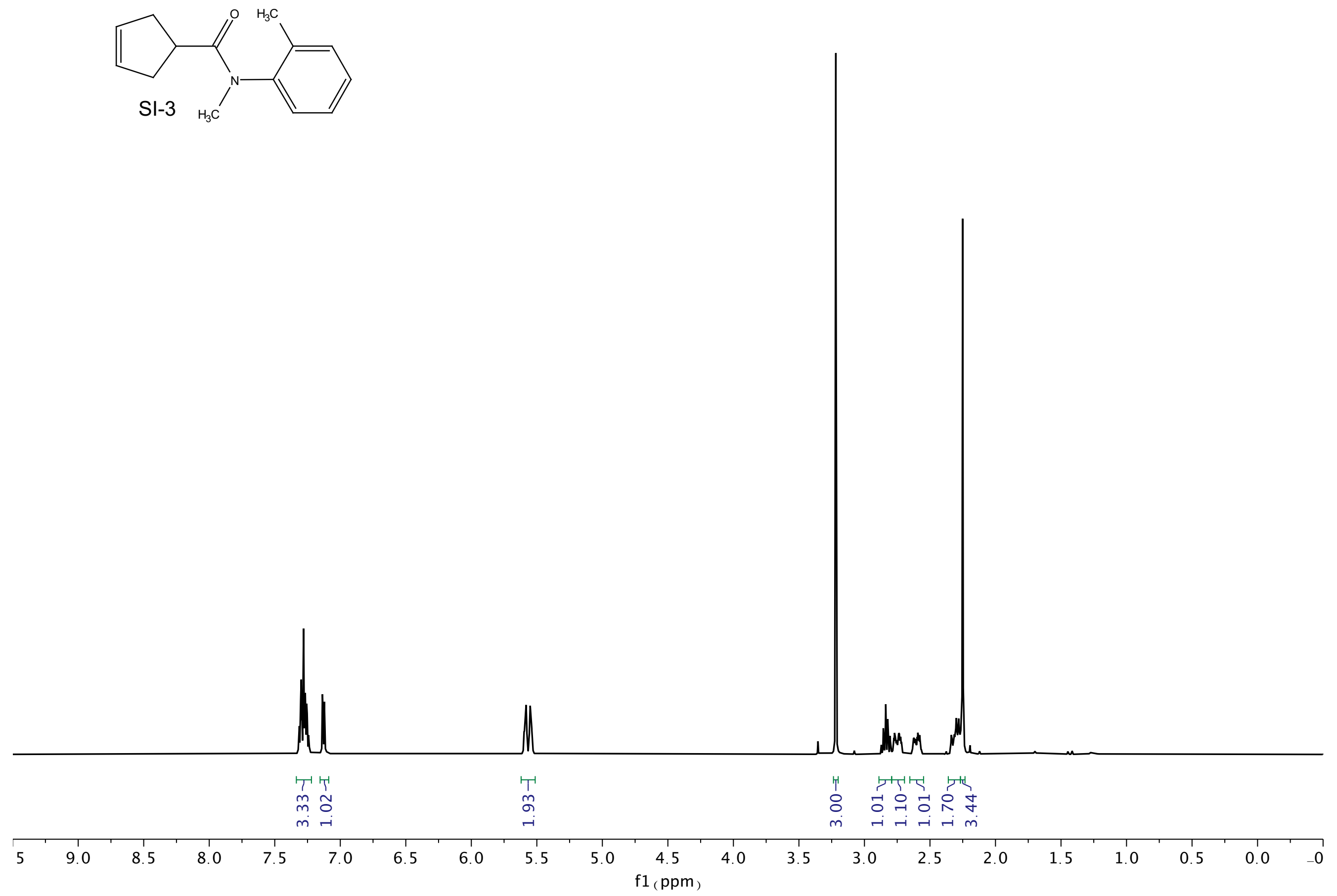

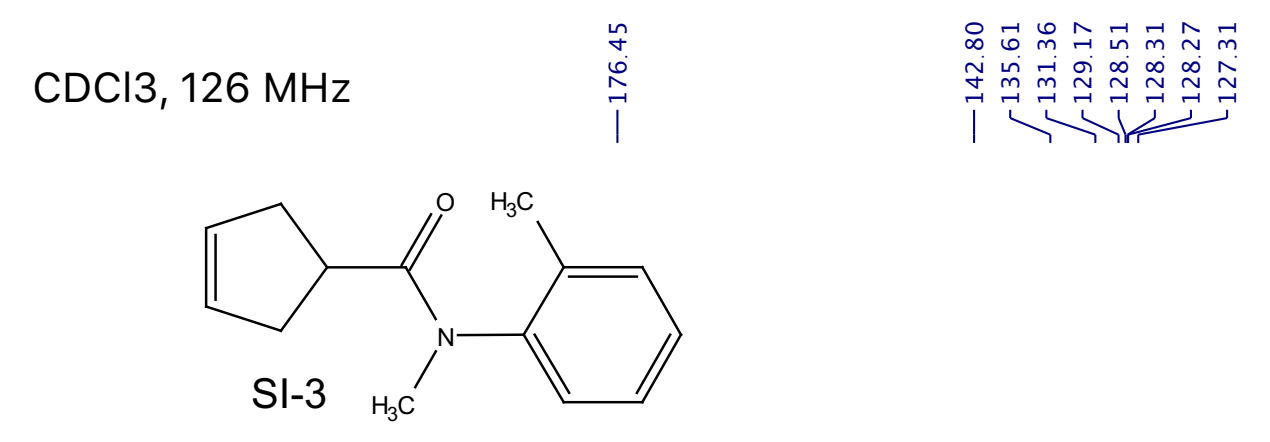

$\underbrace{\substack{0 \\ 0}}_{\substack{n \\ 0}}$

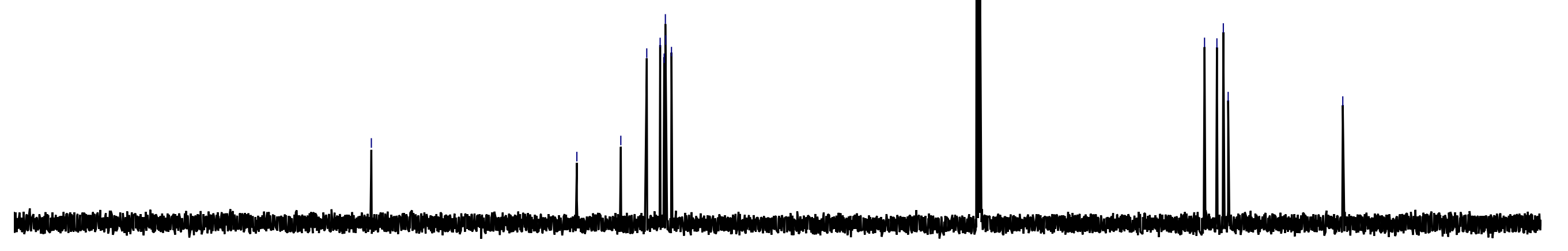

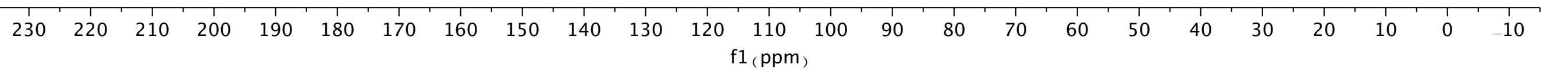


$\mathrm{CDCl} 3,400 \mathrm{MHz}$
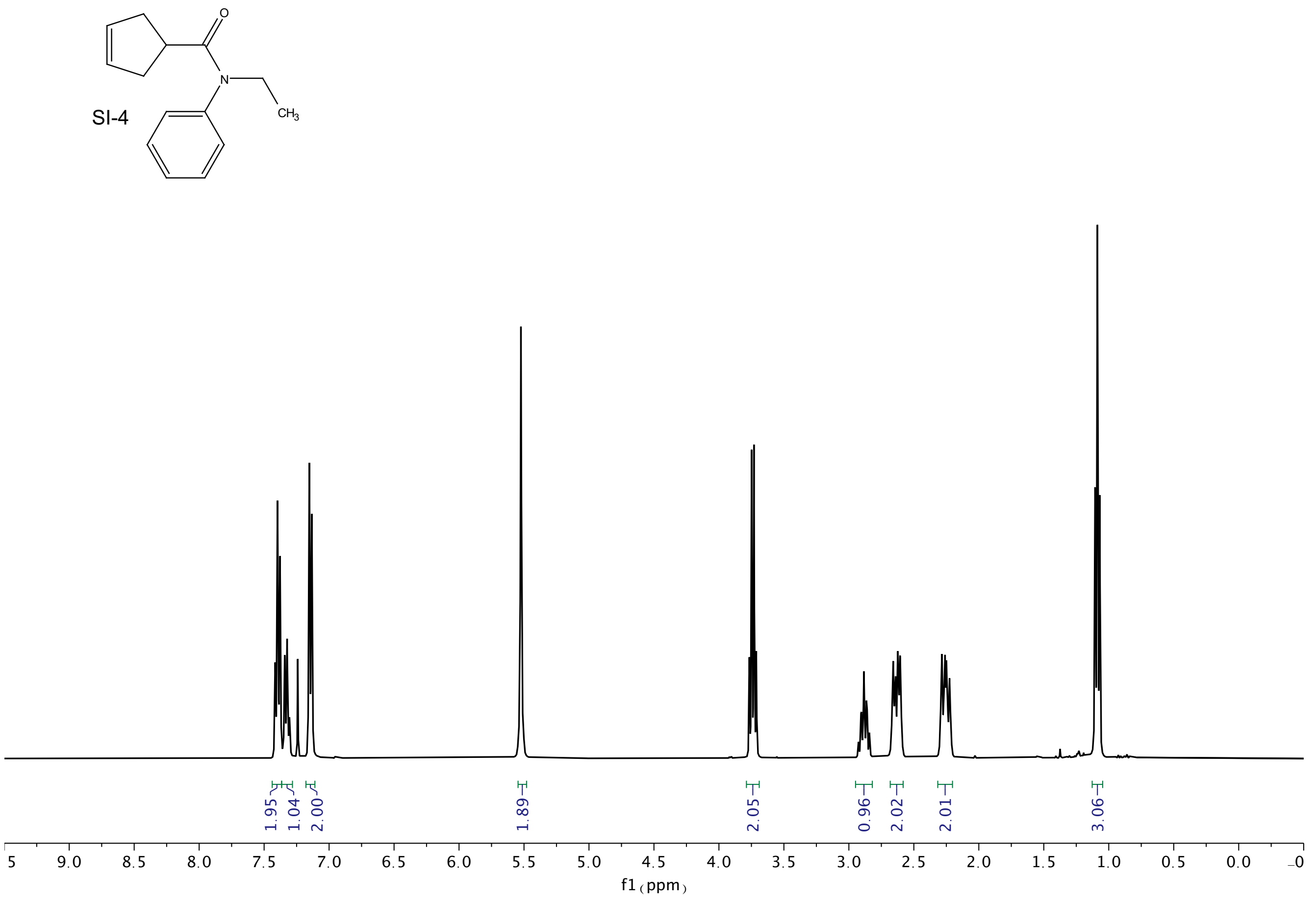


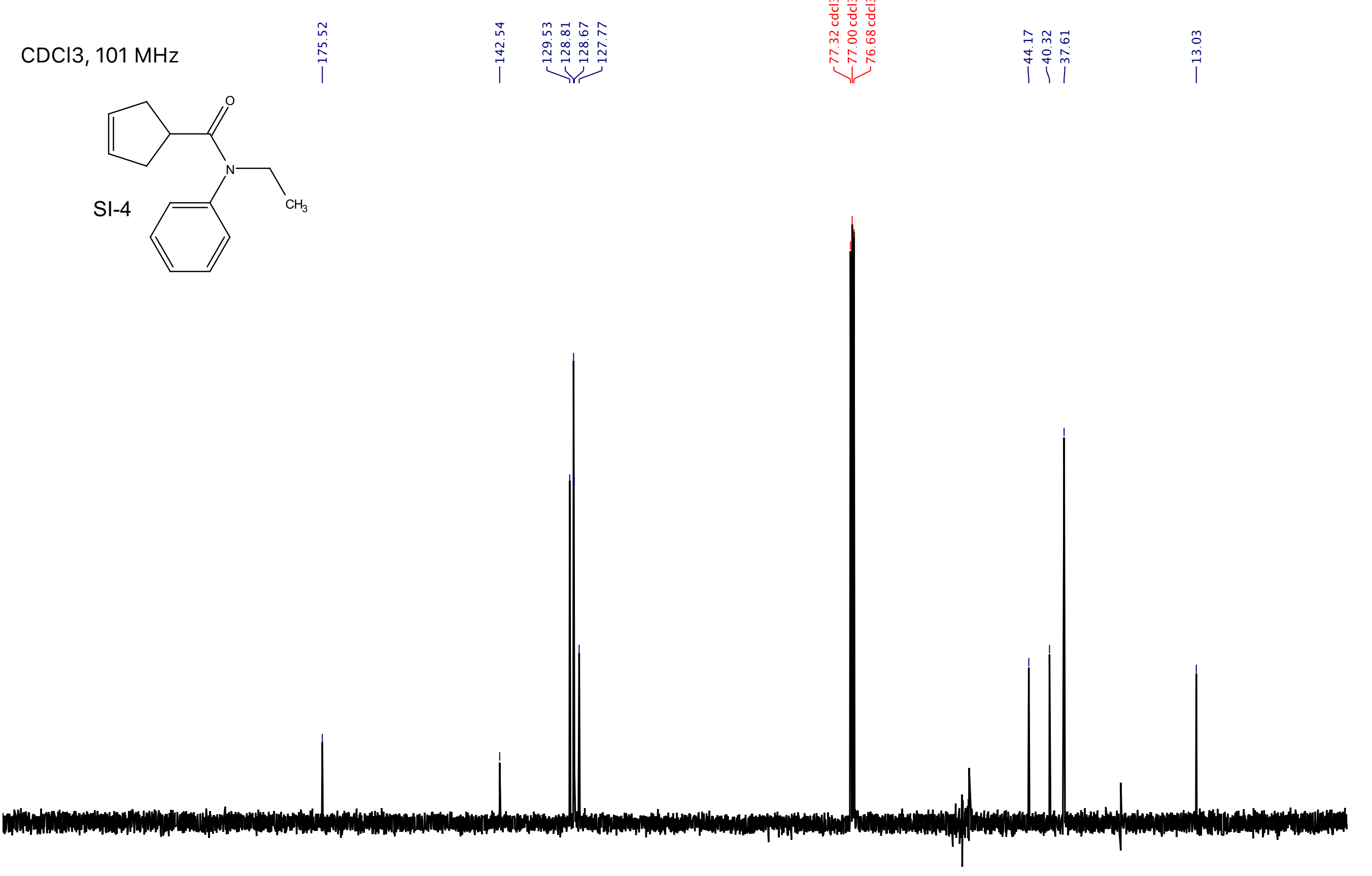

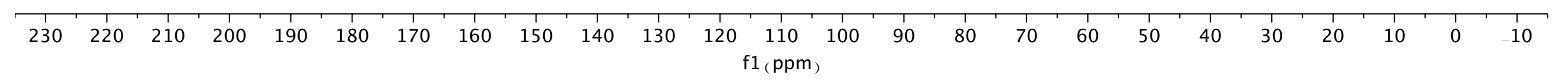


$\mathrm{CDCl} 3,400 \mathrm{MHz}$
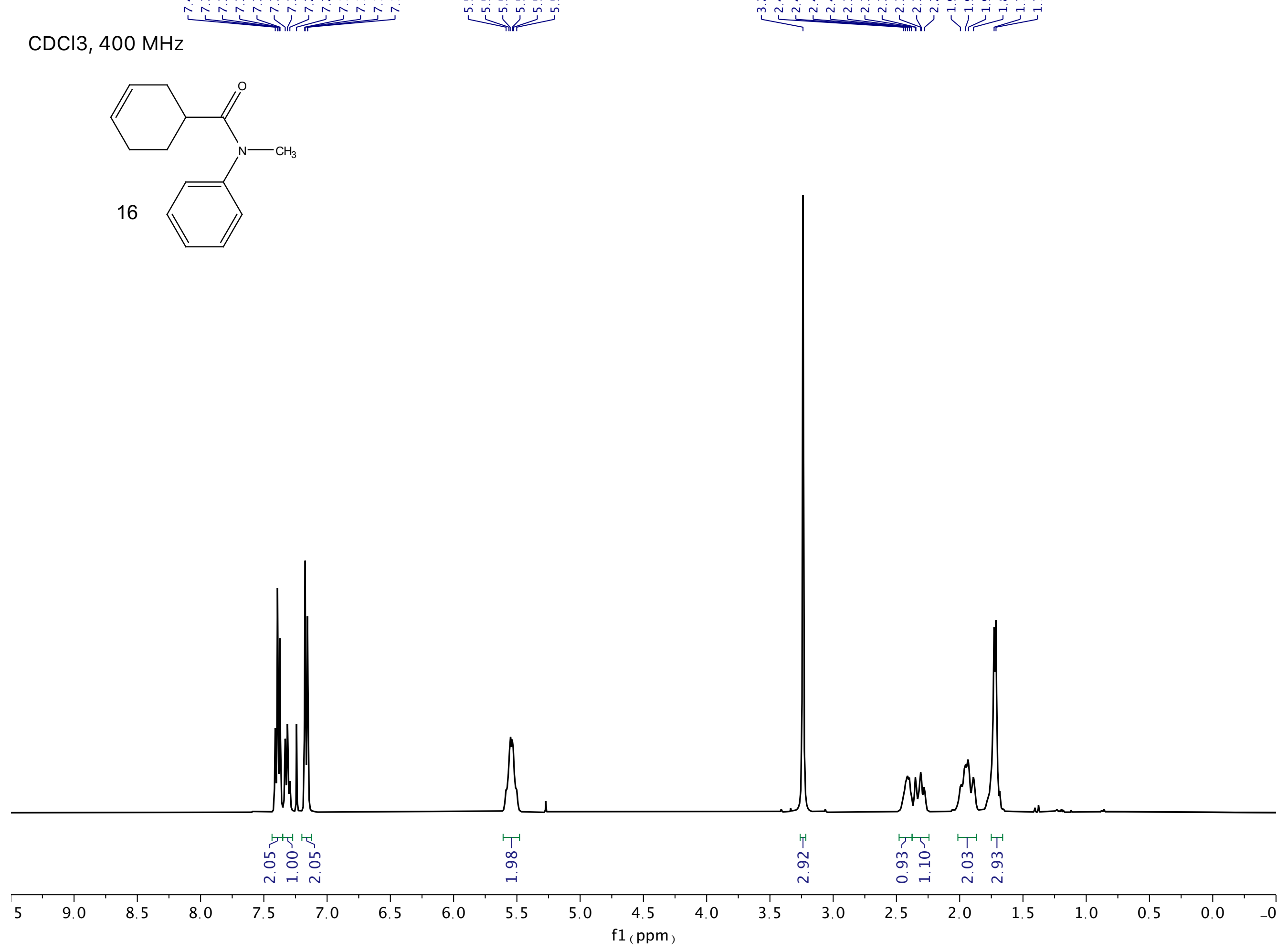

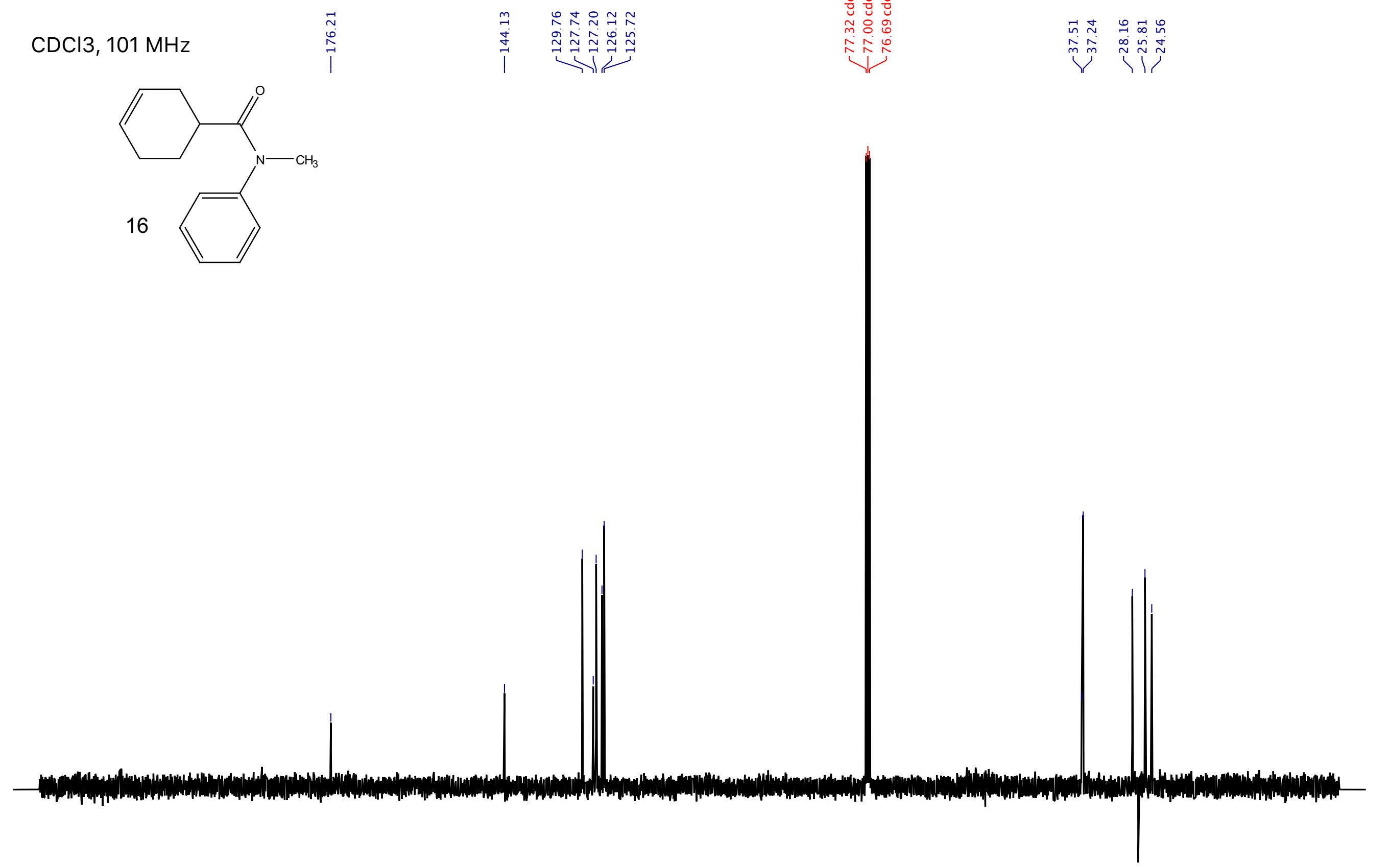

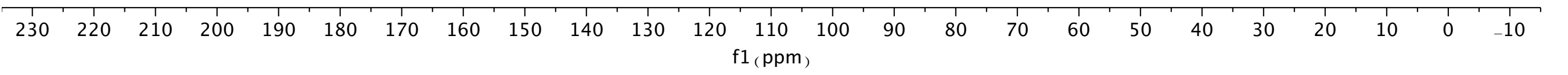




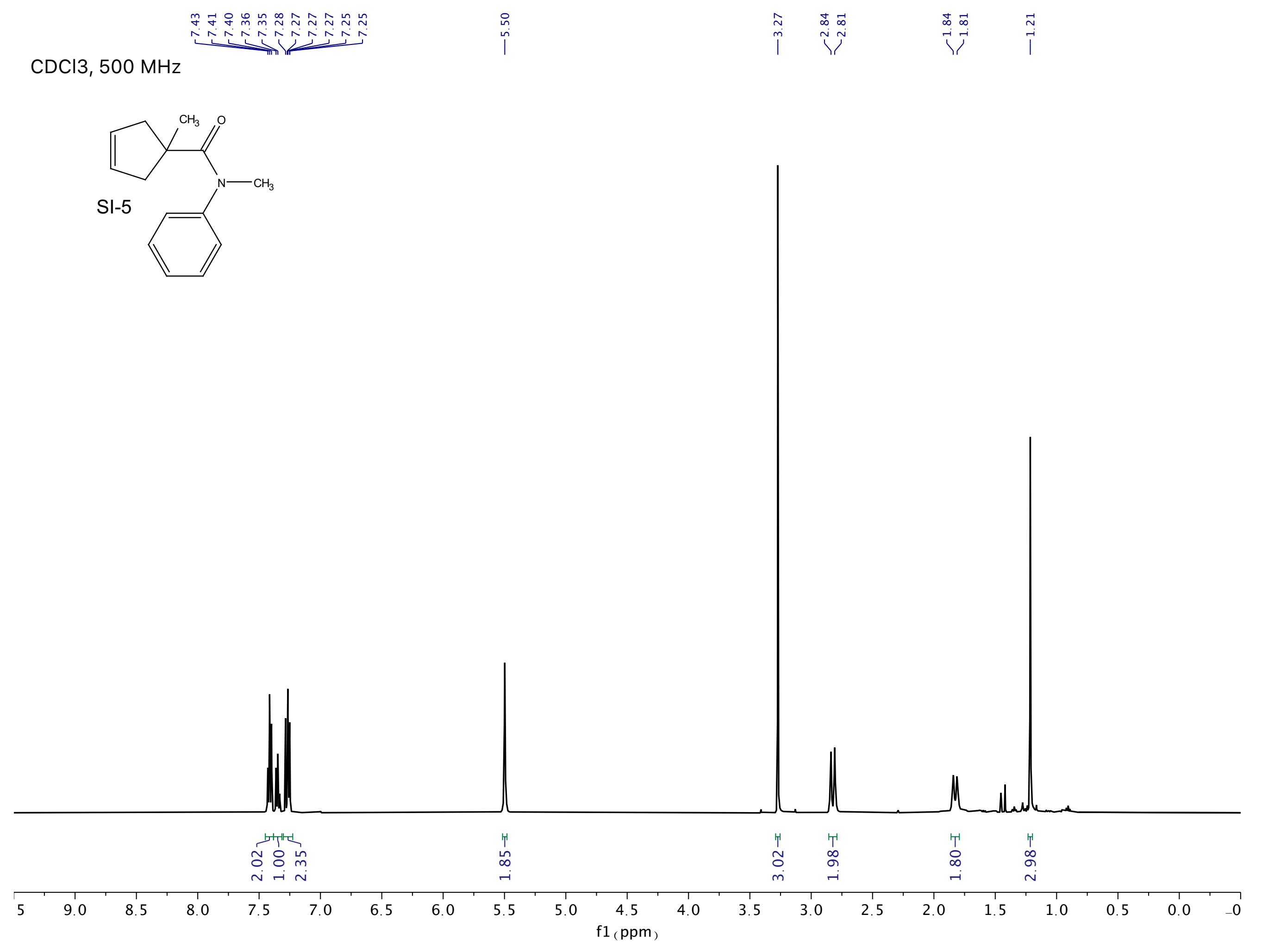




\section{$\mathrm{CDCl} 3,101 \mathrm{MHz}$}

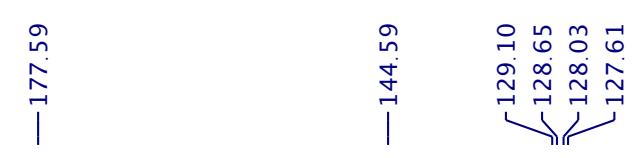
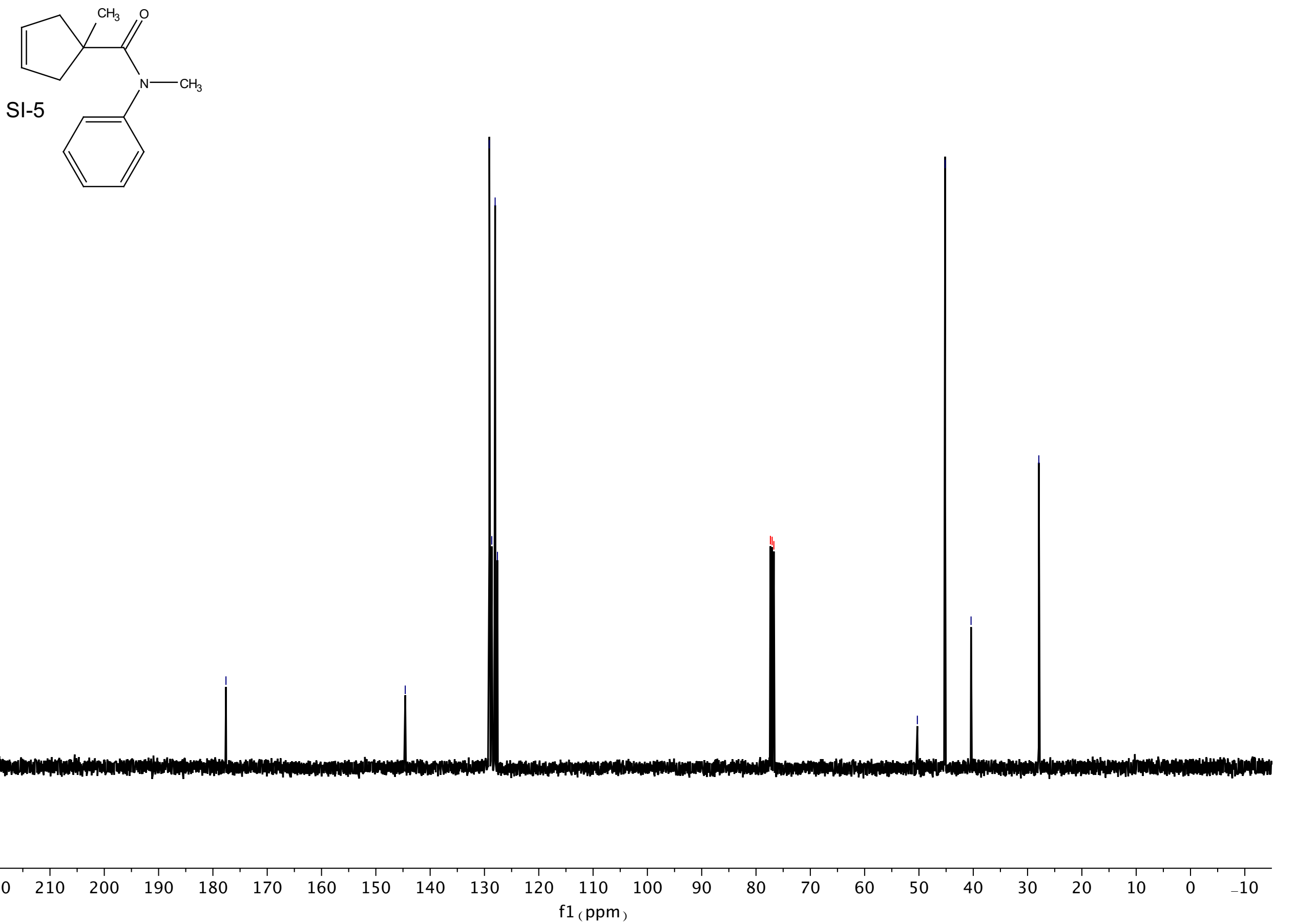
$\mathrm{CDCl} 3,400 \mathrm{MHz}$
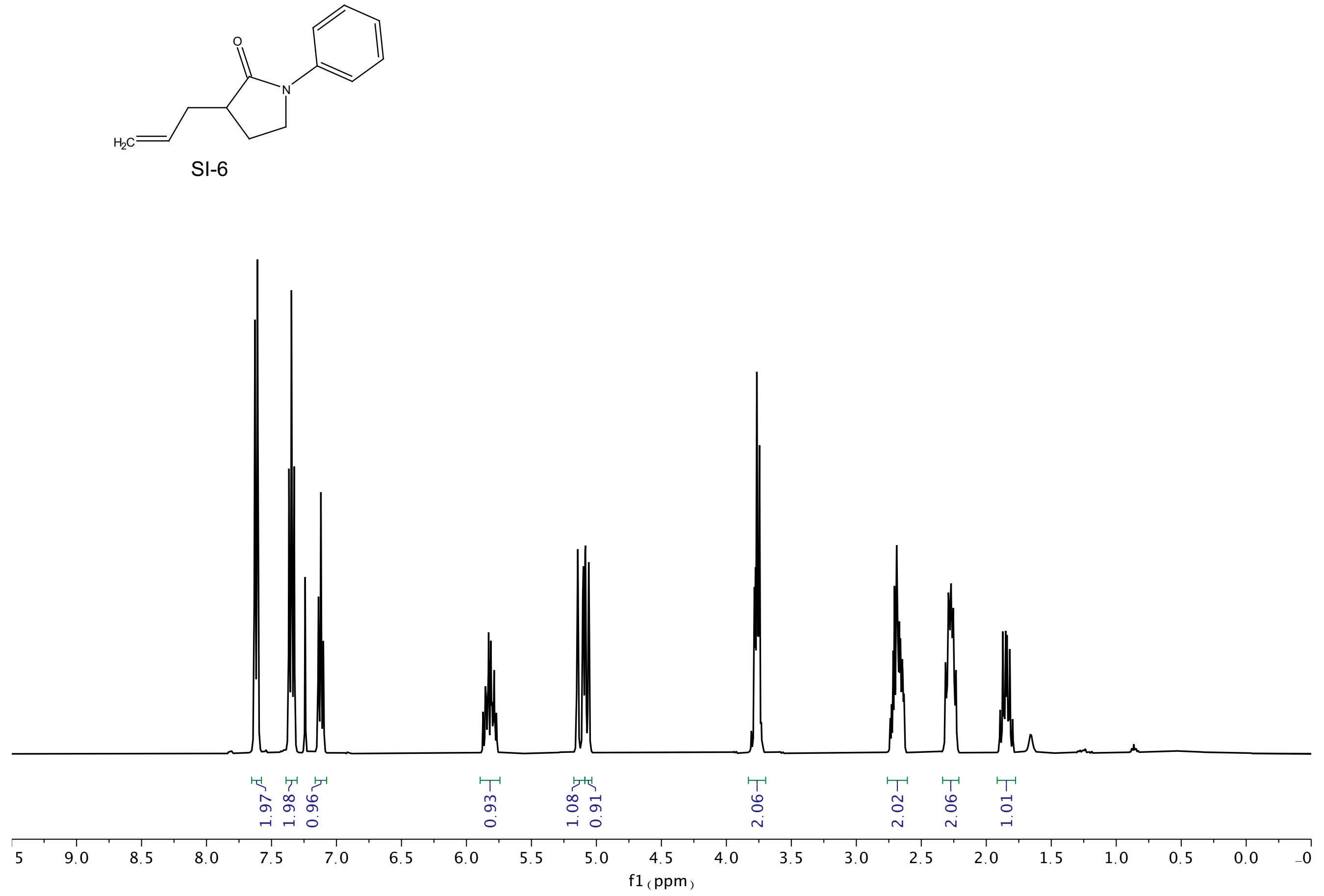


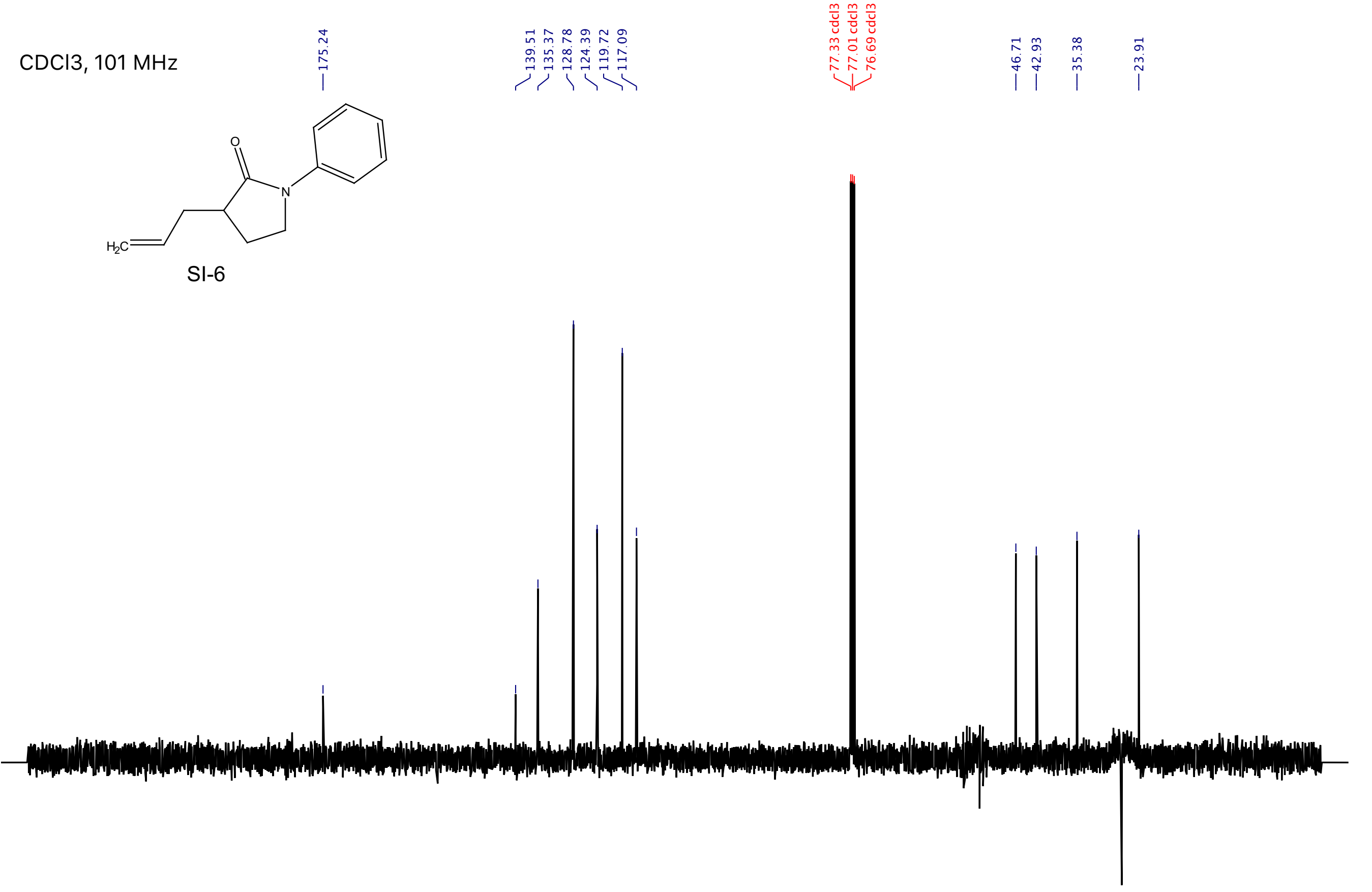

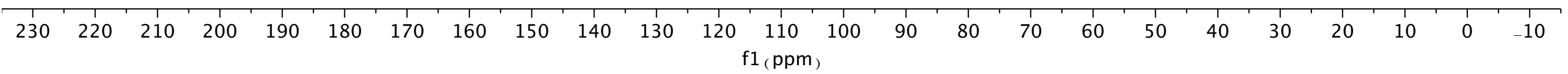



CDCl3, $500 \mathrm{MHz}$

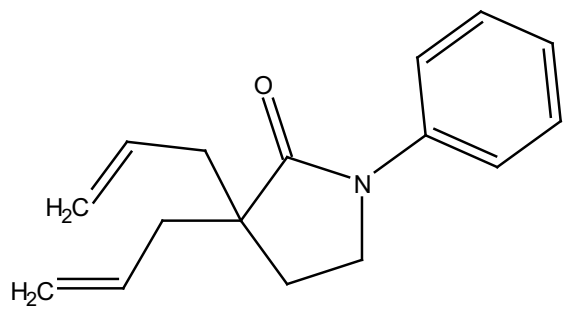

SI-7

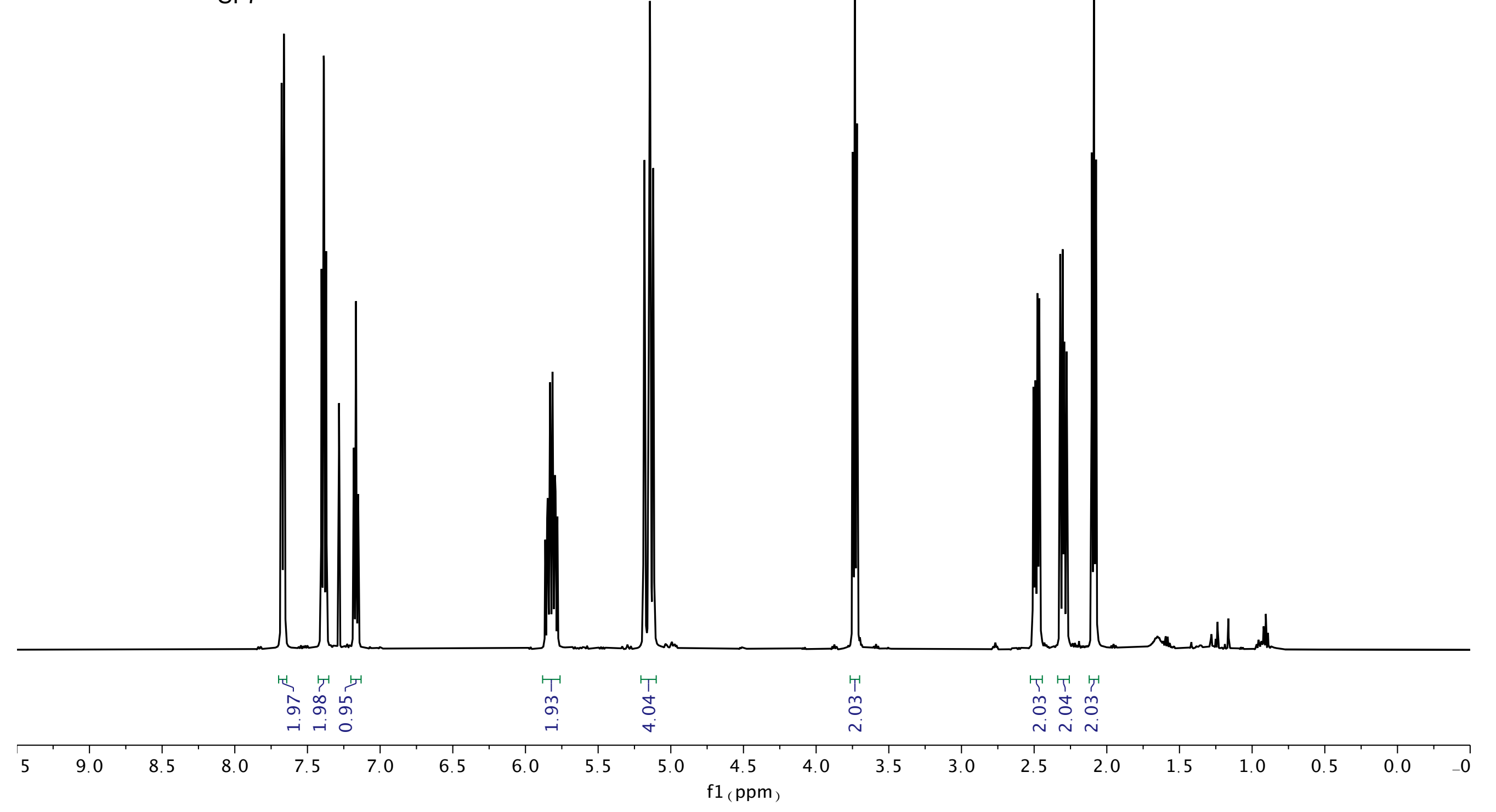




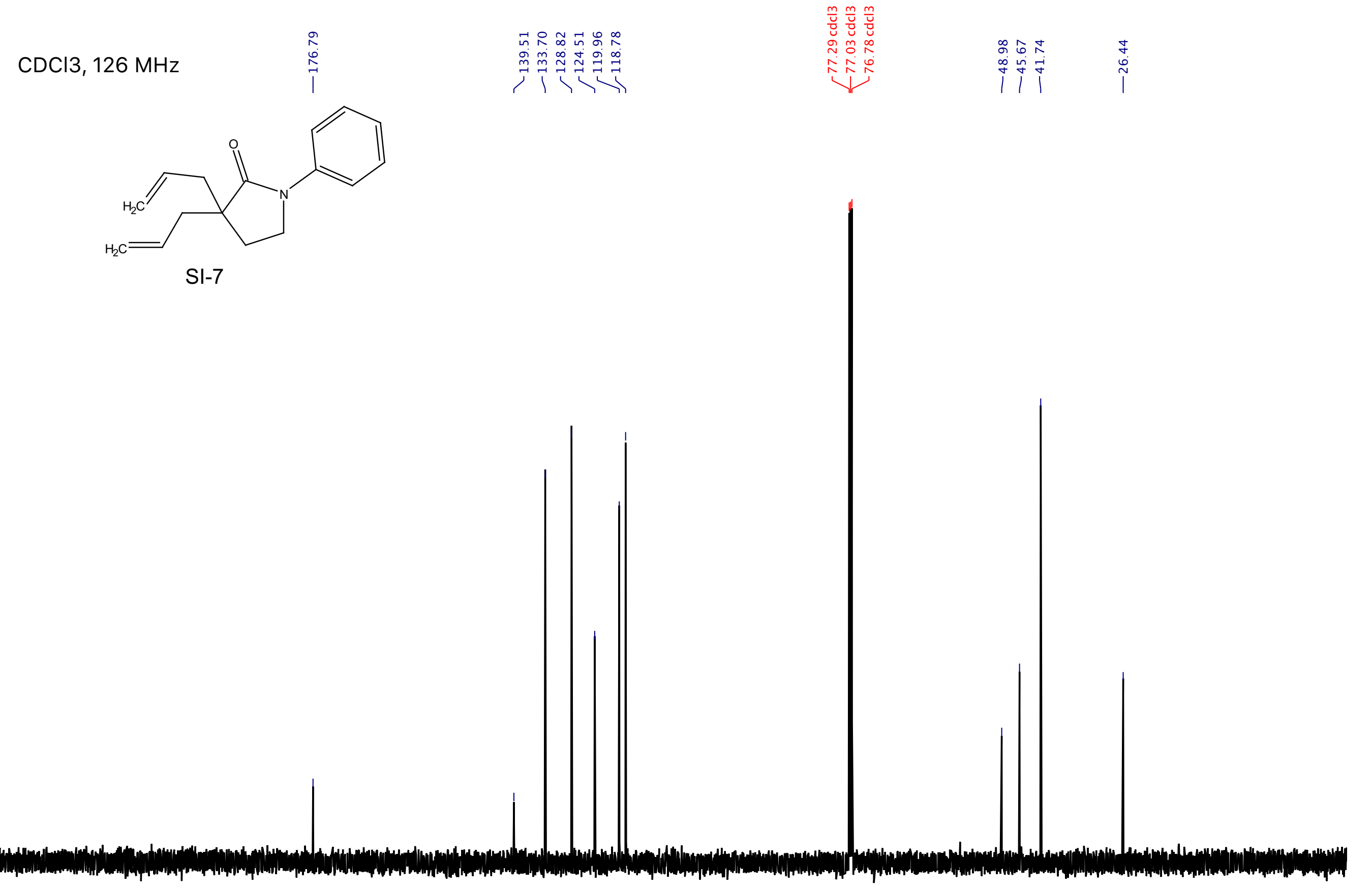

\begin{tabular}{|c|c|c|c|c|c|c|c|c|c|c|c|c|c|c|c|c|c|c|c|c|c|c|c|c|}
\hline 230 & 220 & 210 & 200 & 190 & 180 & 170 & 160 & 150 & 140 & 130 & 120 & $\begin{array}{r}110 \\
\mathrm{f} 1(\mathrm{ppn}\end{array}$ & 100 & 90 & 80 & 70 & 60 & 50 & 40 & 30 & 20 & 10 & 0 & -10 \\
\hline
\end{tabular}




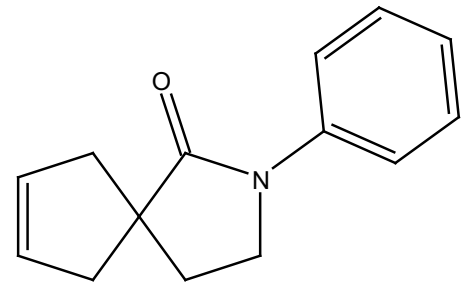

SI-8

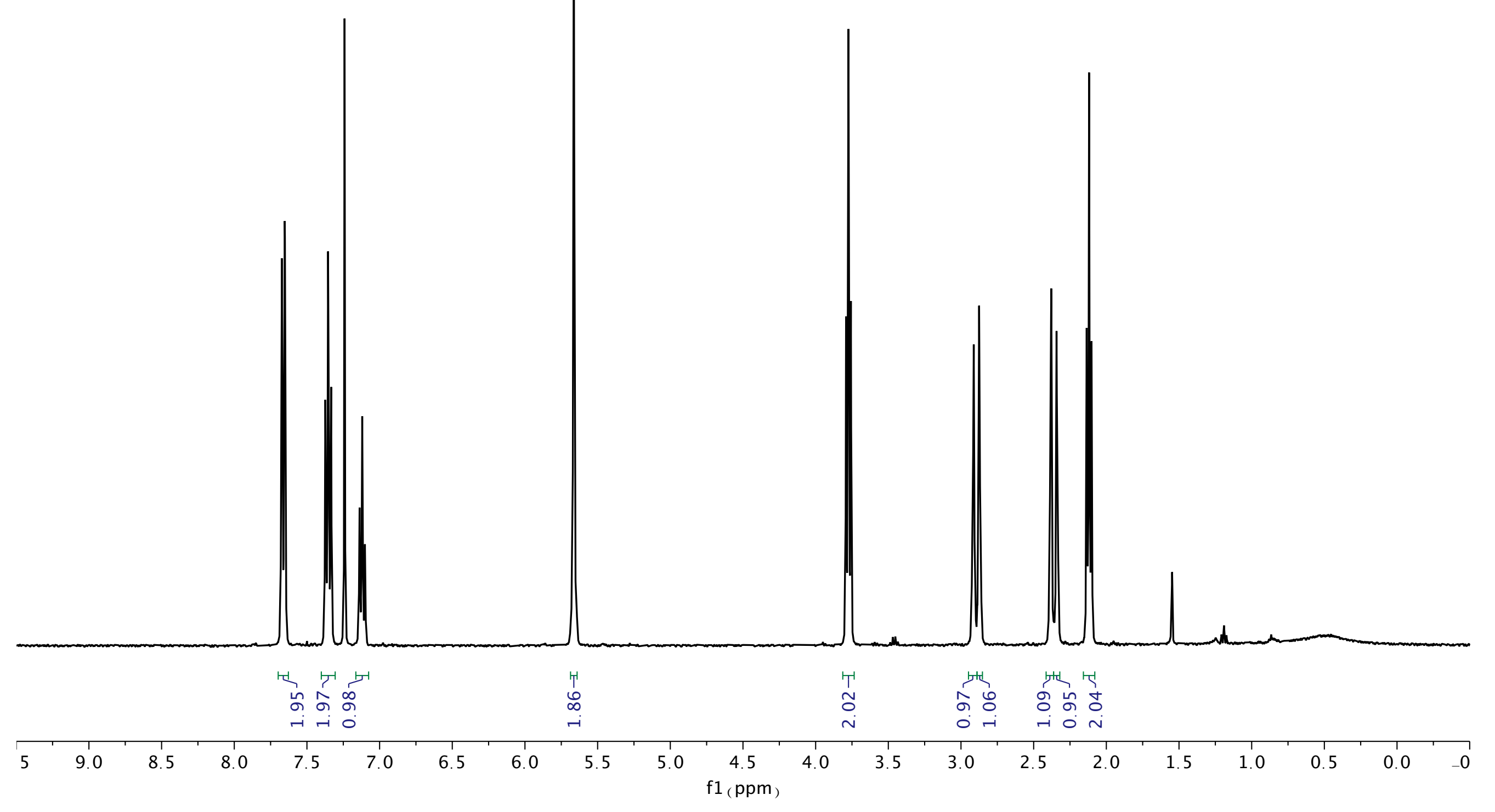




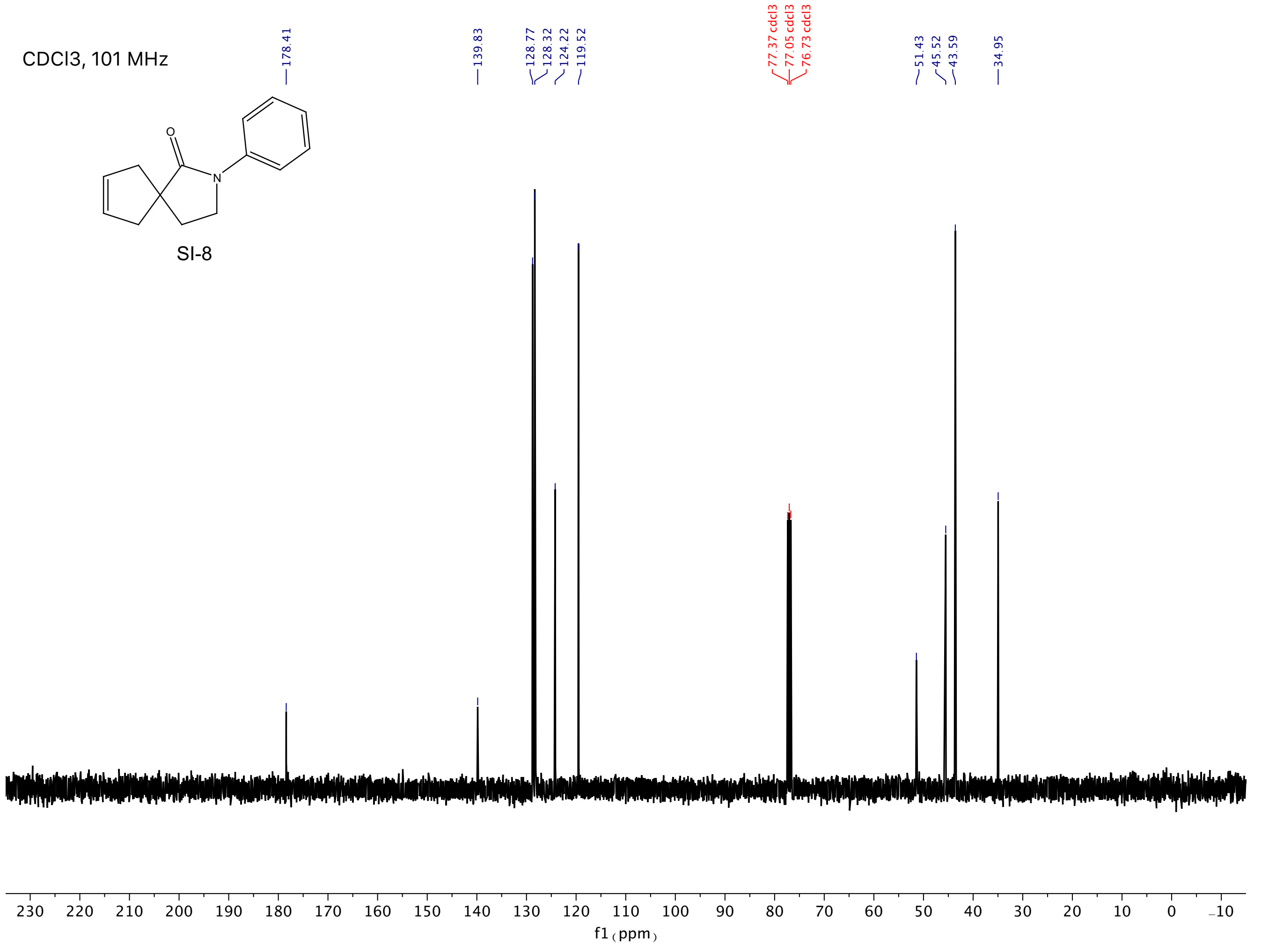



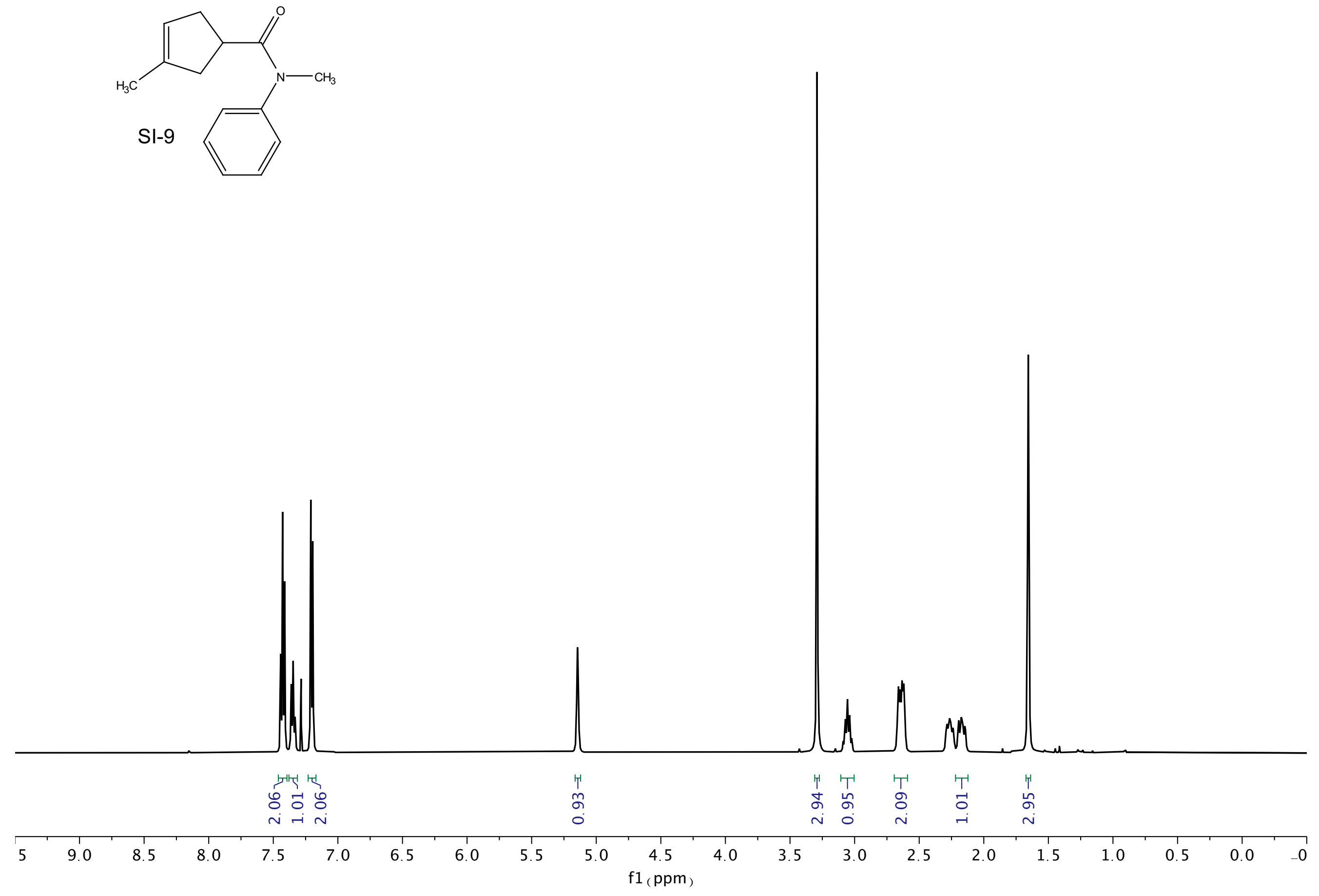

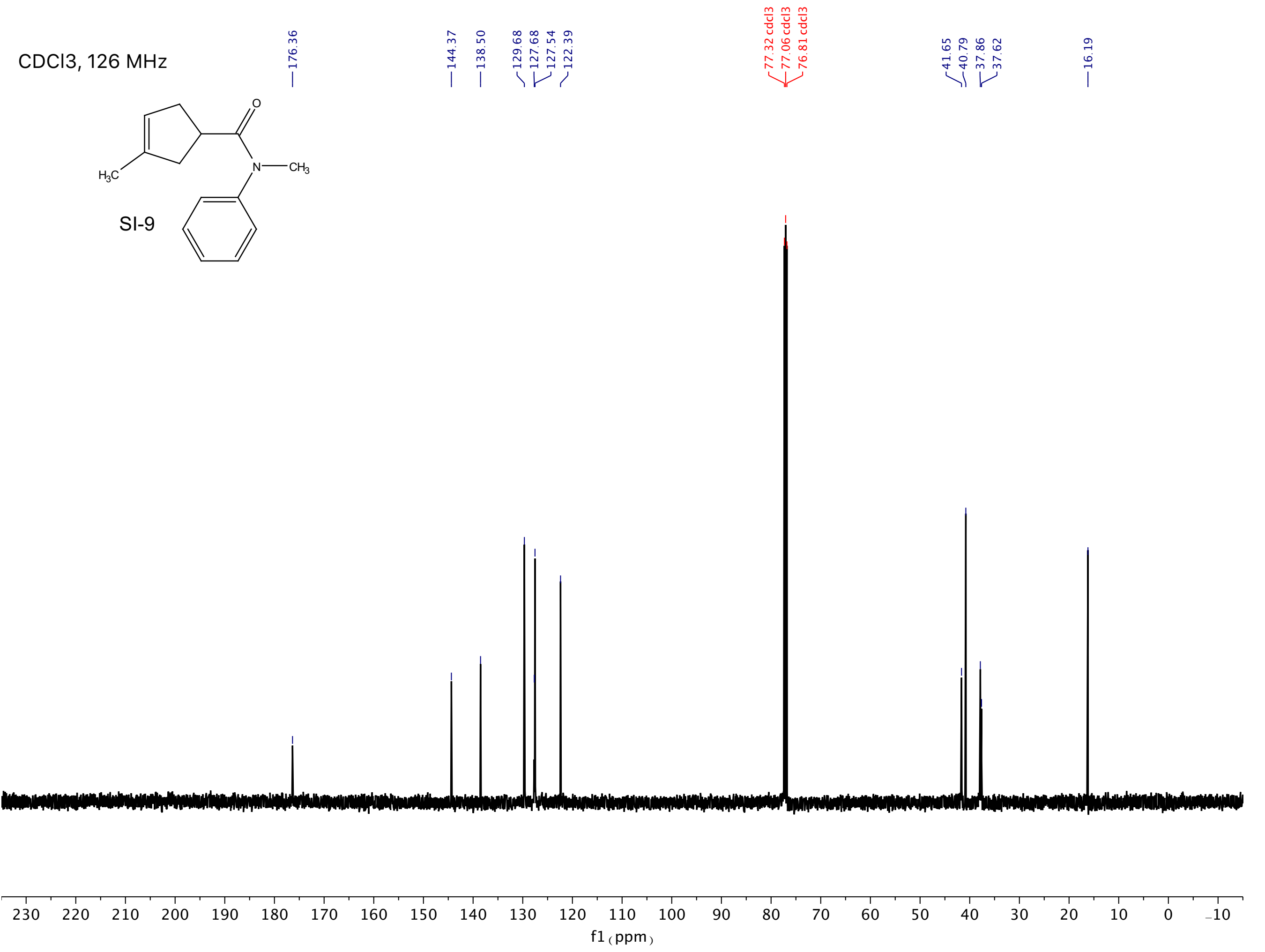

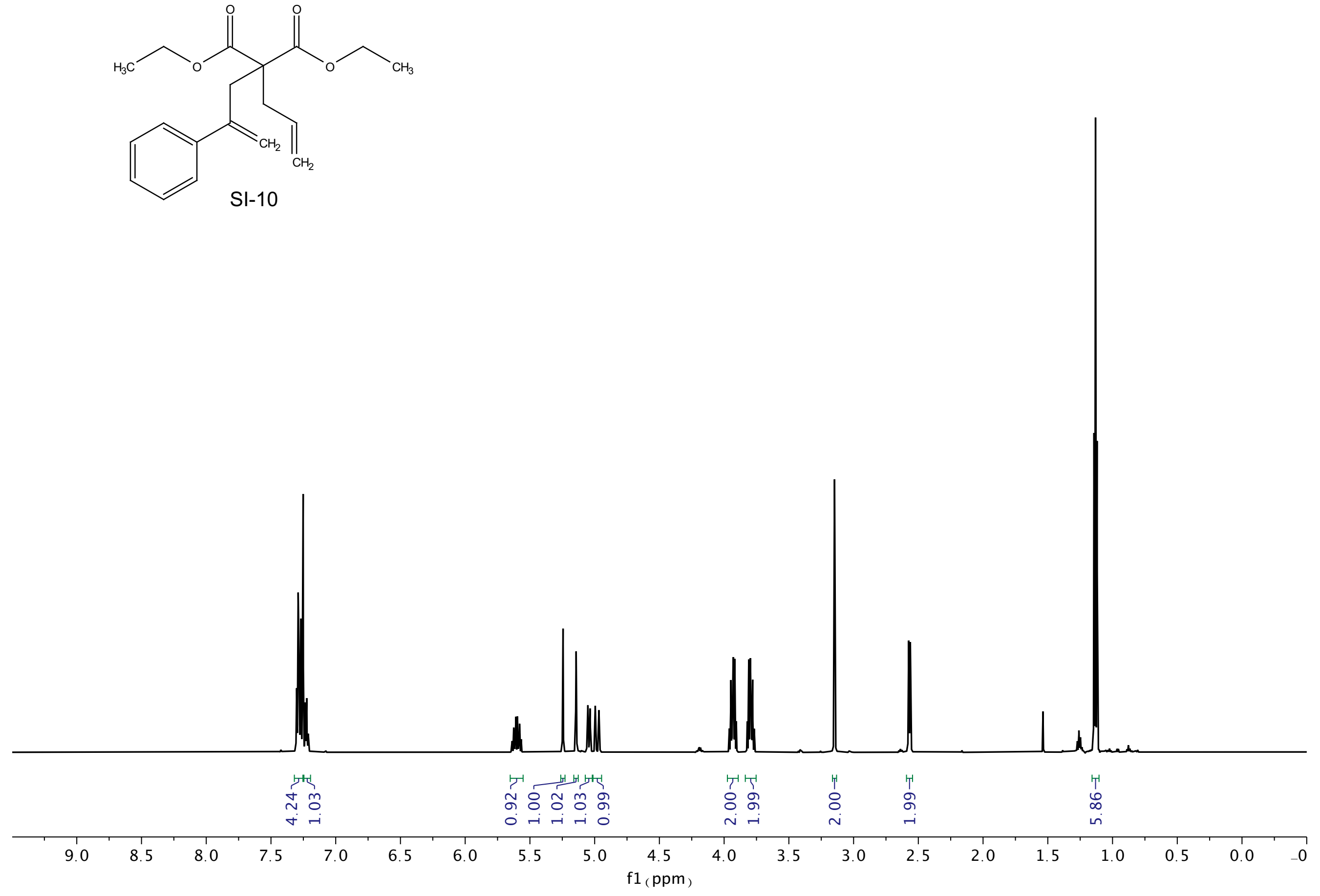


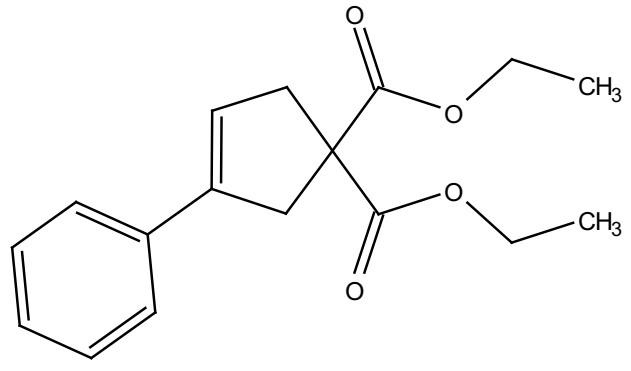

SI-11

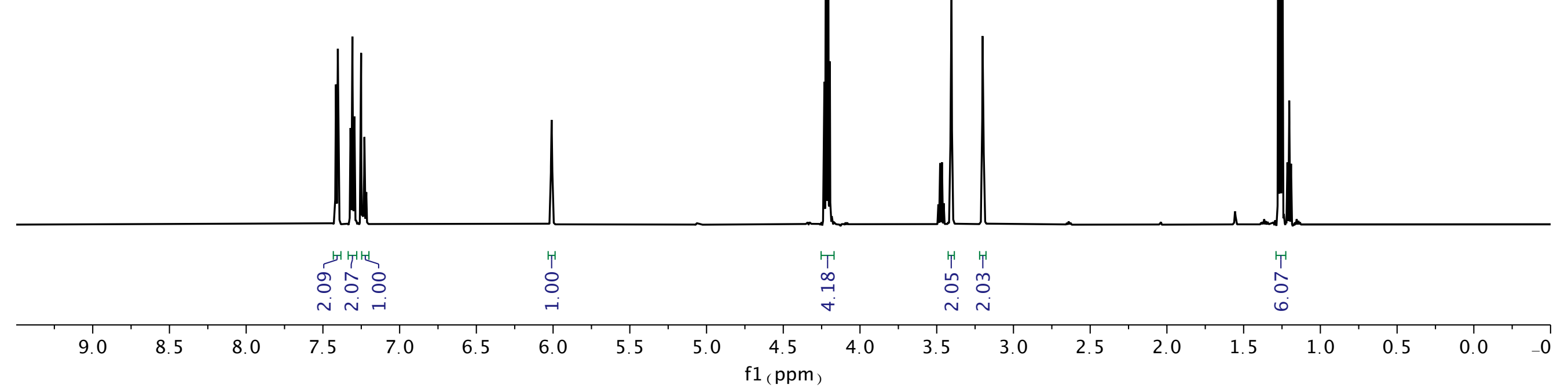



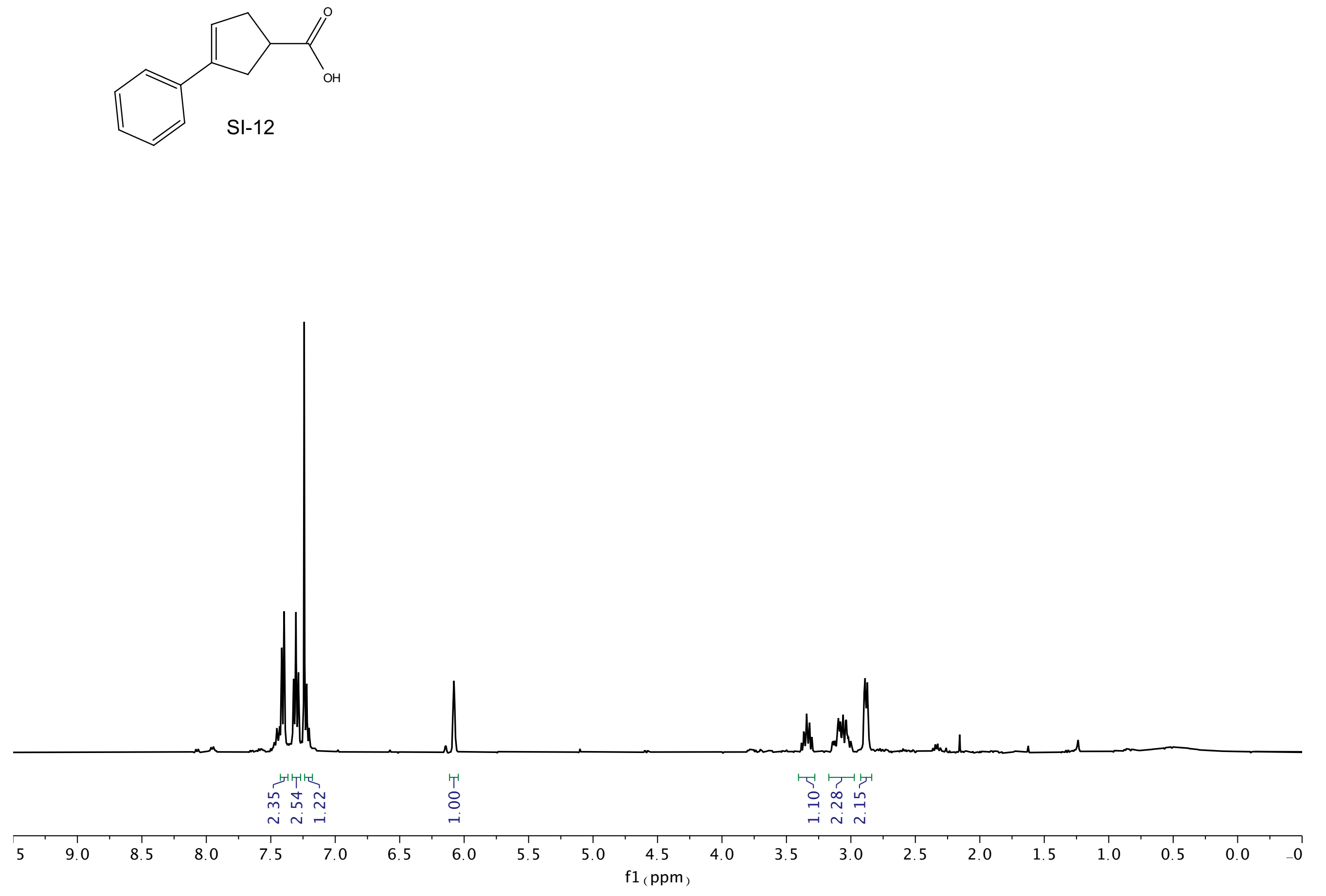
$\mathrm{CDCl} 3,400 \mathrm{MHz}$
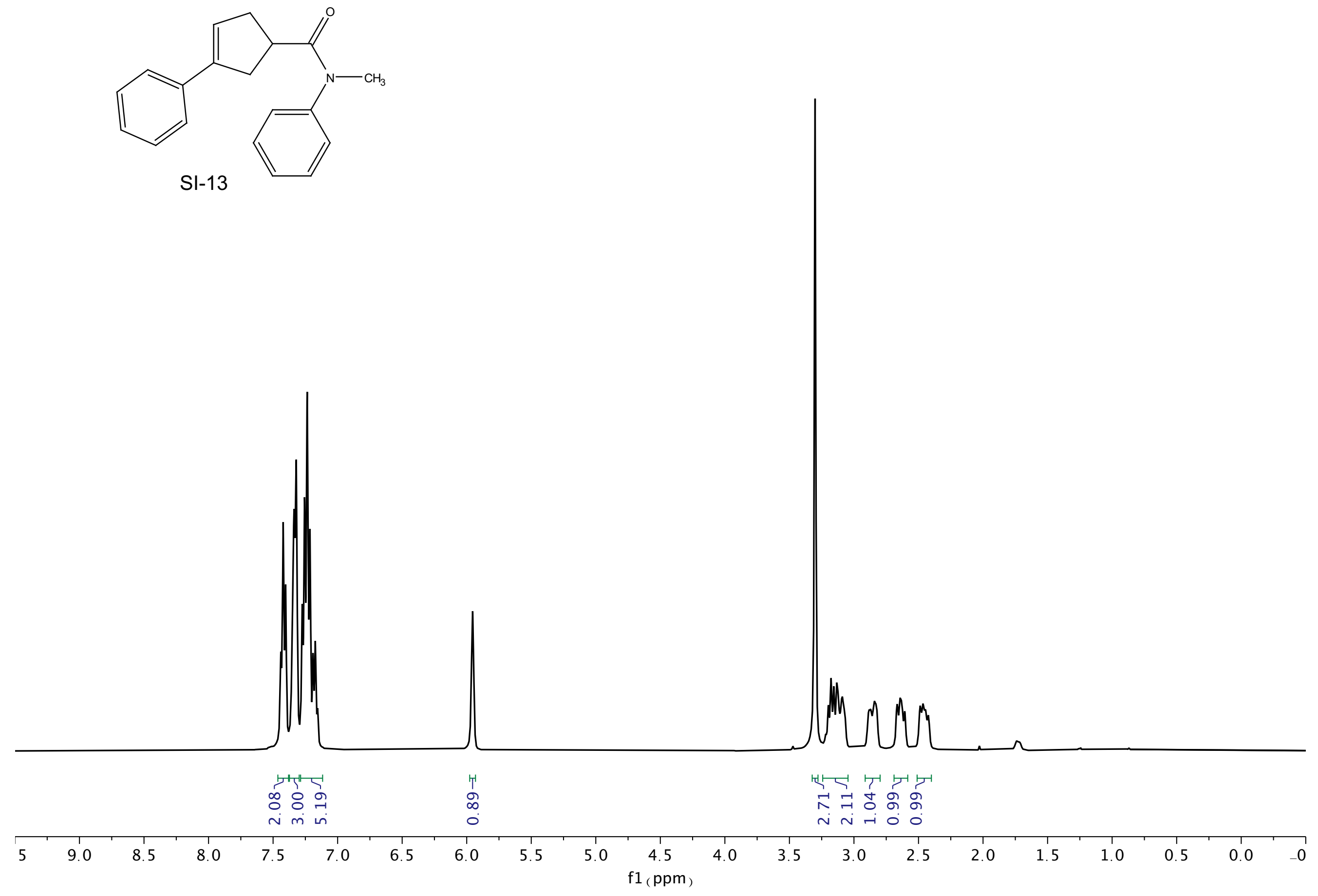


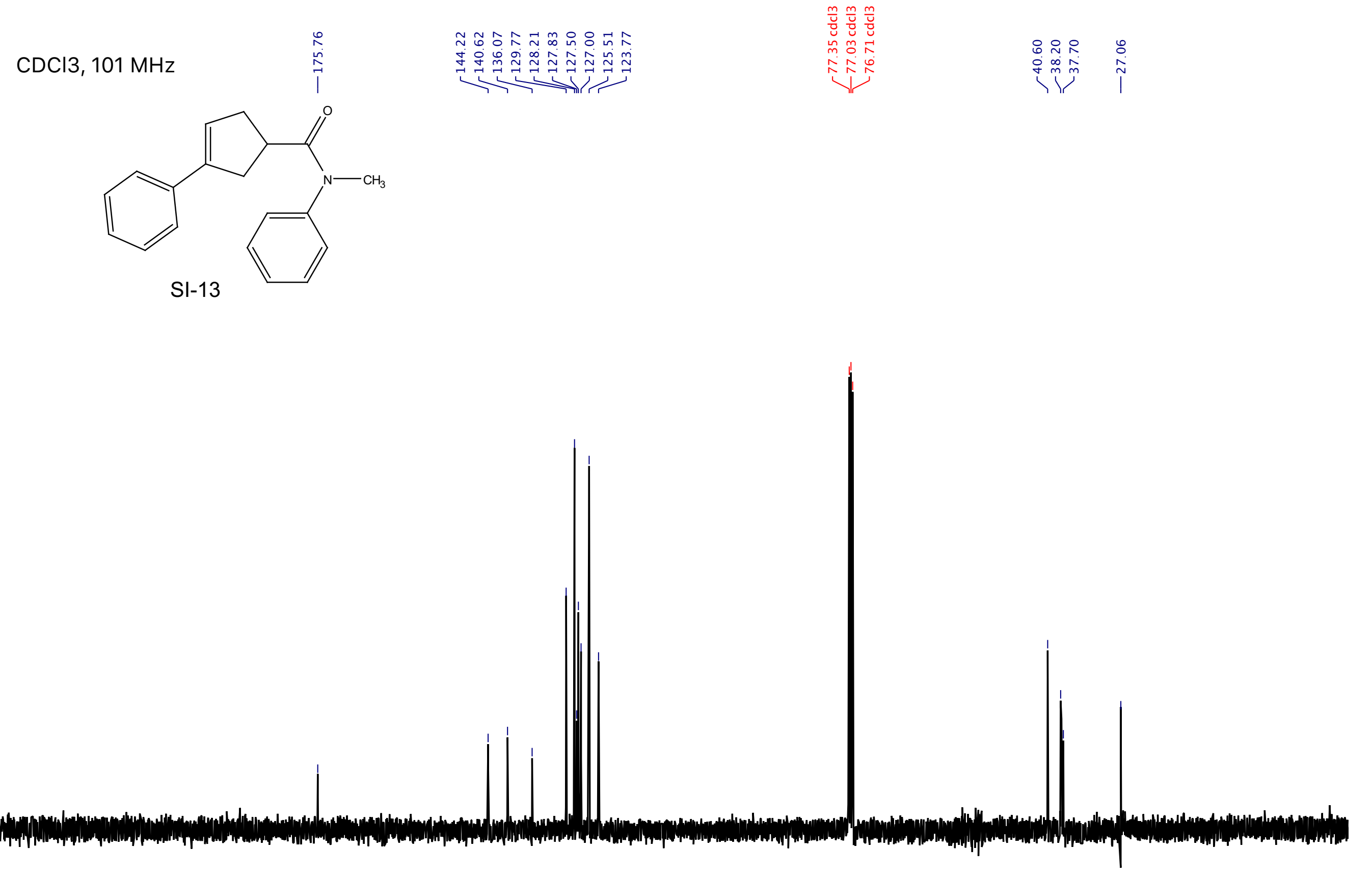

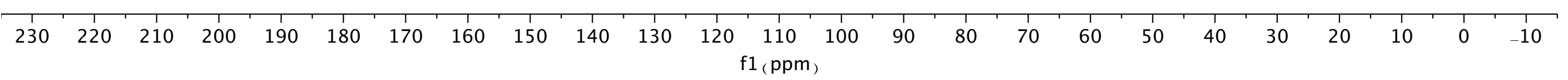



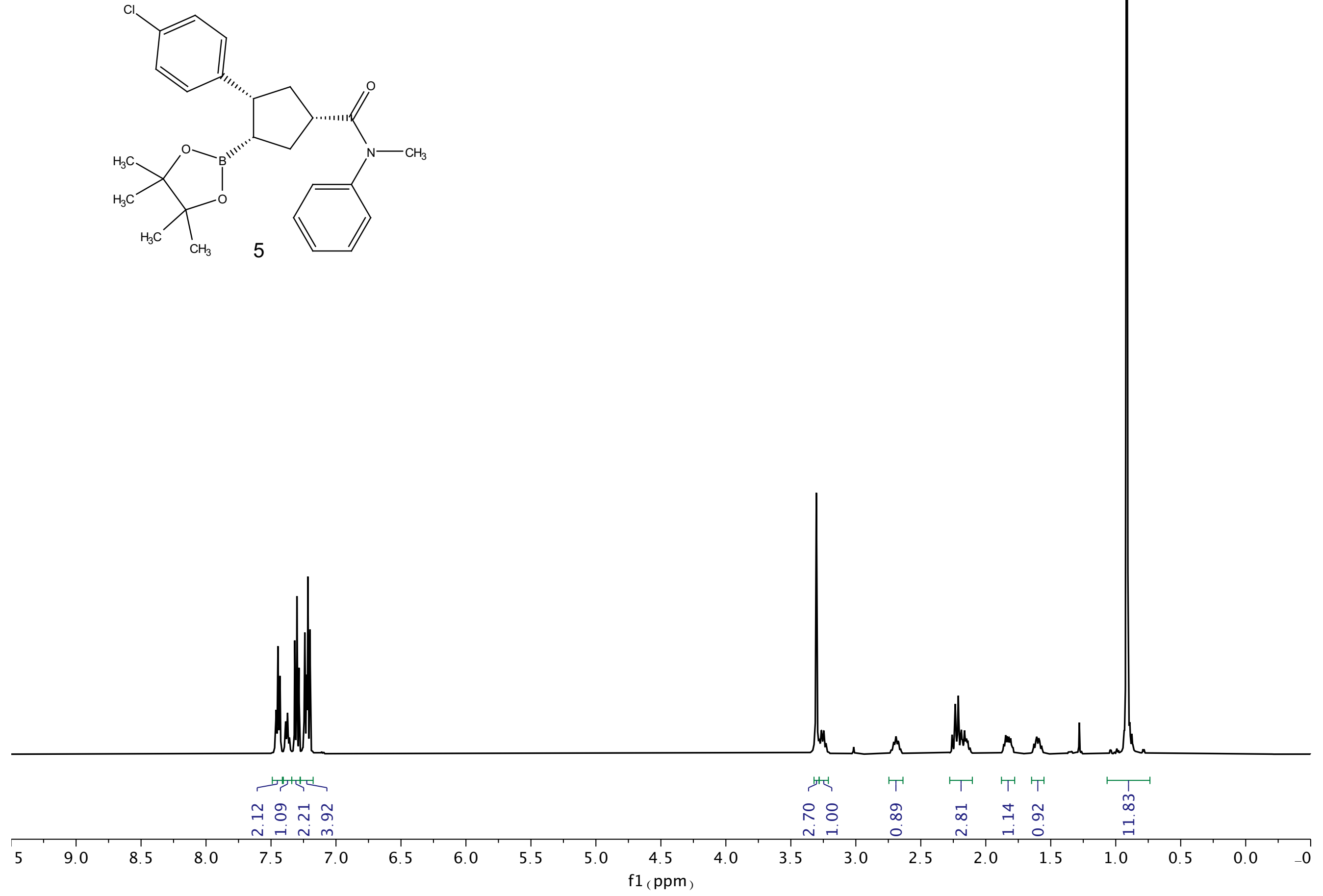


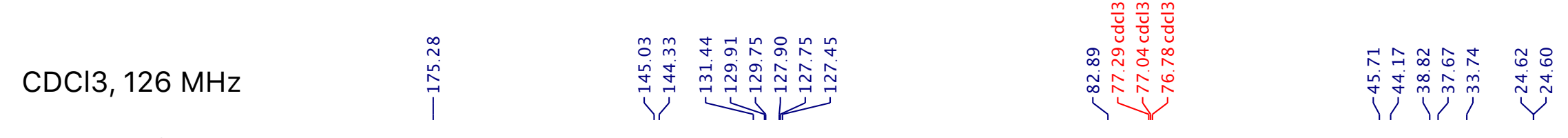
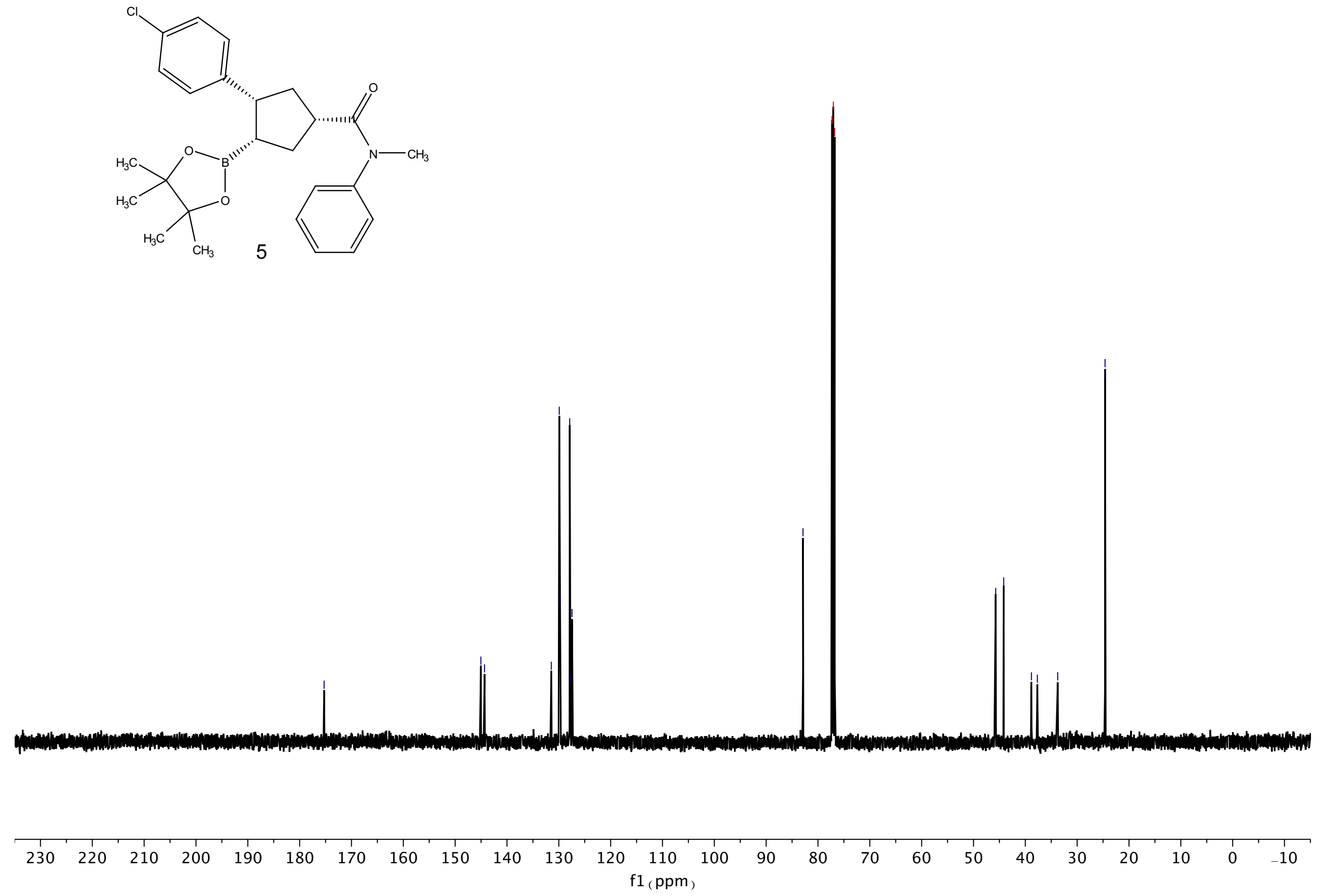
$\mathrm{CDCl} 3,500 \mathrm{MHz}$
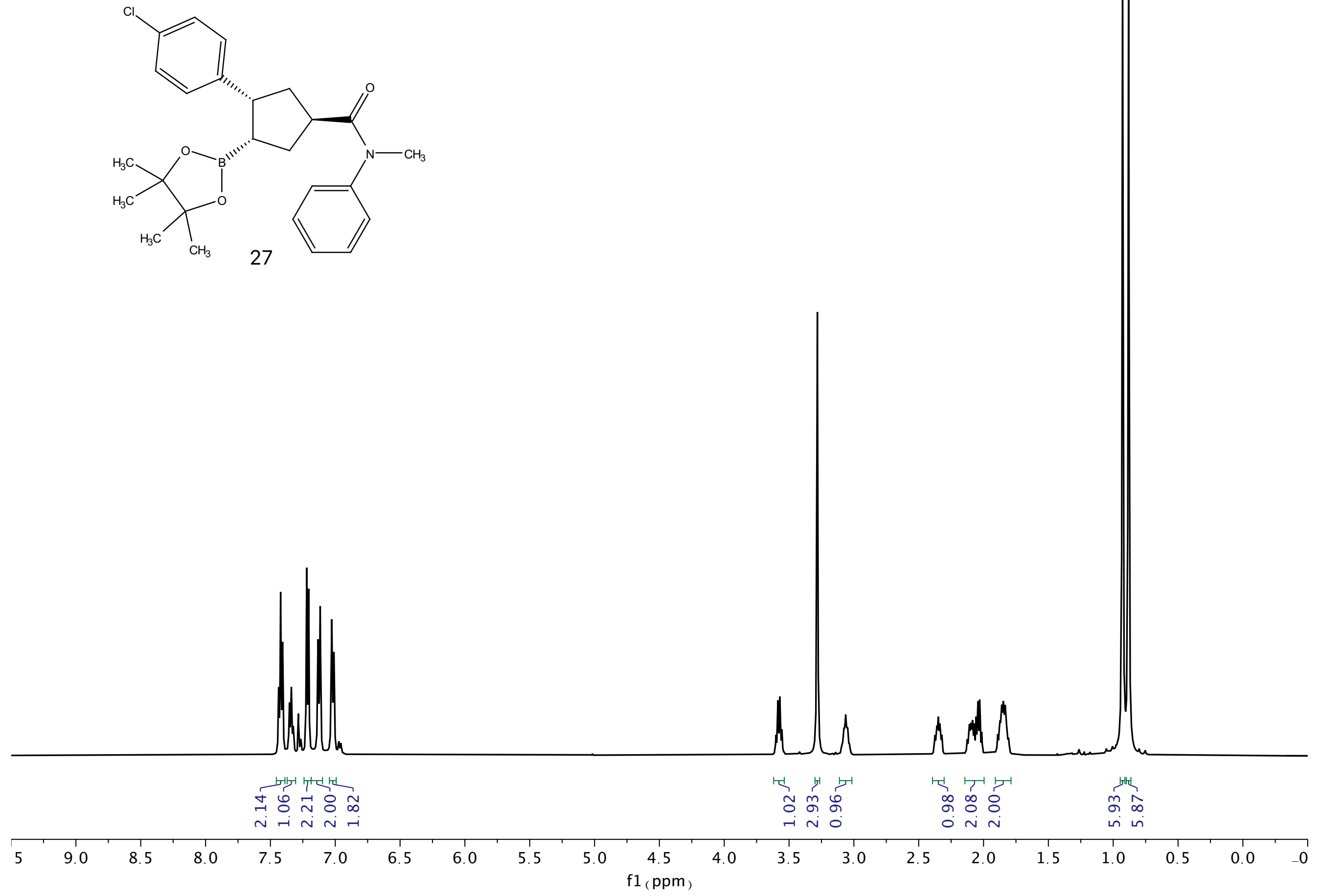


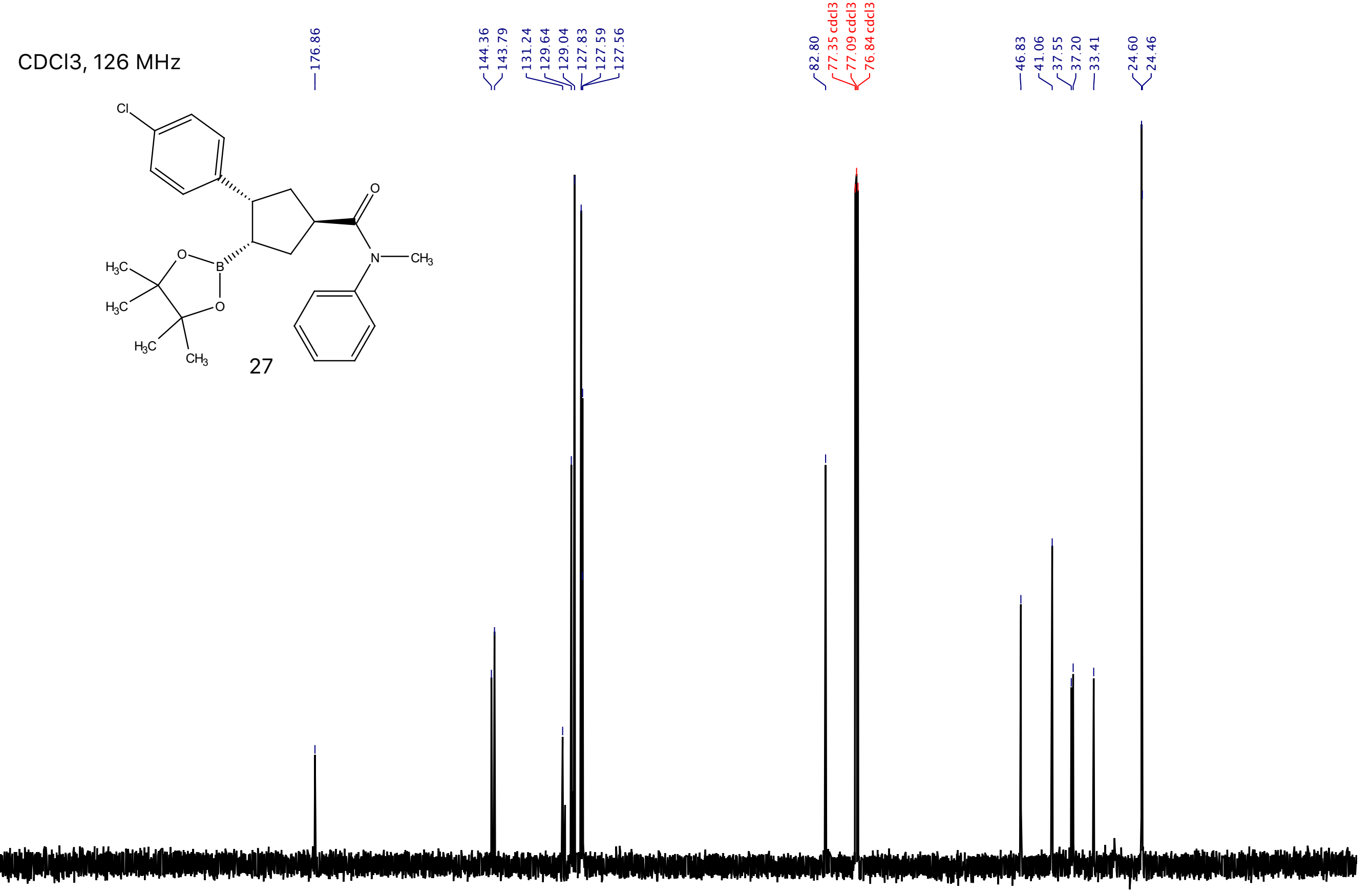

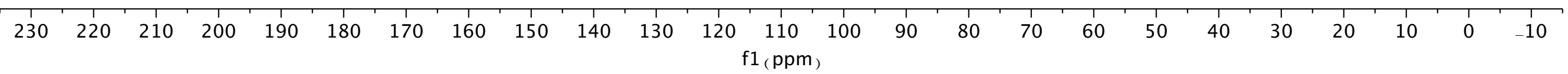



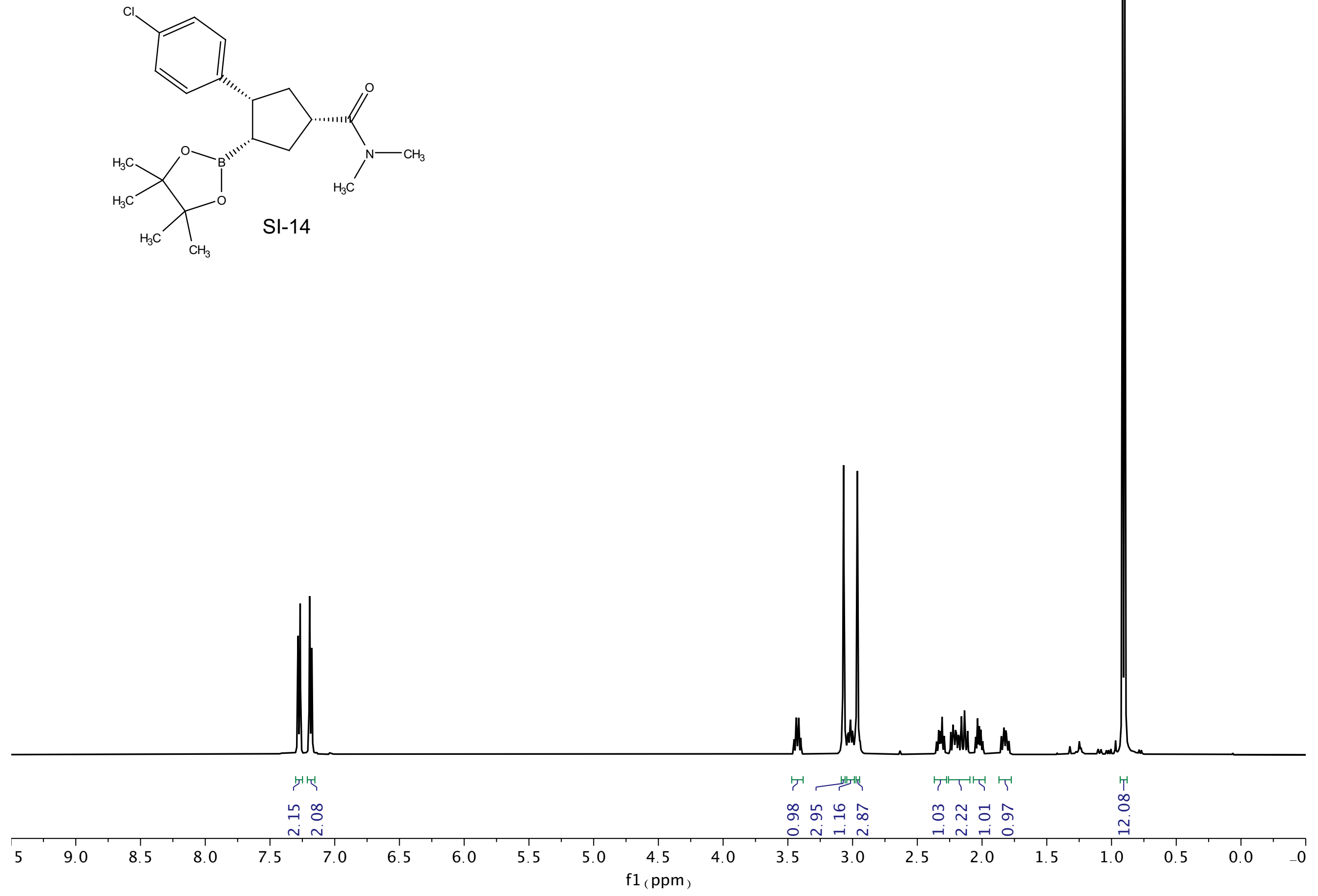


$\mathrm{CDCl}, 126 \mathrm{MHz}$

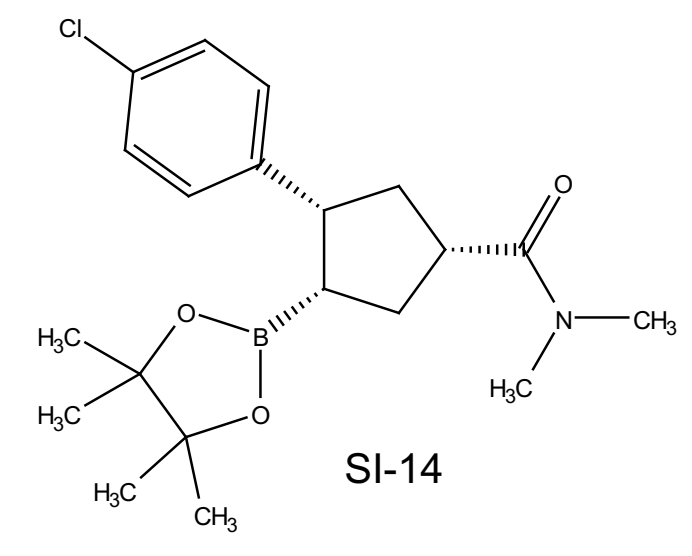



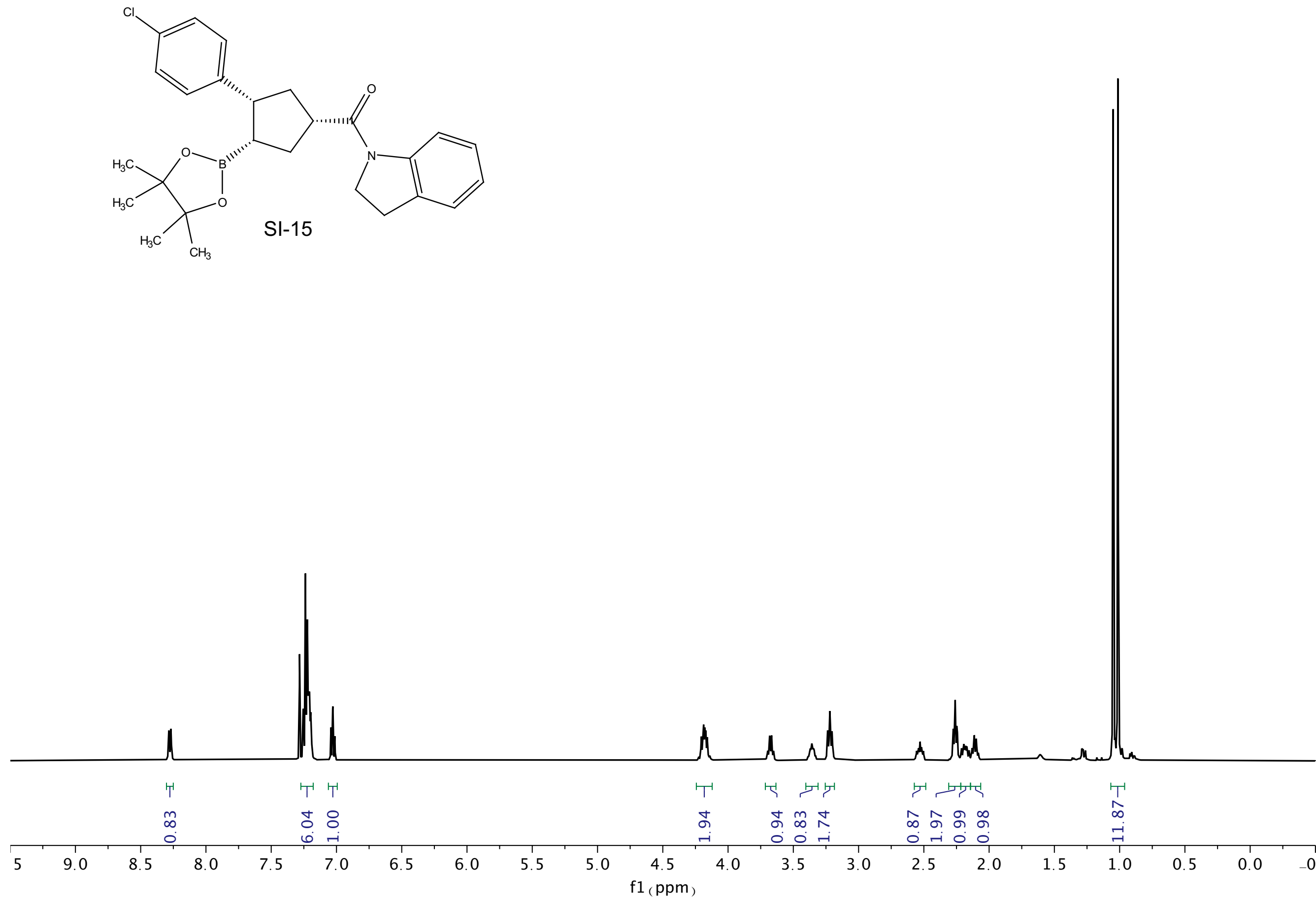

$\mathrm{CDCl} 3,126 \mathrm{MHz}$

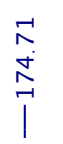
mom
守

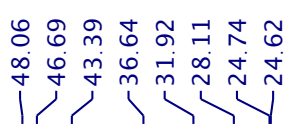

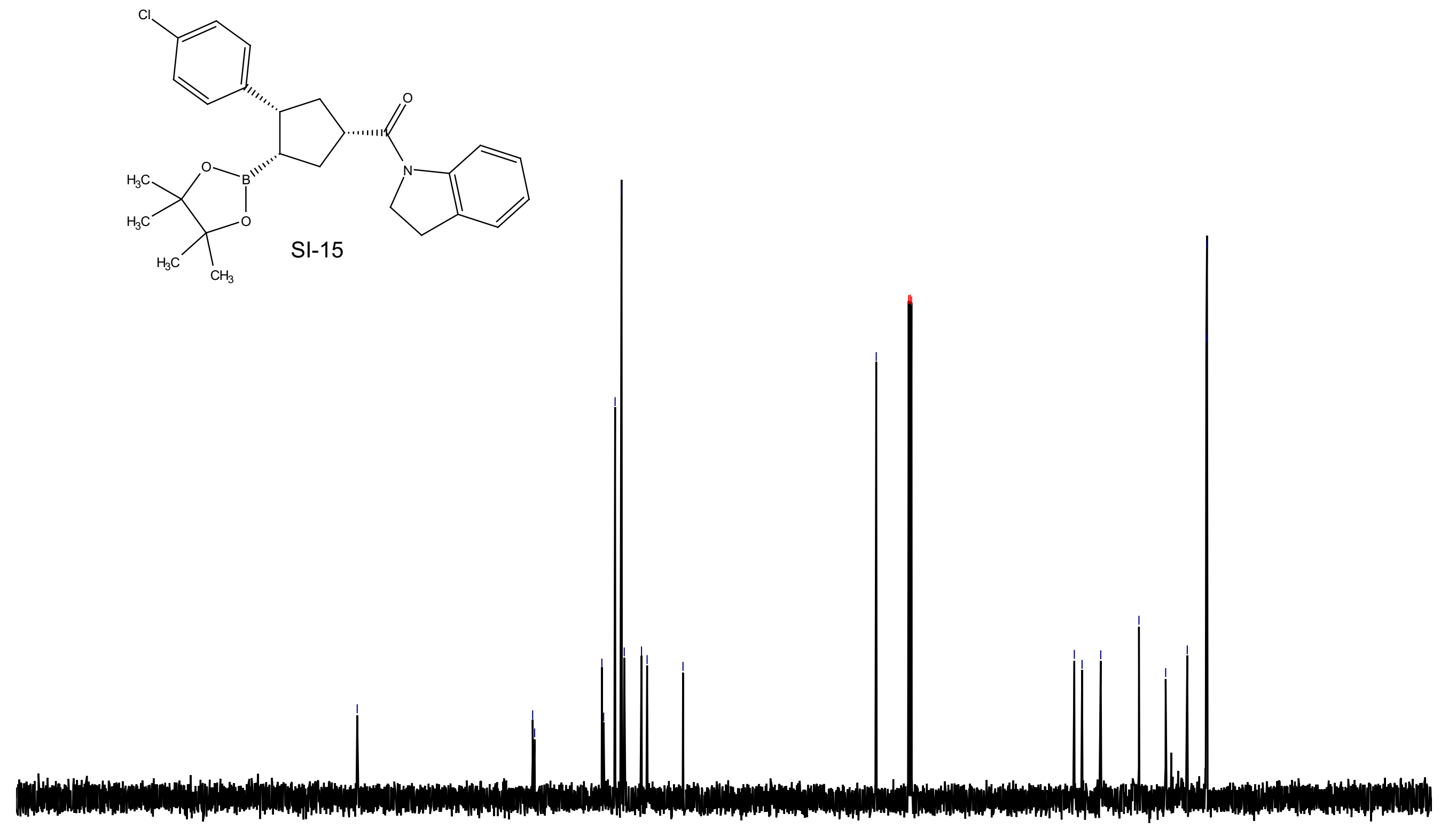

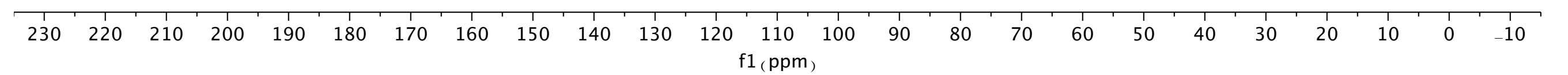


$\mathrm{CDCl} 3,500 \mathrm{MHz}$
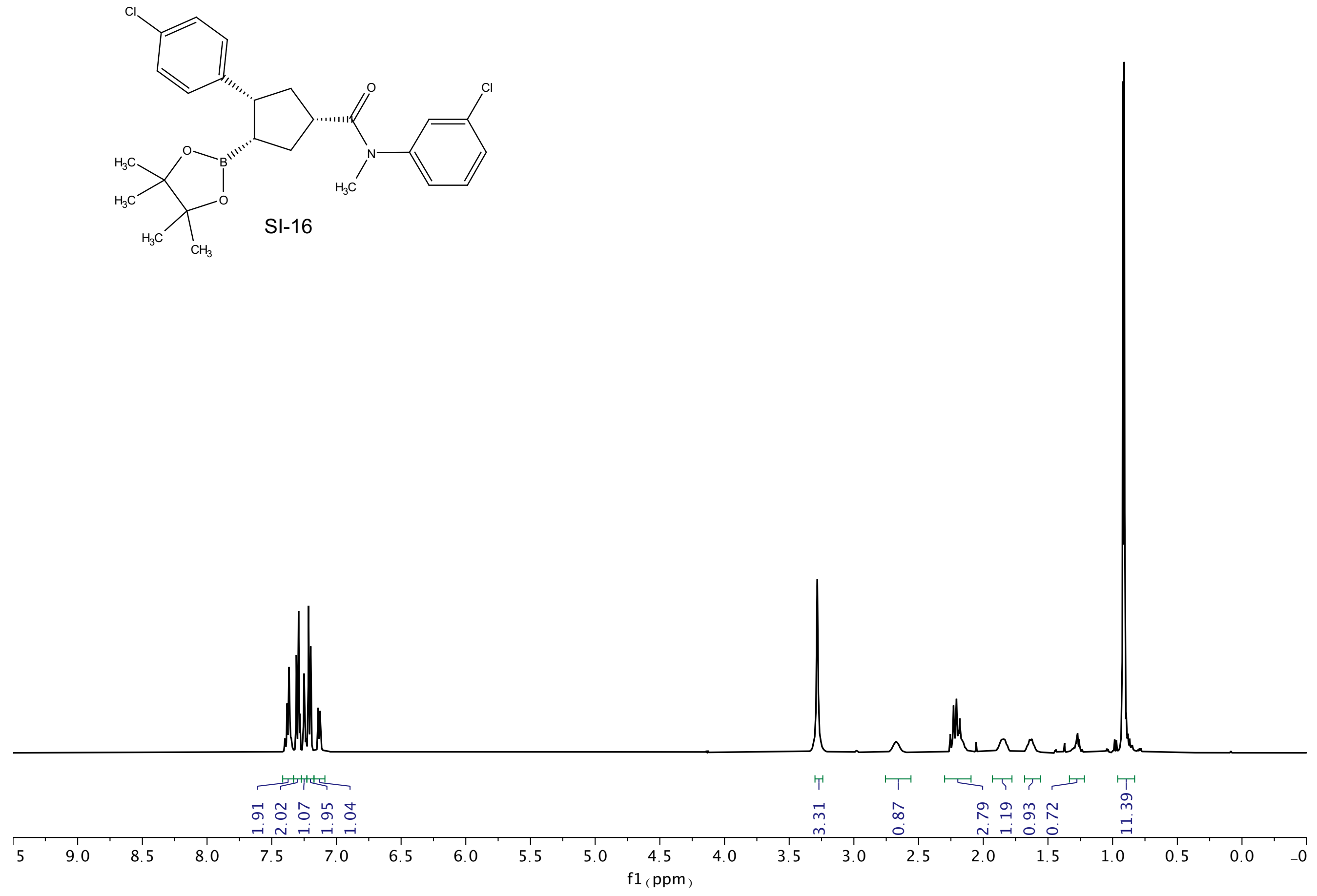


$\mathrm{CDCl}, 126 \mathrm{MHz}$
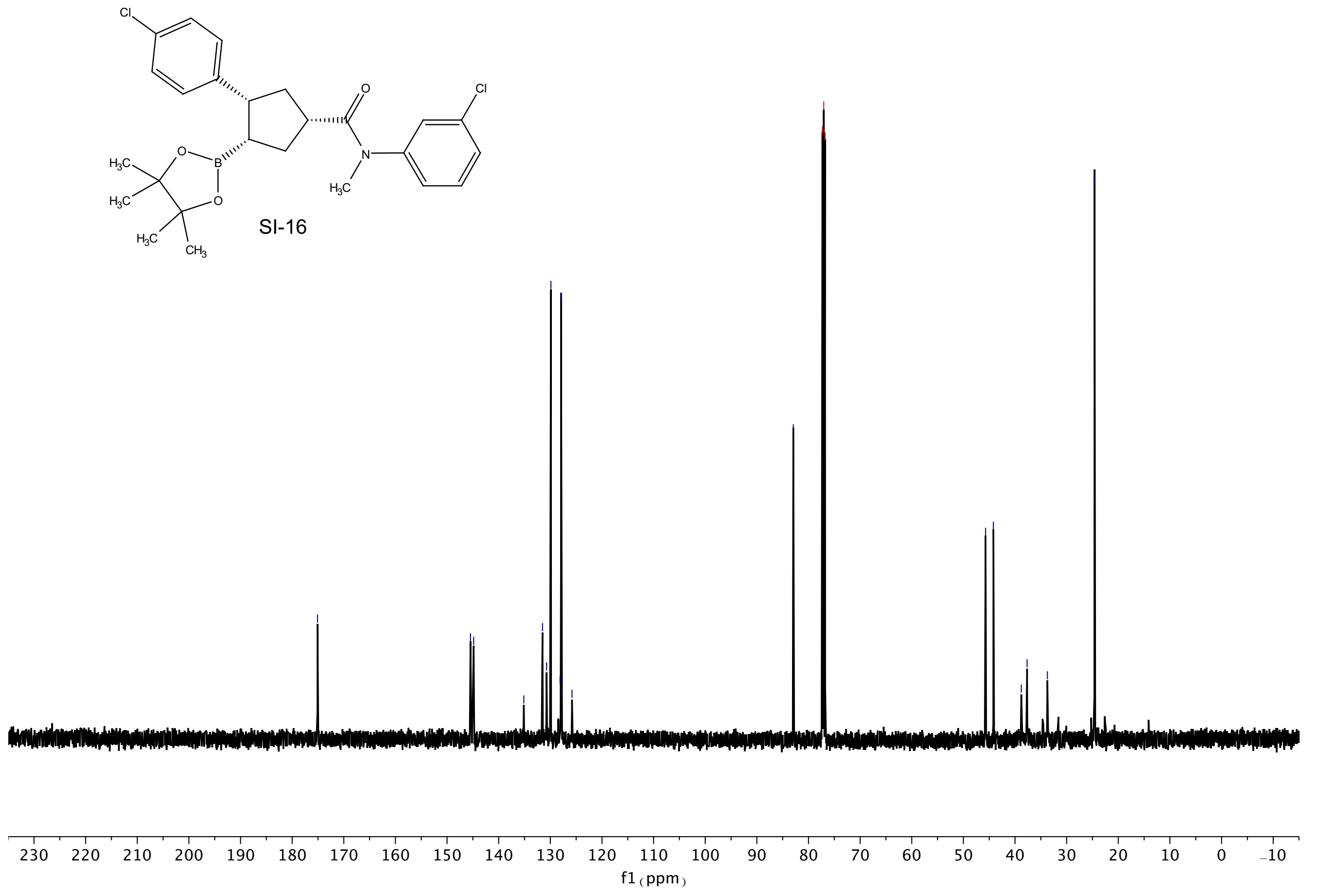

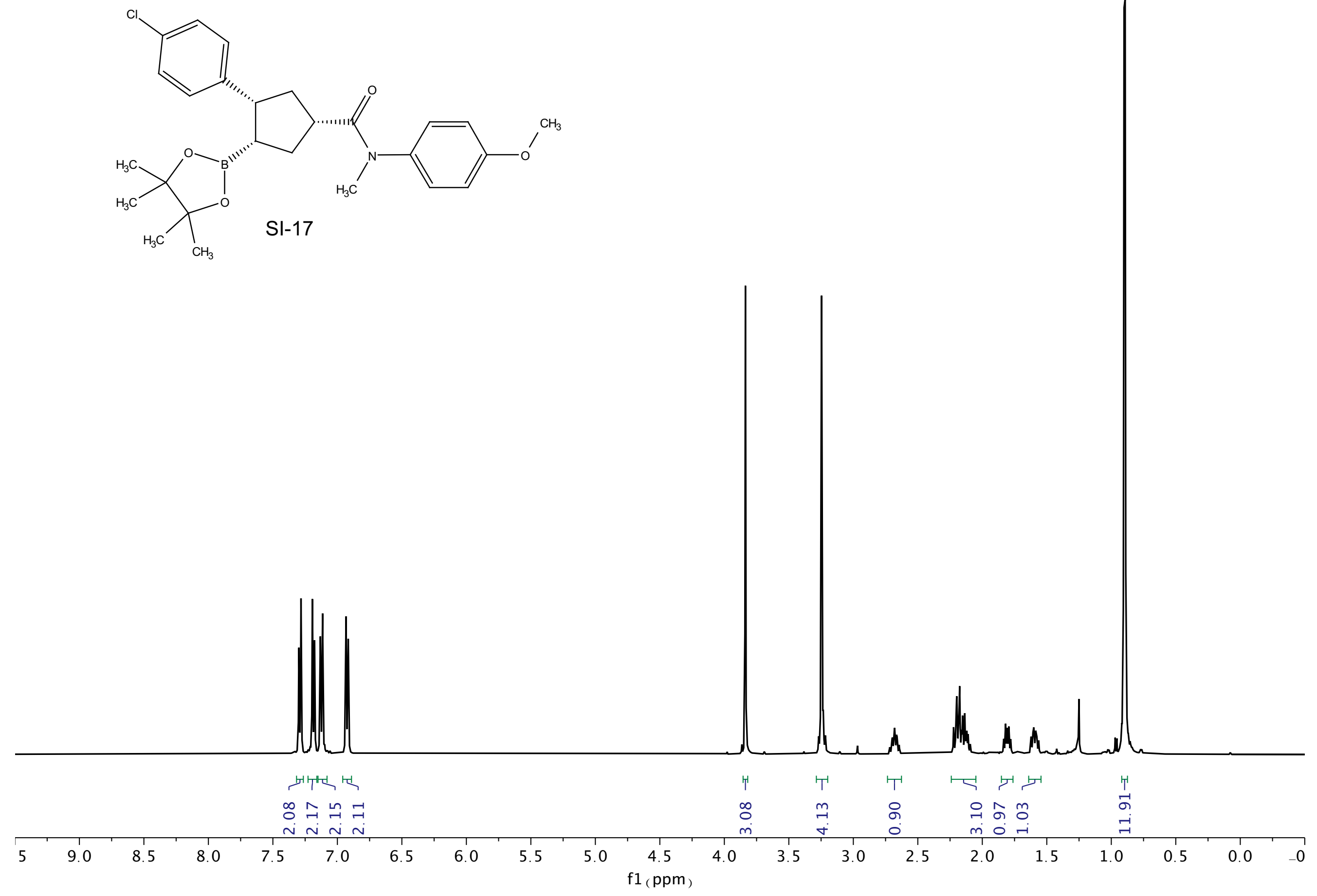


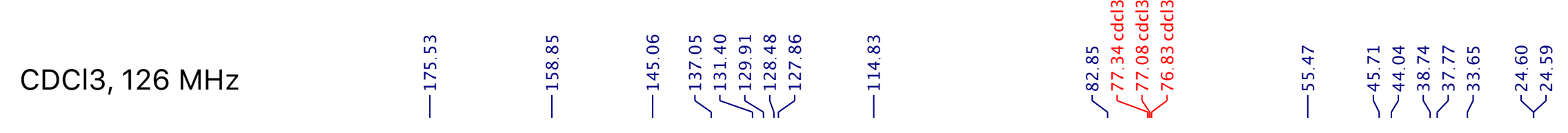
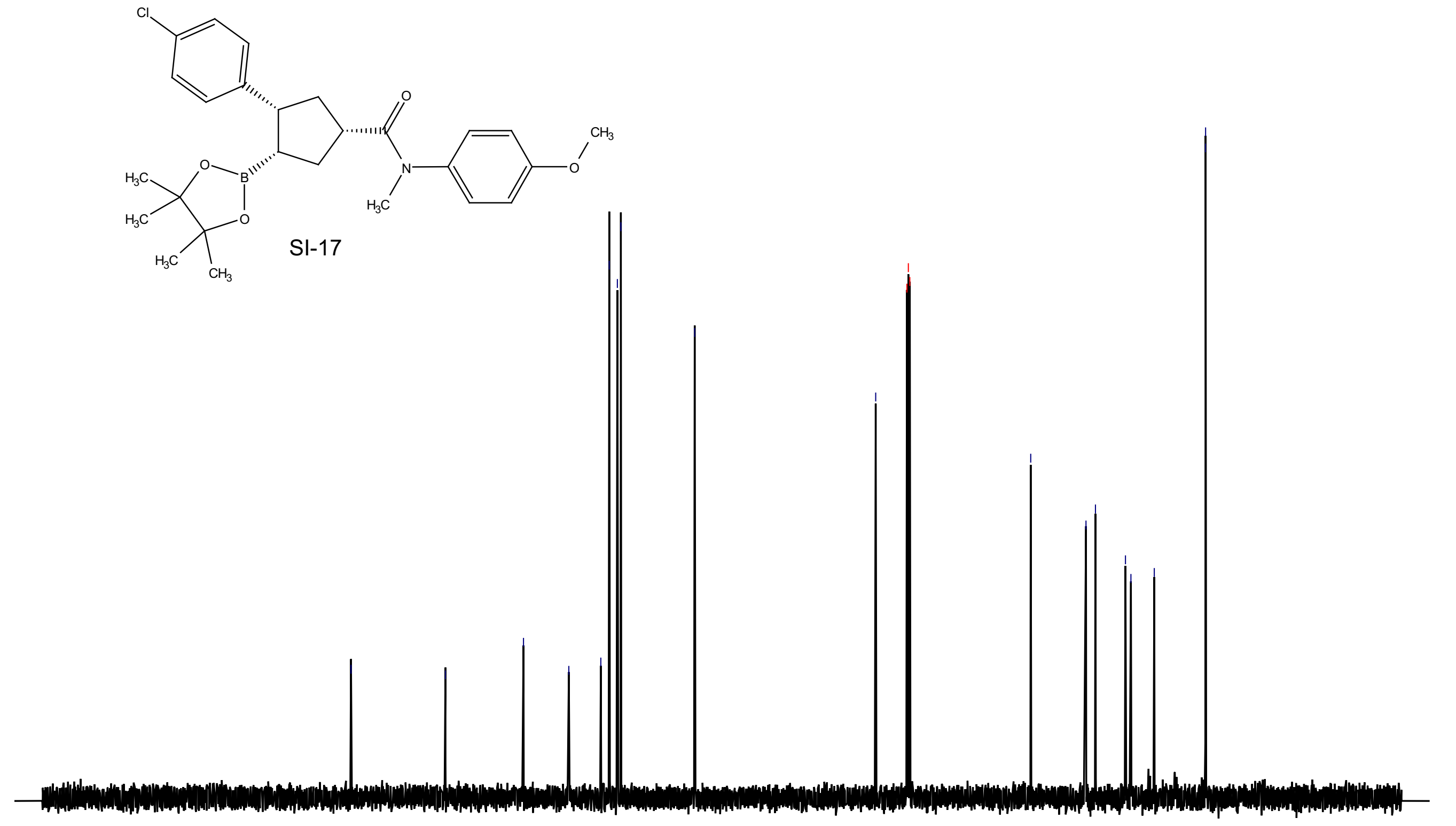
$\mathrm{CDCl} 3,500 \mathrm{MHz}$
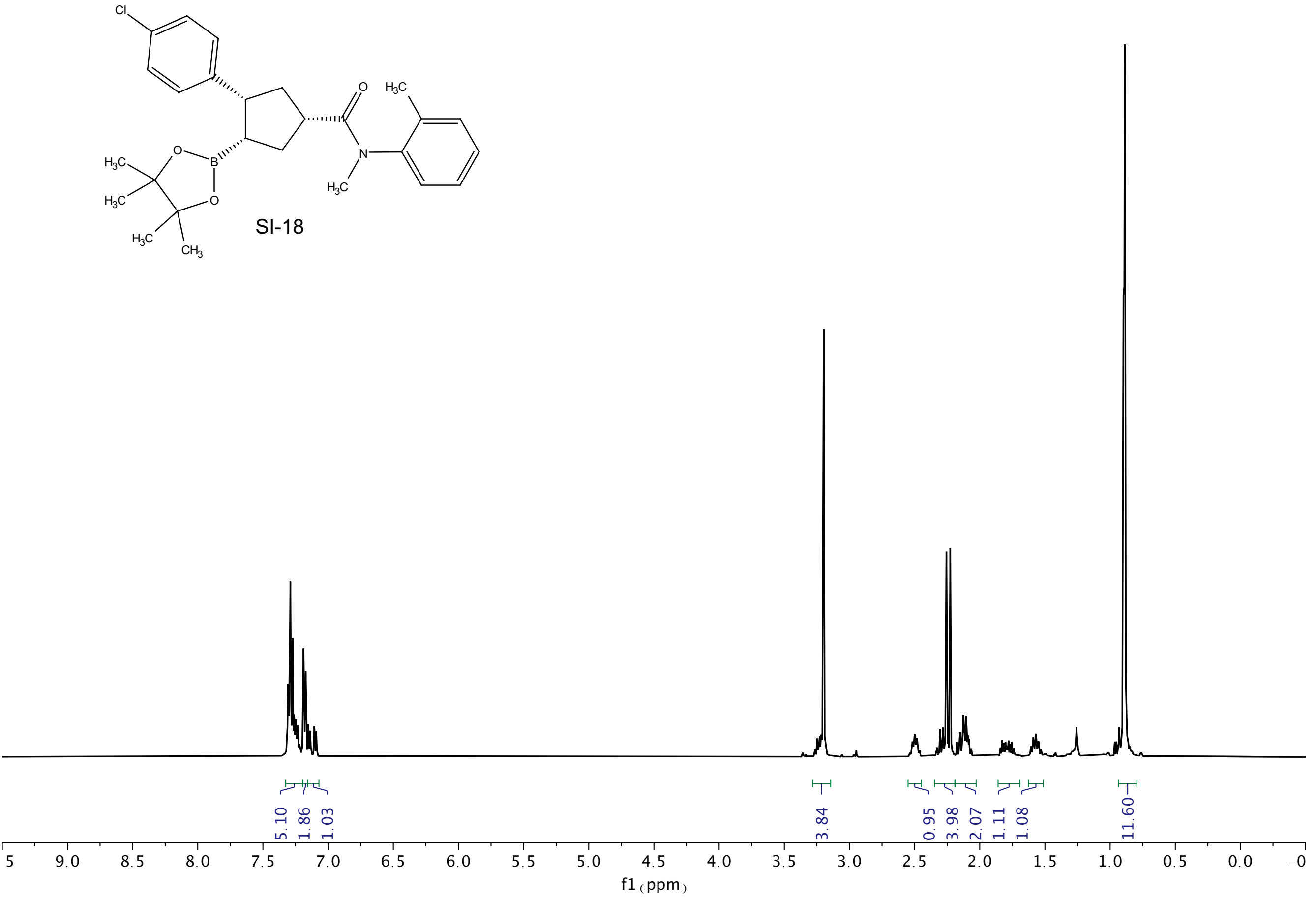

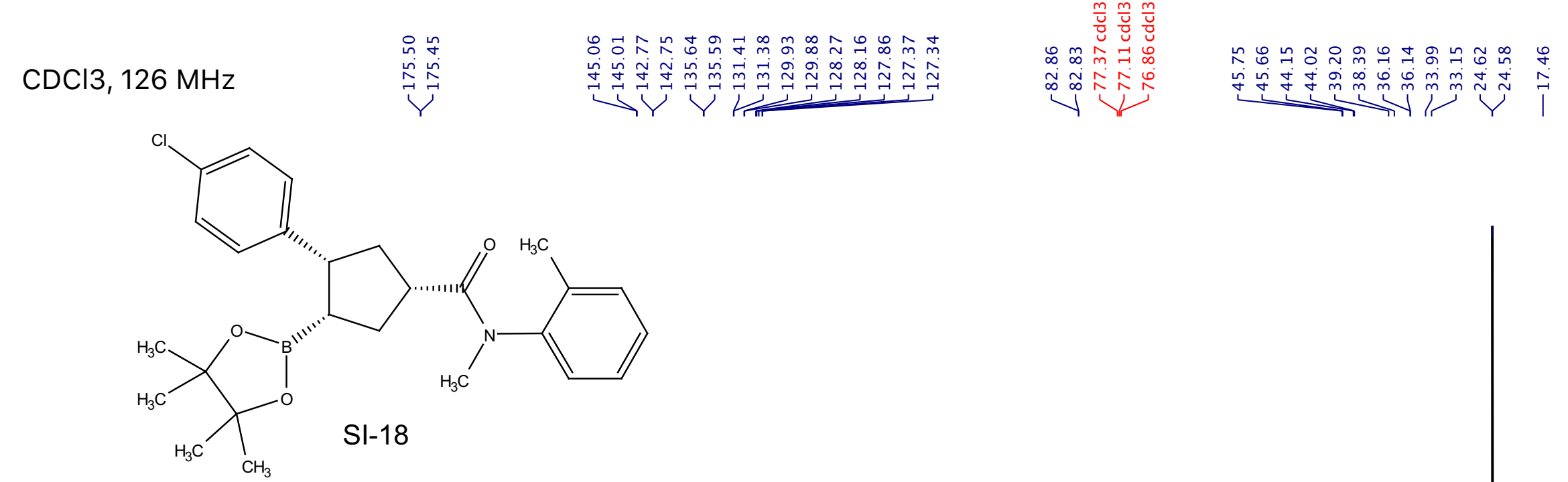
$\mathrm{CDCl} 3,500 \mathrm{MHz}$
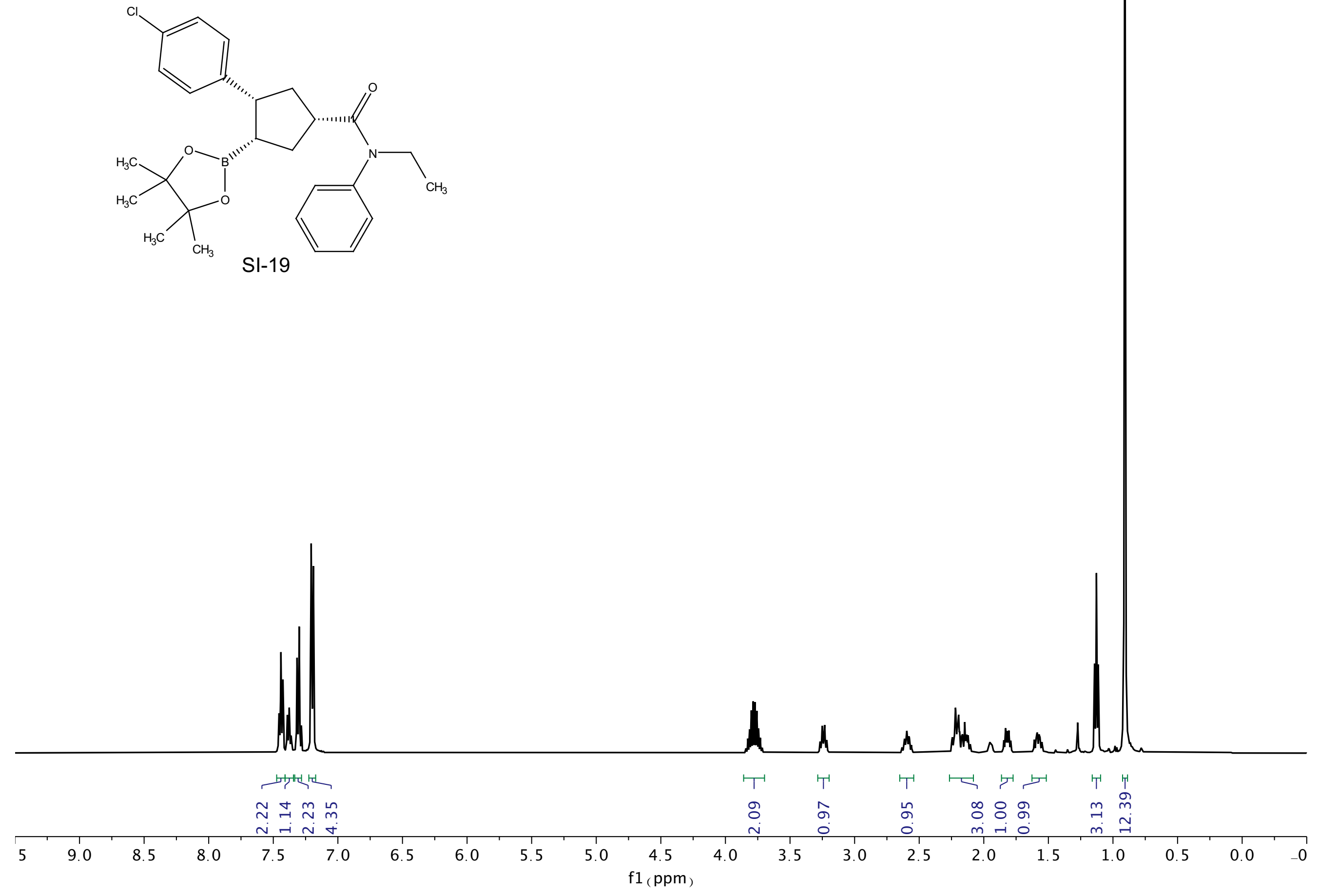


$\mathrm{CDCl}, 126 \mathrm{MHz}$
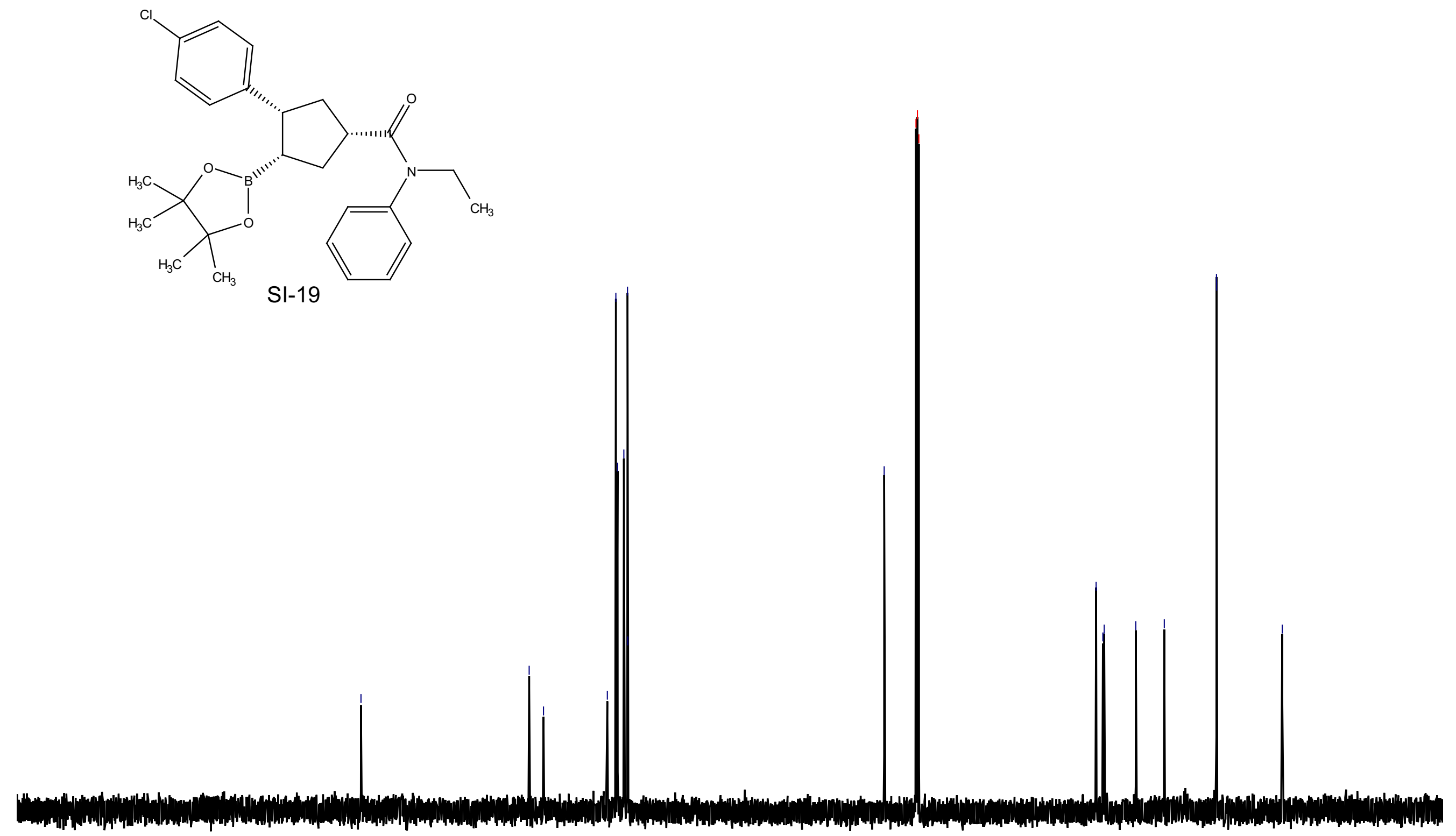

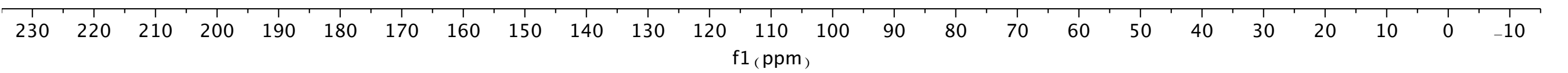


$\mathrm{CDCl} 3,500 \mathrm{MHz}$
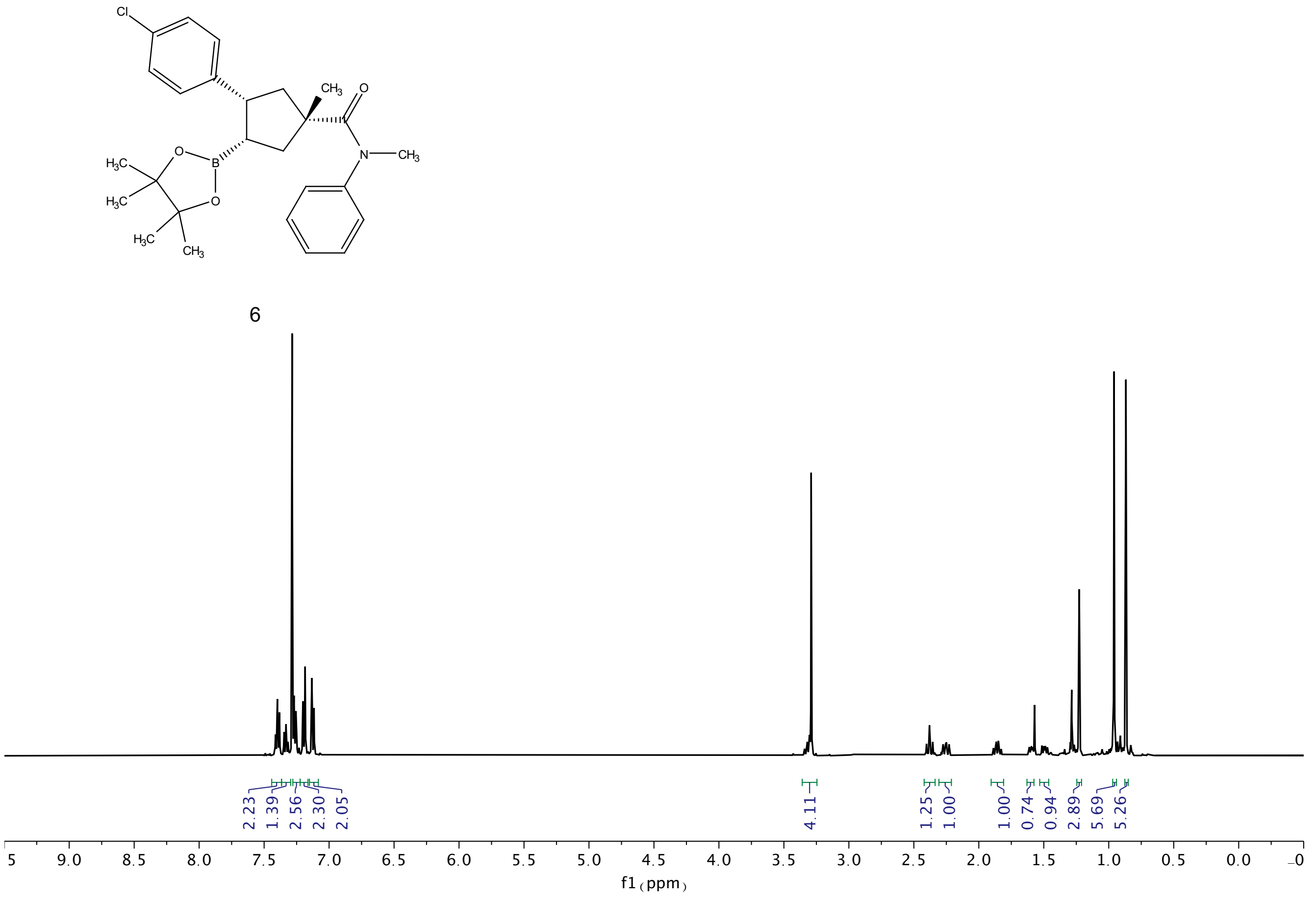

CDCl3, $126 \mathrm{MHz}$
$\stackrel{\substack{N \\ \stackrel{N}{N}}}{i}$

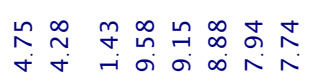

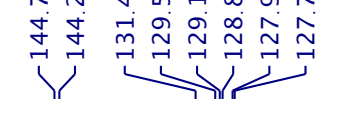

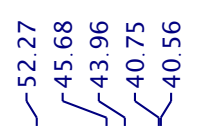

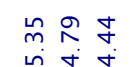

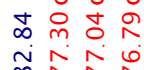
倠
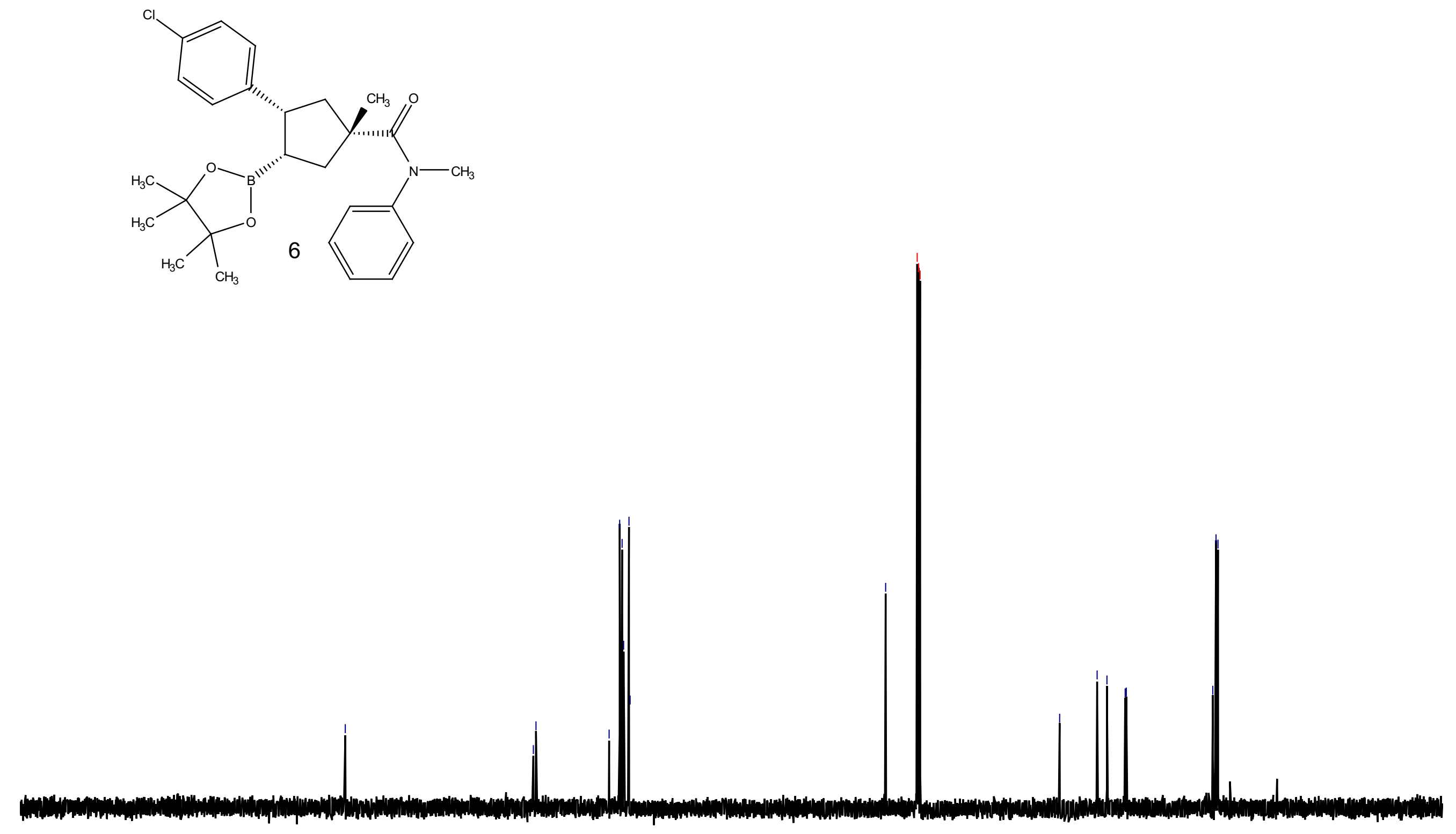

\begin{tabular}{|c|c|c|c|c|c|c|c|c|c|c|c|c|c|c|c|c|c|c|c|c|c|c|c|c|}
\hline 230 & 220 & 210 & 200 & 190 & 180 & 170 & 160 & 150 & 140 & 130 & 120 & 110 & 100 & 90 & 80 & 70 & 60 & 50 & 40 & 30 & 20 & 10 & 0 & -10 \\
\hline
\end{tabular}




\section{$\mathrm{CDCl} 3,400 \mathrm{MHz}$}

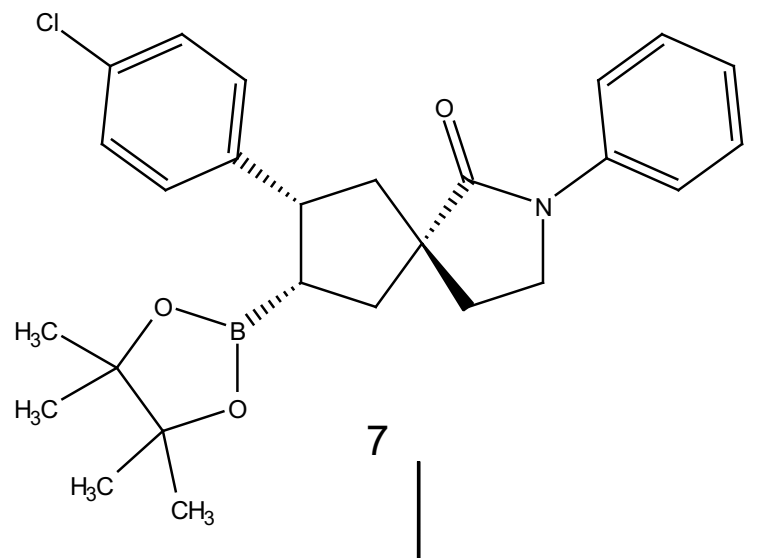

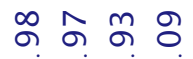

-i m ri ri

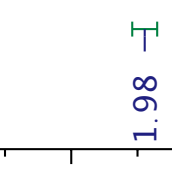

T

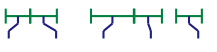

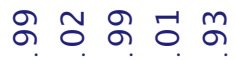

ดิ ลิ

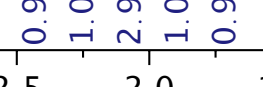




$$
\mathrm{CDCl} 3,101 \mathrm{MHz}
$$

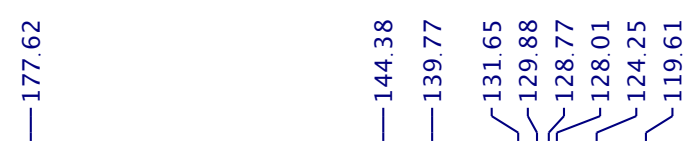

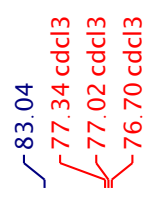

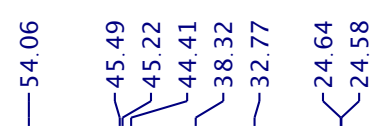<smiles>CC1(C)OB([C@@H]2C[C@]3(CCN(c4ccccc4)C3=O)C[C@H]2c2ccc(Cl)cc2)OC1(C)C</smiles>

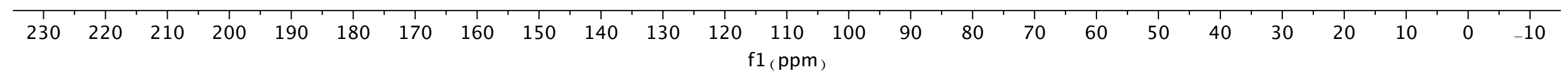




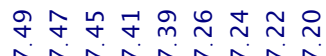

$\mathrm{CDCl} 3,400 \mathrm{MHz}$

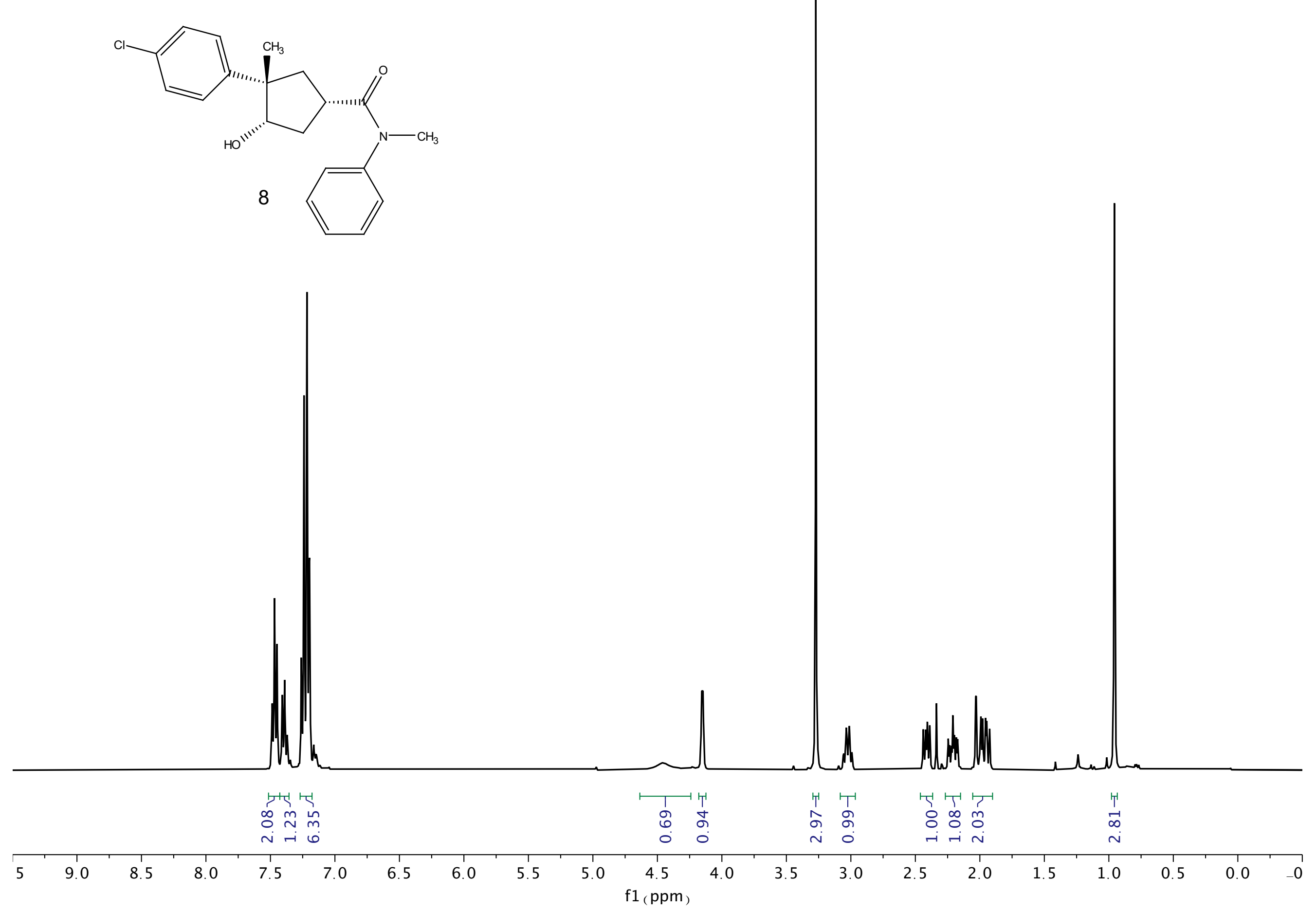

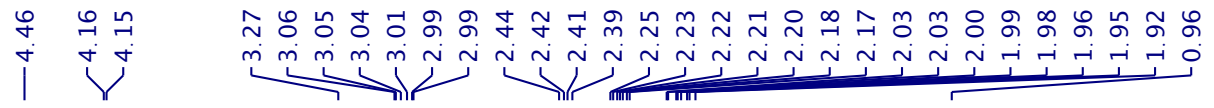




$\mathrm{CDCl}, 126 \mathrm{MHz}$ إl
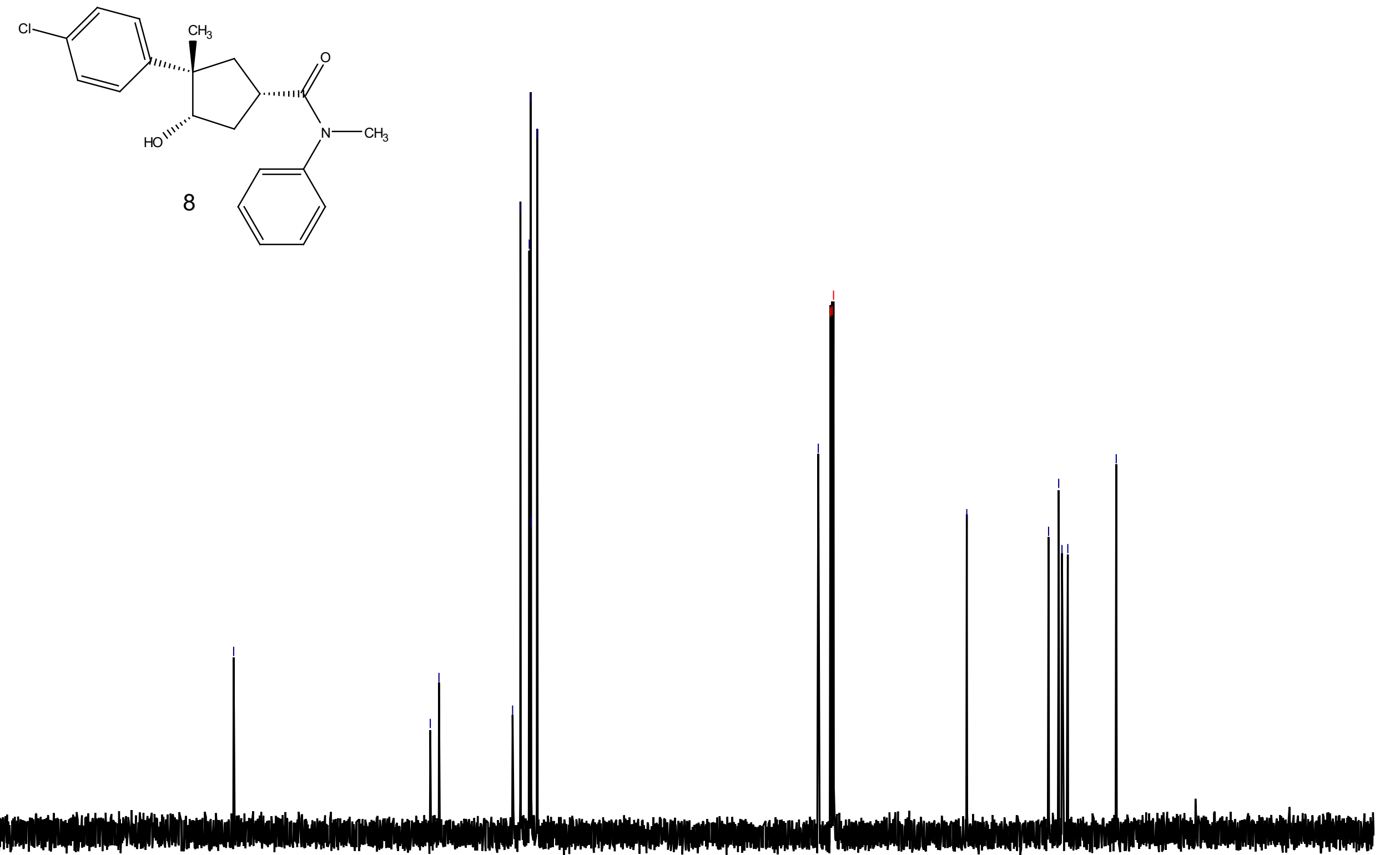

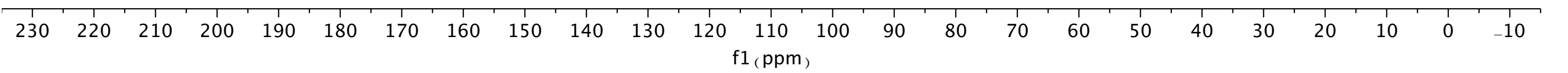



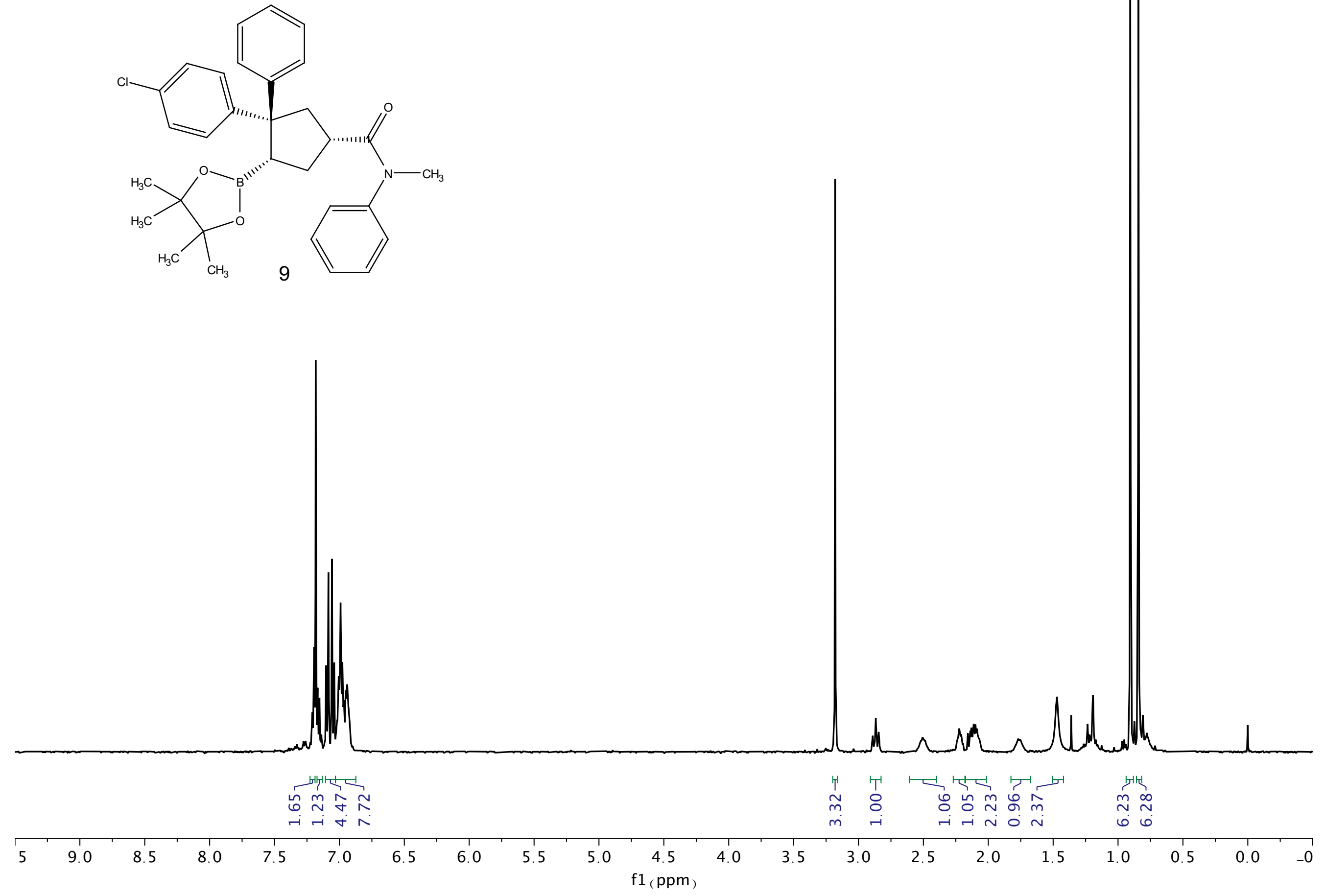


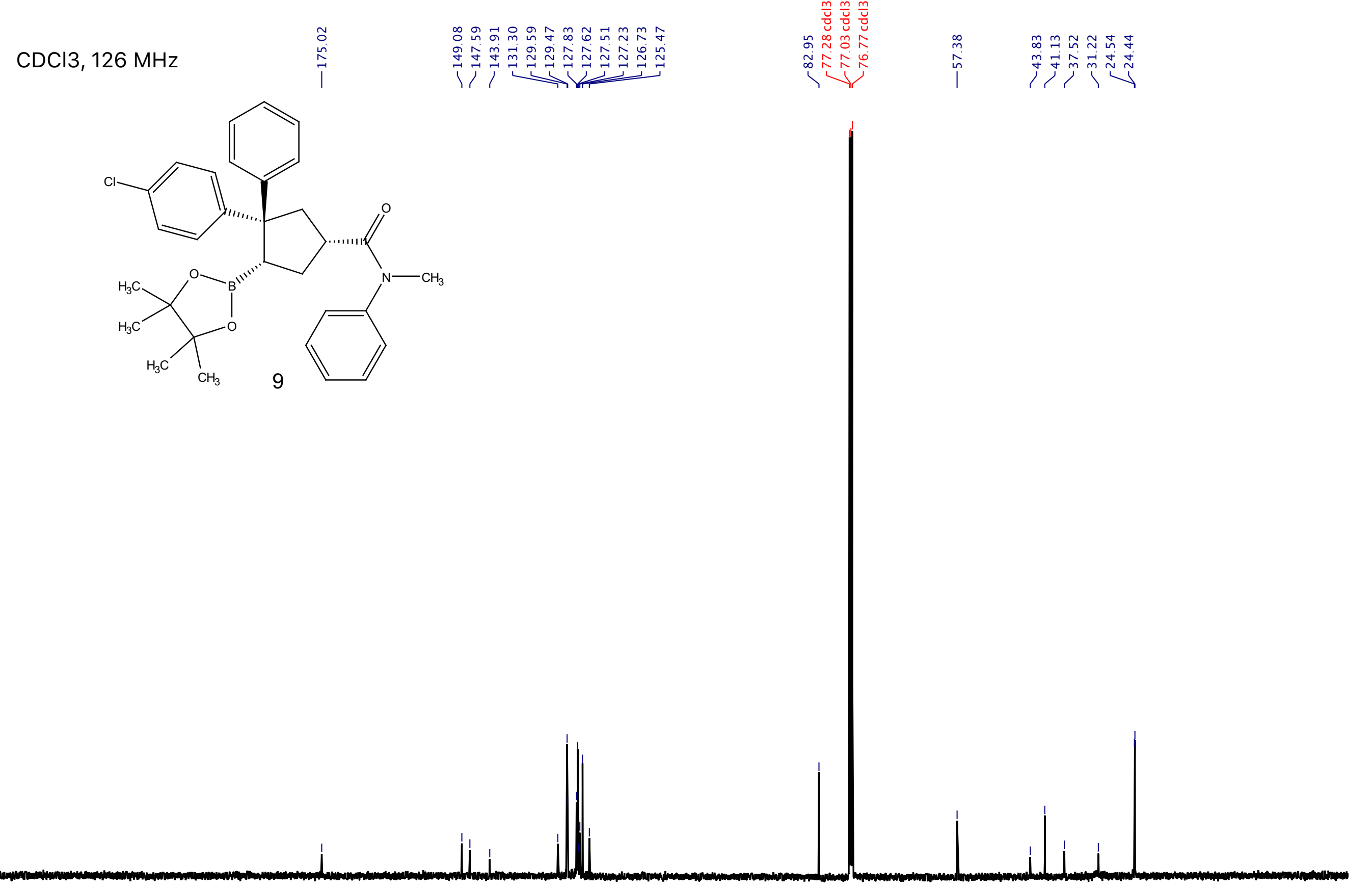

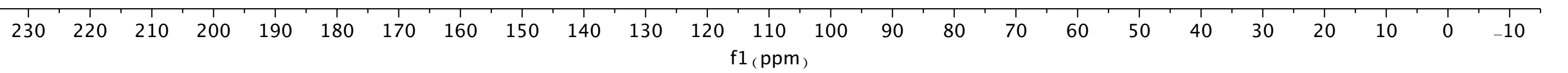


$\mathrm{CDCl} 3,400 \mathrm{MHz}$
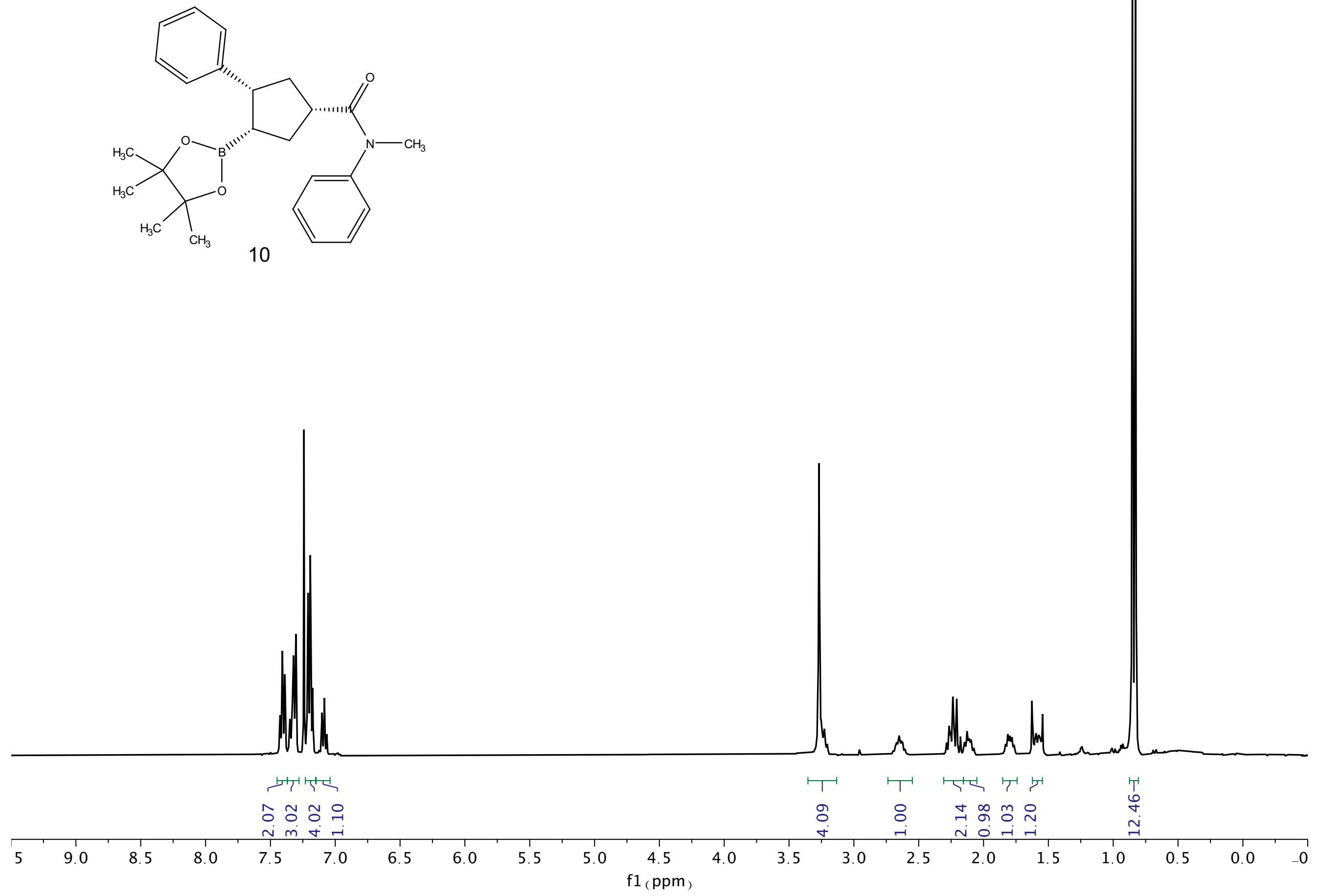


$\mathrm{CDCl}, 101 \mathrm{MHz}$

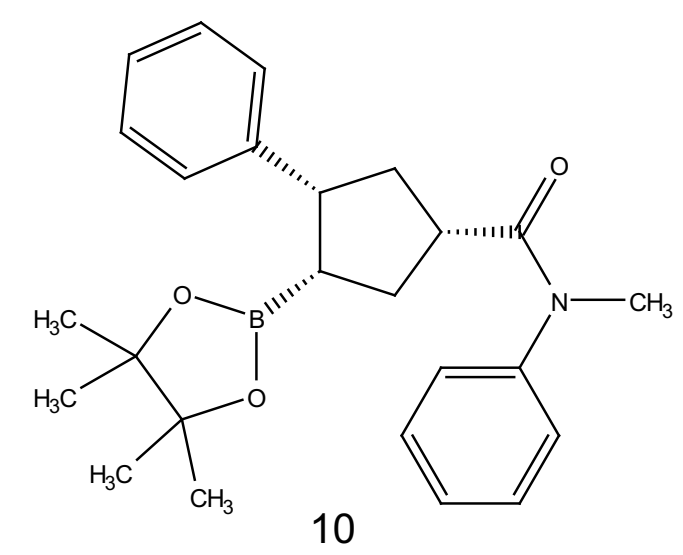




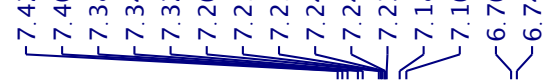

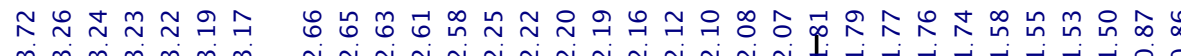

CDCl3, $400 \mathrm{MHz}$
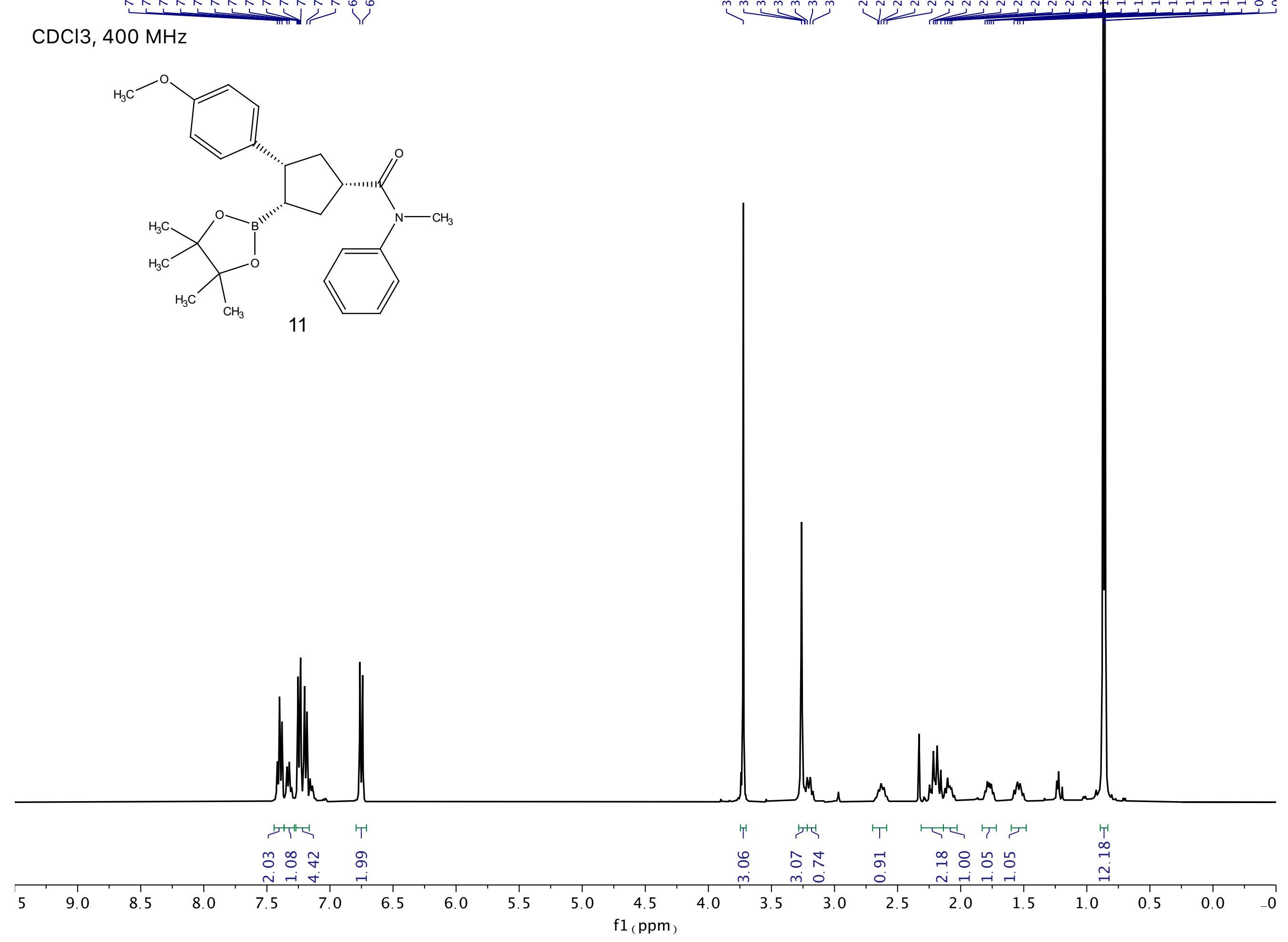


$\mathrm{CDCl}, 101 \mathrm{MHz}$<smiles>COc1ccc([C@H]2C[C@H](C(=O)N(C)c3ccccc3)C[C@H]2C2OC(C)(C)C(C)(C)O2)cc1</smiles>

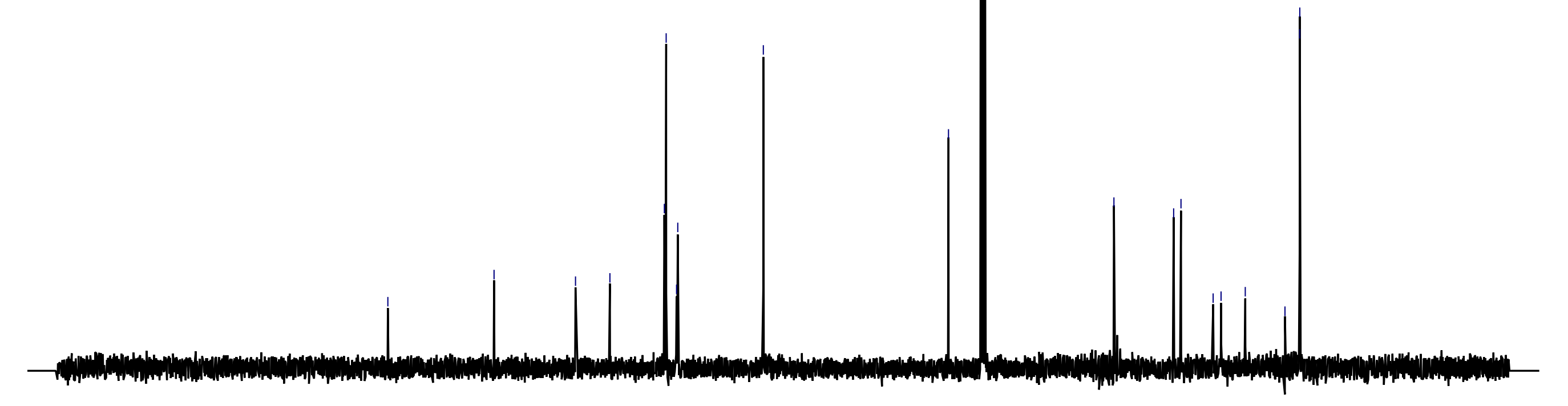

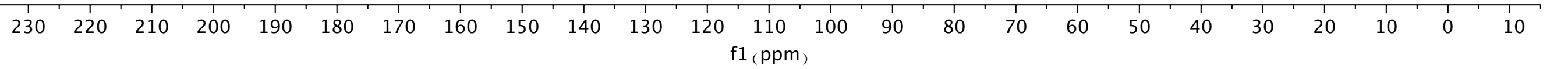



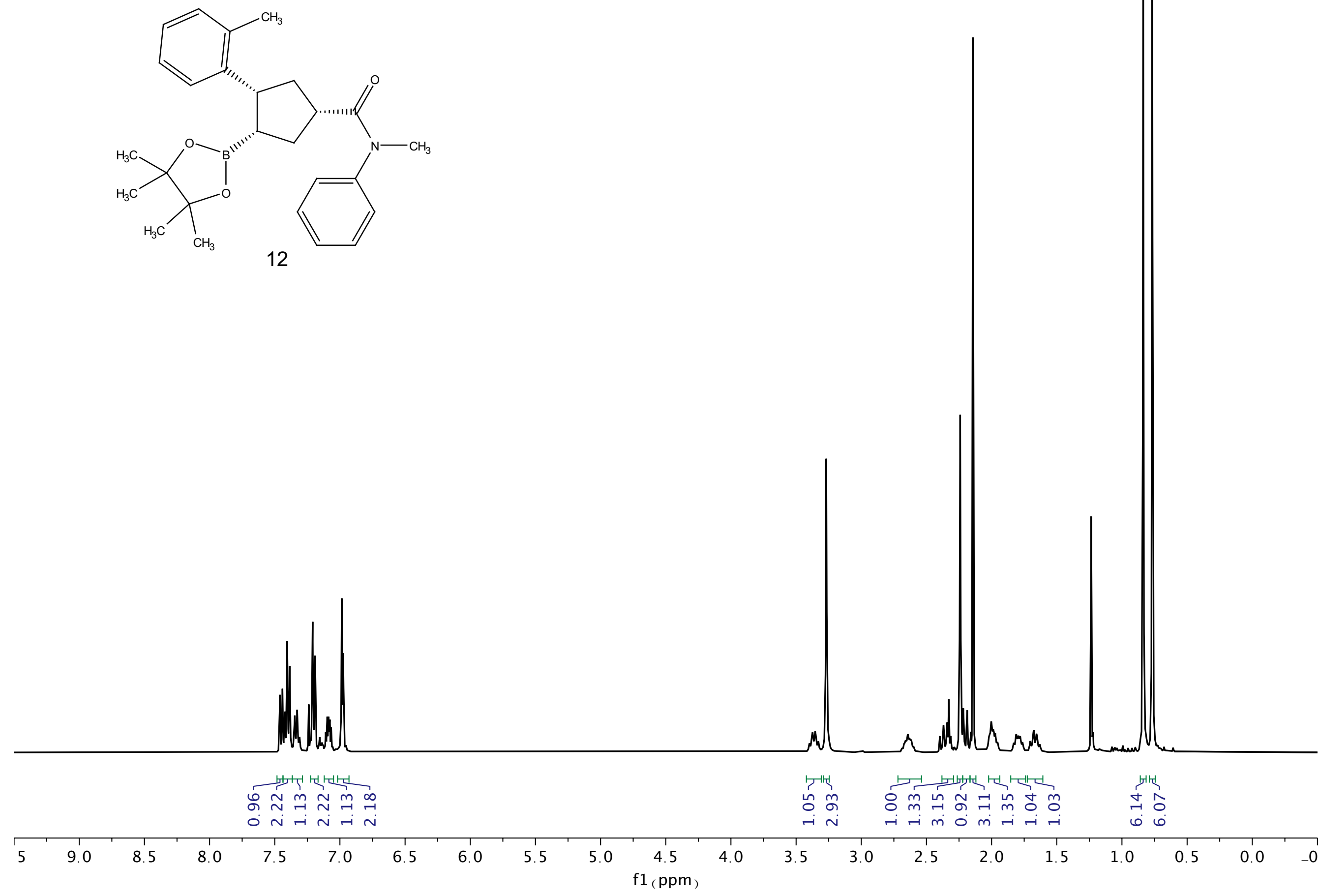


\section{$\mathrm{CDCl} 3,126 \mathrm{MHz}$}

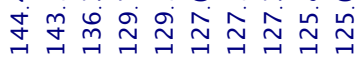

पर पर

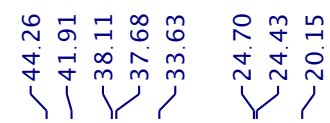<smiles>Cc1ccccc1[C@@H]1C[C@H](C(=O)N(C)c2ccccc2)C[C@H]1B1OC(C)(C)C(C)(C)O1</smiles>

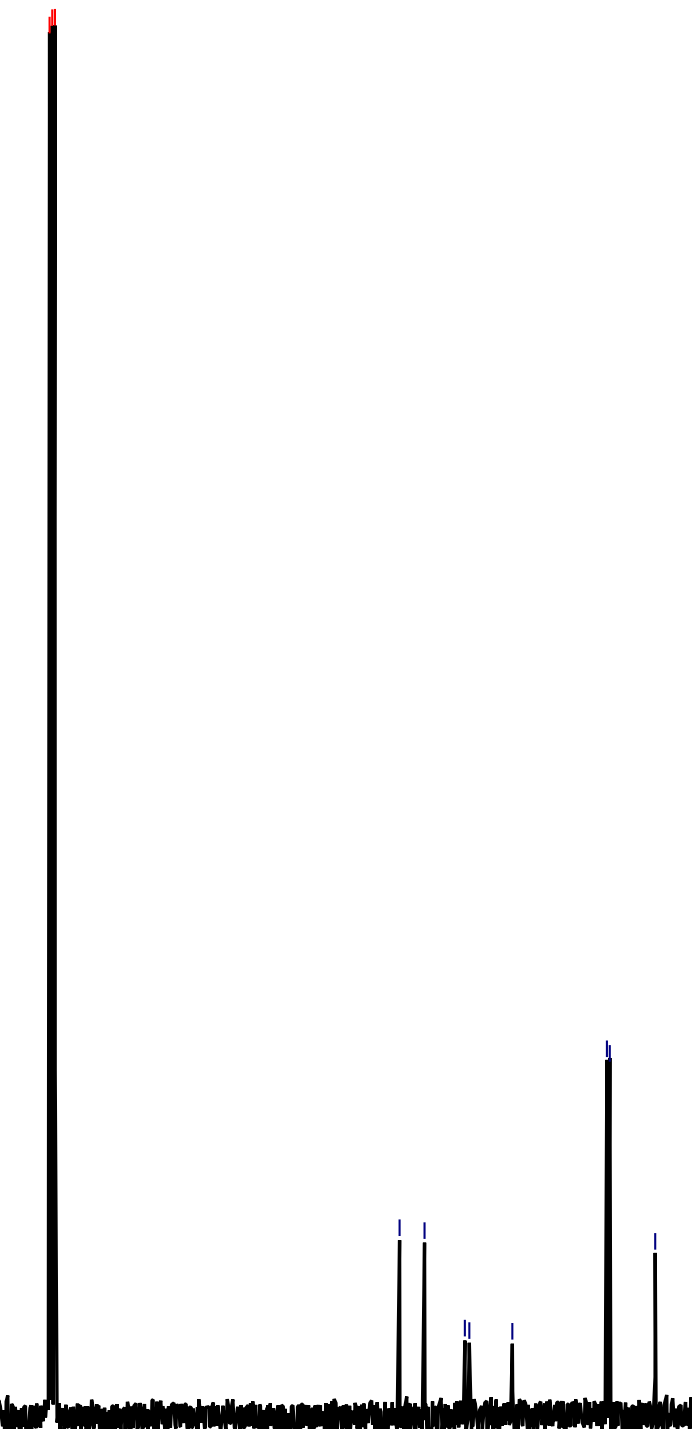


$\mathrm{CDCl} 3,400 \mathrm{MHz}$
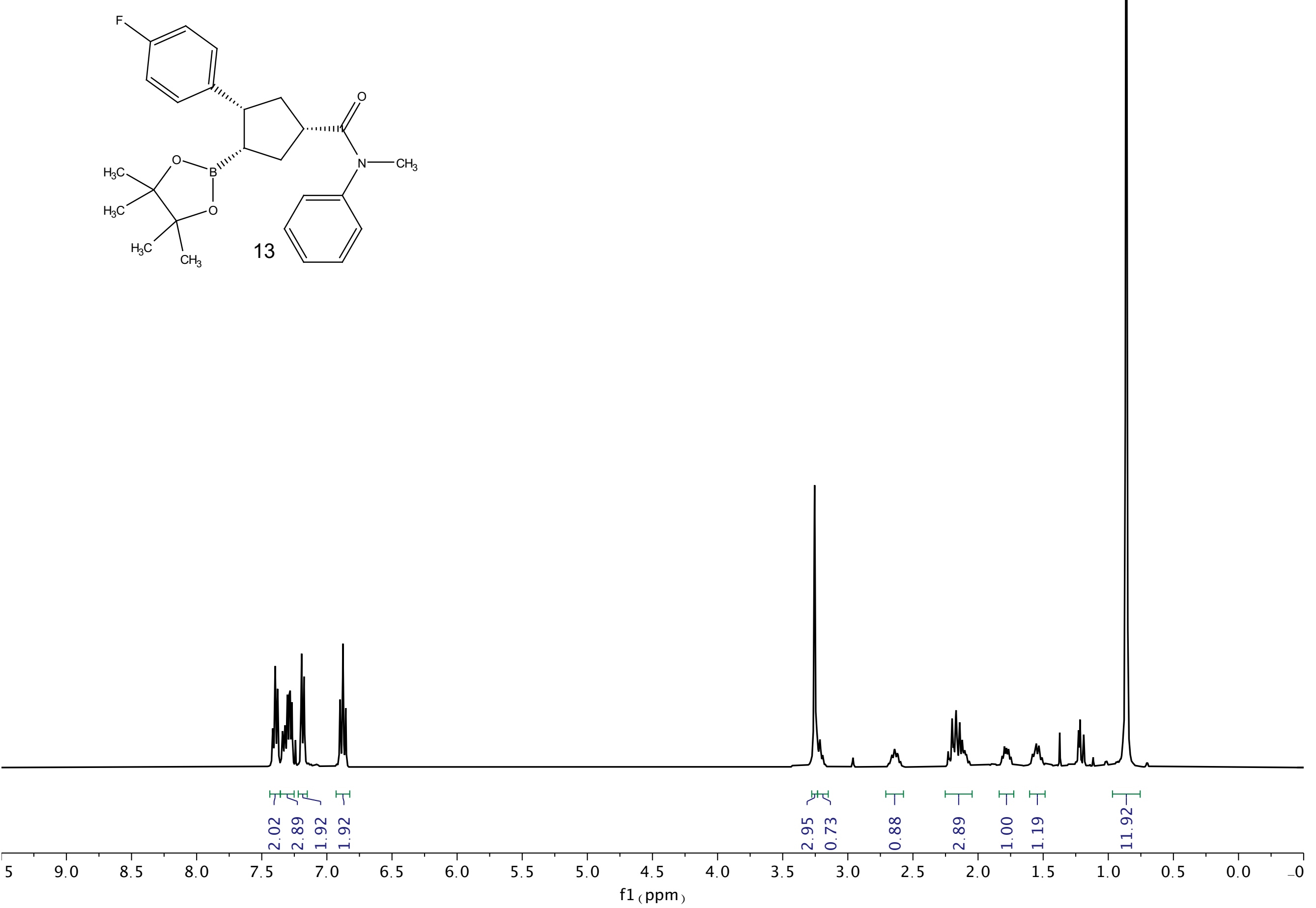


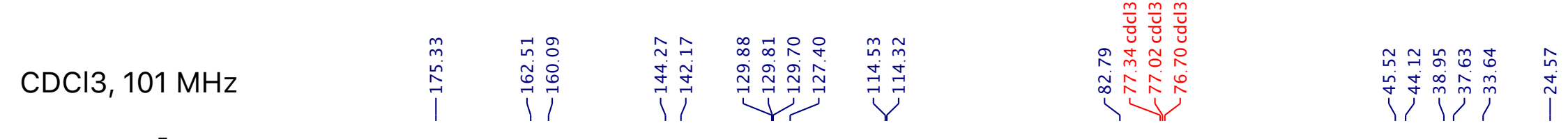
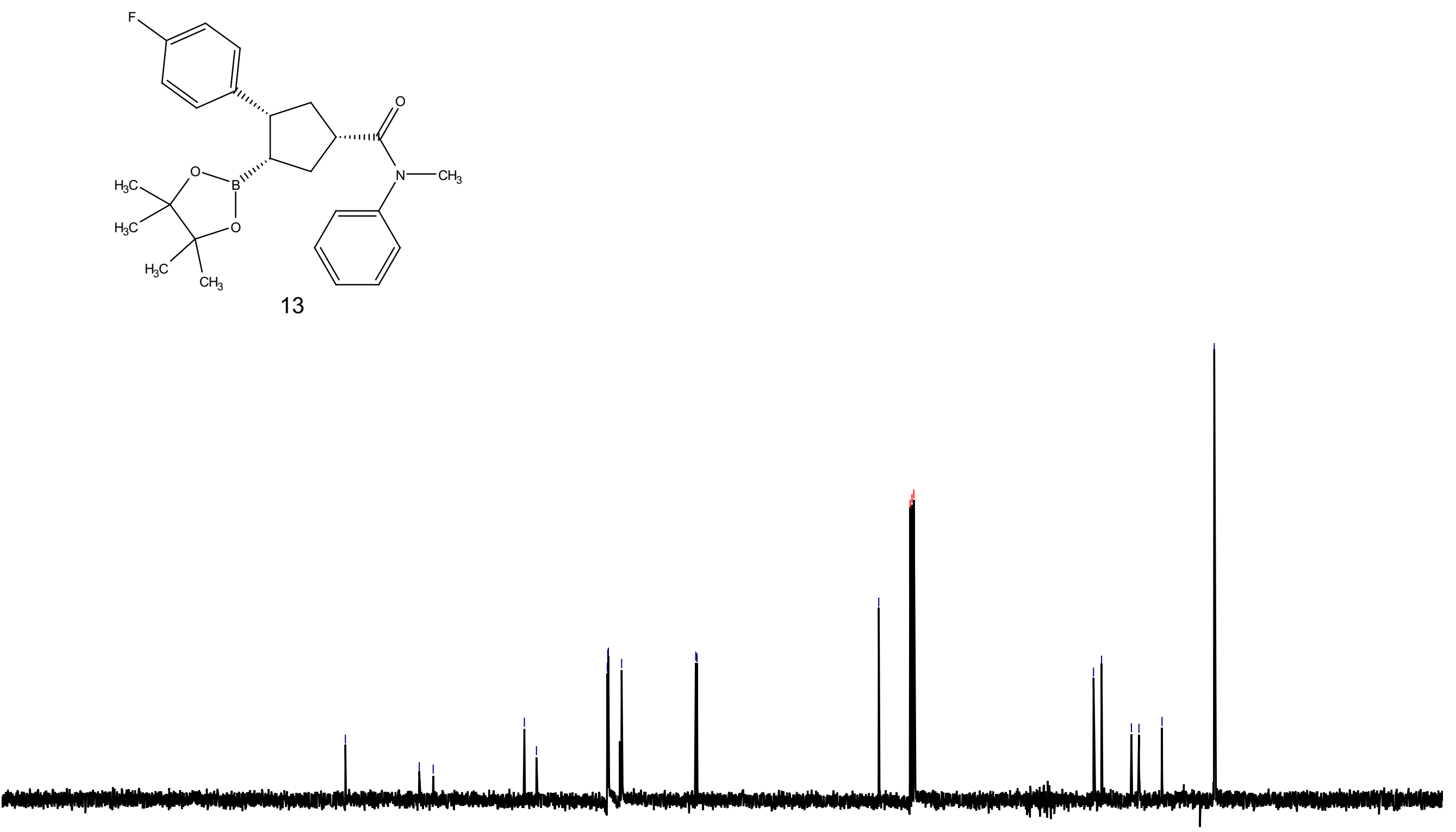

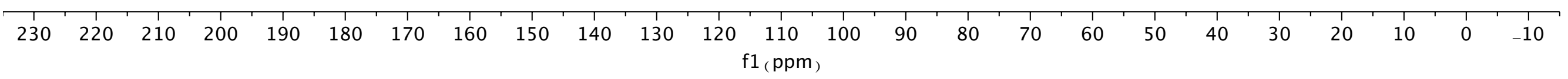


$\mathrm{CDCl} 3,376 \mathrm{MHz}$
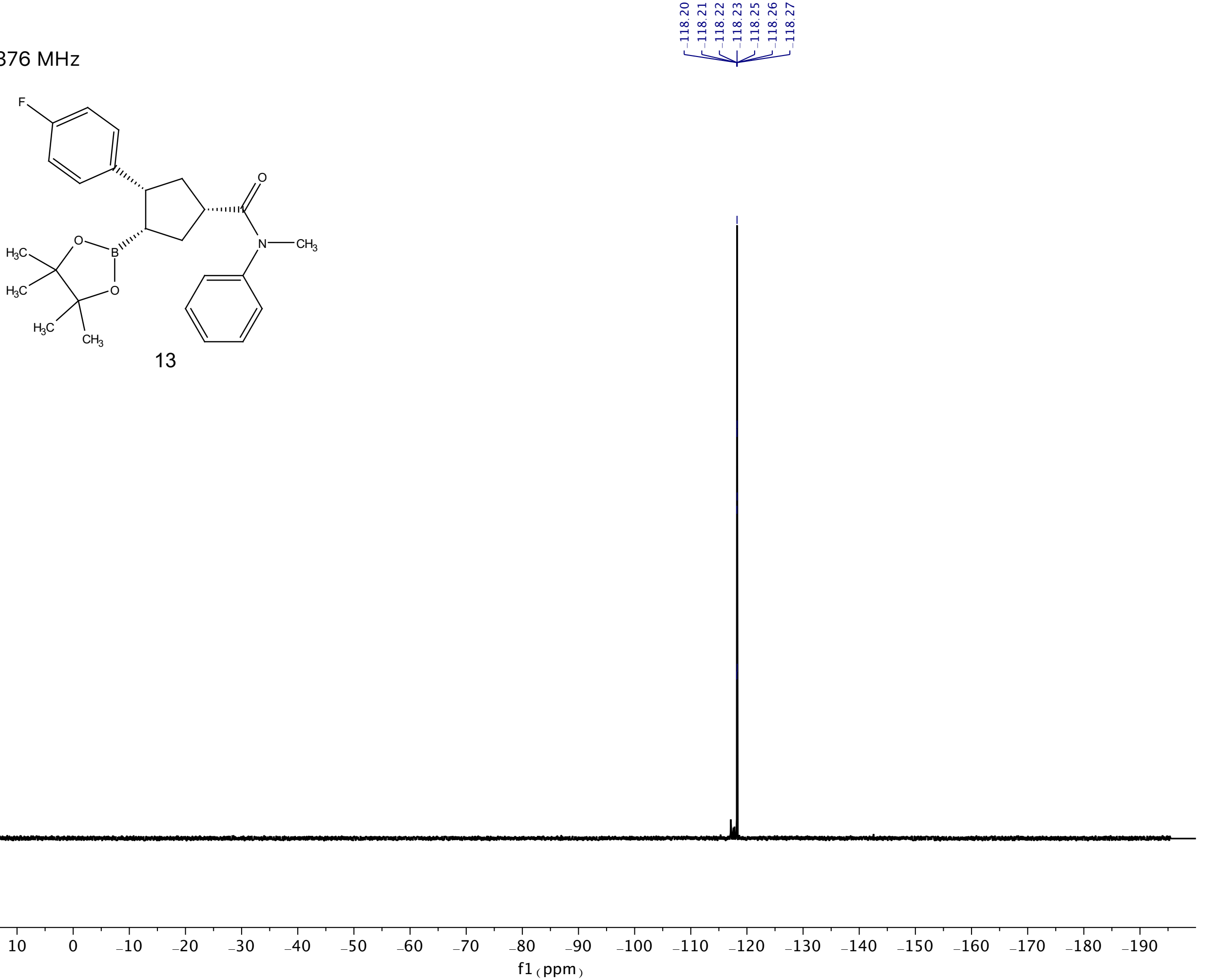


\section{$\mathrm{CDCl} 3,600 \mathrm{MHz}$}
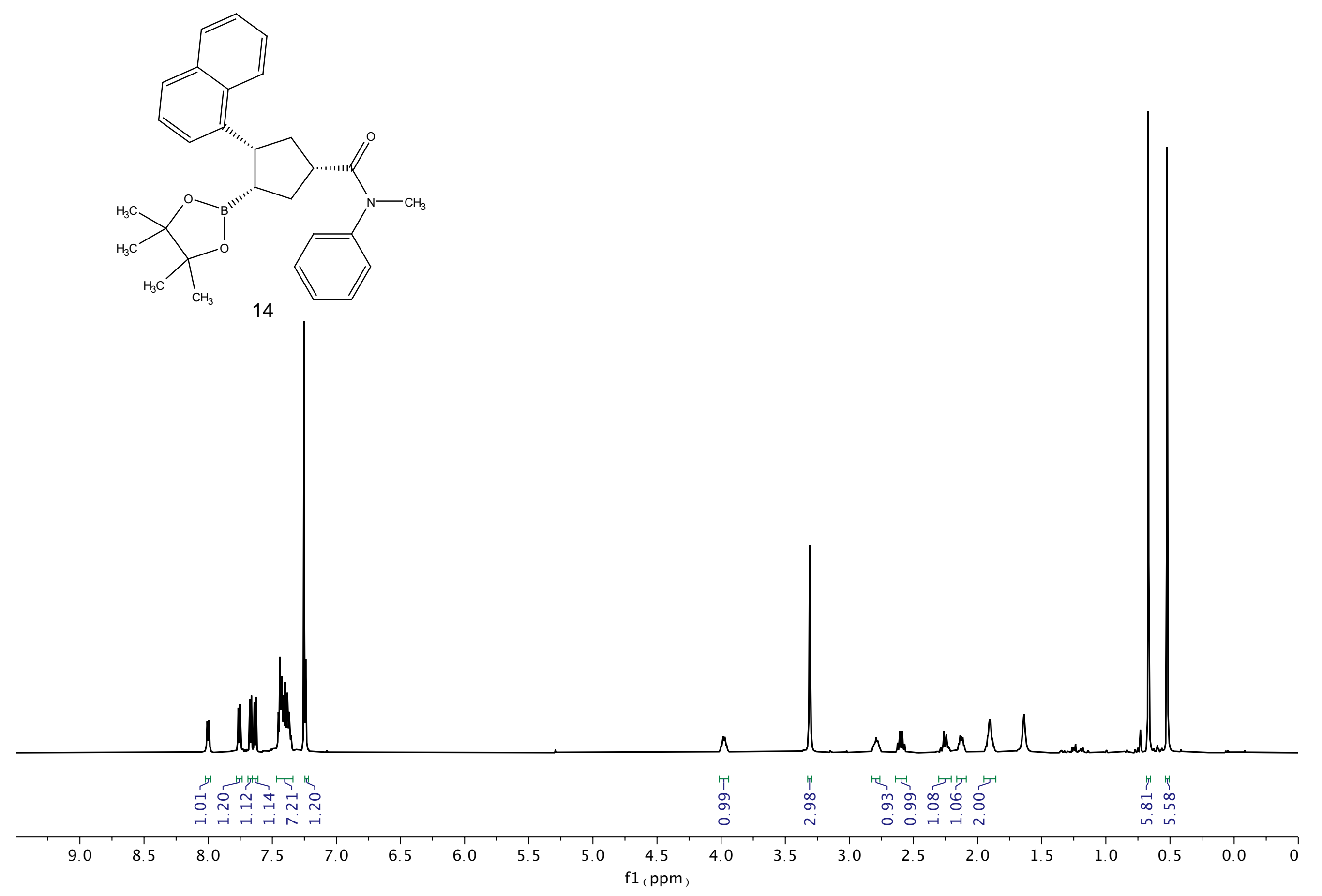

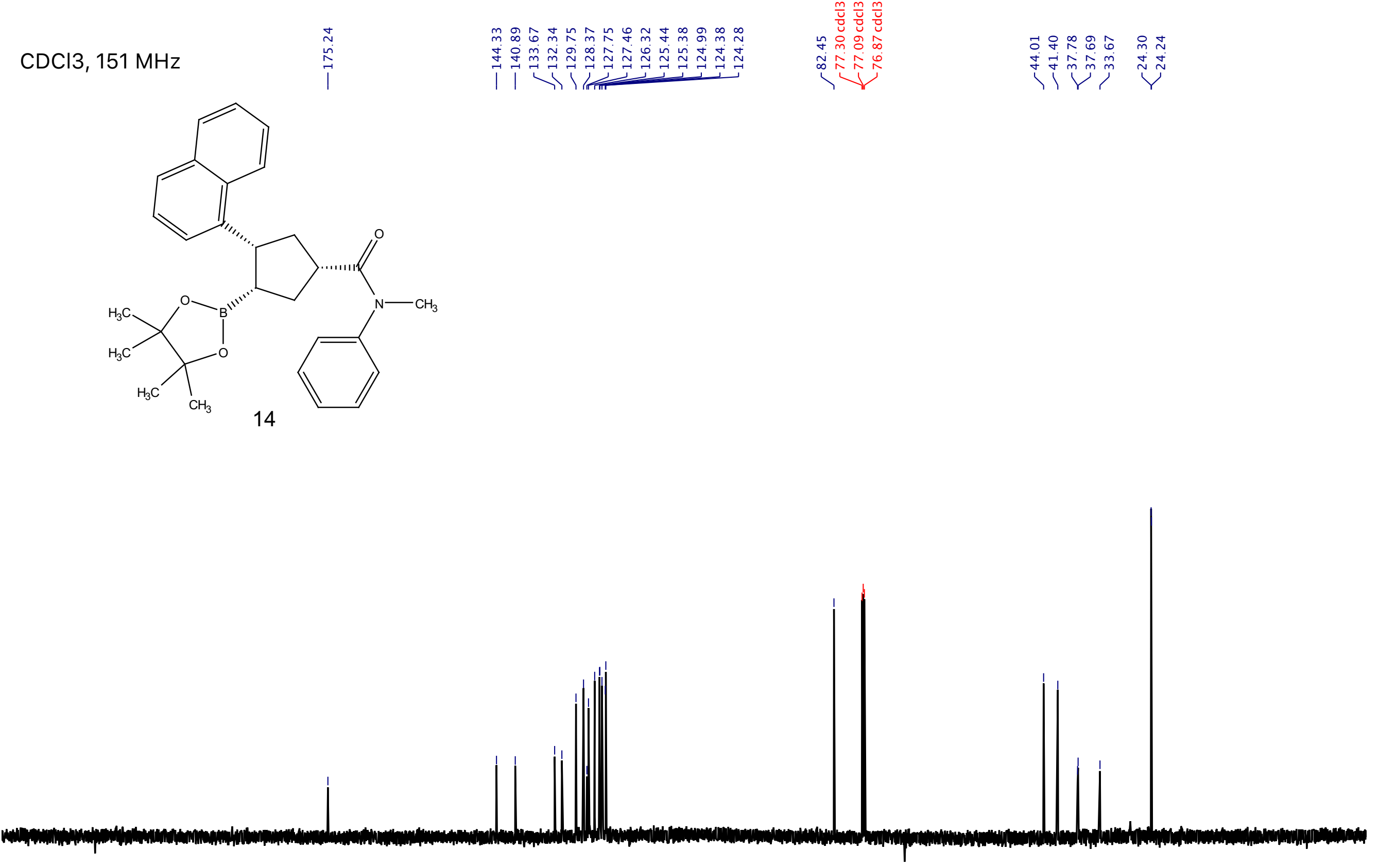

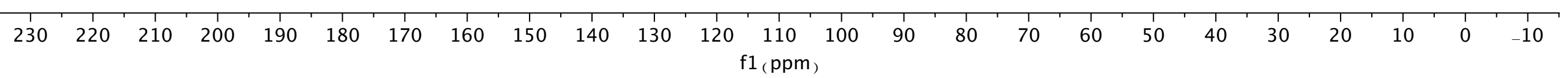


$\mathrm{CDCl} 3,600 \mathrm{MHz}$
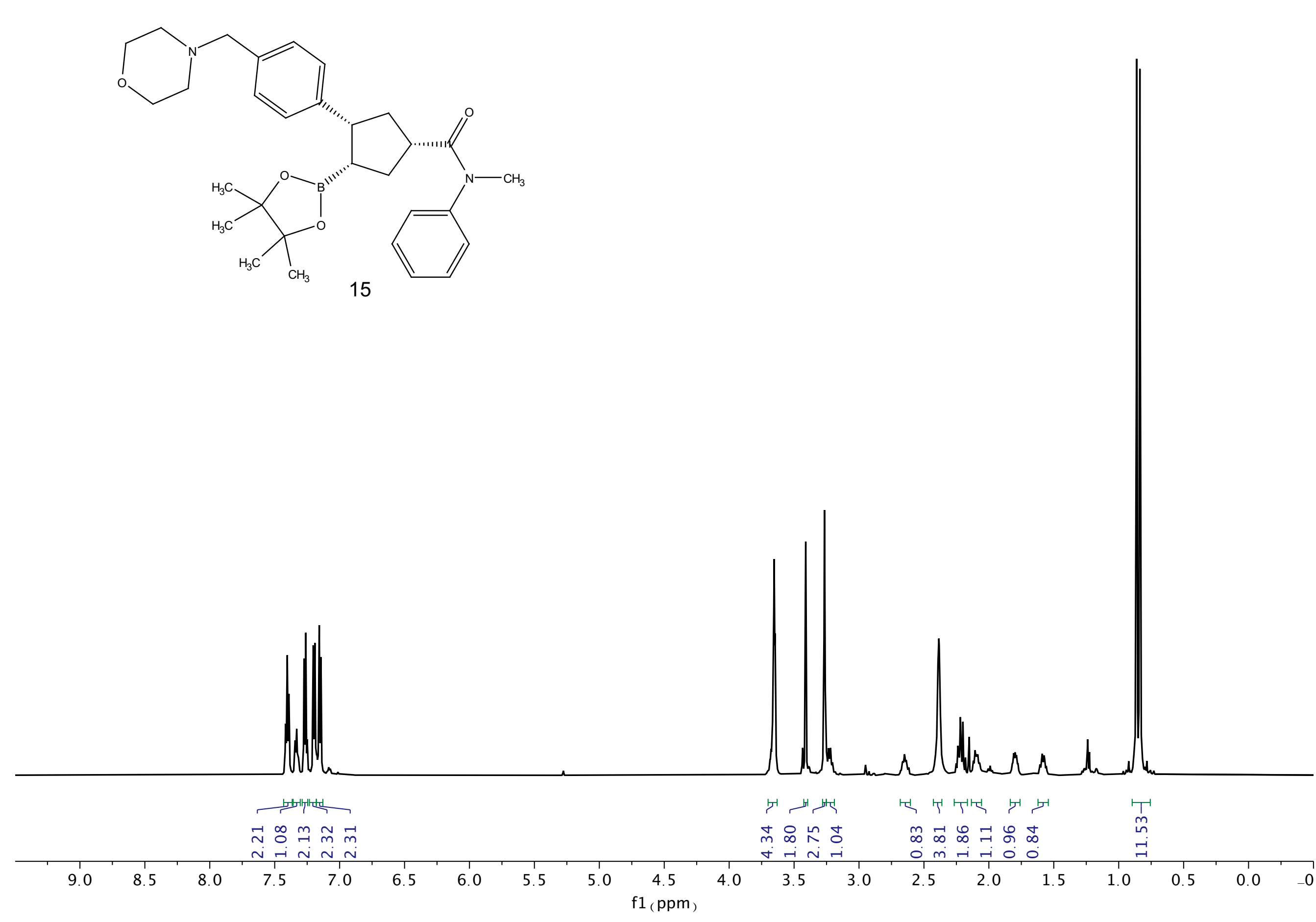


$\mathrm{CDCl}, 126 \mathrm{MHz} \quad \underbrace{n}$
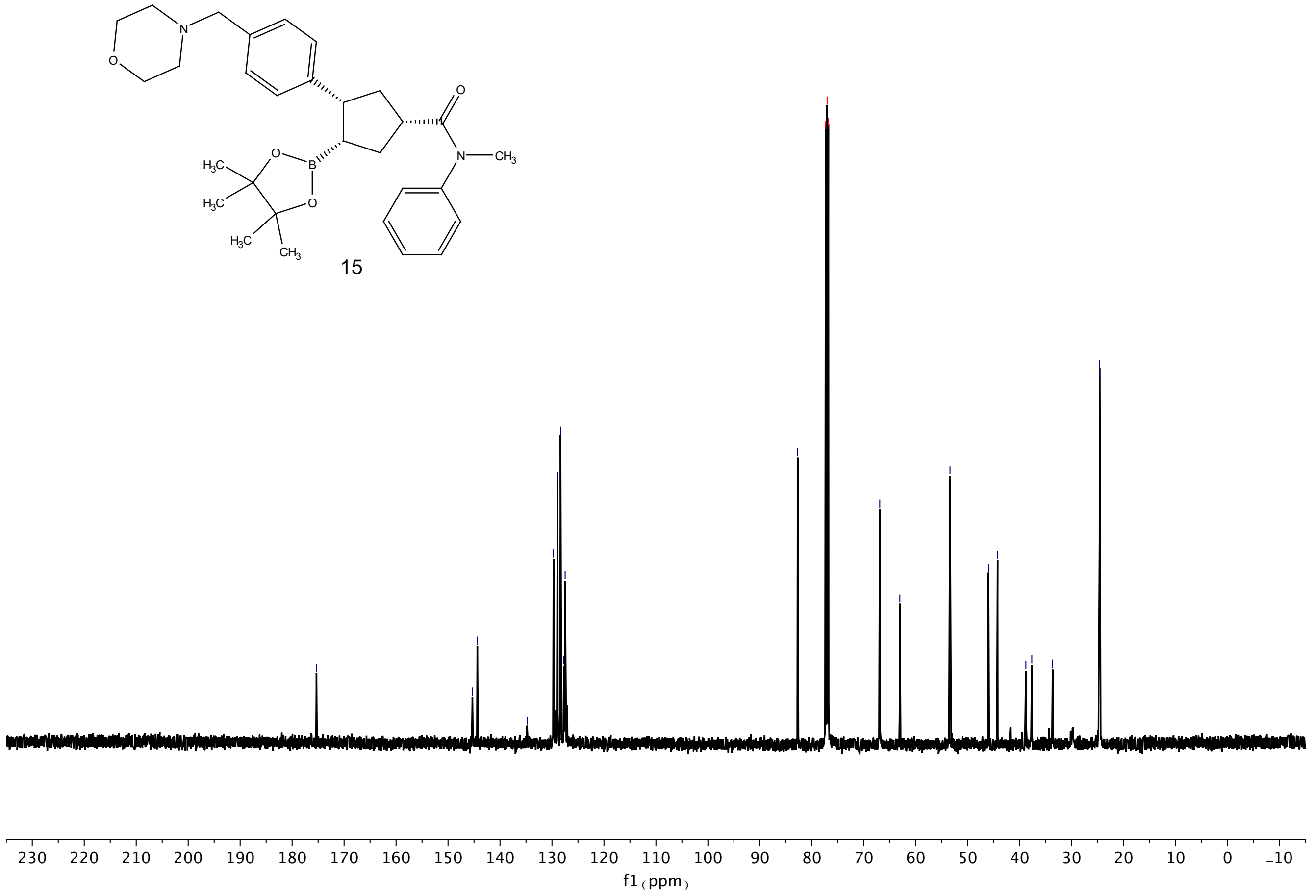
$\mathrm{CDCl} 3,600 \mathrm{MHz}$
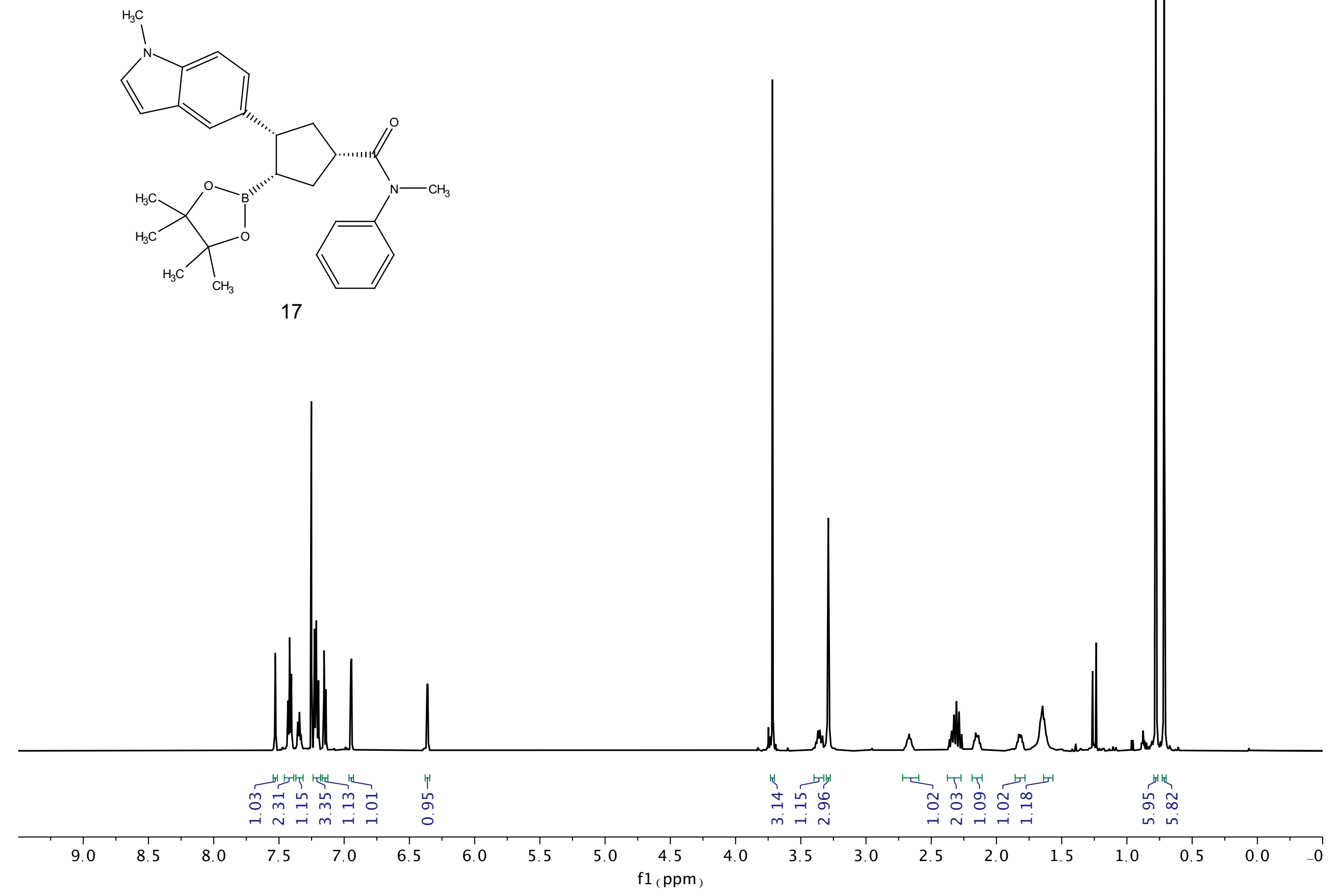


\section{$\mathrm{CDCl} 3,151 \mathrm{MHz}$}

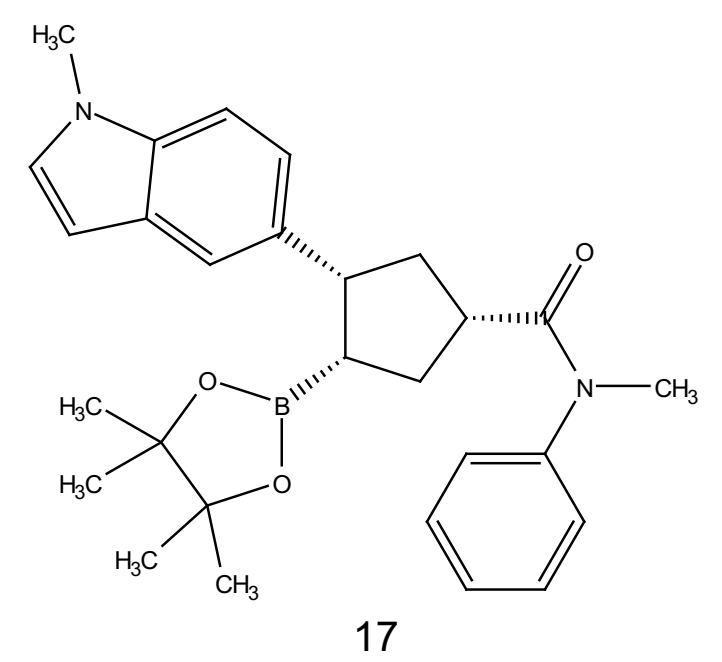

17

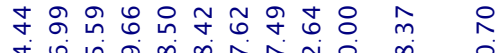

|

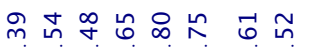

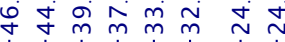

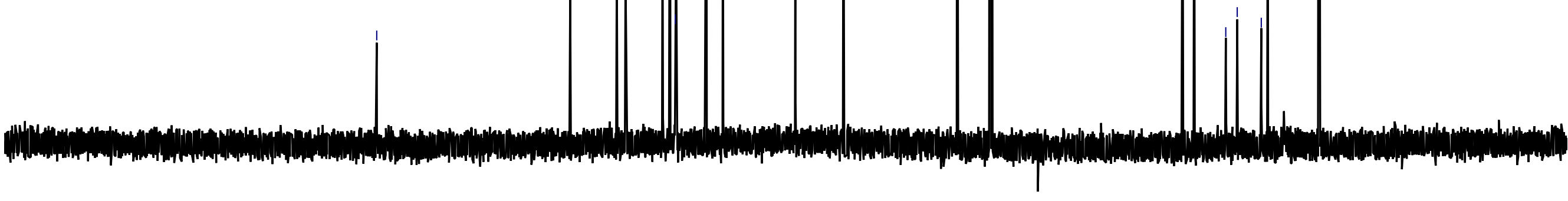



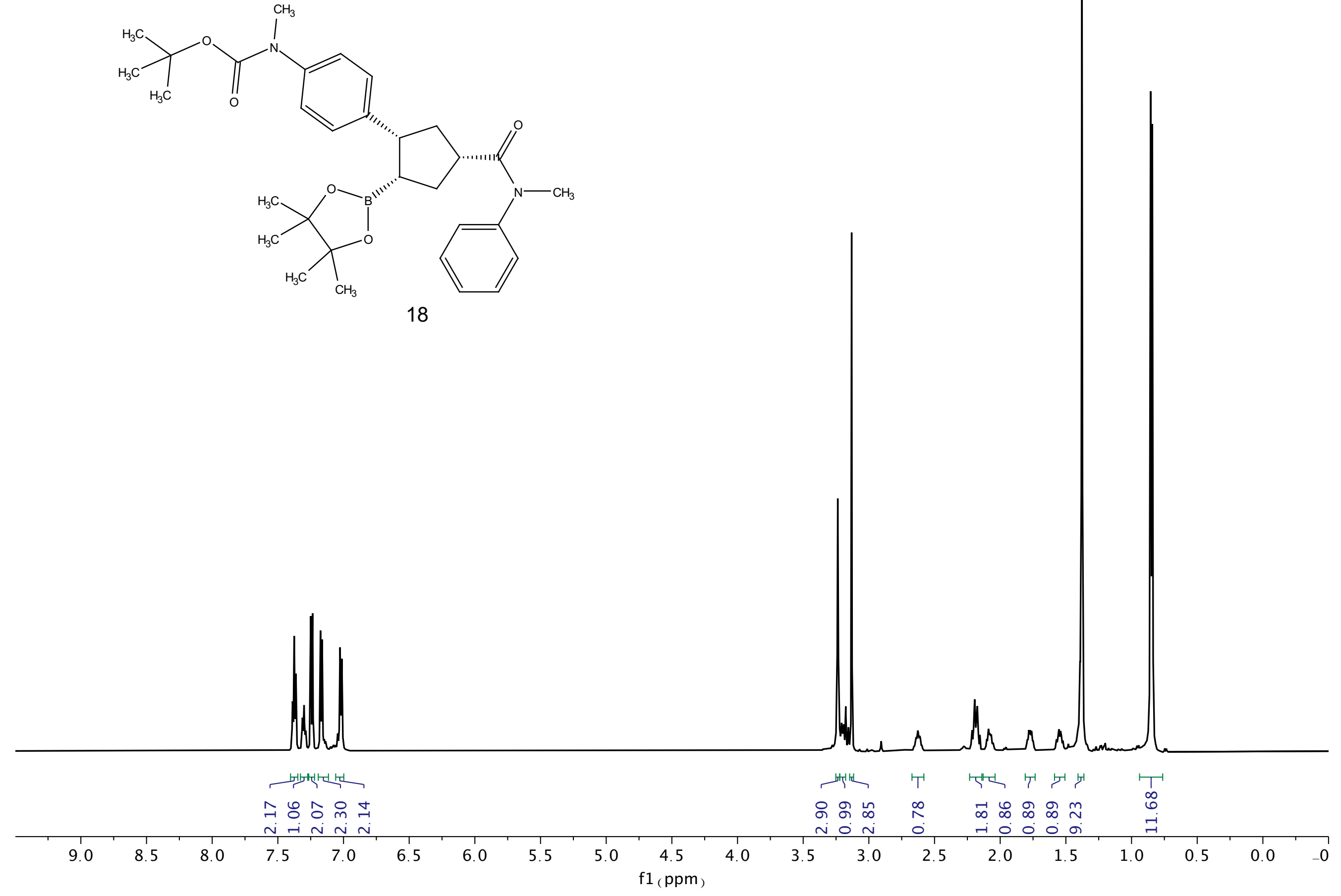


\section{$\stackrel{\circ}{\stackrel{2}{\sim}}$}

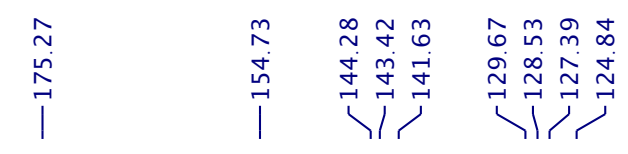

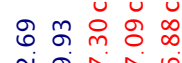

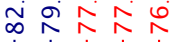

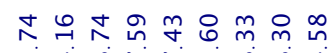

当 $\forall \dot{m} \hat{m} \hat{m} m \stackrel{m}{\sim} \stackrel{\infty}{\sim}$

CDCl3, $151 \mathrm{MHz}$

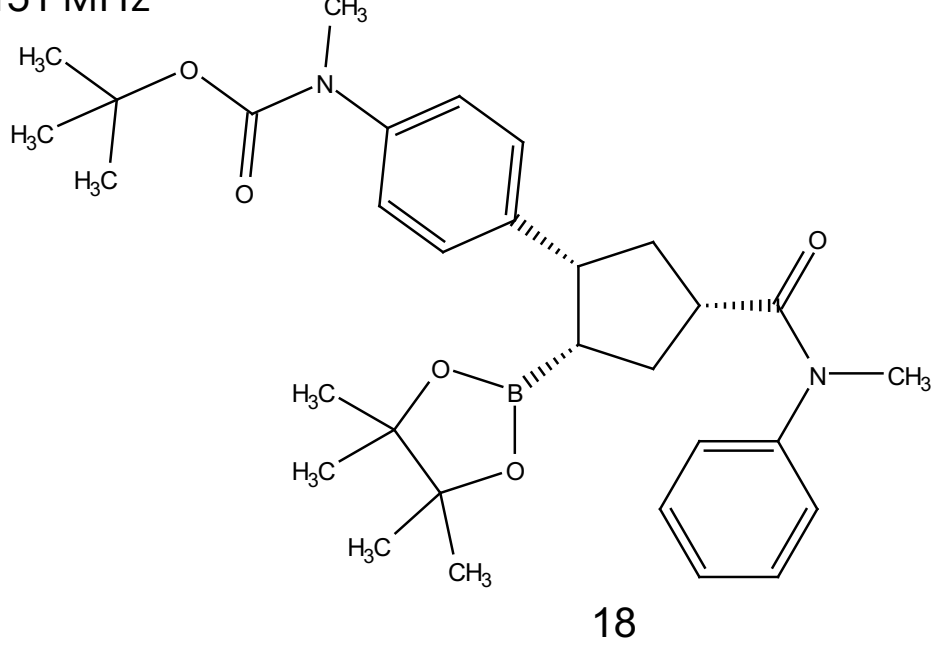

तif

لर

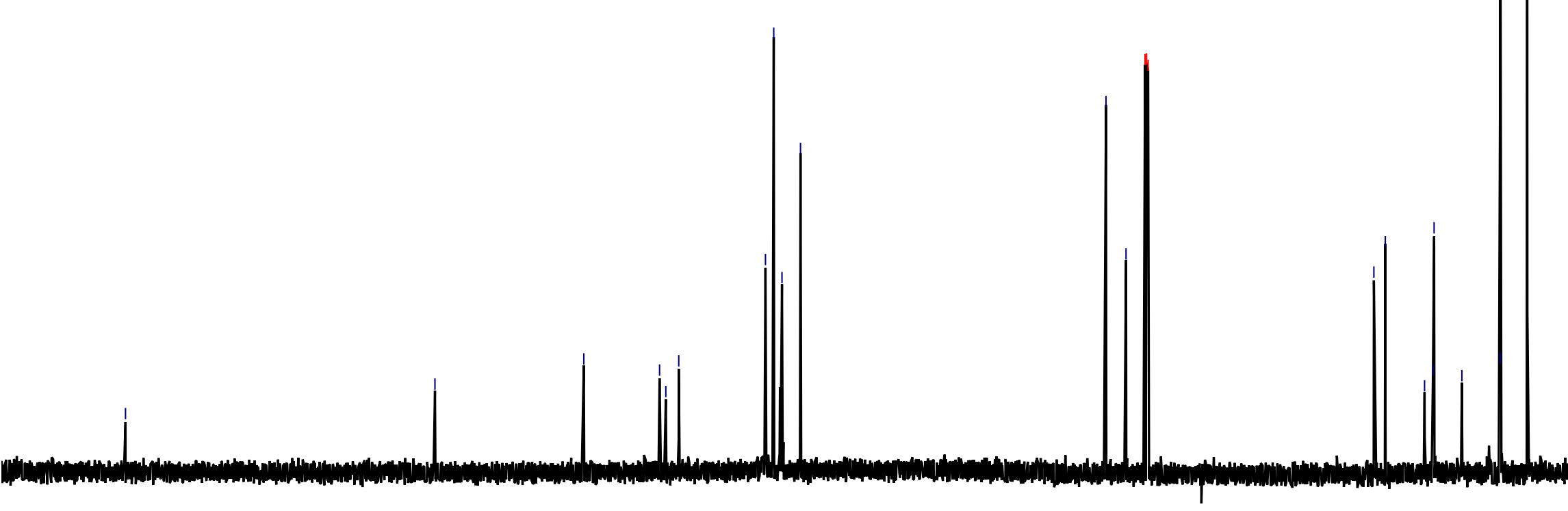




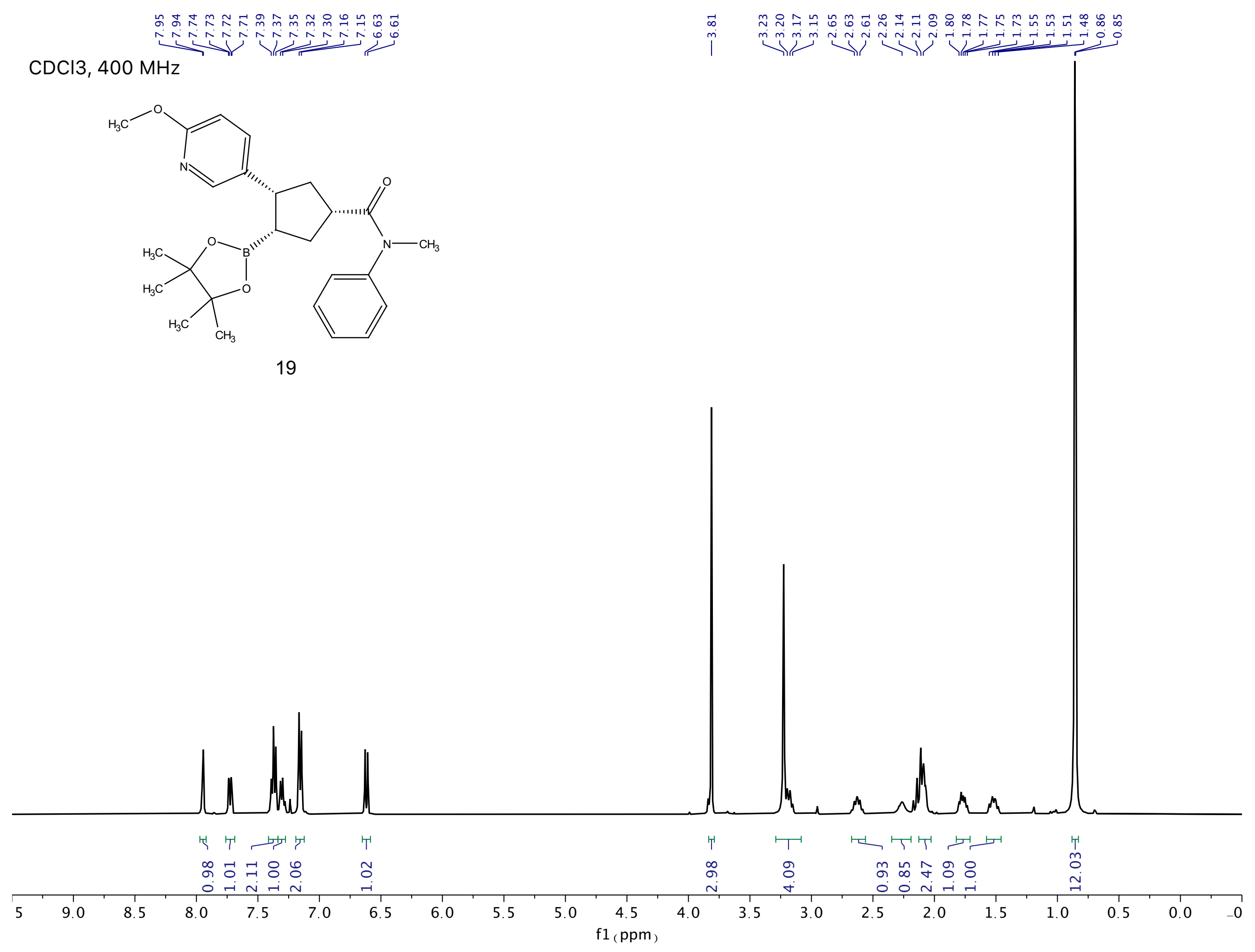




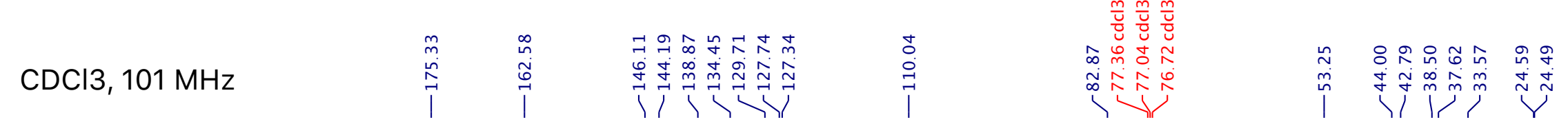

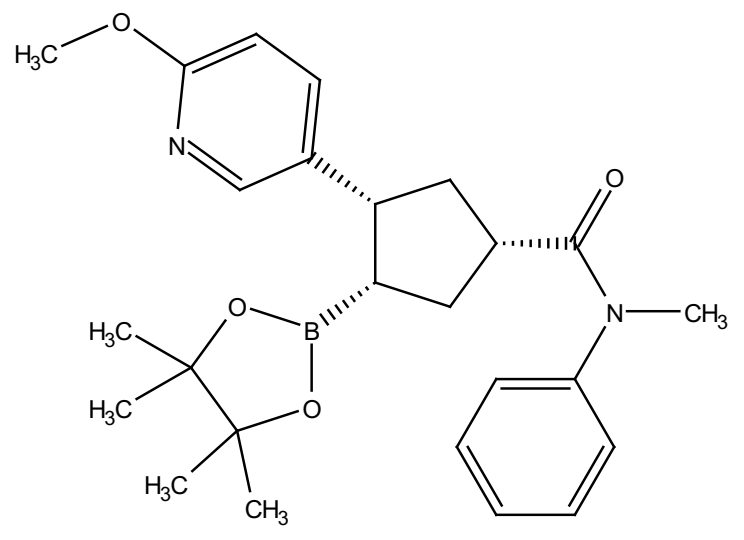

19

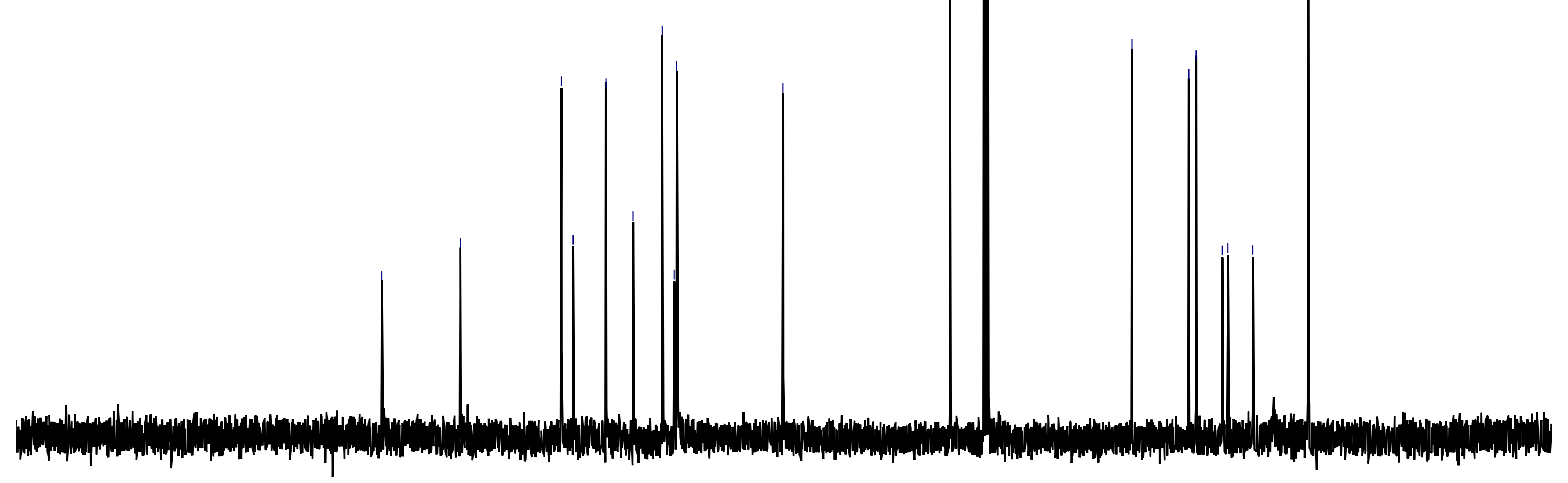

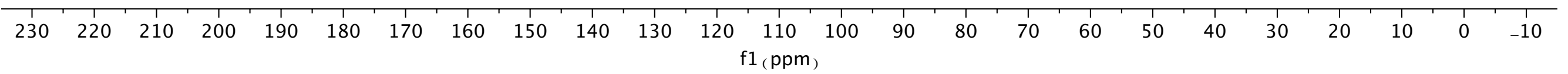


$\mathrm{CDCl} 3,600 \mathrm{MHz}$
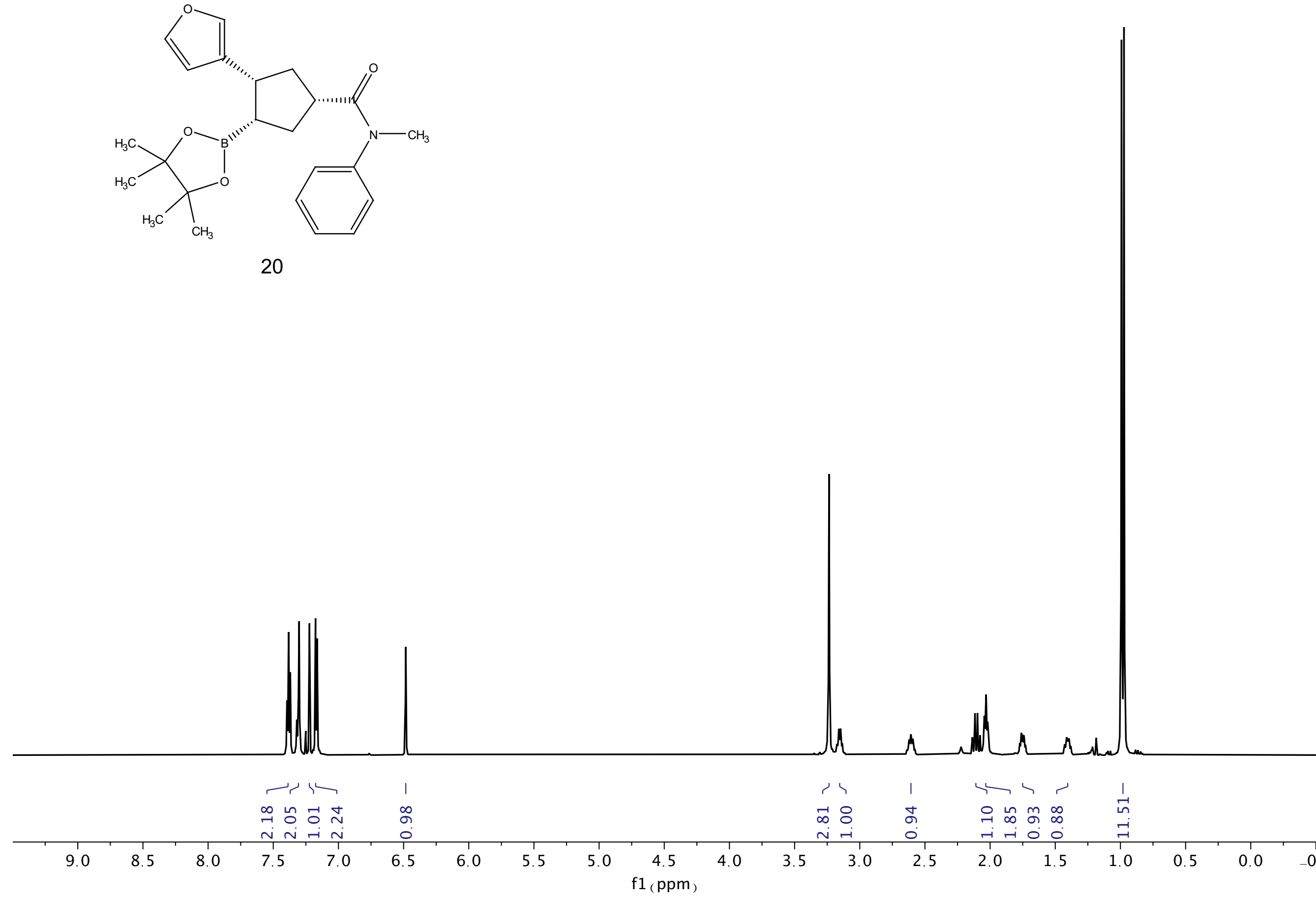


$\mathrm{CDCl}, 151 \mathrm{MHz}$

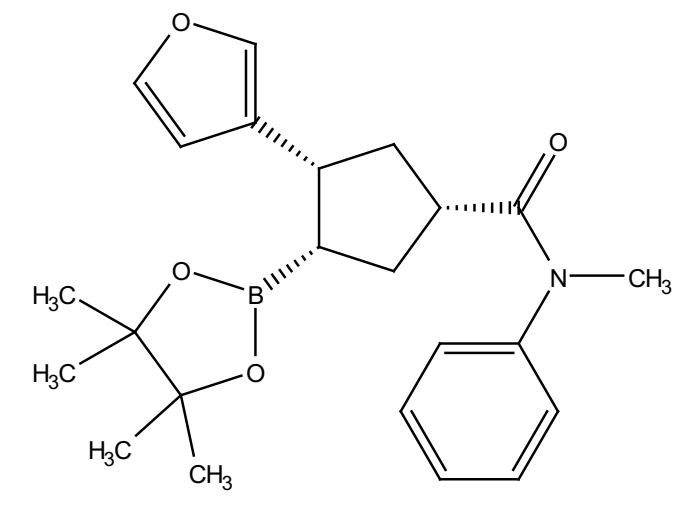

20

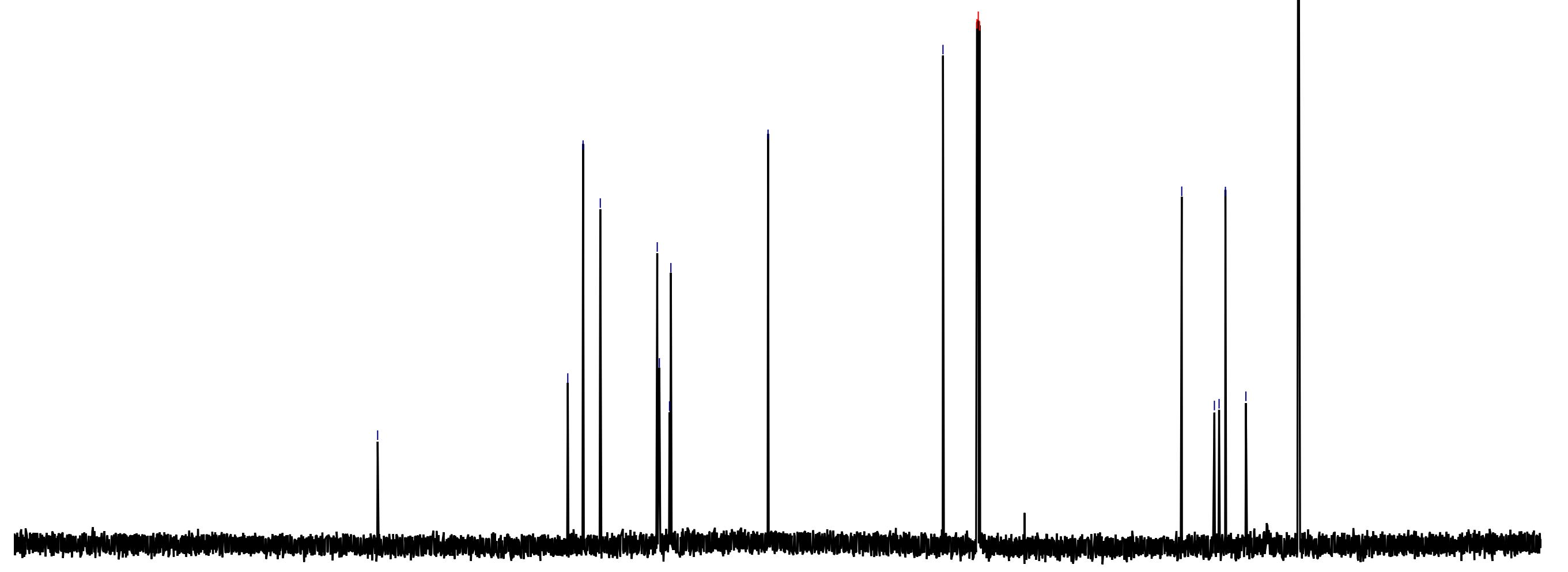



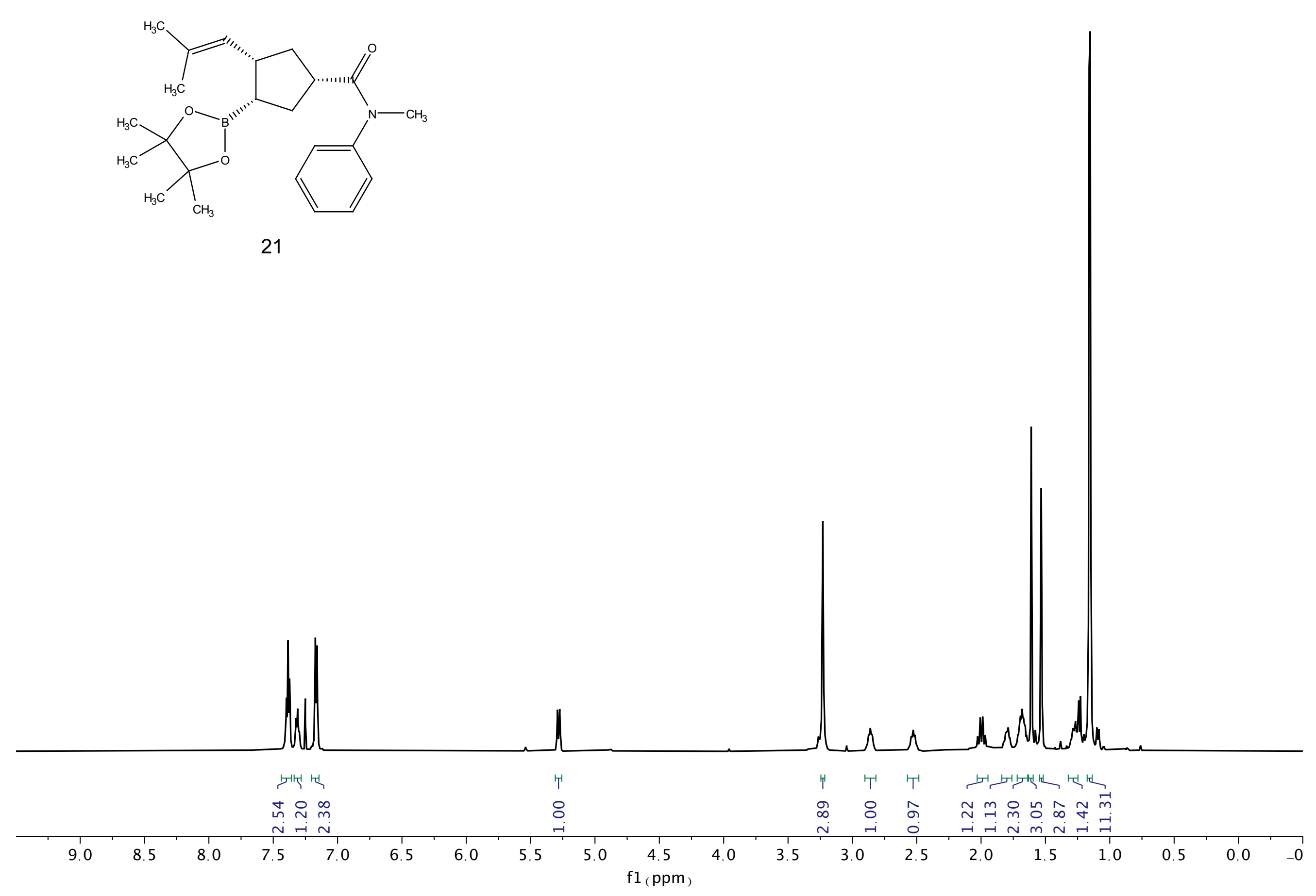

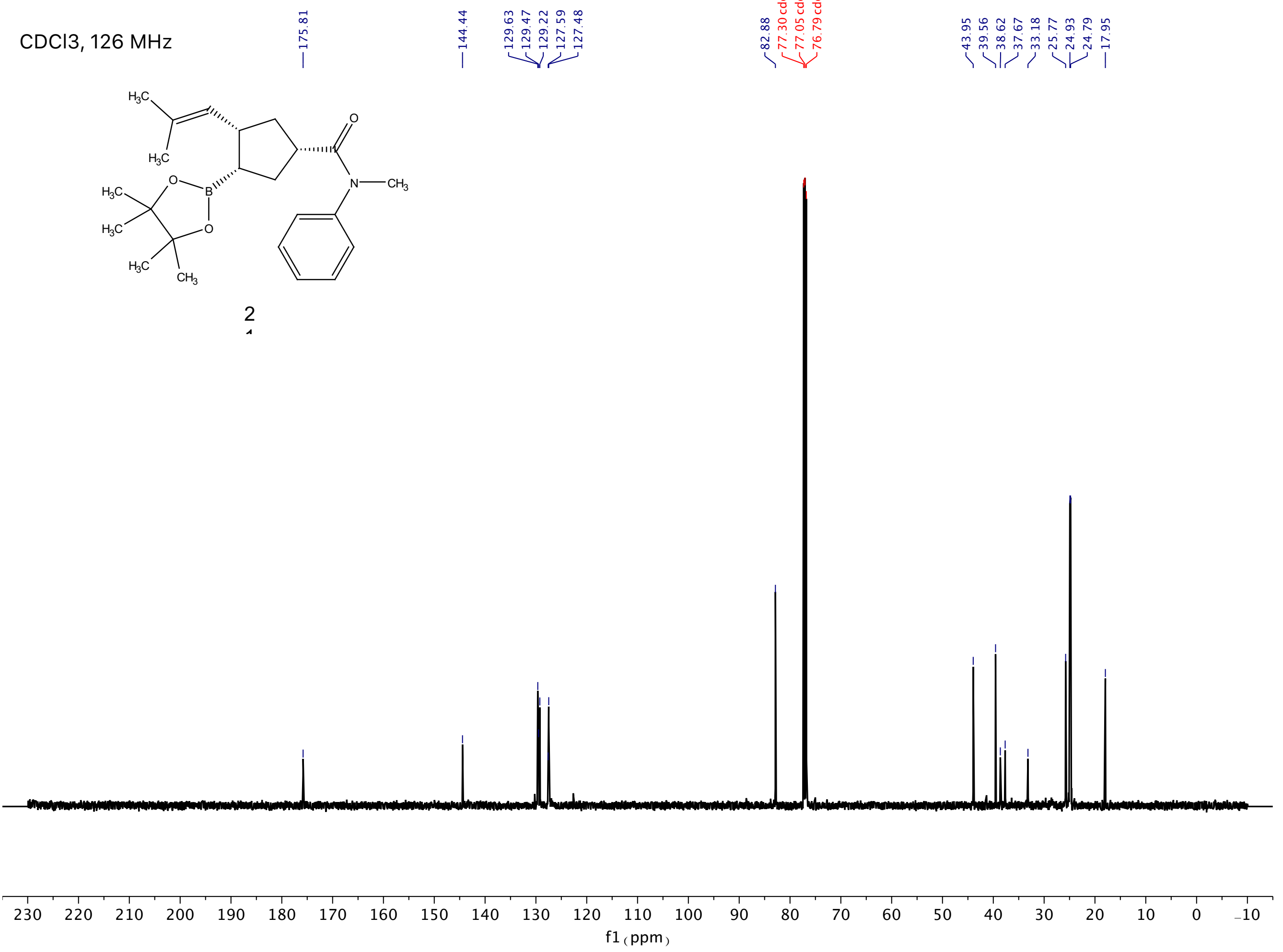
$\mathrm{CDCl} 3,400 \mathrm{MHz}$

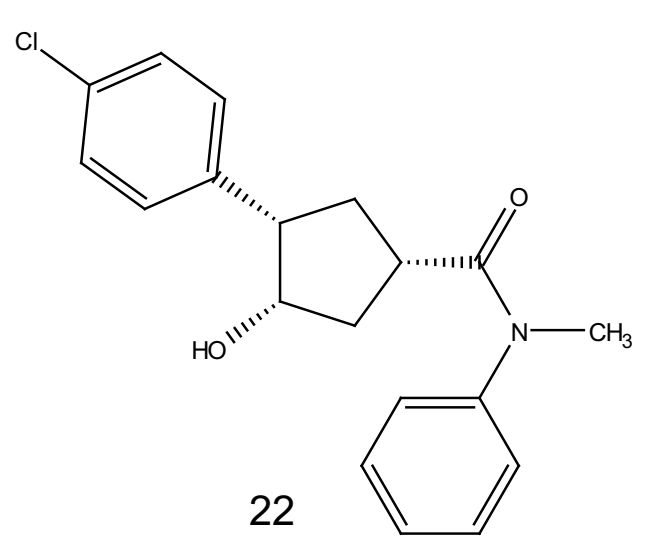

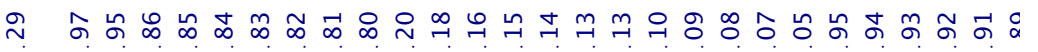

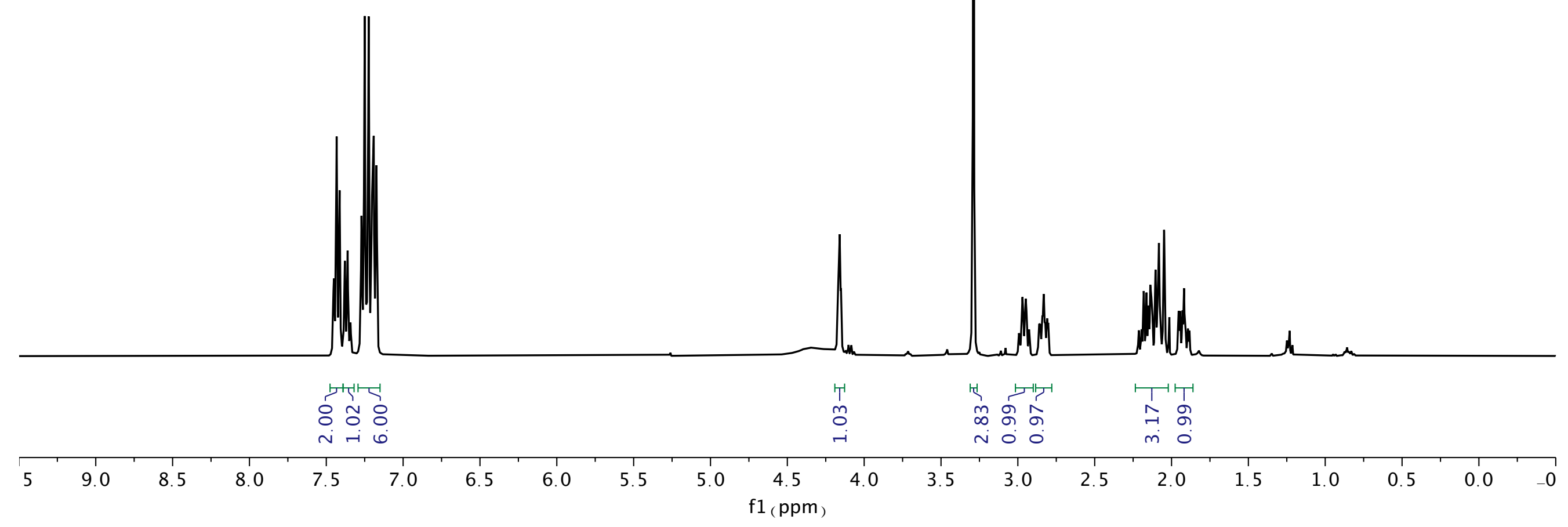



CDCl3, $101 \mathrm{MHz}$

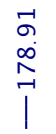

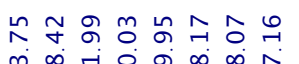

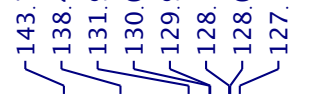
棺

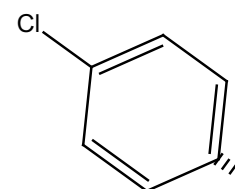

HO"
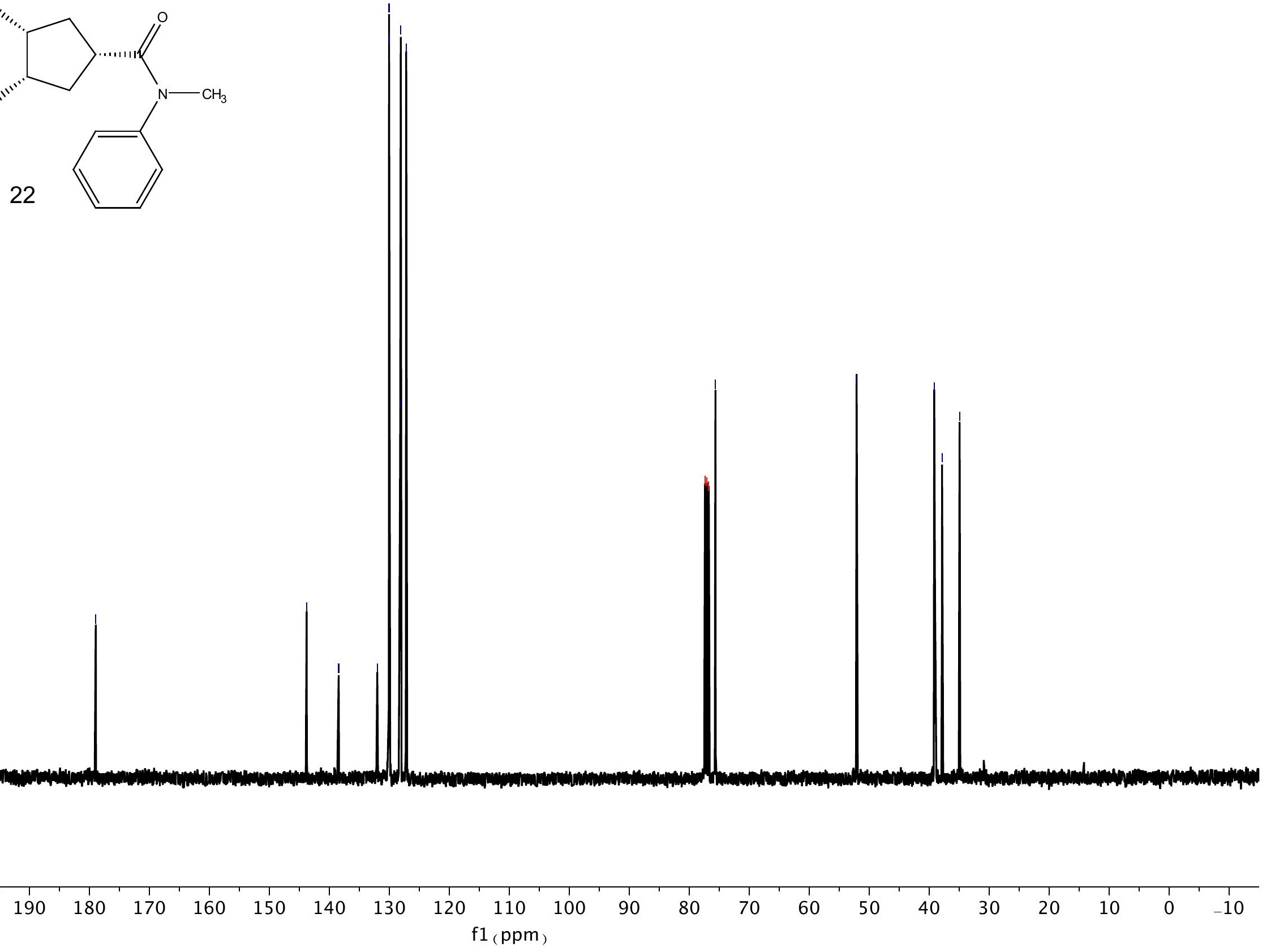

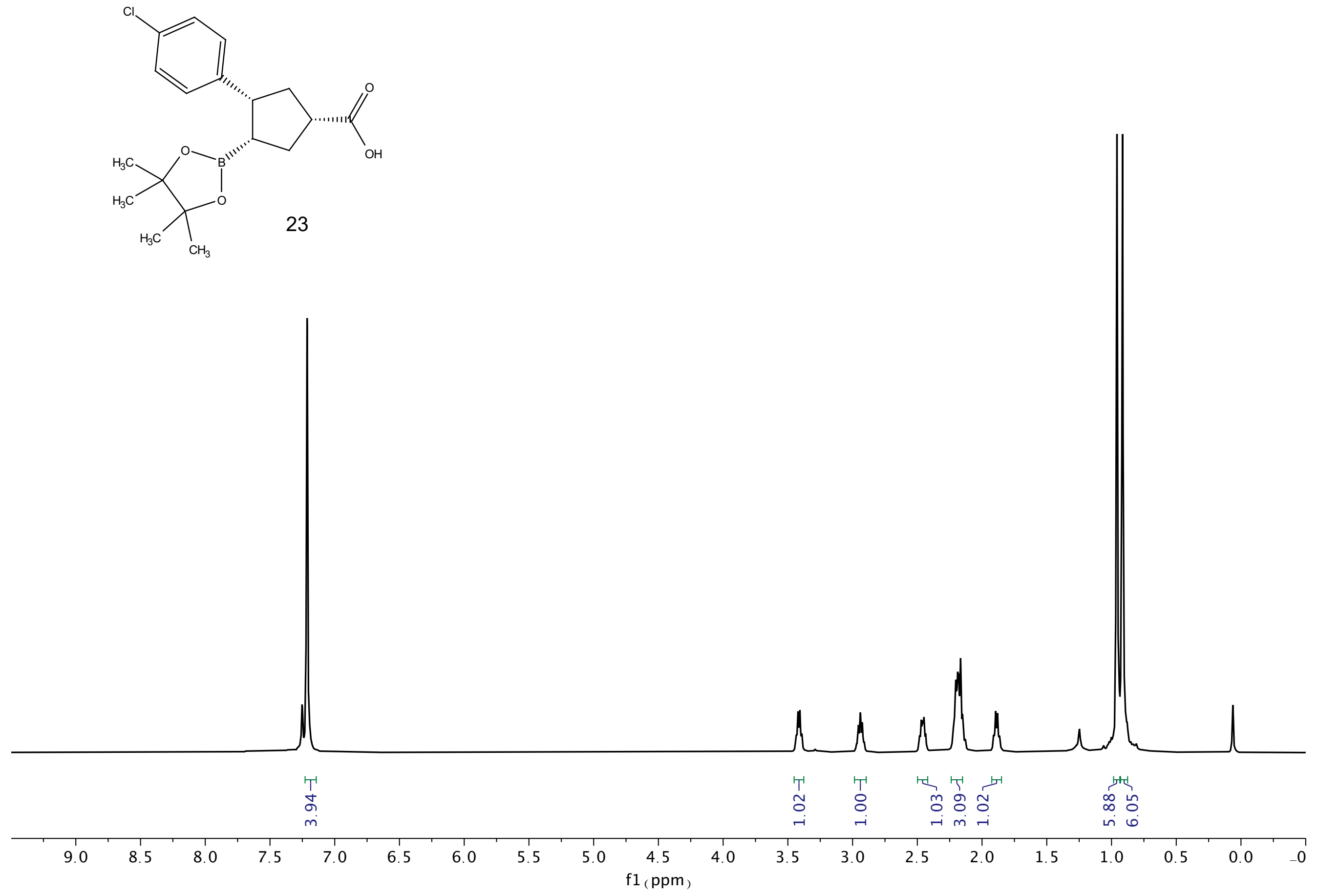


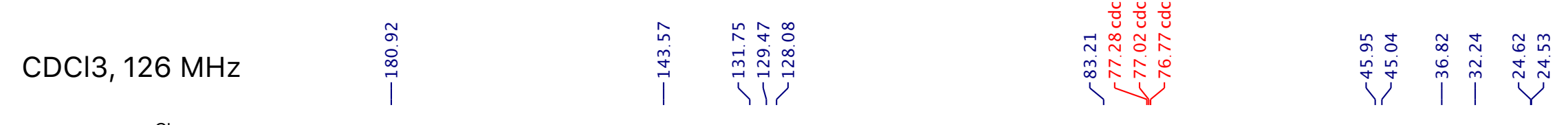
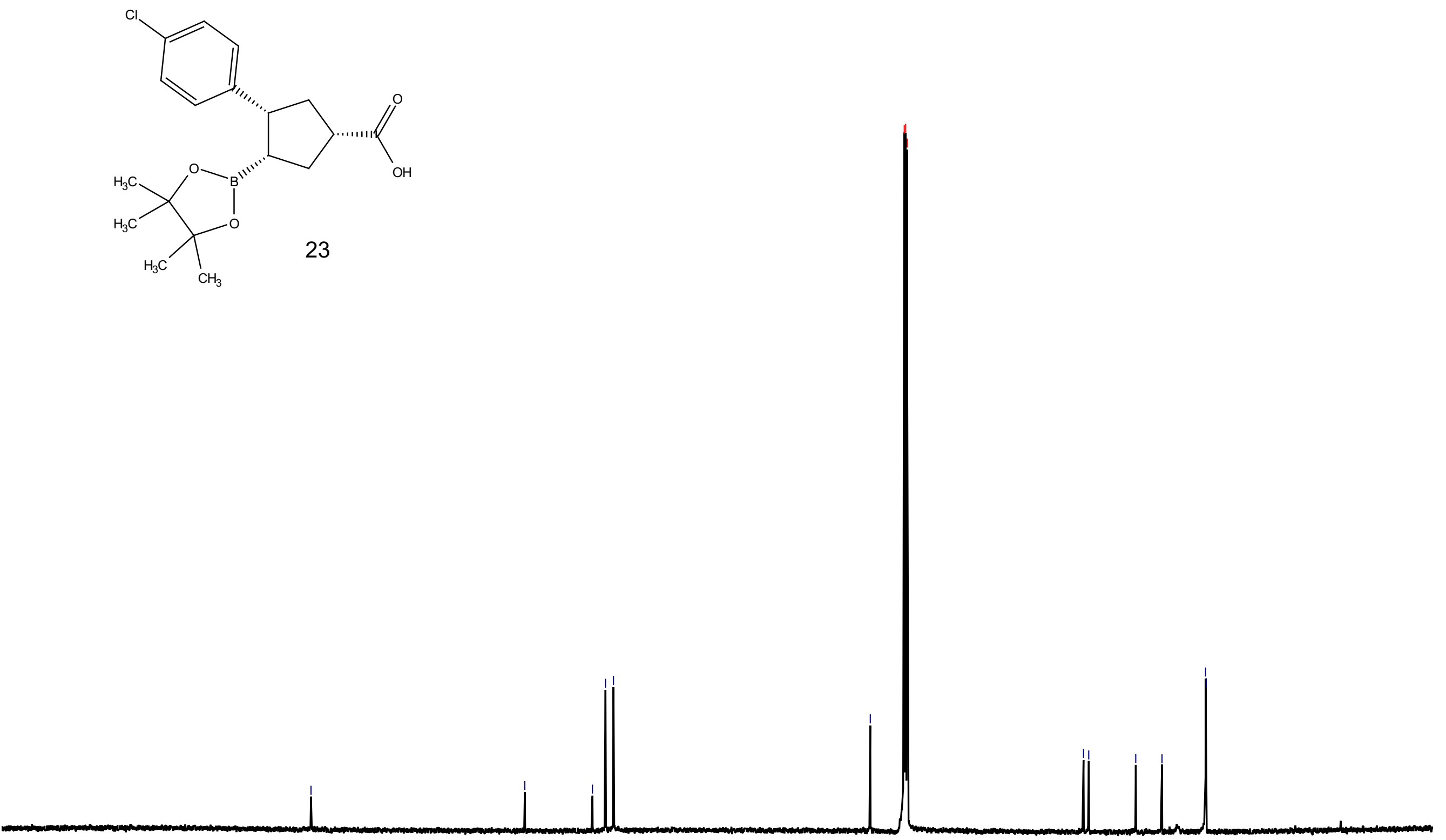

$\begin{array}{llllllllllllllllllllllllllllllllllllllllll}230 & 220 & 210 & 200 & 190 & 180 & 170 & 160 & 150 & 140 & 130 & 120 & 110 & 100 & 90 & 80 & 70 & 60 & 50 & 40 & 30 & 20 & 10 & 0 & -10 & \end{array}$



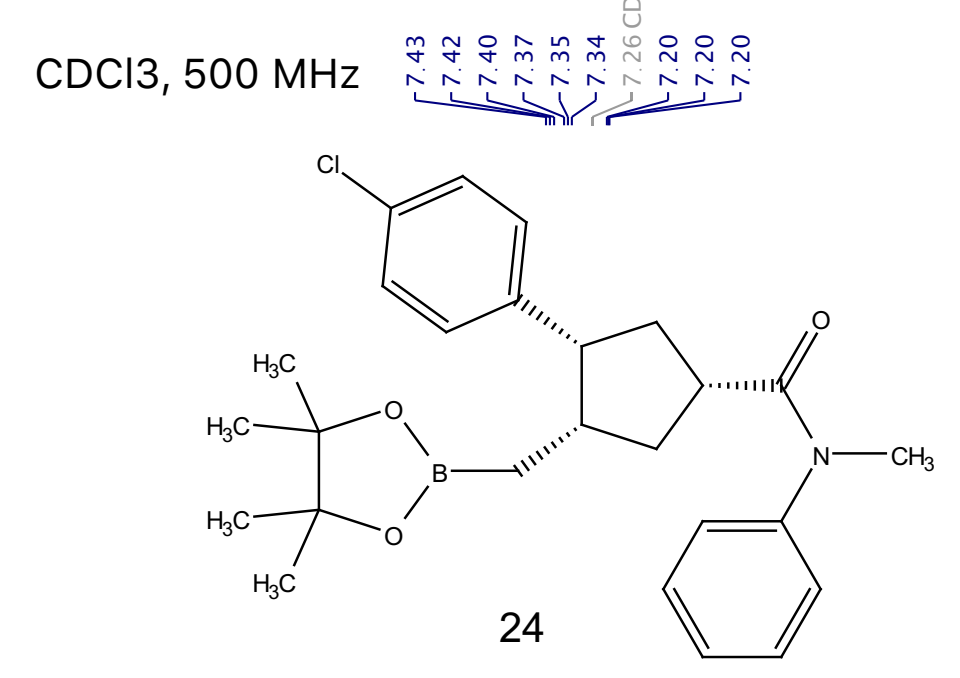

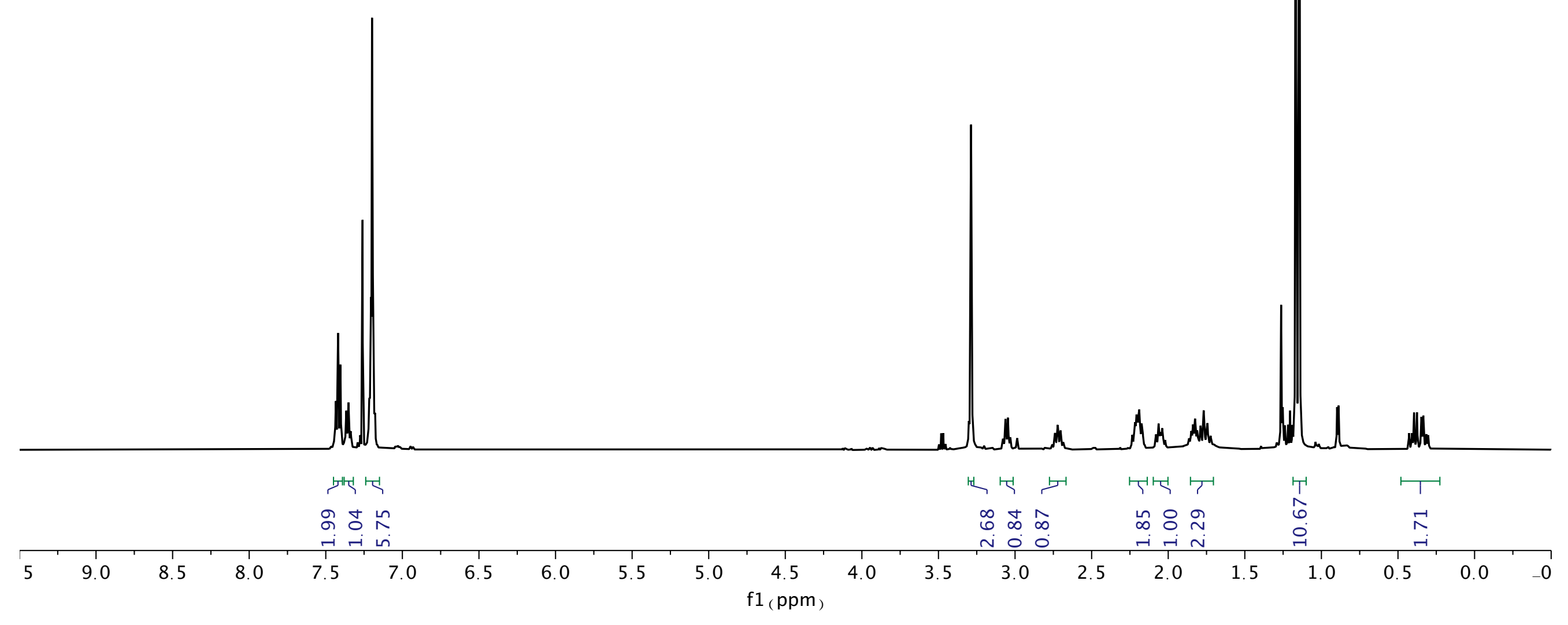




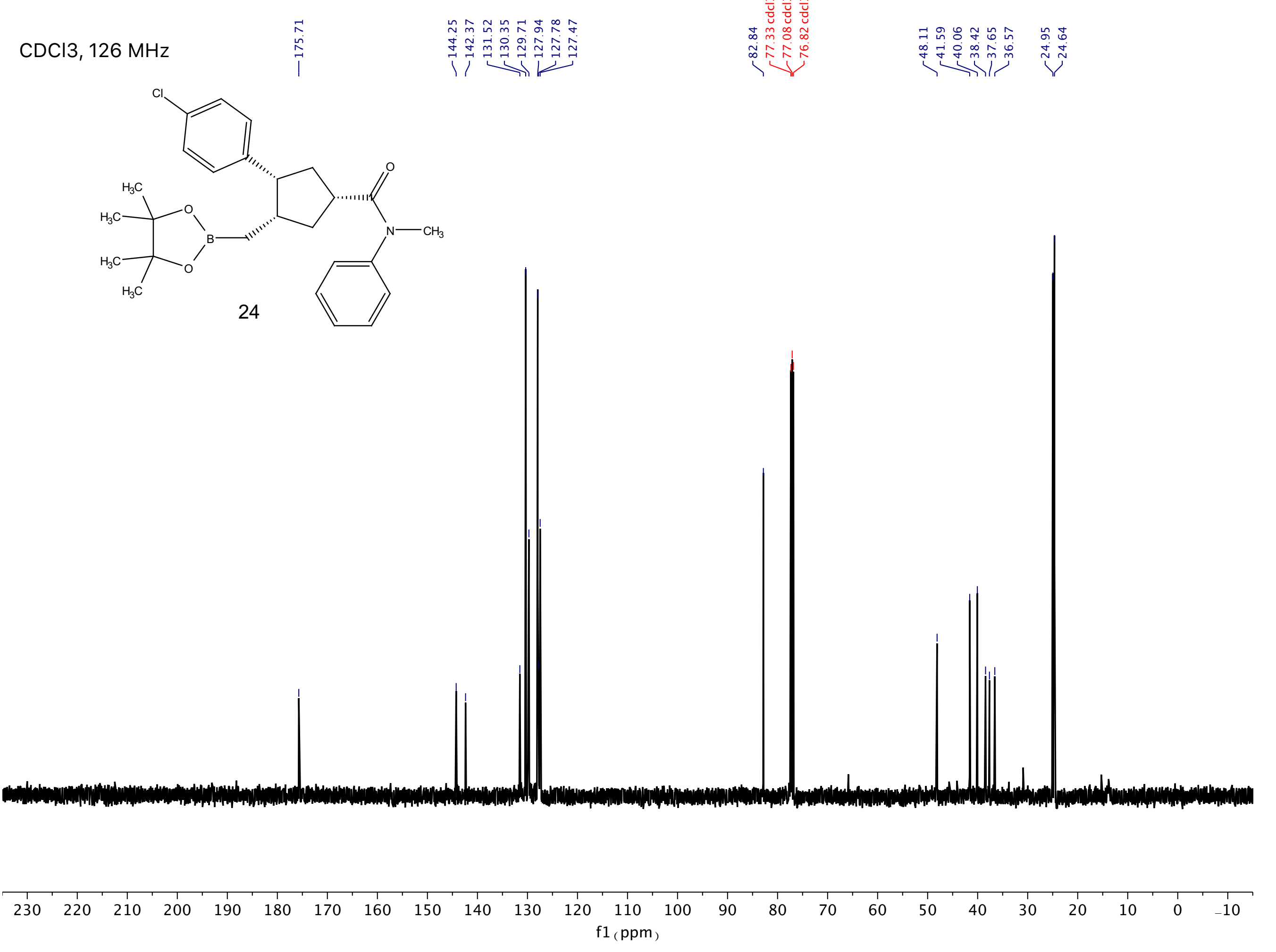



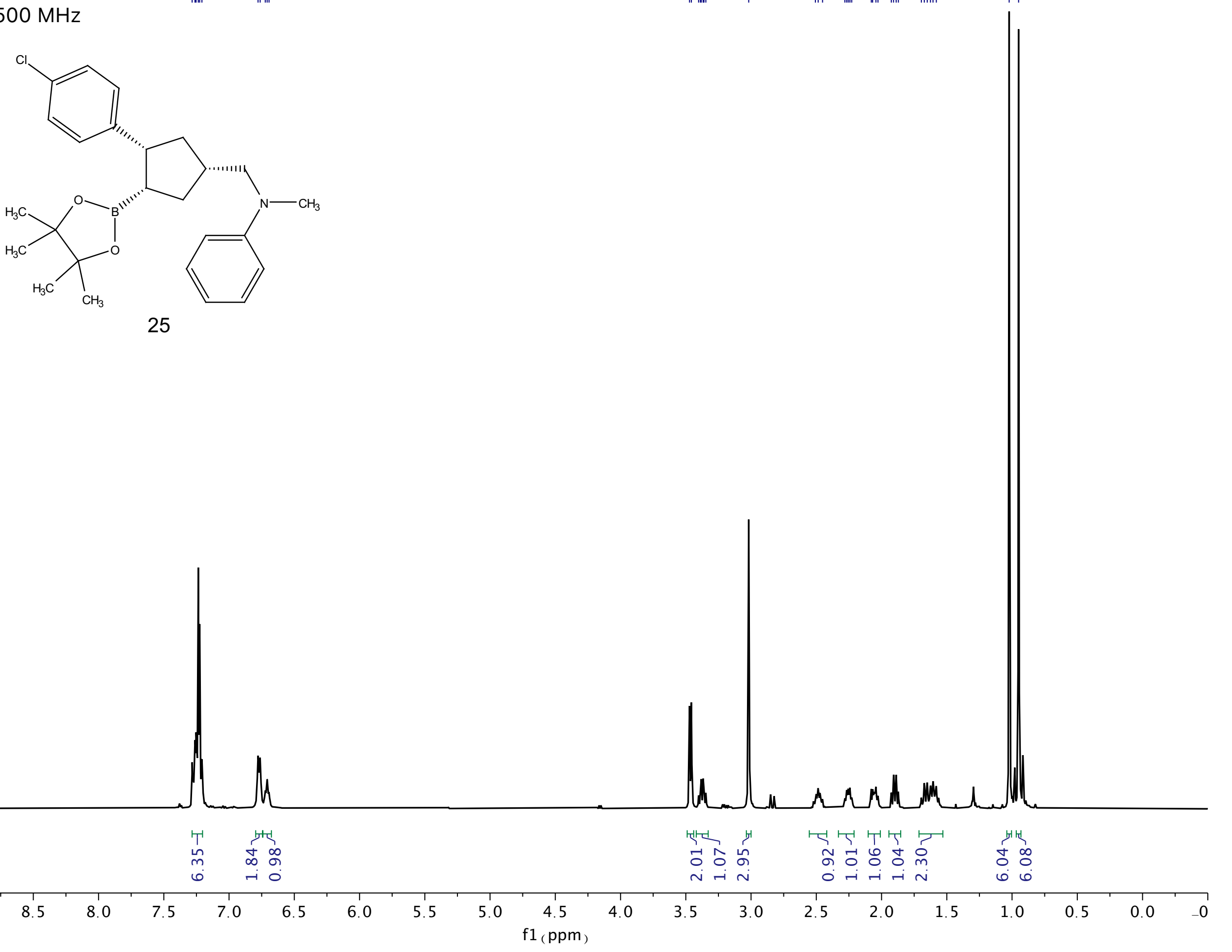


\section{$\mathrm{CDCl} 3,126 \mathrm{MHz}$}

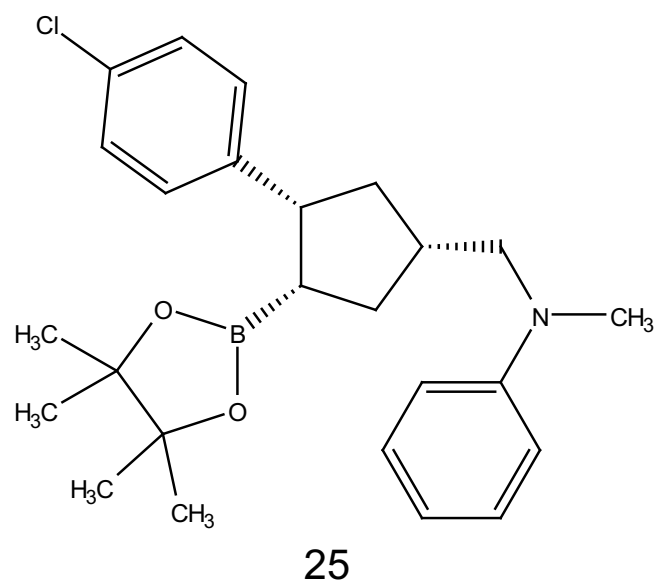

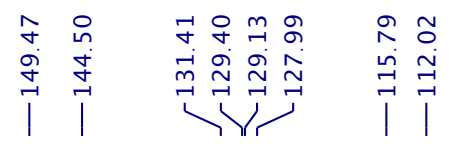

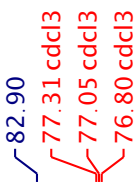

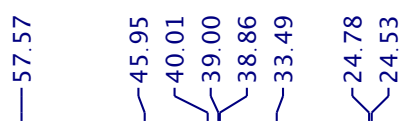



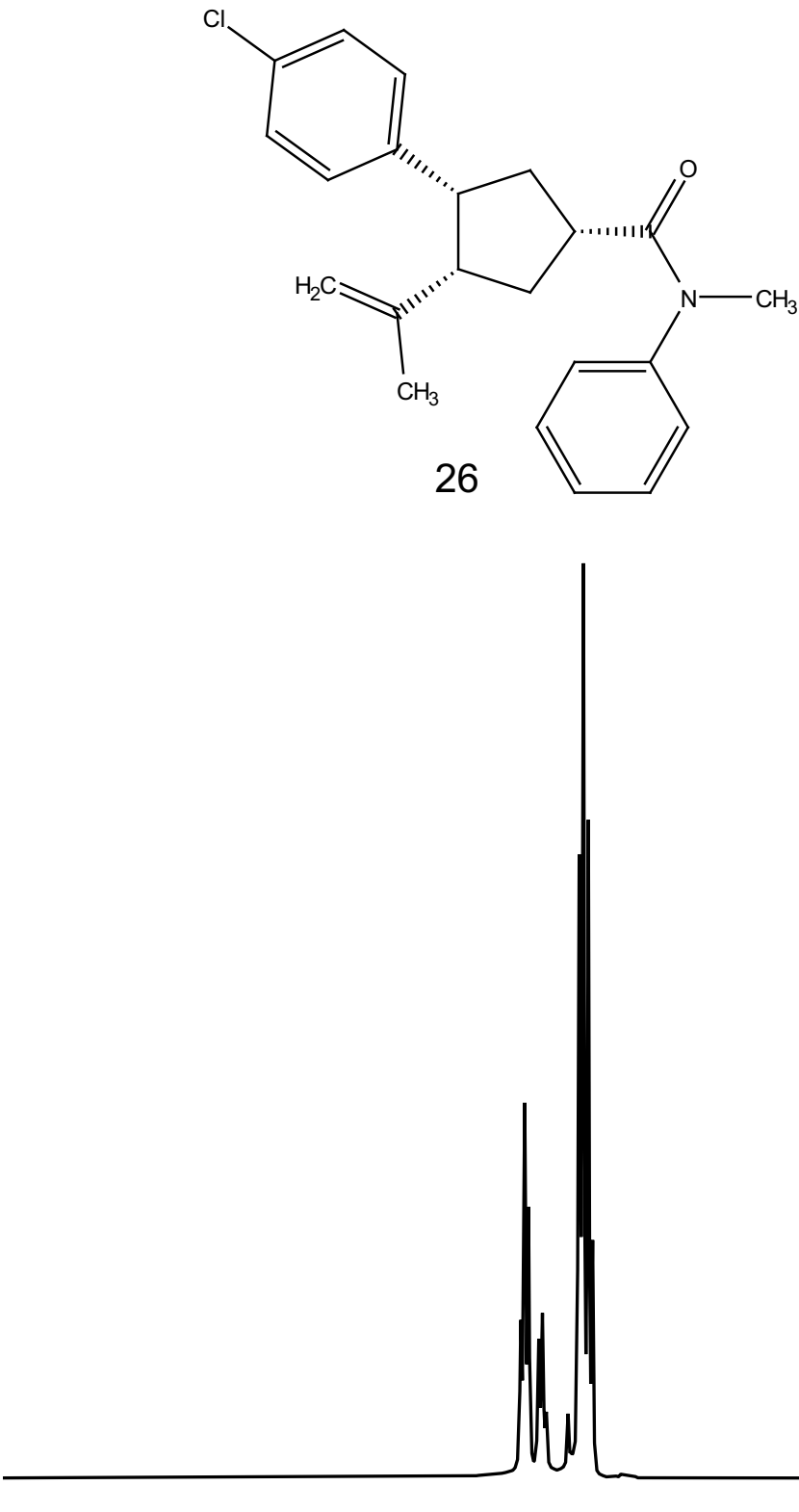

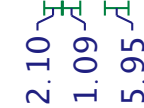

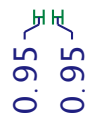

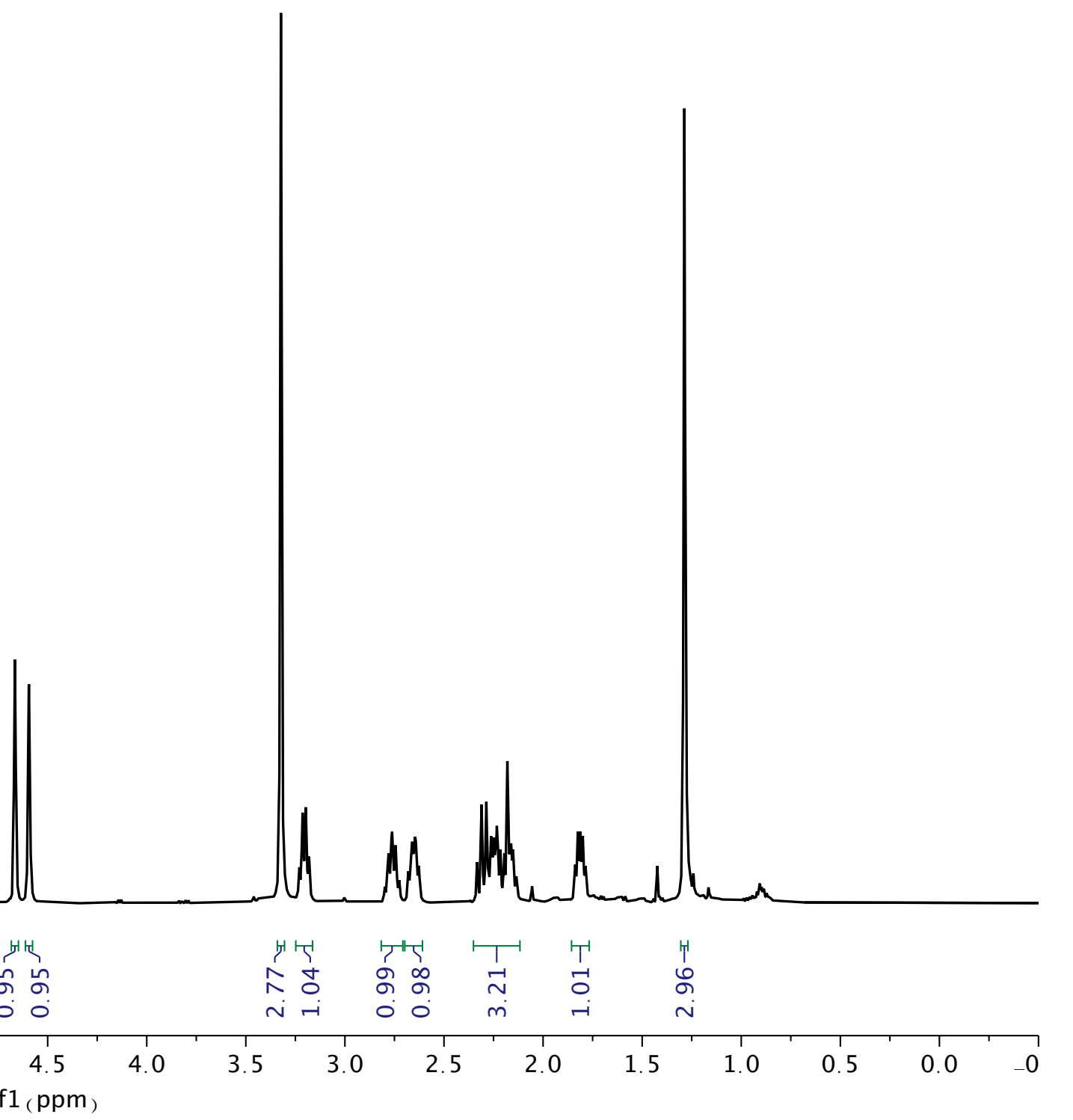




$\mathrm{CDCl}, 126 \mathrm{MHz}$
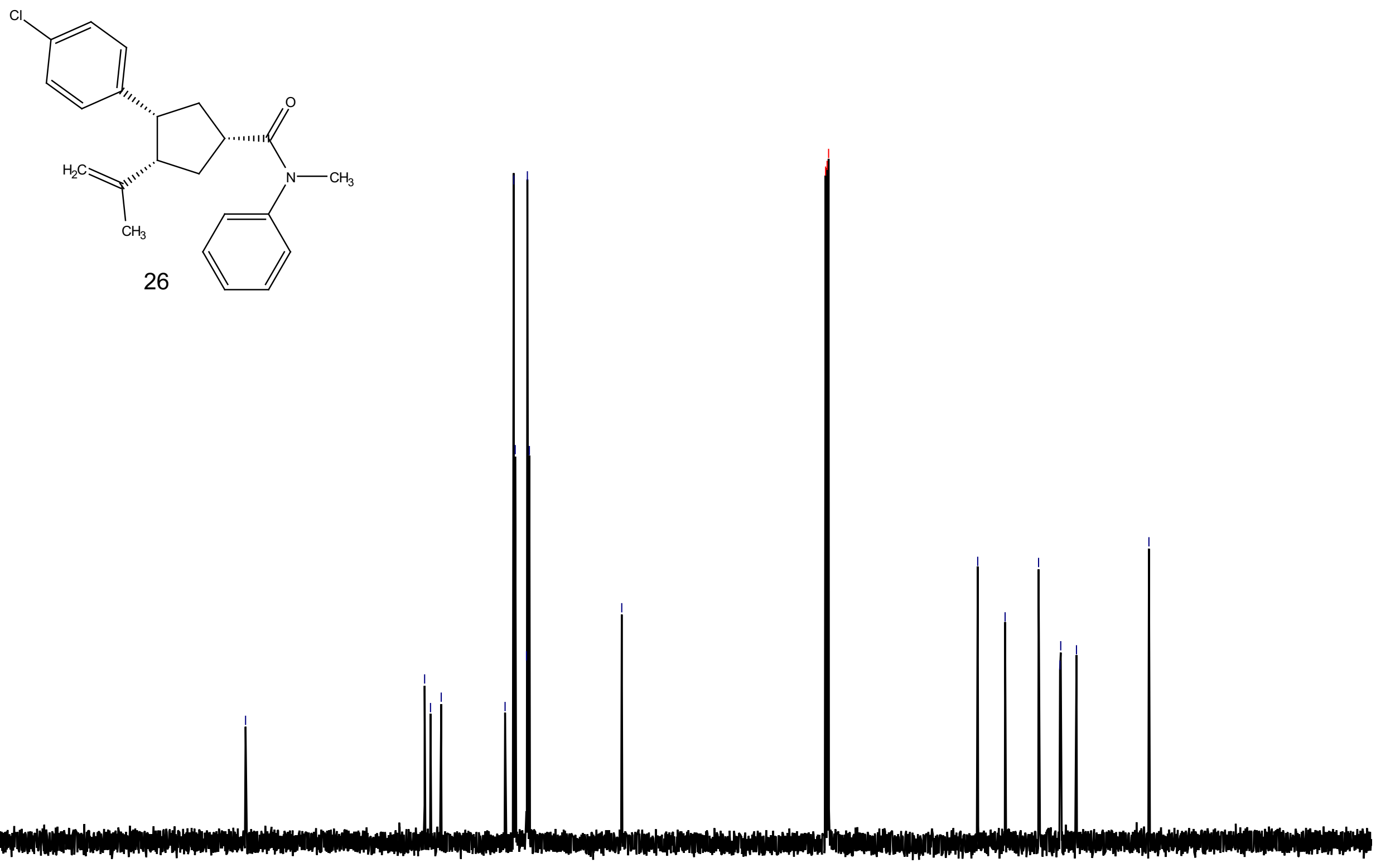

\begin{tabular}{|c|c|c|c|c|c|c|c|c|c|c|c|c|c|c|c|c|c|c|c|c|c|c|c|c|}
\hline 230 & 220 & 210 & 200 & 190 & 180 & 170 & 160 & 150 & 140 & 130 & 120 & 110 & 100 & 90 & 80 & 70 & 60 & 50 & 40 & 30 & 20 & 10 & 0 & -10 \\
\hline
\end{tabular}

